\title{
Beoordelingen van processen : professional judgment of judgment van een professional
}

Citation for published version (APA):

Verkruijsse, J. P. J. (2005). Beoordelingen van processen : professional judgment of judgment van een professional. [Doctoral Thesis, Maastricht University]. Universitaire Pers Maastricht. https://doi.org/10.26481/dis.20051118jv

Document status and date:

Published: 01/01/2005

DOI:

10.26481/dis.20051118jv

Document Version:

Publisher's PDF, also known as Version of record

\section{Please check the document version of this publication:}

- A submitted manuscript is the version of the article upon submission and before peer-review. There can be important differences between the submitted version and the official published version of record.

People interested in the research are advised to contact the author for the final version of the publication, or visit the DOI to the publisher's website.

- The final author version and the galley proof are versions of the publication after peer review.

- The final published version features the final layout of the paper including the volume, issue and page numbers.

Link to publication

\footnotetext{
General rights rights.

- You may freely distribute the URL identifying the publication in the public portal. please follow below link for the End User Agreement:

www.umlib.nl/taverne-license

Take down policy

If you believe that this document breaches copyright please contact us at:

repository@maastrichtuniversity.nl

providing details and we will investigate your claim.
}

Copyright and moral rights for the publications made accessible in the public portal are retained by the authors and/or other copyright owners and it is a condition of accessing publications that users recognise and abide by the legal requirements associated with these

- Users may download and print one copy of any publication from the public portal for the purpose of private study or research.

- You may not further distribute the material or use it for any profit-making activity or commercial gain

If the publication is distributed under the terms of Article $25 \mathrm{fa}$ of the Dutch Copyright Act, indicated by the "Taverne" license above, 
Beoordeling van processen professional judgment of judgment van een professional 
Copyright (O JPJ Verkruijsse, Maastricht 2005

ISBN 9052784906

Layout en druk: Datawyse / Universitaire Pers Mastricht Omslagontwerp: Joyce Verkruijsse 


\title{
Beoordeling van processen professional judgment of judgment van een professional
}

\author{
PROEFSCHRIFT \\ ter verkrijging van de graad van doctor \\ aan de Universiteit Maastricht, \\ op gezag van de Rector Magnificus, \\ Prof. mr. G.P.M.F. Mols \\ volgens het besluit van het College van Decanen, \\ in het openbaar te verdedigen \\ op vrijdag 18 november 2005 om 14.00 uur \\ door \\ J.P.J. Verkruijsse
}

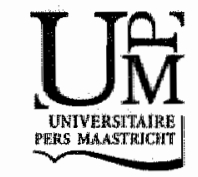




\section{Promotoren}

Prof. dr. R.J.M. Dassen RA

Prof. dr. E.H.J. Vaassen RA

\section{Beoordelingscommissie}

Prof. dr. R.H.G. Meuwissen RA (voorzitter)

Prof. dr. W.H. Gijselaers

Prof. dr. J.G. Kuijl RA (Universiteit Leiden)

Prof. dr. J.J.A. Leenaars RA (Universiteit van Amsterdam) 
IF THE CHOICE DOES NOT MATTER, THEN THERE IS NO NEED FOR AN EXPERT JUDGE'

[Pincus, 1990] 


\section{Voorwoord}

De reden waarom ik aan het schrijven van dit proefschrift ben begonnen was tweeledig. Enerzijds vroeg ik me af of de inspanning van mij en mijn collega docenten Administratieve Organisatie in de praktijk effect sorteerden. Hebben wij aan onze studenten echt normatieve kaders meegegeven die ze ook in de praktijk hanteren? Anderzijds waren daar de maatschappelijke ontwikkelingen omtrent 'Corporate Governance', al dan niet ingegeven door deconfitures van grote ondernemingen, die consequenties hebben voor de accountant. Als docent in dit vakgebied ben je je ervan bewust dat de ontwikkelingen in het bedrijfsleven met grote snelheid voortschrijden. Invloeden van geautomatiseerde informatiesystemen maar ook het steeds minder op papier vastleggen van gegevens maken dat een administratief-organisatorisch proces dat toereikend was tot op de dag van vandaag zeer snel als ontoereikend te boek kan komen te staan. Je gaat ervan uit dat alle accountants deze ontwikkelingen volgen en desgevraagd ook tot gelijkluidende beoordelingen komen. Maar zo vroeg ik me af, is dit nu wel zo, kan ik een administratief-organisatorisch proces aan een willekeurige accountant voorleggen en krijg ik dan in alle gevallen ook een gelijkluidend antwoord. Als dat niet zo is ligt het gevaar op de loer dat een onderneming, als zij behoefte heeft aan een beoordeling van een administratief-organisatorisch proces, rond gaat kijken om een hem zo gunstig mogelijk oordeel te krijgen en dat 'opinion shoppen' is niet bevordelijk voor het imago van het accountantsberoep. Het is dan ook een onderzoek dat naast het leveren van een wetenschappelijke bijdrage ook relevant is voor het maatschappelijk verkeer in het algemeen en de accountantsprofessie in het bijzonder. Zowel het mattschappelijk verkeer als de accountantsprofessie hebben er profijt van als accountants gelijkluidende antwoorden geven op gelijke vragen. Dat wordt in deze studie gezien als professional judgment; het is het judgment van de professie en niet van de individuele accountant.

Het schrijven van een proefschrift is niet iets dat je volledig alleen doet. Vele mensen hebben mij daarbij geholpen en die wil ik graag hiervoor bedanken. Het zou te veel zijn ze allemaal hier individueel met naam en toenaam te noemen, ik ben veel te bang ook maar iemand te vergeten. Ik doe het dan ook maar door ze als groep te bedanken, zoals al de accountants die mij onderzoeksgegevens hebben aangereikt, al de studen- 
ten die mij hebben geholpen om de onderzoeksgegevens te verwerken, al degene die hebben meegelezen en correcties hebben aangedragen, de vele collega's maar vooral mijn eigen familie en niet in het minst mijn kinderen die mijn verhalen hebben moeten aanhoren en te beleefd waren om mij mijn mond te snoeren, mijn beide promotoren en mijn twee paranimfen. Één iemand wil ik hierbij expliciet noemen en bedanken en dat is mijn lieve vrouw Annette. Ik wil haar vooral bedanken voor de ruimte die ze me in al die jaren heeft gegeven om dit onderzoek uit te voeren en dat in de spaarzame vrije tijd die ik had. Ik had het nooit kunnen voltooien zonder haar niet aflatende steun en begrip; Annette van harte bedankt.

Apeldoorn, 18 november 2005 


\section{Inhoudsopgave}

1. Inleiding 11

1.1. Doelstelling van dit onderzoek ................... 12

1.2. Het belang van Administratieve organisatie . . . . . . . . . 15

1.3. Onderzoeksvragen . . . . . . . . . . . . . . . . 26

1.4. Relevantie van dit onderzoek ... . . . . . . . . . . . 31

2. Voorgaand onderzoek 37

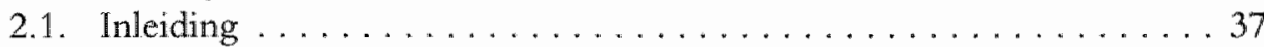

2.2. Het model van libby algemeen . . . . . . . . . . . . . 37

2.3. Het model van libby per variabele . . . . . . . . . . . . . . . . 39

2.4. Het begrip professional judgment $\ldots \ldots \ldots \ldots \ldots \ldots \ldots \ldots \ldots$

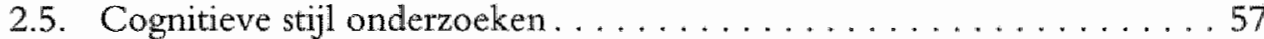

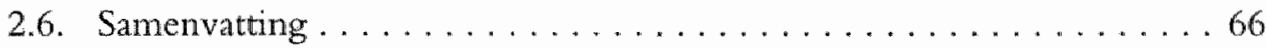

3. Vorming hypotheses en Invulling model 73

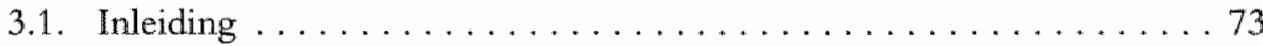

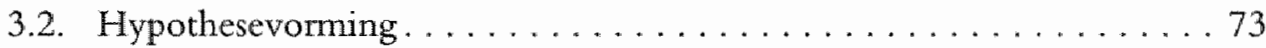

3.3. Invulling van het model van libby per variabele $\ldots \ldots \ldots \ldots \ldots . \ldots 8$

4. De onderzoeksopzet 93

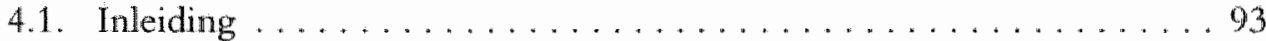

4.2. Gekozen onderzoekstype . . . . . . . . . . . . . . . 94

4.3. Onclerzoeksinstrumenten ... . . . . . . . . . . . . . . . 95

4.4. Respons... . . . . . . . . . . . . . . . . . . . . . . 108

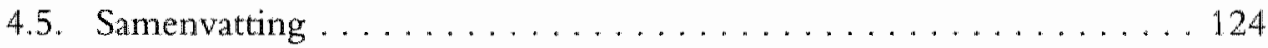

$\begin{array}{lr}\text { 5. } & \text { Resultaten } \\ & 127\end{array}$

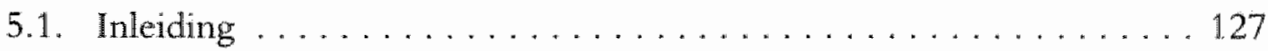

5.2. Consensus tussen oordelen van accountants . . . . . . . . . . . 128

5.3. 'Voorkeur' van de accountant . . . . . . . . . . . . . . 162

5.4. Het psychologische profiel van de accountant. . . . . . . . . . . 167

5.5. Samenvatting ............................ 170 
6. Beantwoording onderzoeksvragen $\quad \mathbf{1 7 5}$

6.1. Hypotheses geplaatst in het model van libby . . . . . . . . . 175

6.2. Consensus tussen de oordelen van accountants . . . . . . . . 178

6.3. 'Voorkeur' van de accountant? . . . . . . . . . . . . . . . . . . . . 182

6.4. Het psychologische profiel van de accountant. . . . . . . . . 185

6.5. Consequenties voor de accountantsprofessie . . . . . . . . . 188

6.6. Samenvatting . . . . . . . . . . . . . . . . . . . . . . . . 190

$\begin{array}{ll}\text { Literatuur } & 193\end{array}$

$\begin{array}{ll}\text { Bijlagen } & 202\end{array}$

$\begin{array}{ll}\text { Index figuren } & 271\end{array}$

Summary 275

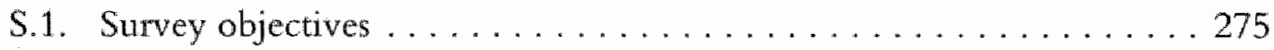

S.2. The need for an internal control structure . . . . . . . . . . 276

S.3. Previous research . . . . . . . . . . . . . . . . . . 277

S.4. Research questions and hypotheses . . . . . . . . . . . . 278

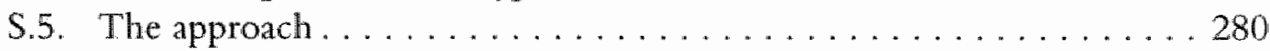

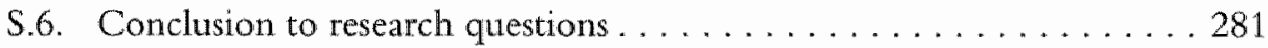

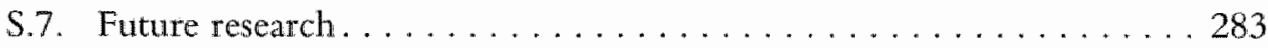

$\begin{array}{ll}\text { Curriculum Vitae } & 285\end{array}$ 


\section{HOOFDSTUK 1}

\section{Inleiding}

Dit proefschrift gaat over het professional.judgment van de accountant bij de beoordeling van administratief-organisatorische processen. In de afgelopen decennia hebben buiten Nederland regelmatig onderzoeken plaatsgevonden naar de professionele oordeelsvorming van accountants ${ }^{1}$. Door de nationaliteit van de accountants die betrokken zijn in dit onderzoek richt dit onderzoek zich op de Nederlandse accountantsprofessie.

Professional judgment kan bekeken worden vanuit de accountantsprofessie en vanuit de individuele accountant; het 'judgment van de professie' of het 'judgment van de professional'. Het judgment van de professie is de representatie van het geheel van oordelen gegeven door het collectief van individuele professionals behorende tot een specifieke professie [Van Eijkelenburg, 2001]. In de onderhavige studie wordt met 'professional judgment' het 'judgment van de accountantsprofessie' bedoeld; indien gedoeld wordt op het judgment van de individuele accountant wordt dit aangegeven met 'judgment van een professional'.

In hoofdstuk 1 worden de doelstelling en relevantie van dit onderzoek besclireven, gevolgd door een meer theoretische beschouwing vanuit een onderzoeksmodel in hoofdstuk 2. Hoofdstuk 3 omvat een beschrijving van de invulling van het onderzoeksmodel alsmede de hypothesevorming, waarna de onderzoeksopzer beschreven wordt in hoofdstuk 4 . In de hoofdstukken 5 en 6 worden respectievelijk de resultaten en de conclusies van het onderzoek behandeld waarbij tevens wordt ingegaan op mogelijk vervolgonderzoek.

In dit eerste hoofdstuk wordt stilgestaan bij de doelstelling van dit onderzock en het belang van het geven van een oordeel over de kwaliteit van administratief-organisatorische processen. Dit belang wordt zowel bezien vanuit de regelgeving van het accountantsberoep als vanuit de individuele accountant. Vervolgens worden de onderzoeksvragen geformuleerd die in het vervolg van dit onderzoek zullen worden beantwoord. Het hoofdstuk wordt afgesloten met een beschouwing over de relevan- 
tie van dit onderzoek voor het matschappeljik verkeer, de accountantsprofessie, de werkzaamheden van de accountant en de opleiding van accountants.

\subsection{Doelstelling van dit onderzoek}

De doelstelling van dit onderzoek is om een bijdrage te leveren aan het internationaal onderzoek naar het professional judgment van de accountant bij de beoordeling van administratief-organisatorische processen. Inzicht in dit professional judgment van de accountant bij de beoordeling van deze processen is noodzakelijk. Dit wordt mede veroorzaakt doordat door het maatschappelijk verkeer aan de accountantsprofessie wordt gevraagd om transparantie in thaar manier van oordeelsvorming en de daarop gebaseerde uitingen.

Mede door recentelijke deconfitures van grote ondernemingen ${ }^{2}$ neemt de roep vanuit het maatschappelijke verkeer toe om meer duidelijkheid in de beheersing van de bedrijfsprocessen van de onderneming [AICPA, 2004; PCAOB, 2004; IFAC, 2003d; Swinkels, 2003; Tabaksblat, 2003; ICAEW, 2003; Sarbanes-Oxley Act ${ }^{3}$, 2002; Mouthaan, 2001, 2000; Erickson, Mayhew en Felix, 2000]. Bij mededelingen van het management over de beheersing van deze bedrijfsprocessen wordt in sommige gevallen een bevestiging van deskundigen gevraagd. De accountant wordt in dit kader, zeker in de Angelsaksische landen, als deskundige bij uitstek gezien. Het nadenken, oordelen en rapporteren over de vraag of het management van een onderneming zijn bedrijfsprocessen beheerst, is onderdeel van de discussie die bekendheid heeft gekregen onder de naam Corporate Governance [PCAOB, 2004, 2003; COSO 2004, 1992; Tabaksblat, 2003; ICAEW, 2003; Winter, Garrido Garcia, Hopt, Rickford, Rossi, Schans Christensen en Smon, 2002; Gregory en Simmelkjaer, 2002; Mouthaan, 2001, 2000; Den Boer en Van Zutphen, 1999; Vaassen en Beek, 1997]. Deze discussie wordt nog eens geintensiveerd naar aanleiding van de zogernamde Azië-crisis en de nieuwe organisatievormen die in de huidige matschappij ontstaan, zoals multinationale conglomeraten en virtuele ondernemingen [Nieuwelaar en Vatassen, 2001].

In de afgelopen decennia is veel onderzoek gedaan naar de wijze waarop accountants hun oordelen vormen ${ }^{4}$. Hierbij is veelvuldig gebruik gemaakt van onderzoeken op het gebied van gedragswetenschappen, voor zover deze betrekking hadden op beslissingstheorieën en de wijze waarop door mensen informatie wordt verwerkt. Op grond van de witkomsten van deze onderzoeken, gericht op het oordeelsvormingproces van de accountant, heeft Libby [1995] een generiek model ontwikkeld. Dit model is gebaseerd op conceptuele relaties die onderzocht zijn in aan kennis gerelateerde studies door Libby en Tan [1994], Frederick [1991], Bonner en Lewis 
[1990] en Frederick en Libby [1986]. Dit model maakt, zoals in figutur 1.1. is weergegeven, de aan kennis gerelateerde variabelen van het door Libby [1995] genoemde 'audit judgment performance' in hun onderlinge verband zichtbaar. In deze studie is 'audit judgment performance" vertaald met de term 'kwaliteit accountantsoordeel'.

Het model is ontwikkeld vanuit een tweetal functies, te weten:

Kwaliteit accountantsoordeel $=f\{$ Aanleg, Kennis $\}$

Kennis $=f$ Aanleg, Ervaring $\}$

Op het model, door Libby aangeduid met de term "The Antecedents and Consequences of Knowledge" [Libby, 1995; Libby en Luft, 1993], wordt in hoofdstuk 2 nader ingegaan.

Onwille van de beheersbarheid van het model is door Libby [1995] een tweetal aannames gedaan. Enerzijds is aangenomen dat de motivatie voor alle accountants een constante is en anderzijds dat de omgevingsfactoren, welke niet door de accountant beinvloedbaar zijn, alleen in beschouwing worden genomen voor zover het object van onderzoek dit vereist.

Het model kent een viertal variabelen. Twee zijn te zien als input variabelen 'Ervaring' en 'Aanleg' en één als output variabele 'Kwaliteit accountantsoordeel'. De vierde variabele 'Kennis' wordt gezien als een 'intermediate'-output variabele [Libby, 1995]. De input variabele 'Ervaring' wordt ook wel onderverdeeld in 'Instructie' en 'Ervaring'. Zowel de input variabele 'Aanleg" als de 'intermediate'output variabele 'Kennis' zijn niet rechtstreeks waar te nemen maar moeten worden afgeleid of worden waargenomen met behulp van een proxy. Bij de daarbij te hanteren testen wordt in de volgende hoofdstukken stilgestaan.

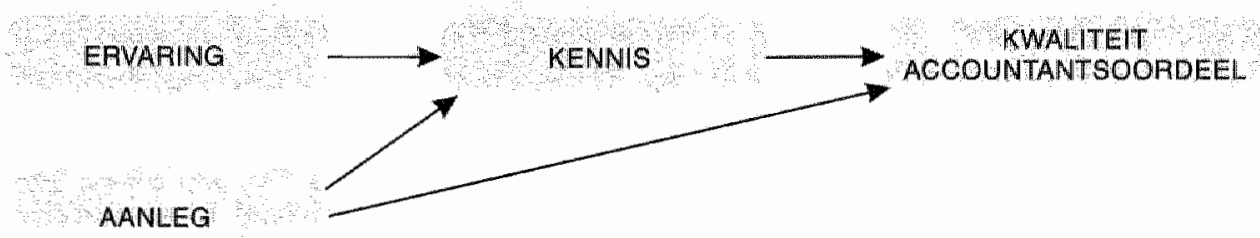

Figune 1. 1: The Antecedents and Consequences of Knowledge bron: Libby 1995)

Libby [1995] stelt voorts dat het model sterk taakgericht is. Voor iedere specifieke taak dient het model te worden ingevuld met alleen die variabelen, die relevant zijn voor die taak. In hoofdstuk 2 wordt in meer algemene zin ingegaan op de verschil- 
lende variabelen uit het model van Libby [1995]. In dit onderzoek worden de wariabelen ingevuld met de elementen die betrekking hebben op de specifieke taak van de accountant "het beoordelen van een specifiek administratief-organisatorisch proces". Dit proces wordt weergegeven als een "AO-proces". Het model, op de invulling waarvan in hoofdstuk 3 nader wordt ingegaan, ziet er dan als volgt uit.

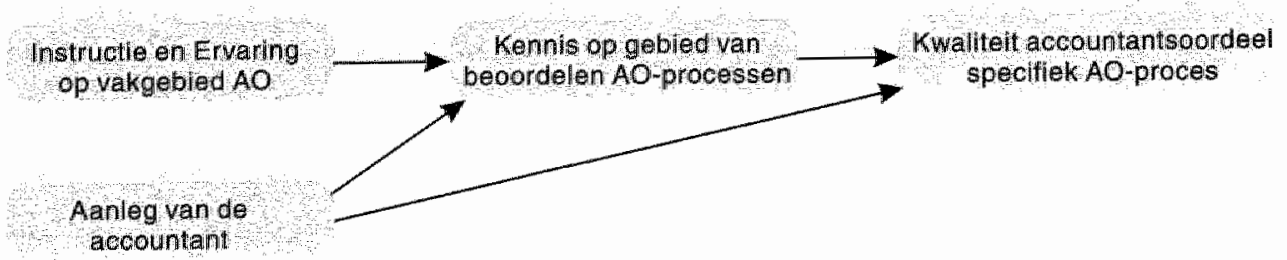

Figutir 1.2: Op Administratiaf-Organisatorsch proces togepast model van Libby (naar: Libby 19g5)

Zoals hierboven gesteld, is de doelstelling van dit onderzoek "het leveren van een bijdrage an het onderzoek naar het professional judgment van de accountant bij de beoordeling van administratief-organisatorische processen'. Aan deze doelstelling wordt in dit onderzoek invulling gegeven door na te gaan in hoeverre accountants gelijkluidende oordelen geven bij de beoordeling van een specifiek administratieforganisatorisch-proces. In het onderhavige onderzoek is gekozen voor het gehele administratief organisatorische proces dat zich voltrekt op de afdeling Personeelszaken war onder begrepen het aannemen wan personeel, de prestatie beoordeling, het ontslaan van personeel alsmede de gehele financiele afhandeling, de interne controles en de administratieve vastlegging, hierna kortheidshalve te noemen het Personeelszakenproces ${ }^{5}$. De bij het onderzoek betrokken accountants hebben oordelen gegeven over de kwaliteit van een aantal verschillende varianten van het Personeelszakenproces. Deze varianten van het Personeelszakenproces zijn aan accountants gepresenteerd in de vorm van casusstellingen ${ }^{6}$. Bij het ontwerpen van de casusstelling is een aantal groepen beheersingsmaatregelen onderscheiden: de onafhankelijke variabelen. Met deze groepen beheersingsmaatregelen is gevarieerd in het an de accountant gepresenteerde casusmateriaal. Aan de accountants is gevraagd een oordeel te geven over de kwaliteit van het Personeelszakenproces zoals beschreven in de gepresenteerde casusstelling. Dit oordeel kon worden uitgedrukt op een zevenpuntsschaal, zonder dat de accountant verplicht werd dit oordeel te motiveren. Tevens is in het onderzoek nagegaan in hoeverre het hebben van een voorkeur voor een specifieke groep beheersingsmaatregelen invloed heeft op het door die accountant gegeven oordeell.

In de volgende paragraaf wordt stilgestaan bij het belang van de kwaliteit van administratief-organisatorische processen voor de oordeelsvorming van de accountant 
Hierbij wordt dit belang eerst bezien vanuit de voor het accountantsberoep geldende regelgeving. Vervolgens wordt dit belang bezien vanuit het kennisbeeld van de individuele accountant. De paragraaf wordt afgesloten met een conclusie over de aanwezigheid van een 'common body of knowledge' ten aanzien van het vakgebied Administratieve Organisatie binnen de accountantsprofessie.

\subsection{Het belang van administratieve organisatie}

\subsubsection{Administratieve organisatie en de voor het accountantsberoep geldende regelgeving}

In de tweede helft van de $20^{\text {ste }}$ eeuw is de reglementering van het accountantsberoep nationaal en international tot stand gekomen. De regelgeving voor het accountantsberoep omvat zeer veel verschillende aspecten. Lang niet al deze aspecten zijn van belang voor het onderhavige onderzoek. In de regelgeving wordt expliciet aandacht besteed aan het beoordelen van administratief-organisatorische processen. Tevens wordt het belang daarvan onderstreept. In deze paragraaf wordt een beschouwing gegeven over het belang dat aan het beoordelen van administratieve processen wordt gegeven, bezien vanuit de voor het accountantsberoep geldende regelgeving.

Bij het uitvoeren van zijn controlewerkzaamheden heeft de accountant zich gecommitteerd aan het volgen van controlestandaarden welke standaarden mede door de hiervoor beschreven ontwikkelingen continu worden angescherpt [IFAC, 2003d; Leonard, Lincsell en Turley, 2003]. Teruggaand in de historie werd in 1948 een tiental controlestandaarden onder de naam 'generally accepted auditing standards' (US-GAAS) door het American Institute of Certified Public Accountants (AICPA) vastgesteld. Vanaf 1977 zijn "International Standards on Auditing and Related Services' (ISA's) geformuleerd en uitgevaardigd door de International Auditing Practices Committee (IAPC). De IAPC was cen vaste commissie van de International Federation of Accountants (IFAC) en is in 2002 vervangen door de International Auditing and Assurance Standards Board (IAASB). Met het hechten van haar goedkeuring aan het voorwoord bij de 'International Standards on Auditing and Related Services' (ISA's) in 1994 stelde de Council van de IFAC de reikwijdte en het gezag van deze standaarden vast [IFAC, 1999]. Door het Koninklijk Nederlands Instituut van Registeraccountants (NIVRA) werden deze ISA's vanaf 1996 van kracht verklaard voor de in Nederland praktiserende registeraccountants, onder de benaming 'Richtlijnen voor de Accountantscontrole' (RAC's) [NIVRA, 2003]. Deze RAC's hebben de status van 'gezaghebbende uitspraken' van het bestuur van het NIVRA hetgeen minder is dan kracht van wet [Majoor, 1997]. 
Om tot een oordeel te kunnen komen zal de accountant controlewerkzaamheden uitwoeren. Dit gehele proces is te karakteriseren als een doorlopend proces van beslissen [Knechel, 2001; Hayes, Schilder, Dassen en Wallage, 19997]. Vanaf het begin van zijn werkzaamheden zal de accountant op basis van zijn bevindingen een beslissing moeten nemen omtrent de vervolgwerkzamheden teneinde tot een deugdelijke grondslag voor zijn oordeel te kunnen komen. Bij dit oordeel zijn verschillende gradaties van zekerheid mogelijk. Bij een controleopdracht verschaft de accountant een (relatief) hoge, maar niet absolute, mate van zekerheid dat de gecontroleerde informatie geen onjuistheden van materieel belang bevat ${ }^{9}$. Bij de afwegingen die de accountant moet maken om tot de gewenste mate van zekerheid te kunnen komen kan de accountant gebruik maken van zogenaamde 'audit risk"-modellen. Deze modellen zijn zowel in de US-GAAS ${ }^{10}$ als in de ISA's ${ }^{11}$ en RAC's ${ }^{12}$ opgenomen en lijken in de beschrijwingen sterk op elkaar. Deze 'audit risk'-modellen beschrijven het risico dat de accountant loopt bij de uitvoering van zijn werkzaamheden in het kader van de controle van de jaarrekening. Dat ook in Nederland hieromtrent een langjarige discussie platsvindt blijkt onder meer uit een tweetal gezaghebbende publicaties te weten het NIVRA-geschrift nummer 49, "Accountantsontrolerisico", [NIVRA, 1989] en de publicatie "Risico's en oordeelsvorming in de accountantspraktijk" van het Limperg Instituut [Limperg Instituut, 1990].

In de 'audit risk'-modellen wordt een viertal risico's met elkaar in relatie gebracht. Het accountantscontrolerisico ${ }^{13}$ wordt hierbij gezien als een resultante van een drietal andere risico's, te weten het inherent risico ${ }^{14}$, het interne beheersingsrisico ${ }^{15}$ en het ontdekkingsrisico ${ }^{16}$. Van deze laatst drie risico's is alleen het ontdekkingsriciso rechtstreeks door de accountant te beinvloeden. Het niet ontdekken van een onjuistheid van materieel belang kan het gevolg zijn van het in onvoldoende mate verrichten van werkzaamheden dan wel het inzetten van een controleteam met onvoldoende kennis en ervaring. Het inherente risico en het interne beheersingsrisico worden bepald door de organisatorische entiteit dat object van onderzoek is van de accountant bij het uitvoeren van zijn controleopdracht. De onderlinge relatie is weergegeven in onderstaande formule welke al jaren lang internationaal gehanteerd wordt:

Accountantscontrolerisico $=$ Inherent risico $\times$ Interne beheersingsrisico $\times$ Ontdekkingsrisico.

Op grond van de discussies die in de afgelopen decennia over deze risicobenadering zijn gevoerd en omdat de verschillende risico's niet geheel onafhankelijk van elkar zijn, constateren Hayes, Schilder, Dassen en Wallage [1999] ${ }^{17}$, Wilschut [1997] en Schilder [1991] dat het hiervoor beschreven model van risicobenadering geen rekenmodel is. Het "audit risk"-model moet worden beschouwd als een denkmodel 
dat de accountant ondersteunt bij het programmeren van zijn accountantsarbeid. Dit denkmodel kan beter worden uitgedrukt in een functie, te weten:

Accountantscontrolerisico $=f$ Inherent risico, Interne beheersingsrisico, Ontdekkingsrisico $\}$

Uitgaande van een voor de accountant acceptabel niveau van Accountantscontrolerisico en het door de accountant vastgestelde niveau van het Inherent risico en Interne beheersingsrisico kan de accountant vaststellen welk niveau van Ontdekkingsrisico voor hem acceptabel is. Direct daaraan gekoppeld is dan de hoeveelheid gegevensgerichte werkzaamheden die moet worden uitgevoerd ${ }^{18}$.

Het is derhalve van groot belang dat een zo juist mogelijke inschatting van het Inherent risico en Interne beheersingsrisico plaatswindt. Dat wordt ook onderkend in de RAC 400 [NIVRA, 2003]. In artikel 2 is alls gronds]ag ${ }^{19}$ bepaald: 'De accountant diest voldoende inzicht in de administratieve organisatie en inteme controle te verkrijgen on de controle te kunnen voorbereiden en een effectieve controleanpak te kunnen opzetten. De accountant dient op grond van vakkundige oordeelsvorming het nivenu van het accountantscontrolevisico in te schatten en zijn controlewerkzaamheden zodanig op te zetten en in te richten dat een aamvaardbaar laag niveau van het accountantscontrolerisico is gewaarborgd.

Om voldoende inzicht in de Administratieve Organisatie, de beheersingsomgeving alsmede de getroffen interne beheersingsmaatregelen te verkrijgen zijn in de RAC $400^{20}$ essentiële werkzaamheden beschreven. Op grond hiervan kan de accountant een initiële inschatting van het Interne beheersingsrisico maken. Tevens wordt in de RAC $400^{21}$ aangegeven dat de initiële inschatting van het Interne beheersingsrisico hoog dient te zijn, tenzij de accountant:

- in staat is maatregelen van interne beheersing te identificeren die relevant zijn voor de bewering en die erop gericht zijn onjuistheden van materieel belang te voorkomen of te doen ontdekken en te herstellen; en

- voomemens is systeemgerichte werkzaamheden uit te voeren om de aanvaardbaarheid van zijn inschatting te ondersteunen.

Dat het belang van de kwaliteit van de Administratieve Organisatie en het stelsel van interne beheersingsmaatregelen voor de efficiëntie van de uitvoering van de controle al lang wordt onderkend, hebben Mock en Turner [1999] in hun anthologie beschreven. Zij gaan daarbij terug naar het begin van de twintigste eeuw alwaar in 1917 Robert H. Montgomery schreef dat if the auditor has satisfied himself that the system of internal check is adequate, he will not attempt to duplicate work which has been properly performed by someane else,22. 
De door de accountants gehanteerde risicobenadering is nog steeds valide ofschoon steeds weer onderhevig aan onderzoek [Blokdijk, 2004, 2002, Klinsmit, Sodekamp en Wallage, 2003; Bedard en Graham, 2002; Koning, 2002; Wu, Roebuck en Fargher, 2002; Eilifsen, Knechel en Wallage, 20011. Dat de risicobenadering nog steeds valide is blijkt uit de resultaten van een door de Public Oversight Board uitgevoerde studie naar de huidige controlemethoden van onathankelijke accountants. Dit onderzoek is uitgevoerd in opdracht van de Securities and Exchange Commission (SEC). De uitvoering van deze studie was neergelegd bij een daarvoor speciaal samengesteld 'Panel on audit effectiveness' 23 dat ondersteund werd door een professionele staf [Public Oversight Board, 2000]. In deze studie is witgebreid aandacht besteed aan het hiervoor beschreven 'audit risk'-model ${ }^{24}$. Naar aanleiding hiervan is het Panel tot de volgende conclusie gekomen: 'The model calls for auditors to have an understanding of the entity's business and indwstry, the system employed to process transactions, the quality of personnel involved in accounting functions, and the entity's policies and procedures related to the preparation of financial statements. The model requires anditors to gain understanding of an entity's internal controls..... ' Het Panel stelt in haar rapport tevens dat of schoon het 'audit risk'-model een model is dat uitnodigt tot een mathematische voortgang van de controle, dit model in werkelijkheid gebaseerd is op een grote mate van judgment. "The objective in an andit is to limit audit risk to a low level, as judged by the anditor'. ${ }^{25}$

Het grote belang dat gehecht wordt aan het systeem van Administratieve Organisatie blijkt ook uit de kennisvereisten die aan de accountant worden gesteld en zijn omschreven door de Education Committe ${ }^{26}$ van het IFAC. In het curriculum voor de accountantsopleiding neemt kennis over organisaties, het voeren van een onderneming in het algemeen en de beoordeling van bedrijfsprocessen in het bijzonder een centrale plaats in ${ }^{27}$.

In de in december 2003 verschenen International Framework for Assurance Engagements [IFAC, 2003b] zijn de elementen opgenomen van assurance-opdrachten die gericht zijn op het verschaffen van een hoge of een beperkte mate van zekerheid ${ }^{28}$. As éen van de vijf essentiële elementen ${ }^{29}$ van een assurance-opdracht wordt genoemd het aanwezig zijn van adequate criteria. Criteria zijn de nomen die gebruikt worden om het object van onderzoek bij een assurance-opdracht te evalueren of te meten. Zonder dit referentiekader zou bij een conclusie c.q. oordeel ruimte zijn voor individuele interpretaties. Voor assurance-opdrachten dienen de criteria adequaat te zijn om, binnen het kader van een professionele oordeelsvorming, een redelijk consistente evaluatie of meting van het object van onderzoek mogelijk te maken. Adequate criteria zijn context-afhankelijk $\mathrm{k}^{30}$ 
Als één van de mogelijke typen assurance-opdrachten ${ }^{31}$ noemt het Framework het geven van assurance bij 'systemen en processen'. Hierbij wordt het geven van assurance bij onderzoeken naar de kwaliteit van interne beheersingsmaatregelen als voorbeeld genoemd. Ten behoeve van zo'n onderzoek naar de kwaliteit van interne beheersingsmaatregelen dienen de criteria te bestaan uit een voor algemeen gebruik vastgesteld raamwerk van interne beheersingsmaatregelen of uit ad-hoc voor dat specifieke doel geformulleerde en toegelichte criteria ${ }^{32}$.

Niet alleen in de regelgeving van het accountantsberoep komt het grote belang van de beoordeling van administratieve processen tot uitdrukking. Ook de sinds 25 juli 2002 van kracht zijnde 'Sarbanes-Oxley Act' [Sarbanes-Oxley Act, 2002] in de Verenigde Staten van Amerika onderschrijft het belang van een adequate Administratieve Organisatie en interne beheersing. Indien een onderneming valt onder het toezicht van de Securities and Exchange Commission (SEC), wordt het management krachtens deze wet verplicht te rapporteren over de effectiviteit van de getroffen interne beheersingsmaatregelen. Voorts wordt de accountant die de jaarrekening controleert verplicht bij deze rapportage een verklaring te geven. In section 404 'Management assessment of internal control' wordt daarover gesteld: 'The Commission shall prescribe rules requining each annual report required by section $13(\mathrm{a})$ or $15(\mathrm{~d})$ of the Securtites Exchange Act of 1934 to contain an internal control report, which shall:

1. state the responsibility of management for establishing and maintaining an adequate internal control structure and procedures for financial reporting; and

2. contain an assessment, as of the end of the most recent fiscal year of the issuer, of the effectiveness of the internal control structure and procedures of the issuer for financial reporting.

With respect to the internal control assessment required, each registered public acconting firnt that prepares or issues the audit report for the isster shall attest to, and report on, the assessment made by the mantagement of the issuer. An attestation made under this subsection shall be wade in accordance with standards for attestation engagements issued or adopted by the Board. Any such attestation shall wot be the subject of a separate engagentent." [Sarbanes-Oxtey Act, 2002].

In deze paragraaf is een beschouwing gegeven over het belang dat gehecht moet worden aan het vormen van een oordeel over de kwaliteit van administratief-organisatorische processen, tegen de achtergrond van standaarden en regelgeving. Gebleken is dat aan de beoordeling van de Administratieve Organisatie en de daarin begrepen maatregelen van interne beheersing van verschillende zijden groot belang wordt gehecht. Aan deze beoordeling wordt tevens een centrale plaats toegekend bij de controle van de jaarrekening en andere assurance-opdrachten. 
In de volgende paragraaf wordt stilgestaan bij de wijze waarop de individuele accountant in Nederland met dit vakgebied in anraking komt.

\subsubsection{Administratieve organisatie en het kennisbeeld van de individuele accountant}

Het vak Administratieve Organisatie stat zowel centraal binmen de accountantsopleiding als bij de wijze warop de controle door accountantskantoren wordt uitgevoerd. Dit blijkt vooral doordat het vak Administratieve Organisatie:

a. éen van de kernwakken in het curriculum van de accountantsopleiding is;

b. centraal stalat in de controlemethodologieën van de accountantskantoren;

c. tijdens de controlewerkzaamheden door beroepsgenoten met meerdere jaren ervaring vanuit de praktijk nader wordt ingevuld, de zogenaamde "training on the job'.

De theoretische basis is voor alle individuele accountants in Nederland gelijk. De praktische invulling wordt vormgegeven door de controlemethodologieën van de accountantsmaatschappen en de 'training on the job'. Gelet op het belang dat vanuit de regelgeving van de beroepsgroep, zowel nationaal als internationaal, wordt gehecht aan de beoordeling van de Administratieve Organisatie, zullen de verschillende controlemethodologieẻn niet veel van elkaar afwijken. Van de bijbehorende "training on the job" mag aangenomen worden dat deze ten aanzien van de beoordeling van de Administratieve Organisatie, gellijk gestemd zal zijn.

In het vervolg van deze paragraaf wordt op de hiervoor gegeven punten nader ingegaan. Daarbij wordt met name aandacht besteed aan de bijdrage die elk van de hiervoor gegeven punten levert aan het "common body of knowledge' aspect van het vak Administratieve Organisatie.

\section{Ad a. Het kermak Administratieve Organisatic}

Mede door de in Nederland heersende tendens zoveel mogelijk de internationale IFAC standaarden en richtlijnen te wolgen, behoort het vak Administratieve Organisatie $^{33}$ tot de kernvakken in de opleiding tot accountant [Vaassen en Beek, 1997]. In de International Education Standard 2 (IES 2) 'Content of professional accounting education programs' [IFAC, 2003a] en de daaraan voorafgaande accreditatierichtlijn 'Recognition of Professional Accountancy Qualifications, Statement of Policy of Council' [IFAC, 1999], wordt gesteld dat personen die professionele erkenning behoeven, onder andere ten minste kennis moeten hebben van "internal control systems 34 . 
Het definiëren en beschrijven van her vakgebied Administratieve Organisatie alsmede de discussie over het belang van dit vakgebied kent in Nederland een jarenlange geschiedenis.

Administratieve Organisatie kan omschreven worden als:

- het gehele complex van organisatorische maatregelen en maatregelen van interne beheersing dat direct of indirect betrekking heeft op de goede werking van de bestuurlijke informatieverzorging.

Het daarmee zo sterk verweven begrip 'administreren" wordt omschreven als:

- het systematisch verzamelen, vastleggen, en verstrekken van economisch-financiële informatie.

Dit administreren vindt plaats ten behoeve van:

- de besluitvorming;

- het (doen) functioneren en besturen van een organisatie;

- de verantwoording die daarover moet worden afgelegd [Starreveld, 1962].

Onder interne beheersing wordt verstaan:

- het geheel van maatregelen van beheersing die door of namens het management van een organisatie wordt uitgeoefend op de bestuurlijke en technische activiteiten in die organisatie ten behoeve van dat management [Jans, 1994].

Het doel van de interne beheersing kan omschreven worden als:

- het tijdig opsporen en corrigeren van onvolkomenheden in de uitoefening van bedrijfsactiviteiten, alsmede

- het scheppen van de mogelijkheid om zonodig nieuwe maatregelen te treffen teneinde te voorkomen dat de gesignaleerde onvolkomenheden in de toekomst weer optreden [Starreveld, De Mare en Joëls, 1997].

Dit doel sluit aan bij de Richtlijn 400 [NIVRA, 2003]. Deze maatregelen van interne beheersing vormen op zichzelf weer een onderdeel van de Administratieve Organisatie en dragen bij tot het verkrijgen van betrouwbare economisch-financiële informatie.

Zoals uit vorenstaande blijkt richt de Administratieve Organisatie zich op de goede werking van de bestuurlijke informatieverzorging. In ruime zin wordt "bestuurlijke informatieverzorging" geinterpreteerd als het verzorgen van informatie ten behoeve van het besturen van een organisatie [Swigchem, 1987]. Daarnaast wordt 'bestuurlijke informatieverzorging' geïnterpreteerd als het verstrekken van effectieve en efficiënte, alsmede relevante en betrouwbare, informatie aan alle belanghebbenden van een organisatie [Beek en Vaassen, 1999]. Informatie wordt daarbij 
omschreven als gegevens die bijdragen aan het kennisbeeld van de mens c.q. gegevens die betekenis hebben. Wat voor de éen informatie is, hoeft dat voor een ander niet te zijn. Ofschoon niet alle belanghebbenden behoefte hebben aan dezelfde informatie dient alle informatie te voldoen aan de eisen van relevantie en betrouwbaarheid:

Het management van de organisatie is verantwoordelijk voor het vormgeven en in stand houden van het geheel van administratief-organisatorische processen, alsmede de daarin opgenomen maatregelen van interne beheersing. Deze maatregelen van interne beheersing worden in dit onderzoek de beheersingsmaatregelen genoemd. De informatiebehoefte van de belanghebbenden is van grote invloed op de inrichting van de Administratieve Organisatie. Aangezien de leiding van de organisatie de meest directe belanghebbende is, zal de Administratieve Organisatie sterk beinwloed zijn door de leiding wan de organisatie. Zodoende is in belangrijke mate sprake van situationeel bepaalde administratief-organisatorische processen met de daarin opgenomen situationeel bepalde beheersingsmaatregelen.

De accountant dient desondanks in staat te zijn tot een oordeel over de kwaliteit c.q. de effectiviteit van de Administratieve Organisatie. Overeenkomstig het hiervoor beschreven internationaal gehanteerde 'audit risk'-model zal dit oordeel van de accountant richtinggevend zijn voor de verdere controle-inspanningen.

De centrale plaats die het vak Administratieve Organisatie inneemt in het curriculum van de accountantsopleiding wordt dethalve niet alleen veroorzakt door de International Education Standard 2 (IES 2) "Content of professional accounting education programs' [IFAC, 2003a]. Ook de reeds jarenlange discussie over het belang van het vakgebied, alsmede de international gehanteerce 'audit risk' modellen geven hier aanleiding toe. Daarnaast toont het jarenlang bestaand landelijk schriftelijk en mondeling examen Administratieve Organisatie het gewicht aan dat aan dit kernvak in Nederland wordt gehecht. Door dit landelijk schriftelijk examen zien de opleiders en opleidende instanties zich genoodzaakt de inhoud van het vakgebied Administratieve Organisatie te laten ansluiten bij het gedachtegoed van het Examenbureau. Eventueel afwijkende visies worden zodoende zoveel mogelijk genivelleerd. Met ingang van 2004 is dit landelijk examen afgeschaft. Iedere accountant ingeschreven in het register van het Koninklijk NIVRA voor 2004 is verplicht geweest dit landelijk examen af te leggen en heeft derhalve kennis moeten nemen van het kerrvak Administratieve Organisatie [Vaatstra, 1996].

\section{Ad b. De aanpassingen van de controlemethodologieen}

Vanuit de accountantskantoren wordt ingespeeld op ontwikkelingen binnen het vakgebied Administratieve Organisatie. Gelet op het belang van de beoordeling van de Administratieve Organisatie voor de controle van de jaarrekening worden de 
controlemethodologieën zoveel mogelijk op deze ontwikkelingen afgestemd [Lemon, Tatum en Turley, 2000]. De ontwikkelingen binnen het vakgebied Administratieve Organisatie worden ingegeven door het internationale maatschappelijk verkeer dat veel aandacht toont voor de beheersing van de bedrijfsprocessen binnen ondernemingen. Dit geheel wordt begrepen onder de term 'Corporate Governance'. Zo verscheen in de Verenigde Staten in september 1992 de rapportage van de zogenaamde Committee of Sponsoring Organizations of the Treadway Commission onder de titel "Internal Control - Integrated Framework" [COSO, 1992]. Rond dezelfde tijd, december 1992, verscheen in het Verenigd Koninkrijk een rapport onder de titel 'The Financial Aspects of Corporate Governance', het zogenaamde Cadbury-rapport. In mei 1994 bracht de Criteria of Control Committee in Canada haar eerste rapport uit, het zogenaamde COCO-rapport [Den Boer en Van Zutphen, 1999]. In september 2004 is het vervolg op het COSO-rapport uit 1992 verschenen onder de titel 'Enterprise risk Management - Integrated Framework' waarbij het internal control framework verder wordt uitgebreid naar de risico's die door een onderneming worden gelopen [COSO, 2004].

In oktober 1996 publiceerde in Nederland de Commissie Corporate Governance [1996] haar voorlopige rapport onder de titel 'Een aanzet tot verandering en een uitnodiging tot discussie', ook wel genoemd het rapport-Peters naar de voorzitter van de commissie. Deze rapportage werd in juni 1997 gevolgd door het definitieve rapport 'Aanbevelingen inzake Corporate Governance in Nederland' door dezelfde commissie [Commissie Corporate Governance, 1997, 1996] en in 2003 door de commissie Corporate Governance [Tabaksblat, 2003]. Mouthaan [2001, 2000] concludeert dat de commissie, zonder dit expliciet te stellen, eigenlijk vraagt om een internal control statement waarin de bestuurders verantwoording afleggen over de opzet en werking van het internal control system. Dit is weer in lijn met de ontwikkeling in het Verenigd Koninkrijk als gevolg van het Cadbury rapport [Turnbull, 1999]. Ten behoeve van de Europese commissie zijn de ontwikkelingen op het gebied van corporate governance samengebracht in een "Comparative study of corporate governance codes relevant to the European Union and its member states' [Gregory en Simmelkjaer, 2002].

Door toepassing van nieuwe geautomatiseerde informatiesystemen verschuiven de beheersingsmaatregelen binnen organisaties van financiecl naar niet-financieel. Ook de richting van de beheersingsmaatregelen is door de ontwikkeling en implementatie van geautomatiseerde informatiesystemen veranderd. Hierbij heeft een verschuiving plaatsgevonden van de beheersing van afdelingsprocessen naar de beheersing van bedrijfsprocessen. Risicobeheersing wordt hierbij door het management van organisaties gezien als een essentieel onderdeel van die beheersingsstructuur. Een goede beheersing van de bedrijfsprocessen betekent een goede beheersing van de 
bedrijfrisico's. Een zodanige beheersing zal dan automatisch leiden tot een kwalitatieve verbetering van de informatie, al dan niet van financiële aard, die door die bedrijfsprocessen wordt gegenereerd. Hierdoor neemt ook de kwaliteit van de financièle verantwoordingen toe. De jaarrekening is één van de financiële verantwoordingen wan een onderneming en is tevens het object van controle voor de accountant. Verwacht mag worden dat deze beheersing van bedrijfsprocessen door het management deel uit makt van de controlemethodologieën van de accountantskantoren [Van Leeuwen en Wallage, 2002; Mouthaan, 2001, 2000].

In een achttall bijdragen van auteurs werkzaam bij vooraanstaande accountantsorganisaties $^{35}$, bijeengebracht door de redactie van het Maandblad voor Accountancy en Bedrijfseconomie $(\mathrm{MAB})^{36}$, is een visie gegeven op de huidige en toekomstige positie van de accountant [Gortemaker e.a., 1998]. Deze visie heeft een nieuwe impuls gegeven aan de verdere verdieping van de kennis van de accountant aangaande bedrijfs-en administratief-organisatorische processen en het geven van een oordeel over de kwaliteit daarvan [Eimers, Biggs en Mock, 1997]. De controlemethodologieën worden daarbij aangepast aan de hiervoor genoemde verschuiving in de richting van de beheersing; van afdelingsprocessen naar bedrijfsprocessen. Aangezien accountantskantoren al jarenlang de evaluatie van de getroffen beheersingsmaatregelen zien als een sturend onderdeel van hun controlemethodologie, zal een verschuiving een verandering in de controlemethodologie initiëren [Meservy, Bailey en Johnson, 1986; Brown, 1962]. Uit onderzoek blijkt ook dat de vooraanstaande accountantsorganisaties hopen dat door nieuwe en nog in ontwikkeling zijnde methoden de consensus in de oordelen van de accountants zal toenemen bij de beoordeling van processen en beheersingsmaatregelen [Meservy, Bailey en Johnson, 1986; Libby, Artman en Willingham, 1985].

In de beschrijwing van de controle van organisaties door een van de grote internationale accountantskantoren benadrukken Bell, Mars, Solomon en Thomas [1997] deze ontwikkeling als gevolg van de verschuiving in de richting van de beheersing. Zij stellen dat: "Today's auditor should place more weight on knowledge about the dient's business and industry, and its interactions with its environment, when foming an opinton about the validity of finamcial-statement assertions'. En concluderen dat: "The risk-based strategicsystews approach reflects the systems-thinking view that to audit assertions effectively, the anditor mwst comprehend the client's whole business environment and interpret the role of significant. iransactions from this business knowledge frame - the broader context infuses meaning into the parts'. Het 'Panel on audit effectiveness' [Public Oversight Board, 2000] heeft vastgesteld dat accountants zich bij de controle van de jaarrekening daadwerkelijk richten op het beoordelen van bedrijfs-en administratief-organisatorische processen. Zij komen evenwel met een aantal aanbevelingen die deze anpak verder kan versterken. Daarbij onderscheiden zij binnen de 'internal control' vijf gebieden die volledig 
aansluiten op de definitie die is gegeven in het COSO-model [Den Boer en Van Zutphen, 1999; COSO, 1992] $]^{37}$.

Door vorenstaande ontwikkelingen, nog eens versterkt door de ontwrikkelingen in de Verenigde Staten met de aanvaarding van de Sarbanes-Oxley wet [SarbanesOxley Act, 2002], wordt het belang van de Administratieve Organisatie in de controlemethodologieën onderkend ${ }^{38}$.

\section{Adc. 'Training on the Job'}

Binnen de openbare accountantskantoren wordt de individuele accountant in deze controllemethodologieën geschoold met behulp van onder meer een 'training on the job'. Op basis van Europese regelgeving, in het kader van harmonisatie van de opleiding tot accountant binnen de Europese Gemeenschap, dient een accountant, om in aanmerking te komen voor inschrijving in het accountantsregister, een praktijkstage te doorlopen van drie jaar. In deze drie jaar dient de kandidaat verschillende werkzaamheden in een controle te hebben uitgevoerd en hierover te hebben gerapporteerd. In de praktijkstage wordt specifiek ingegaan op cliëntsituaties. De begeleiding van de praktijkstage wordt gegeven door beroepsgenoten met meerdere jaren ervaring met als doelstelling de kennis en ervaring van die beroepsgenoten zoveel mogelijk door te geven [Eimers, Biggs en Mock, 1997]. Het Stagebestuur van het Koninklijk NIVRA houdt toezicht op de uitvoering van de praktijkstages en de rapportages op dat gebied. Doordat in de controlemethodologieën de beoordeling van de Administratieve Organisatie als sturend voor de uitvoering van de controle wordt gezien, zal ook in de 'training on the job' deze beoordeling een centrale plaats kennen.

\subsubsection{Administratieve organisatie, een conclusie}

Het vakgebied van de Administratieve Organisatie kan gerekend worden totéén van de componenten van de 'common body of knowledge' van de accountantsprofessie. Een grote en voor alle accountants vergelijkbare bijdrage aan de variabele 'Kennis' op het gebied van beoordelen van administratief-organisatorische processen, zoals weergegeven in het op administratief-organisatorische processen toegespitste model van Libby [1995], wordt geleverd door:

- de plaats die het vakgebied Administratieve Organisatie inneemt in de opleiding tot accountant;

- de voorname plats die de Administratieve Organisatie inneemt in de controlemethodologieën van de openbare accountantskantoren;

- de door de accountantskantoren gegeven "training on the job"; en

- de ontwikkelingen op het gebied van corporate governance.

Op basis van de hiervoor gegeven beschouwingen wordt in de volgende paragraf 
een drietal onderzoeksvragen ontwikkeld. Deze onderzoeksvragen zullen in het vervolg van deze studie worden beantwoord.

\subsection{Onderzoeksvragen}

Zoals uit paragraaf 1.2.1. blijkt neemt de belangstelling van het maatschappelijk verkeer voor de Administratieve Organisatie toe. Deze belangstelling richt zich in het bijzonder op de transparantie ten anzien van de verschillende verklaringen die de accountant afgeeft. De discussie in het kader van corporate governance gaat in de richting van het afgeven van een verklaring door het management over de beheersing van de organisatie. Deze managementverklaring moet door de accountant worden bevestigd [Sarbanes-Oxley Act, 2002]. Daarnaast geeft de accountant een verklaring af bij de financiële verantwoording van een organisatie. De controlemethodologieën die door de accountants worden gehanteerd zijn in de afgelopen jaren steeds meer gericht op het steunen op de Administratieve Organisatie vain een onderneming [Gortemaker, Bindenga, Ten Wolde, Van Kollenburg, Wieleman, Krom, Dassen, Coster en Van Sluis, 1998]. De accountant wordt zodoende langs twee wegen geconfronteerd met het doen van een uitspraak over de kwaliteit van de Administratieve Organisatie, te weten bij:

- de accountantsverklaring inzake de beheersing van de organisatie in het kader van de corporate governance-discussie.

Het beoordelen door de accountant van de beheersing door het management van de bedrijfsprocessen dient objectief plaats te vinden. Subjectiviteit in deze beoordeling komt de transparantie niet ten goede. Tevens wordt de interpretatie van de accountantsverklaring door het maatschappelijk verkeer bemoeilijkt. Dit zal wellicht leiden tot het vergroten van de expectation gap tussen hetgeen de accountant biedt en dat wat het maatschappelijk verkeer van hem verwacht;

- de controle van de jaarrekening.

De kwaliteit van de Administratieve Organisatie en het systeem van interne beheersing is van groot belang bij de risico-inschatting die de accountant moet maken bij de bepaling van het gecombineerde risico. Stel dat accountants tot gelijkluidende antwoorden zouden komen bij vergelijkbare systemen van Administratieve Organisatie. In dat geval zal uitsluitend de risicobeleving van de individuele accountant van directe invloed zijn op de verschillen in hoeveelheid werkzaamheden die uitgevoerd moeten worden om een deugdelijke grondslag voor de accountantsverklaring te verkrijgen.

Zoals geconcludeerd is in paragraaf 1.2.3. wordt het vakgebied van de Administratieve Organisatie gerekend tot éen van de componenten van de 'common body of 
knowledge' van de accountantsprofessie. Door de grote aandacht die aan dit vakgebied wordt gegeven, zowel in de opleiding als in de dagelijkse praktijk, bouwt de accountant een grote hoeveelheid kennis op, op het gebied van de Administratieve Organisatie. Gebruikmakend van deze kemnis zullen accountants hun oordeel vormen over de kwaliteit van een administratief-organisatorisch proces. Door de grote mate van gelijkvormigheid in opleiding en 'training on the job' in de praktijk mogen gelijkluidende oordelen verwacht worden bij de beoordeling van gelijke administratief-organisatorische processen hetgeen aangeduid kan worden met het professional judgment. Op grond van deze verwachting wordt in deze studie op een drietal onderzoeksvragen antwoord gegeven. De eerste twee onderzoeksvragen hebben betrekking op het professional judgment van de accountants bij het geven van hun oordelen ten aanzien van de aan hen voorgelegde casusstellingen. De derde onderzoeksvraag richt zich op het psychologische profiel wan de accountant, waarbij nagegaan wordt of het profiel van de accountants die betrokken zijn geweest in deze studie afwijkt van profielen van accountants uit andere onderzoeken.

Professional judgment wordt bekeken vanuit een tweetal invalshoeken; enerzijds vanuit de individuele accountant en anderzijds vanuit de accountantsprofessie. In het eerste geval, benaderd vanuit de individuele accountant, is sprake van het judgment van de professional. In het tweede geval, vanuit de accountantsprofessie, is sprake van het judgment van de professie. Niet alleen liggen hier duidelijke verschillen, te weten individu versus een collectief, maar tevens is een relatie tussen beide optieken te onderkennen. Van Eijkelenburg [2001] gat hierop in door de relatie te benaderen vanuit de argumentatietheorie. Hij stelt daarbij dat de kwaliteit van de professionele oordeelsvorming in het algemeen afhankelijk is van een kritische discussie tussen collega-professionals. Het judgment van een professional spruit weliswaar voort uit de geest van de individuele professional, maar de kwaliteit ervan is ter beoordeling van een kritisch publiek gevormd door zijn collega-professionals en verzameld in de prow fessie. Van Eijkelenburg [2001] vat in zijn betoog over de vraagstelling of professional judgment een eigen mening impliceert, en derhalve bezien dient te worden vanuit een professional, zijn visie kernachtig samen door te stellen dat:

'zolang een mening niet is geëxpliciteerd deze oninteressant is voor de professic doordat deze niet bekritiseerbaar is en dat indien deze wel is geëxpliciteerd, beargumenteerd en aamward door de professie, het geen eigen mening meer is'.

Hiermee benadrukt Van Eijkelenburg [2001] dat het judgment van de professie dus meer is dan het judgment van een individuele professional; het is de representatie van het geheel van oordelen gegeven door het collectief van individuele professionals behorende tot een specifieke professie. In de onderhavige studie wordt professional judgment bezien vanuit deze optiek, dus: de consensus in de oordeelsvorming door 
de individuele accountants. Het begrip professional judgment is geconcretiseerd in de vraagstelling: in hoeverre geven individuele accountants bij de beoordeling van gelijke administratief-organisatorische processen een gelijkluidend oordeel. Met andere woorden: wat is de mate van consensus in de door de individuele accountants gegeven oordelen omtrent gelijke administratief-organisatorische processen.

Zoals in paragraaf 2.4. mader uiteengezet wordt, kan consensus gezien worden als een proxy voor de kwaliteit van professional judgment. Deze proxy vervangt het ontbreken van de normatieve criteria voor de evaluatie van het oordeel van de accountant aangaande administratieve processen [Johnson, Jamal en Berryman, 1989]. Door het meten van consensus van deze oordelen kan een antwoord worden gegeven op de eerste onderzoeksvraag:

V1: Komen accountants bij de beoordeling van gelijke administratief-organisatorische processen tot gelijklwidende oordelen?

Zoals in paragraaf 1.2.2. is gesteld, is de verschijningsvorm van het systeem van Administratieve Organisatie situationeel bepaald. Bij de vormgeving van het systeem van Administratieve Organisatie door het management, wordt een keuze gemaakt uit een groot aantal administratief-organisatorische procedures en maatregellen van interne beheersing. Richtinggevend voor de keuze die het verantwoordelijk management makkt ten aanzien van deze mix zijn niet alleen persoonlijke voorkeuren maar ook de karakteristieken van de onderneming zelf.

Het systematisch gebruik van gegevens en informatie ontwikkelt bij individuen een 'relatief begrip van belangrijkheid' van die gegevens en informatie. Dit relatieve begrip van belangrijkheid komt tot uitdrukking in de ordening van subjectieve gewichten die aan de gegevens en informatie worden gegeven en die het belang van ieder gegeven ten opzichte van elkaar uitdrukt; samen vormend een 'prototypisch mentaal model'. Een prototypisch mentaal model is een gestructureerde weergave van de door instructie, ervaring en aanleg opgebouwde kennis voor de uitvoering van een specifieke taak. Anders gezegd, het prototypisch mentaal model wordt gezien als de resultante van het gehele proces van taakgerichte kennisopbouw en kenmisstructurering [Dué, 2000; Rosch, 1978; Wright, 1977].

Ook de accountant, die het systeem van Administratieve Organisatie moet beoordelen, ontwikkelt cen prototypisch mentaal model en in die situatie is dit model gericht op administratief-organisatorische procedures en maatregelen van interne beheersing [Wright, 1977]. In dit prototypisch mentaal model heeft de accountant de contingentiefactoren verwerkt die bepalen welke interne beheersingsmaatregelen in de gegeven situatie noodzakelijk worden geacht. Dit prototypisch mentaal model is 


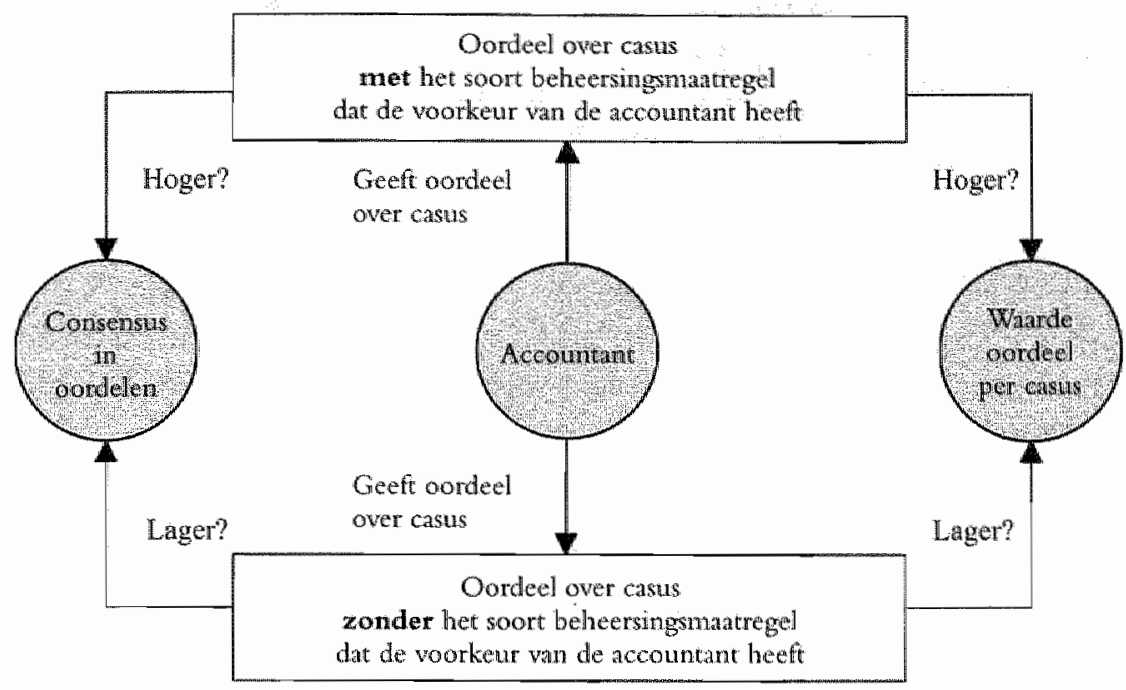

Figutur 1.3: Invloed wan voorkeur wan accountant op wardeoordeel en consensus

geen statisch model en mag door de accountant niet worden veronachtzaamd [Kennedy, 1995]. Het vaker geconfronteerd zijn met een vergelijkbare situatie zal een structurerende werking hebben op het prototypische mentaal model van de accountant. De accountant hanteert dit model als zijn referentiekader waartegen hij de werkelijkheid afzet [Frederick en Libby, 1986]. Hoe beter de werkelijkheid overeenkomt met dit prototypisch mentaal model des te hoger de waardering van de accountant zal zijn. De accountant zal dan ook een voorkeur hebben voor die onderdelen in het prototypisch mentaal model welke de grootste bijdrage aan dat prototypisch mentaal model leveren [Rosch, 1978]. Bij de beoordeling van administratief-organisatorische processen leveren de verschillende soorten beheersingsmaatregelen ieder een eigen bijdrage aan het voor dat doel opgebouwde prototypisch mentaal model. Indien dan over een voorkeur van de accountant voor een soort beheersingsmaatregel wordt gesproken, wordt bedoeld dat soort beheersingsmaatregel die de grootste bijdrage levert aan het prototypisch mentaal model gericht op de beoordeling van administratief-organisatorische processen. De voorkeur van de accountant voor deze beheersingsmaatregelen kan van invloed zijn op het waardeoordeel dat door hem uitgesproken wordt bij de beoordeling van een casusstelling en op de consensus in de oordelen door accountants gegeven. Hiervoor zijn de door de accountant gegeven waardeoordelen in twee groepen onderverdeeld, te weten:

- oordelen door accountants gegeven over casusstellingen met een soort beheersingsmaatregel die een grote bijdrage levert aan het prototypisch mentaal model van de accountant gericht op de beoordeling van administratief-organisatorische processen; hierna weergegeven als de voorkeur van de accountant hebbend; en 
- oordelen door accountants gegeven over casusstellingen zonder het soort beheersingsmaatregel dat de grootste bijdrage levert aan het prototypisch mentaal model van de accountant gericht op de beoordeling van administratief-organisatorische processen; hierna weergegeven als niet de voorkeur van de accountant hebbend.

Door nu de door de accountants gegeven waardeoordelen van beide groepen met elkaar te vergelijken kan de invloed van de voorkeur van de accountant op de gegeven watrdeoordelen en op de consensus wordlen bepaald. In figuur 1.3. zijn deze twee invloeden weergegeven.

Door het onderbrengen van de beoordelingen van accountants (inclusief de door hen aangegeven voorkeuren) in verschillende onderzoeksgroepen kan antwoord gegeven worden op de tweede onderzoeksvraag:

V2: Is de voorkeur van de accountants voor een bepaald soon beheersingsmatregel pan invloed op de consensus in de oordelen?

In de voorgaande paragrafen is een ontwikkeling geschetst van de wijze van controleren; van meer gegevensgericht naar meer systeemgericht. Ingegeven vanuit maatschappelijke ontwikkelingen neemt de accountant steeds meer kennis van de bedrijfs-en administratief-organisatorische processen. In het kader van de controle van de jaarrekening baseert de accountant zich op het goed functioneren van deze processen en de daarin opgesloten maatregelen van interne beheersing [Gortemaker, Bindenga, Ten Wolde, Van Kollenburg, Wieleman, Krom, Dassen, Coster en Van Sluis, 1998]. Voorts wordt de accountant steeds vaker gevraagd een oordeel te geven over de kwaliteit van deze processen in het kader van corporate governance welke tendens zich naar verwachting zal doorzetten [AICPA, 2004; PCAOB, 2004, 2003; Tabaksblat, 2003; Sarbanes-Oxley Act, 2002; Winter, Garrido Garcia, Hopt, Rickford, Rossi, Schans Christensen en Simon, 2002; Gregory en Simmelkjaer, 2002].

De accountant ontwikkelt zich tot een expert op het gebied van bedrijss- en administratief-organisatorische processen, vanwege het feit dat:

- het vakgebied Administratieve Organisatie tot één van de kernvakken in het curriculum van de accountantsopleiding behoort [Vaassen en Beek, 1997] en

- de controlemethodologieèn die door de accountants worden gehanteerd bij de controle van de jaarrekening uitgaan van het steunen op de werking van de Administratieve Organisatie [Gortemaker, Bindenga, Ten Wolde, Van Kollenburg, Wieleman, Krom, Dassen, Coster en Van Sluis, 1998; Eimers, Biggs en Mock, 1997 ] en 
- de corporate governance-discussie steeds meer aan de accountant vraagt een oordeel te geven over de kwaliteit van de Administratieve Organisatie.

Met betrekking tot de inrichting van de administratief-organisatorische processen zal de van oudsher bestaande natuurlijke adviesfunctie van de accountant zich verder op het gebied van de inrichting van de administratief-organisatorische processen ontwikkelen. In aansluiting op een door Schloemer en Schloemer [1997] uitgevoerd onderzoek kan door het afnemen van psychologische testen een antwoord worden gegeven op de derde onderzoeksvraag:

V3: Wijkt het psychologische profiel van de accountants die meegewerkt hebben aan deze studie af van dat van accountants die hebben meegewerkt aan andere soortgelijke studies?

\subsection{Relevantie van dit onderzoek}

De vraag naar een grotere mate van transparantie zal ongetwijfeld haar weerslag vinden in de accountantsprofessie. Een eerste aanzet hiervoor is gegeven in de in Amerika uitgevoerde studie door het 'Panel on audit effectiveness' (hierna 'Panel') [Public Oversight Board, 2000] en de openbare 'hearings" die naar aanleiding van de rapportage zijn gehouden. De activiteiten die door het Panel worden ontplooid zijn transparant en voor een ieder te volgen via de website van het Panel ${ }^{39}$. Daarnaast is een extra aanzet gegeven door de op 25 juli 2002 van kracht geworden Amerikaanse nieuwe wet 'The Sarbanes-Oxley Act 2002' [Sarbanes-Oxley Act, 2002].

Op grond van de huidige maatschappelijke ontwikkelingen zal de accountant veel transparanter moeten gaan werken. Veel meer dan voorheen zal de accountant rekenschap moeten geven over de wijze waarop een oordeel tot stand komt. Ook zal het oordeel zelf veel duidelijker moeten worden. Momenteel is de bewoording van de accountantsverklaring gestandaardiseerd [NIVRA, 2003; [FAC, 2004a]. Het oordeel van de accountant is veelal gebaseerd op een uitgevoerde risicoanalyse zonder dat de wegingsfactoren die daarbij zijn gehanteerd in het oordleel expliciet tot uitdrukking komen. Zoals uit de rapportage van het Panel blijkt hebben zij nog wel vertrouwen in de risicobenadering zoals weergegeven in het audit risk-model. Het Panel vindt evenwel dat dit model, gelet op de snelle ontwikkelingen in de maatschappij, regelmatig op actualiteit getoetst moet worden. Dit wordt eveneens bevestigd door de opstelling en de strekking van het framework dat is uitgebracht door de IFAC inzake assurance services [IFAC, 2003b; Gregory en Simmelkjaer, 2002; Sarbanes-Oxley Act, 2002; Public Oversight Board, 2000].

De ontwikkeling gericht op het transparant maken van de werkzaamheden van de accountant makt het mogelijk dat benchmarks worden opgesteld waardoor indivi- 
duele accountants met elkar vergeleken kunnen worden. Niet alleen kunnen de uitkomsten van de werkzaamheden, de oordelen, onderling vergeleken worden maar ook de wijze watrop deze oordelen tot stand komen. Voor wat betreft de controle van de jarrekening is deze ontwikkeling gericht op transparantie al deels zichtbaar. Via verschillende publicaties en lezingen mag de inhoud van de methode van controleren van de jaarrekening, gebaseerd op de kwaliteit van de Administratieve Organjsatie, als bekend worden beschouwd.

Anders ligt dit voor de overige assurance services die de accountant pleegt te verstrekken. Één van die assurance services is het geven van een oordeel over de toereikendheid van een beheerssysteem binnen een organisatie. In het kader van de corporate governance-discussie zal een organisatie altijd streven naar een zo positief mogelijk oordeel van de accountant aangaande kwaliteit van de administratief-organisatorische processen. Het maatschappelijk verkeer is er niet bij gebaat indien organisaties voor het verkrijgen wan een zo positief mogelijk oordeel gaan 'shoppen'. Het is dus in het belang van het maatschappelijk verkeer dat accountants bij de beoordeling van vergelijkbare beheerssystemen tot overeenkomstige oordelen komen. Hierin ligt nu de relevantie van deze studie.

Onderzoeken die gericht zijn op het inzichtelijk maken van het professional judgment bij accountants zijn niet alleen van belang voor de accountantsprofessie als geheel, maar evenzo voor de individuele accountant. De accountantsprofessie kan daamee aantonen dat zij beschikt over een grote mate van robuustheid hetgeen impliceert dat ongeacht welke accountant een onderzoek uitvoert, het oordeel niet subjectief beinvloed zal worden, in materielle zin bezien. De individuele accountant kan bij zijn oordeelsvorming steunen op het binmen de accountantsprofessie geldende professional judgment.

Het inzicht in het professionaljudgment wan de accountant kan tot het aanpassen van het curriculum van de opleiding tot accountant aanleiding geven. Juist die extra andacht voor elementen die van belang zijn voor het professional judgment van de accountant bij de beoordeling van een systeem van Administratieve Organisatie, is van groot belang. Mede gelet op de grote betekenis van dit oordeel voor zijn verklaringen en mededelingen bij verantwoordingen.

Het matschappelijk verkeer kan de uitkomsten van deze onderzoeken gebruiken bij de beoordeling van de individuele accountants en kan zodoende haar wet-en regelgeving op de uitkomsten van deze onderzoeken afstemmen. Uitkomsten van dit soort onderzoeken kunnen dienen als toetssteen. Ook kunnen ze als objectieve matstaf gehanteerd worden bij de kwaliteitstoets op de oordelen van accountants. De individuele accountant is hiermee gebat. Wanneer de kwaliteit van de geleverde arbeid door het matschappelijk verkeer objectief kan worden beoordeeld wordt de 
kwaliteit tussen de accountants onderling vergelijkbaar. Hierwoor is het hebben van een normenkader onontbeerlijk. Door het witvoeren wan dit soort onderzoeken kan een bijdrage aan dit normenkader worden geleverd. Deze bijdrage ligt besloten in adequate criteria genoemd in het International Framework for Assurance Engagements en de International Standard on Assurance Engagements (ISAE 3000) [IFAC, $2003 \mathrm{~b} ; 2003 \mathrm{c}]$. Hierdoor kan de waarde van de uitingen van accountants in positeve richting beinvloed worden.

De wetenschappelijke relevantie van deze studie is het leveren van een bijdrage aan het wetenschappelijk onderzoek dat gericht is op het inzichtelijk maken van het bestan van professional judgment indien de opleidingen van de in het onderzoek betrokken accountants zoveel mogelijk aan elkaar gelijk zijn. Slechts de training on the job, de opgedane ervaringen en de persoonlijke karakteristieken van de in het onderzoek betrokken accountants verschillen ${ }^{40}$.

\section{Noten}

1 Te noemen zjo onder meer Knechel f2001], Awhton en Ashton [1995]" Libby [1995], Solomon en Shields. [1995]. Bindenga [1993], Libby en Luft [1993], Vaassen [1993], Bonnen [1991], Choo en Troman [1991], Trotman en Wood 1991], Colbert [1989], Choo [1989], Van de Poel en Vaassen [1988, Abdolnohammadi en Wright [1987], Fredenick en Libby [1986], Ashton [1983].

2 Te noemen zin Worldcom, Xerox, Enron, Global Crosing, Adelphia Communications, HIH, Viwendi, HealthSouth, Tyco, ImClone, Omnicom, Pamalat, Mirror Group Newspapers en Ahold [Swinkels, 2003; Leonard, Lindsell en Turley, 2003; MFAC, 2003d]

3 Op 29 juli 2002 is door de Amerikatanse president een riteuwe wet ondertekend "The Sarbanes-Oxley Act 2002"

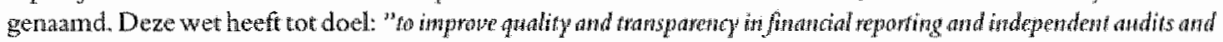

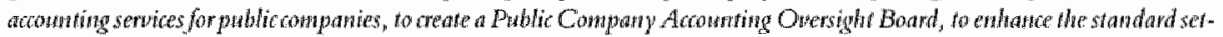

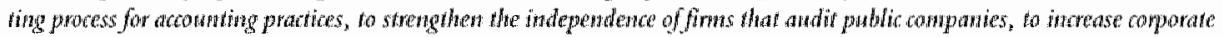

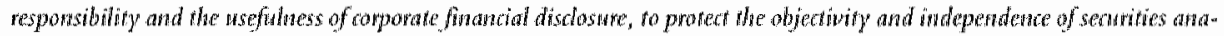

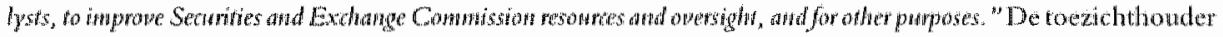
wan de Amerikanse beurs, de Securites and Exchange Commission (SEC), is een grote rol gegeven bij de andere in wulling wan deze wet.

4 Zonder üputtend te zijn, zijn te noemen op het internationale wak de onderatak an en publicaties wan onder" meer Roberts en Dillard-Eggers [2003]. Hastie [2001], Knechel [2001], Peecher en Solomon 2001], "Troman [2001], Choo en Curtis [2000], Davis, Kennedy en Manes 2000], Hunton. Wier en Srone 2000], Mascha en Miller [2000]. Bonner [1999]. Mock en Turner [1999], Shelton [1999], Tan en Kao [1999] Ashuon ten Ashton [1995], Libby [1995], Solomon [1995], Solownon an Shields [1995], Bjggss, Bujink, Majoor, Mock, Quadicker en Schilder [1994], Libby en Luft [1993], Bomner en Penmingrton [1991], Bailey [1990], Béd:and [1989], Choo [1989], Colbert [1989], Johnson, Jamal en Benyman [1989], Libby, Artmation Willinghame [1985], Trotuman en Yetton [1985], Scott [1984]. Biggs en Mock [1983], Fellix en Kinney [1982], Libby en Lewis [197\%]. Binnen de Nederlandse protessie zujn eveneens in de afgelopen jaren dit soort onderzoken airgewoerd en gepubliceerd zoals Wan Eijkelenburg [2001], Van Kujjck [1999], Bnugman. van Roosmalicn en Weisfelt [1997], Vaatsta [1996], Vaassen [1993], Wan de Poel en Vaassen [1988].

5 Het Personedszakenproces is gekozen ondat de acconntant bijha bij iedere controle van de jaamekening in de een of andere vom geconfronteerd wordt met dit proces. Alleen in die gevallen watrin binnen de tecontroleren ondememing ger werknemers aan wezig zijn zal hij dit proces niet tegenkomen. Daamast zin binnen het Per-m soneelszakenproces alle administraticf organisatorische functios be onderkemen alsmed te ondememen acties

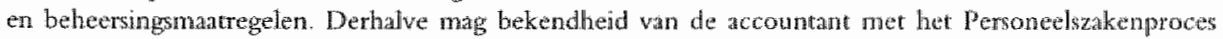
verwacht worden. 


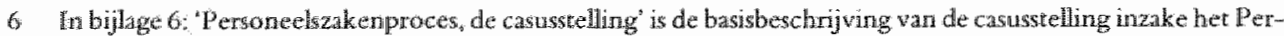
sorteckzak enprocs opgenonen. In bijlage 7: 'Deelprocessen, procedures, activiteiten en beheersing' is een witsplising wergegewen wan de binnen de castustelling te onderkennen deelpuocessen, procedurs, activiteiten en behersing op activiteiten niweat. In bilage 8: "Overzich casustellingen met aanwezige beheersingsmatregelen" is de opbow van dwerschillende casusstellingen met betrekking tot de soorten beheersmatregelen weergegeven.

y Kuteluel [2001] stelt "auditing is firt and foremost a judgment process" (hoofdstuk 15 : Auditor Decision Making: Judgment, Ethics and Legal Liability", pp 591 \%. Hayes, Schildex, Dassen an Wallage [1999] "the awdit process ray be compard to the empirical scientific cycle" (hoofdsuk 1: "Intemational Auditing Overview" pp

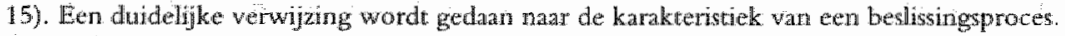

8 Zie Richajin woor de Accountantscontrole 120 artikel 7 , de nadere anduiding (relatiof) is een Nederlandse touvoeging.

9 Date absolute zekeheid bij een controleopdracht niet bereikbar is wordt in de Richtijn woor de Acoun-

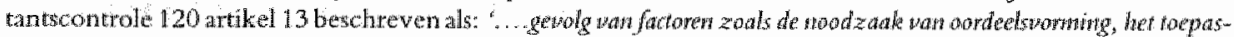

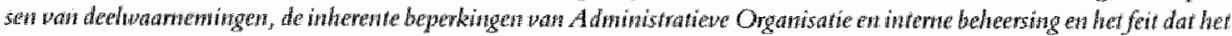

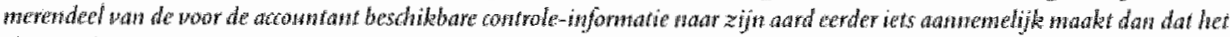
shitesd bewijhmateriad werthoft.

In het recentelik gepubliceerde Framework is dit in artikel 52 net soortgelijke bewoordingen angegeven IFAC, 2003b].

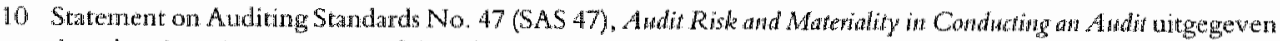
door het American Institure of Certifed Public Accountants [AICPA.2004].

11 International Standard on Auditing 400 (ISA 400), Risk. Assessments and lmernal Control witgegewen door de International Federation of A ccountants. Deze standard blyft van kracht totdat ISA 315 , Undersanding the efriry

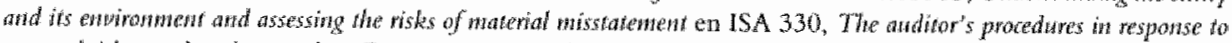
assessed risks van krache worden. Deze worden wan kracht voor alle controles van jaarrekeningen voor periodes startend na 15 decenber 2004 [IFAC, 2004a]

12 Richdijnen vowr de Accountantscontrole 400 (RAC 400), Rsicpanalyse en anlewe behersing, witgegeven door het Koninklijk NIVRA [NIVRA, 2003].

13 In hat publicatie onschrijt het Limperg Instutut het accotuntantscontrolerisico als: de (kwadde) kews, dit de zorg-

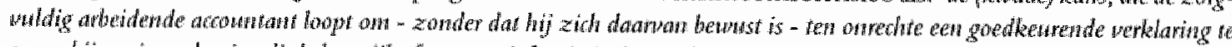

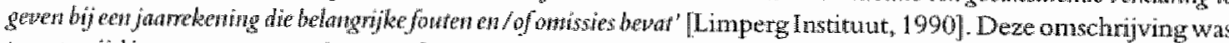

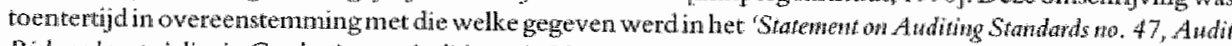
Risk and wateriality in Condwoting an Andit' wan 1983 uitgegeven door het American Institute of Certified Public

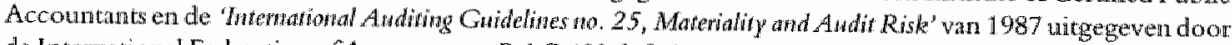
de International Federation of Accountants. RAC 400 definieert "Accountant controlerisico" uls het risico dat de accountant een anjuiste accountantsverklaring verstrekt bij een jarrekening die onjuistheden of onussies vam materied belang bevat. Accountantscontrolerisico is samengesteld uit drie componenten: hat inherent fisico, het interi beheersingsisico an her ontekkingsrisico. Zie RAC 400 artikel 3 [NIVRA, 2003]

14 "Inherent risico" is de gevoligheid van een jasrekeningpost voot cen onjuistheid die afzonderljk of te zamen met onjusthedwen in andere jaarrekeningposten, wan naterieel belaig kan zijn, onder de veronderstelling dat darop geen interne behessingsmattregelen wan toepassing waren. Zie RAC 400 artikel 4 [NIVRA, 2003].

15 "Interne behe rsingsrisio" 0 " is het risico dat een onjustheid, die zich injartekenimgosten kan vordoen en die, atzonderlijk of te zamen nuet onjuistheden in ande re jarre keningposten van material belang kan zijn, nitet tijdig worden voorkonen of ondekt en hersteld door het stelsel van matregelen wan administratieve organisatie an interne behersing. Zie IRAC 400 artikel 5 [NIVRA, 2003].

16 "Ontekkingsrisico" is het risico dat gegevensgerichte werkzamheden wan de accountant exn onjustheid die voorkont in een jaarrekeningpost en die, afzonderlik of te zamen met onjuistheden in andere jarrekeningposten wan materieel belang kan zijn, niet ontdckken. Zie RAC artikel 6 [NIVRA, 2003].

17 Zie hoofdstuk 6.7. Asses Audit Risk, pagina 166 en volgende

18 Richtijn woot de Acountantscontrole 400 artikel 47 zegt hierover vet gedrukt: Hoe hoger de inschatting wan het inherent risico en het interne beheersingsrisico hos meer controle-informatie de accountant dient te verkrijgen vanuit de gegewensgerichte werkzamheden [NIVRA, 2003].

19 Grondslagen en essentele werk lettertype en zijin verplicht on op te volgen c.q. wit te voenen.

20 Zie Ruichtlijn woor de Accountantscontrole 400 artikelen 18 tot en met 22 [NIVRA, 2003]

21. Zie Richtlijn voor de Accountantscontrole 400 artikal 24 [NIVR A, 2003]. 
22. Zie Mock en Tumer 1999$]$ chapter 2 "The Development of Profexional Standards Related to lnternal Accotun" ting Control Evaluation'.

23 De leden wan het "Panel on Audit Efectiveness" en hun foncties tom njde van lun liduritatschap (2000) zijn

- Shatar F. O'Malley, former Chair of Price Waterhouse LLP.

- Dennis H. Chookazan, Chaman Executve Commitae CNA Financial and chairman and CaO mpower;

- Paul Kolton, Chairman Steering Committee, FASB Business Reporting Research Project and former Chatiman and $\mathrm{CEO}$ of the American Stock Exahange:

- Bevis Longstreth, Counsel to Pebevoise en Plimpton and former Conmissioner of the Sectinties anc Exchange Commission;

- Louis Lowenstein, Simon H. Rifkind Profersor Emeritus of Finance and Law, Columbia University;

- Zoe-Vonna Palmose, PricewaterhouseCoopers Professor of Auditing, Univervity of Southern Callifomia:

- Aulana L. Peters, Parmer of Gibson, Dunn en Crutcher and former Commissioner of the Securities and Exchange Commission;

- Ralph S. Saul, former Chamman of the Bord of CIGNA Corponation.

24. Zie chapter 2 "Improwing the conduct of andits" article 2.7 en Appendix A "the audir rak model"."

25 Zie Appendix A pagina 164.

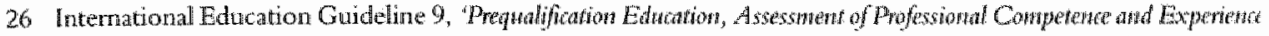

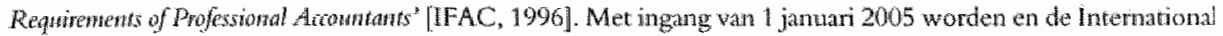
Education Standards van kJacht [IFAC, 2003a]. Deze verwangen de Irternational Education Guacialine 9.

27 Inkernational Education Guideline 9 article 11 [IFAC, 1996]:

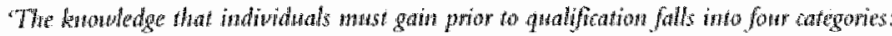

Genewal thandedge;

- Organizational and business knouledge;

- Luforwation vechnology kntouletge;

- Acrounting and arrouning related lanowledges.

Incemational Education Standard 2 anticle 14 [FAC, 2003a]:

The atatent of professional actownting edacation should consist of

" acomnting fonatice and velated kpowledge;

- arganizational and business knowledge; and

- information tedmology knowledge and conperences".

28 Het Framework onderscheidr 'reasonable assurance" en 'lintited asurance' engragements, zie Frannework artikel 56 if 59 [IFAC, 2003b].

29 Zie Framework artikel 20 [IFAC, 2003b]. Op en vrij hoog niveau van abstractie tijn de vijf essentiale kernmero ken van een assurance-opdracht vastgelegd:

- het is een relatie tussen drie partijen, te weten accountant, weran woordelike partijen beoogde gebraikers:

- er is een object van onderzoels.

* er zijn adequate criteria;

- er is adequar betwyismateriat.

* eor sotriftelijle assurace-tapport.

30 Zie het Framework artikel 35 [IFAC, 2003b].

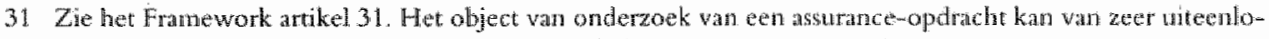
pende aard zijn. Het onderzoek kan betrekking hebben op [IFAC, 2003b]

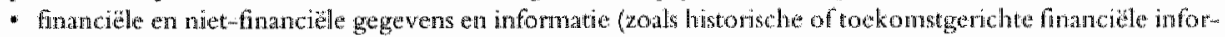

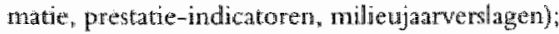

- systemen en processen (zoals interne beheersingwatuegelen):

- gedrag van ondememingen (zoals corpotate governance, de nalewing wan wet- en regelgeving het personeelsbeleid).

32 Zie Framework artikel 34 en ISAE 3000 artikel 21 [IFAC, $2003 \mathrm{~b} ; 2003 \mathrm{c}$. Het opzetten van dergelinke criteria is

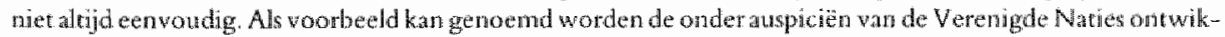
kelde Eco-afficiency indicatoren ten behoeve van sustainability rapportiges [United Nations. 2000 ].

33 Sonus wordt her vak. Administratieve Organisatie ook aangeduid met Bestutrijke Informatieverzorging of Accounting Information Systems. Dit onderscheid is vanut hetperspectef van dit prodschrift niet relevant.

34 IES 2 Content of Professional Accounting Education Prograns, article 14 [LFAC, $2003 \mathrm{a}$.

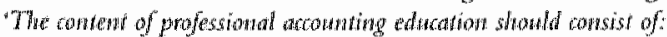

- accounting finance and related knowledge.

- aganizational and business knowledge; and 
- infontation ted nology and comperences".

35 Bjdragen werten gelleverd door:

- Prof J.C.A. Gortemaker RA, voorzitter beroepgrotp accountants Coopers en Lybrand;

- Prof Dr. A I. Binderiga RA, voorzitrer Raad wan Bestuur Moret Enst en Young, voorzitter Bestuur Moret Ernst

- J. ten Wolde RA lid racionale en internationale Audit en Accountancy Commitrex KPMG;

- Prof Drs JCE wan Kollenburg RA, wernoot BDO Campobers Registeraccountants;

- Dr. H.H.H. Wieleman RA, woorzitter Committee on Protessional Standards Arthur Andersen Accountants:

- Drs. J.P. . Kroti RA, lid furopean Professional Affurs Commitea Price Waterhouse;

- Prof. Dr R J.M. Waser RA, partner Deloitte en Touche Regsteracountants.

- Mr. AJ. Coster RA, voorzitter Maatschap Deloikte en Toudhe Registeraccountants;

- M.W. van Sluis RA, vooratter SRA en vennoot Daamen en Van Sluis.

36 Deze bijdragen zijn gebundeld onder de titel 'De rol wan de accotintant, ru en irn de toekomst'.

37 Internal control, conform the "Panel on audit efectiveness" and "Committe of Sponsoring Organizations of the Treadway Commission", consists of fuve interrelated components:

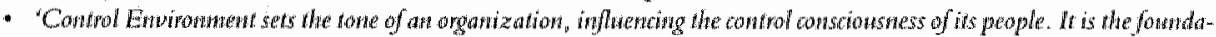
tion for all other cotaponents of internal controf, providing discipline aud structure;

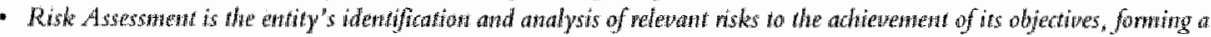
basts for deternibring how risks should be wannged;

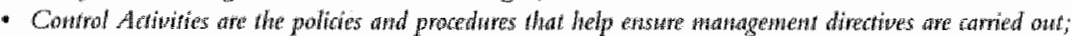

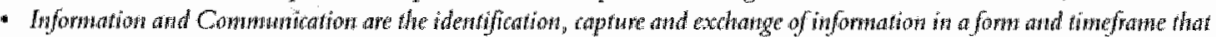
enables peoplo to anry on their responsibifitice;

- Montoring is the process that arses the quality of intenal control performance aver time'.

38 Zie ook artikel var Souting en Spoor [2003]

39 Het website adres is: hop://ww pobauditpanelorg/

40 Dit onderzoek as gericht op her 'aucit process' hetgeen en onderbelicht onderzoeksterrein is volgens een inventarisatie gedari door Majoor, Meuwissen en Quadackers [2000]. 


\section{Voorgaand onderzoek}

\subsection{Inleiding}

In dit tweede hoofdstuk wordt stilgestaan bij een aantal theoretische beschouwingen die naar voren komen in studies over het professional judgment van de accountant en te relateren zijn aan de eerste twee onderzoeksvragen. In de jaren tussen 1970 en 1990 waren deze onderzoeken hoofdzakelijk gericht op de technische aspecten wan de controle. Na 1990 ligt de nadruk op de oordeelsvorming van de accountants ${ }^{1}$ [Van Kuijck, 2000]. Op grond van de uitkomsten van deze onderzoeken heeft Libby [1995] een generiek model ontwikkeld gericht op het oordeelswormingproces van een accountant. Dit model is in een groot aantal studies geadopteerd en in deze studie wordt eveneens dit model als onderliggende structuur gehanteerd. Daarna wordt stilgestaan bij de uitgevoerde cognitieve stijl onderzoeken welke te relateren zijn aan de derde onderzoeksvraag.

Begonnen wordt met een meer algemene beschouwing van het model van Libby. Vervolgens wordt stilgestaan bij de samenstellende delen van het model en de variabelen; zowel afzonderlijk als in hun onderlinge relatie. Daarna wordt een beschouwing gegeven van het begrip professional judgment en worden de resultaten van onderzoeken naar de cognitieve stijl besproken. In hoofdstuk 3 wordt vervolgens ten behoeve van de hypothesevorming op de invulling van dit model voor deze studie ingegaan.

\subsection{Het model van Libby algemeen}

In de afgelopen jaren is veel onderzoek verricht naar de wijze waarop accountants hun oordelen vormen. Veelvuldig is hierbij gebruik gemaakt van uitkomsten van onderzoeken op het gebied van gedragswetenschappen, beslissingstheorieën en de wijze waarop mensen informatie verwerken. Door Libby [1995] werd op grond van de uitkomsten van deze onderzoeken een generiek model voor het oordeelsvor- 
mingproces ontwikkeld. Dit model maakt de aan kennis gerelateerde determinanten wan het door Libby [1995] genoemde 'audit judgment performance', in deze studie vertaald als 'kwaliteit accountantsoordeel', in hun onderlinge verband zichtbaar.

In paragraaf 1.1. is angegeven dat het model van Libby [1995] is ontwikkeld vanuit een tweetal functies, te weten:

$$
\begin{aligned}
& \text { Kwaliteit accountantsoordeel }=f\{\text { Aanleg, Kennis }\} \\
& \text { Kennis }=f \text { Aanleg, Ervaring }\}
\end{aligned}
$$

Het model kent een viertal variabelen, te weten de input variabelen 'Ervaring' en 'Aanleg", de output variabele "Kwaliteit accountantsoordeel' en de "intermediate" output variabele "Kennis". Het model van Libby [1995] is een algemeen geldend model. Echter, er is sprake van een grote verscheidenheid aan opdrachten die door accountants worden uitgevoerd. Deze diversiteit in opdrachten en de daarvoor benodigde kennis, ervaring en aanleg maken een toespitsing van dit model op de uit te voeren opdrachten en eventueel daarin te onderkennen taken noodzakelijk [Hunton, Wier en Stone, 2000, Frederick en Libby, 1986]. Dit impliceert dat voor iedere wit te voeren opdracht c.q. taak het model opnieuw moet worden ingevuld, uitgaande van de voor die opdracht c.q. taak vereiste ervaring, aanleg en kennis. Deze opdrachtafhankelijkheid van het model brengt met zich mee dat de sterkte van de relaties tussen de verschillende variabelen bepaald wordt door de soort opdracht c.q. taak [Hunton, Wier en Stone, 2000; Van Kuijck, 2000; Libby, 1995; Libby en Hunw Tong Tan, 1994; Libby en Luft, 1993].

In deze studie is dit model gehanteerd om en theoretische verklaring te formuleren voor de wijze warop de accountant tot een oordeel komt omtrent de kwaliteit van een specifiek administratief-organisatorisch proces. De gekozen opdracht die het model structureert is: de beoordeling van het personeelszakenproces. Dit proces komt iedere accountant bij de controle van de jaarrekening tegen.

In de volgende paragraaf wordt stilgestaan bij de betekenis van de individuele variabelen en hun onderlinge relaties. Per variabele wordt steeds een definitie van zowe] de variabele gegeven als van de verschillende dimensies die Libby [1995] binnen deze variabele onderscheidt. Vervolgens wordt een korte theoretische beschouwing gegeven over deze variabele en de betekenis daarvan voor het vakgebied Accountancy. Daarna worden achtereenvolgens de input variabelen 'Ervaring' en 'Aanleg' besproken. Dit wordt gevolgd door de 'intemediate'-output variabele 'Kennis' en wordt afgesloten met de output variabele 'Kwaliteit accountantsoordeel'. In para- 
graaf 2.4 wordt ingegaan op het begrip 'Professional Judgment'. Het hoofdstuk wordt afgesloten met een korte samenvatting.

\subsection{Het model van Libby per variabele}

Inzicht in de verschillende variabelen en hun onderlinge relaties, zoals die opgenomen zijn in het model van Libby [1995], is noodzakelijk. Op basis van dit inzicht worden in hoofdstuk 3 keuzes gemaakt ten aanzien van:

- de te verzamelen gegevens en

- de in het onderzoek te betrekken dimensies van de input variabelen.

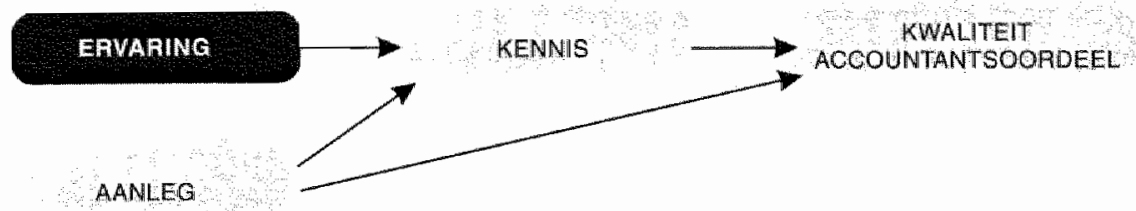

Dit moet weer leiden tot de output variabele 'kwaliteit accountantsoordeel over een specifiek administratief-organisatorisch proces'.

\subsubsection{De input variabele 'Ervaring'}

Definitie volgens Libby [1995]

Libby definieert 'Ervaring' als: de ondervindingen tijdens de uitvoering van opdrachten die de mogelijkheid bieden darvan te leren ${ }^{2}$. Bédard en Chi [1993] geven een definitie die meer gericht is op het presteren in het algemeen en niet alleen op de mogelijkheid die geboden wordt om te leren. Zij stellen dat ervaring eerder cen relatief concept is dan een absoluut concept en adopteren de definitie van Frensch en Sternberg ${ }^{3}$ die stellen dat ervaring een aanleg is, ontwikkeld in de praktijk, om kwalitatief goed te presteren in een specifieke opdrachtomgeving.

Dimensies volgens Libby [1995]

Libby makt een onderscheid in een tweetal soorten ondervindingen, te weten:

1. direct gevelateerde ondervindingen

Hieronder verstaat Libby [1995] alles wat door een individu geleerd kan worden door:

- het betrokken zijn bij de uitvoering van opdrachten;

- het uitvoeren van reviews op opdrachaten uitgevoerd door derden; 
- het verkrijgen van feedback van superieuren op door betrokkene uitgevoerde opdrachten;

- het verkrijgen van feedback vanuit de uitkomsten van de uitgevoerde opdrachten.

Libby [1995] spreekt hier van 'direct' omdat deze ondervindingen direct aan een concrete opdracht gerelateerd zijn.

2. indirect gevelateerde onderwindingen

Hieronder verstaat Libby [1995] alles wat door een individu geleerd kan worden door:

- opleiding en training;

- vaktechnische discussie met collega's;

- studie van formele richtlijnen voor de uitvoering van een opdracht, bijvoorbeeld controlemethodologieën.

Libby [1995] spreekt hier van 'indirect' omdat deze ondervindingen niet aan een concrete opdracht gerelateerd zijn.

In de hiema volgende theoretische beschouwingen wordt nader ingegaan op de input variabele 'Ervaring'. Deze beschouwingen dienen als onderbouwing voor de in het vervolg van deze studie gemaakte keuzes zoals weergegeven in hoofdstuk 3 .

Theoretische beschowwing ten aanzien van de dimensie direct gerelateerde ondervindingen bij de input variabele 'Ervaring.'

Ervaring wordt wak gemeten met behulp van de variabele 'aantal jaren werkzaam in de controle' hetgeen niet in alle gevallen de juiste maatstaf is". Meixner en Welker [1988] maken met betrekking tot deze input variabele een onderscheid in twee soorten van ervaring 5 .

Toegespitst op de accountantsprofessie zijn dit:

1. de ervaring gemeten in 'jaren werkzaam in het accountantsberoep';

2. de ervaring gemeten in 'jaren werkzaam in een specifiek controleteam'.

De lengte van de tweede soort ervaring, zo stellen Meixner en Welker [1988], is daarbij dominant over de eerst soort ervaring.

Bovendien zal de tweede soort ervaring sterker gericht zijn op de door Libby [1995] benoemde direct gerelateerde ondervindingen, dan de eerste soort ervaring.

Bédard [1989] stelt dat ervaring kennis structureert. Deze kennisstructuur wordt in het lange termijn geheugen van de mens opgeslagen en onderhouden hetgeen leidt tot een efficiënter gebruik van het geheugen [Gibbins, 1984]. Uit onderzoek is gebleken dat de strategieën die door professionals gehanteerd worden bij het vergaren van informatie substantieel verschillen van die van de niet-professionals. Deze strategieën nemen voorts minder tijd in beslag en maken daarnaast gebruik van minder informatie [Anderson, 1988]. Naarmate de accountant langer werkzaam is bin- 
nen de accountantsprofessie en daarnaast ook werkzaam is in een specifiek contro team (respectievelijk de eerste en tweede soort ervaring volgens Meixner en Wel [1988]) krijgt hij meer ervaring. Daardoor zal niet alleen zijn kennis toenemen, $\mathrm{m}$ deze kennis ook beter in zijn geheugen georganiseerd worden [Van Kuijck, 201 Bédard, 1994; Bédard en Graham, 1994; Bonner en Pennington, 1991; Béda 1989].

In de afgelopen jaren is de input variabele 'Ervaring' in relatie tot het professio judgment van de accountant veelvuldig object van onderzoek geweest $t^{6}$. Di onderzoeken zijn wooral gericht op de kennis die accountants opdoen in de tijd dat werkzaam zijn bij een accountantsorganisatie; het betreft hier dan de eerste so ervaring volgens Meixner en Welker [1988]. Deze onderzoeken gaan niet in op specifieke aspecten van werkinstructies, interne trainingen en ervaringen welke 1 den tot expert kennis. Onderzoeken die hier wel op ingaan zijn juist noodzakel on de training van de accountants binnen de accountantsorganisaties zo goed mo: lijk te structureren [Bonner en Walker, 1994]. Deze specifieke ervaring, de twet soort ervaring volgens Meixner en Welker [1988], is van vitaal belang in situal waar het professional judgment als complex is te beschouwen [Abdolmohammadi Wright, 1987].

Bonner en Walker [1994] onderzochten verschillende combinaties van werk structies en ervaring. Tevens onderzochten zij de invloed van deze combinaties het opbouwen van kennis die noodzakelijk is voor het uitvoeren van een ratio-al lyse in de fase van het organiseren van de controle. Op basis van hun onderzc komen Bonner en Walker [1994] tot een tweetal conclusies.

$\mathrm{Zij}$ concludeerden dat geen additionele kennis wordt opgeleverd door:

- instructies zonder ervaring;

- instructies samen met praktijksituaties maar zonder feedback.

Op basis van een kritische review van de bestaande literatuur over expertise op vakgebied van de controleleer was Bédard [1989] ook reeds tot deze concllusie get men. Deze auteur stelt dat ervaren accountants meer kennis bezitten en een be gestructureerd kennisbeeld hebben dan beginnende accountants. Tevens bleken verschillen te bestaan in het gebruik van beslissingsprocessen. Davis en Solom [1989] benadrukken dat het belang van feedback voor het leerproces al gedurer decennia wordt erkend. Ook Bonner en Walker [1994] komen tot de conclusie de verklarende feedback op de uitkomsten van praktijksituaties, ("training on job') een belangrijke rol speelt. Zij levert een veel grotere bijdrage aan het kenr beeld van de accountant dan voorschrijvende werkinstructies zonder verklarer feedback ('how-to rules') [Bonner en Walker, 1994]. In alle definities en omsch vingen van het begrip ervaring in hier geciteerde onderzoeken is steeds een ver 
lijkbare tweedeling zichtbaar. Het betreft de indeling theorie versus praktijk of indinect versus direct gerelateerde ondervindingen of werkzam in het accountantsberoep versus werkzaam in een specifiek controleteam.

Aan het feedback vereiste wordt binnen het accountantsberoep voldaan [Bonner en Pennington, 19911. Enerzijds bestaat de verplichting om, nast het afronden van een theoretische opleiding, een door het Koninklijk NIVRA aangestuurde driejarige praktijkstage $^{7}$ te volgen voordat inschrijving in het accountantsregister kan plaatsvinden. Anderzijds vindt naast de verklarende feedback, gericht op een specifiek uitgevoerde opdracht, binnen iedere accountantsorganisatie periodiek persoonlijke beoordelingen plaats. Tijdens deze, meestal jaarlijkse, beoordeling ontvangt de accountant niet alleen feedback op uitgevoerde taken. De accountant krijgt dan eveneens anwijzingen over hoe in de toekomst te werken en te handelen.

Theoretische beschouning ten aanzien wan de dimensie indivect gerelateerde ondenindingen bij de input variabele 'Enaring'

Niet alleen Libby [1995] maar ook Bonner en Walker [1994], Bonner en Pennington [1991], Bonner en Lewis [1990], Marchant [1990] en Bédard [1989] onderkennen dat opleiding en ervaring een zeer sterke relatie kennen. Marchant [1990] stelt dat ervaring de mogelijkheid geeft om iets te leren. Bonner en Pennington [1991] gaan nog verder door op basis van diverse psychologische onderzoeken de conclusie te trekken dat leren voomamelijk plaatsvindt wia het opdoen van ervaring. Daarbij moet aangetekend worden dat enige indicaties bestaan waaruit blijkt dat in sommige gevallen de gegeven instructies de praktijkervaring in belang overstijgen. Dit wijkt af van suggesties die zij hebben waargenomen in onderzoeken op het gebied van accountancy. In die onderzoeken word veelal gesteld dat instructies de basis zijn van het leren. Wel zijn in de psychologische studies sterke aanwijzingen naar voren gekomen dat de instructie vooraf moet gaan aan het opdoen van praktijkervaring. De resultaten van deze studies geven an dat de initiële instructies uitsluitend een bijdrage leveren an het kennisbeeld met een verklarende strekking, de 'declaratieve kennis'. Kennis over hoe de werkzaamheden uit te voeren, de 'procedurele kennis', wordt verkregen door het interpreteren van de declaratieve kennis gedurende de uitvoering van opgedragen taken [Bonner en Pennington, 1991]. Op de verschillen tussen deze twee soorten van kemis wordt in paragraaf 2.3.3. bij de behandeling van de variabele 'Kennis' nader ingegaan.

Accountants beschikken in het algemeen voor het uitvoeren van hun professionele werkzaamheden over een grote hoeveelheid aan informatie. Deze informatie heeft zowel betrekking op de cliënt, diens directe ongeving als op de wijze waarop de controleopdracht uitgevoerd dient te worden. Aangezien zowel de client als diens directe omgeving voortdurend door marktontwikkelingen beïnloed worden, 
moet het accountantsberoep hierop bij voortduring inspelen. Het accountantsberoep kan dan ook worden gezien als een voorbeeld van een levenslang lerende professie.

Accountants ontvangen zowel tijdens hun 'school'-opleiding als na afronding daarvan op talloze manieren instructies. Te denken valt hierbij aan leerboeken en kantoorinstructies maar vooral ook aan adviezen en suggesties van de directe collega's tijdens de uitvoering van de opdracht [Bonner en Pennington, 1991]. Voorts nemen afgestudeerde accountants deel aan zowel intern als extern georganiseerde educatieve programma's. Daarbij wordt opgemerkt dlat de interne programma's worden uitgevoerd door of onder verantwoordelijkheid van hun eigen accountantsorganisatie [Bonner en Walker, 1994]. Bonner en Pennington [1991] betitelen dit soort instructie als de 'formele instructie'. Hiertegenover stellen zij de 'informele instructie', die zij omschrijven als de aan de accountant ter beschikking staande vaktechnisch georiënteerde ondersteunende literatuur. Kennisnemen van deze literatuur betitelen zij als de "informele zelfinstructie'. Aan de indeling van Bonner en Pennington [1991] in 'formele instructie' en 'informele zelfinstructie' kan toegevoegd worden dat deze instructie aanvangt vanaf het eerste moment dat sprake is van een min of meer bewust leven. Dit soort van instructie valt in de categorie 'informele instructie' en wordt betiteld als de 'informele impliciete instructie'.

De tabel in figuur 2.1. is gebaseerd op de studies verricht door Bonner en Walker [1994] en Bonner en Pennington [1991]. Ze representeert het geheel van instructie, toegespitst op het accountantsberoep. Bij de invulling van het model in hoofdstuk 3 wordt hier nader op ingegaan. 


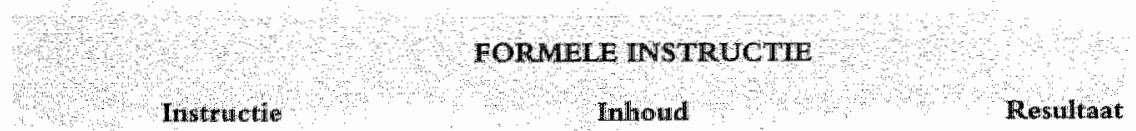

"School-opleiding varar de basis- De inhoud van de leerdoelstel- De resultater van de "school"school tot en riset de afronding wath lingert, het curricuhm en de eind- opleidingen zijn meetbar met het theoretische deel vat de termen liggen vast en zaju bekend behulp wan examens die central accountansopleiding De opletingsinstantives wallen landelijk dan wel decentraal wor-onder het toezicht wan regrelgew den afgenomen. Van belang zijn wende instanties. hierbij de lardielik getentarijnesde examens Administratiese Organsatie en Leer van de Accountantsconfrole.

Verplichte perminente ed incatie
De inhoud van de cursussen valu lende onder het regiem wan de verplichte permanente educatie zijn bekend.

Dit geldi ook voor het door de accountantsongarisaties voongeschreven intern georganiseerd educatief programma.
De restultaten wan de permanente educatie zijn meetbar met behulp van het kwaliteitsbewakingsysteem van de acconntantsorganisaties en net behulp wan "peen'mreviews zoals die zijn ingesteld door de beroepsorganisaties.

Een ander meetpunt is gelegen in de procedures die zich afspelen voor de tuchtredher en in litigation situaties.

\section{INFORMELE INSTRUCTUE}

\section{Inthond}

\section{Restiltaat}

\section{Zelfstudie}

De inhoud van de cursussen zijn. De resultaten zijn slechts meetbaar bekend voor zover deze angebo- indien voor de afronding van the den worden door een extern gew zelfstudie gebruik gemaakt word gariseard educatief programma.

van een "self-assessment" - rest met centrale inzending ter werkrijging van een certiticaat.

Andersoortige telfstudie is niet direct meetbar.

Impliciete instructie

\begin{abstract}
Do inhoud wan deze soort van De regulltaten van dit sooit instrucinstructies is zeer parsoonsgeborim the zijn alleen meetbar indien knden an contextueel bepald. Het is nis bestaat over de persoonlijkdie instructic die de accountant heidstructuren van groteregroepen heeft meegekregen vanuit zijn accotumants. Deze structur kan directe lee fongeving.
\end{abstract}

Figuur 2. 1: Categorisate van soorten instructie (bron: Bonner en Walker [1994] en Bonner en Pennington [1991) 


\subsubsection{De input variabele 'Aanleg'}

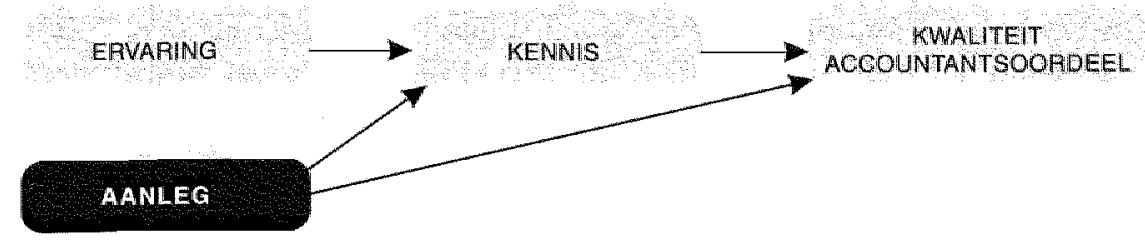

\section{Definitie volgens Libby [1995]}

Libby definieert 'Aanleg' als: de capaciteit om informatieverwerkende taakstellingen uit te voeren, gericht op het oplossen van een controleprobleem ${ }^{8}$.

\section{Dimensies volgens Libby [1995]}

Libby omschrijft deze informatieverwerkende taakstellingen als het geheel van taken gericht op het coderen, het terugvinden en het analyseren van informatie. Libby benoemt hierbij geen dimensies maar verwijst slechts naar het probleemoplossend karakter van het geheel van deze taken.

In de volgende theoretische beschouwing wordt nader ingegaan op deze informatieverwerkende taakstellingen en het aspect aanleg in het algemeen. Deze beschouwing dient als onderbouwing voor de in het vervolg van deze studie gemaakte keuzes zoals weergegeven in hoofdstuk 3 .

Theoretische beschouning ten aanzien van de input variabele 'Aanleg'

De menselijke aanleg als onderdeel van de menselijke intelligentie is een van de meest controversiële zaken in de psychologie. Een grote verscheidenheid aan modellen is ontwikkeld, die primair zijn gericht op de mentale aanleg [Libby 1995$]^{9}$. Deze mentale aanleg draagt bij aan het oplossen van een probleem. Libby [1995] stelt dat de variabele 'Aanleg' kan worden beschouwd als een 'internal state of mind'. Dit wil zeggen dat de aanwezigheid van 'Aanleg' niet rechtstreeks kan worden geobserveerd, maar alleen kan worden afgeleid. Hierbij wordt opgemerkt dat verschillende taken waarschijnlijk steunen op verschillende soorten van mentale aanleg en dan ook nog met een verschillende diepgang [Libby, 1995]. Deze mentale aanleg is deels aangeboren en deels gevormd door ervaringen. Zodoende hoeven niet alle personen met dezelfde ervaring op een bepaald gebied dezelfde aanleg te hebben. De aangeboren mentale aanleg zal bijna altijd verschillend zijn [Bonner en Lewis, 1990].

Bonner en Lewis [1990] verstaan onder deze mentale aanleg: het totaal van het herkennen van causale verbanden, interpreteren van gegevens en het bezitten van een analytisch redeneervermogen. Dit geheel wordt ook wel het algemeen probleem- 
oplossend vermogen ${ }^{10}$ genoemd [Bonner en Lewis, 1990]. In hun studie hebben Bonner en Lewis [1990] zich beperkt tot de invulling van deze mentale aanleg vanuit het algemeen problleemoplossend vermogen [Libby en Hun-Tong Tan, 1994]. Dit uitgangspunt is ook gehanteerd in de studie van Hunton, Wier en Stone [2000]. Zij] hebben het model van Libby gebruikt in een vergelijkende studie naat de performance op thet gebied van management accounting, volgens Vaassen en Beek [1997] een aangrenzende informatiediscipline.

Volgens Libby en Tan [1994] is het van belang om de variabele 'Aanleg' niet alleen vanuit het algemeen problemoplossend vermogen te onderzoeken, maar ook vanuit de in de psychologie onderkende besluitvaardigheid"

Het nemen van een besluit is te verdelen in vijf fasen:

- beschrijven van het probleem;

- kiezen van de te volgen onderzoeksstrategie;

- verzamelen van relevante informatie;

- evalueren van de informatie;

- maken van een keuze;

[Solomon en Shields, 1995; Waller, 1995; Bédard, 1994; Bëdard en Graham, 1994; Bédard en Chi, 1993; Bontz, 1992; Bonner en Pennington, 1991; Pincus, 1990 ; Choo, 1989; Biggs, Mock en Warkins, 1988; Abdolmohammadi en Wright, 1987; Scott, 1984].

Gelet op de overeenkomst tussen het besluitvormingsproces en het probleemoplossingsproces is een invulling van de variabele 'Aanleg' vanuit besluitvaardigheid een andere mogelijkheid. Besluitvaardigheid wordt gemeten met behulp van cognitieve stijlmetingen en meting van de tolerantie voor ambiguiteit [W right en Davidson, 2000; Vaassen, 1993; Chenhall en Morris, 1991; Davis, Grove en Knowles, 1990; Masucli en LaPotin, 1989; Zebda, 1989]. Deze cognitieve stijlmeting en de meting van de tolerantie voor ambiguiteit zijn de instrumenten in deze studie gebruikt om de derde onderzoeksvraag te beantwoorden.

Chenhall en Morris [1991] ontlenen hun omschrijving van cognitieve stijl aan Doktor en Hamilton [1973]: "the way an individual processes, twansfonts and restructures stimuli received from the enviroment to shape a resulting response". Gebaseerd op uitgevoerde cognitieve stijlonderzoeken concluderen Chenhall en Morris [1991] dat de typologie van Jung een zeer goede aanpak is voor onderzoek naar de invloed van de cognitieve stijl op de besluitvaardigheid. De theorie van Jung is een multi-dimensionaal concept dat relaties legt tussen de houding (extraversion or introversion), het waarnemen (sensation or intuition), het oordelen (thinking or feeling) en omgang met de ongeving (judging or perceiving) van een individu [Wheeler, 2001; Briggs- 
Myers en McCaulley, 1990]. Paragraaf 2.5. gaat nader in op de resultaten van onderzoeken die gebruik hebben gemaakt van de theorie van Jung.

Onder tolerantie voor ambiguiteit wordt verstaan: de gevoeligheid van een individu voor onbetrouwbare of dubbelzinnige situaties [Bédard, 1991a, 1991b; Zebda, 1989]. Uit onderzoek, onder meer binnen de gedragswetenschappen, concludeert Zebda $[1989]^{12}$ dat ambiguiteit voorkomt in vele menselijke oordeelsvormingprocessen. Individuen met een hoge tolerantie voor ambiguiteit hebben geen problemen in situaties die niet strikt in twee delen zijn in te delen; zij kunnen gemakkelijk omgaan met de zogenaamde 'grijze' gebieden. Individuen met een lage tolerantie voor ambiguïteit zien dubbelzinnigheid als bedreigend en kunnen moeilijker omgaan met dubbelzinnige situaties [Wright en Davidson, 2000]. Zij zien de wereld in al zijn facetten het liefst dichotomisch, ofwel zwart-wit.

Van een accountant wordt een zekere mate van 'professional scepticism' verwacht bij het uitvoeren wan controlewerkzaamheden. Dat komt onder meer tot uitdrukking in gevoelig zijn voor en kunnen omgaan met inconsistenties en contradicties in de informatie [Libby, 1995]. Dit laatste impliceert een zeker mate van tolerantie voor ambiguiteit. Choo en Trotman [1991] stelden vast dat een significante correlatie bestaat tussen ervaring van een accountant en het aantal gesignaleerde inconsistenties. Libby $[1995]^{13}$ noemt een aantal onderzoeken waaruit blijkt dat ervaren accountants beter inconsistenties en contradicties in de informatie ontdekken dan minder ervaren accountants ${ }^{14}$. 'Professional scepticism' is een mentaal proces. De ambiguiteitwaarde (de mate van tolerantie voor ambiguitteit) kan dan ook worden gezien als een proxy voor 'professional scepticisme'.

In het model van Libby [1995] worden twee relaties met andere variabelen onderkend: een relatie met de 'intermediate"-output variabele 'Kennis' en een relatie met de output variabele 'Kwaliteit accountantsoordeel'. Over de relatie met de variabele 'Kennis' merkt Libby [1995] op dat iedere docent kan bevestigen dat wat een individu leert, recht evenredig is aan diens leermogelijkheden. Het leertempo van een individu vloeit voort uit de wijze waarop hij/zij in staat is een beheersstructuur voor zijn kennis op te zetten en te onderhouden [Minsky, 1986]. Newell [1994] voegt hieraan toe: het begrip 'doelafhankelijkheid' van de te leren objecten. Hiermee wordt bedoeld dat individuen niet snel genegen zijn iets te leren dat zij onder bepaalde omstandigheden niet zouden kunnen gebruiken, dan wel waar zij het doel niet van inzien. Dit 'doelafhankelijkheid'-aspect is terug te vinden in de opleiding tot accountant. Daardoor wordt de verscheidenheid van de leermogelijkheden bij het toetreden tot de accountantsprofessie beperkt [Libby, 1995]. De opleiding tot accountant in Nederland omvat een academisch-economische opleiding, een postdoctorale accountancy-opleiding en een driejarige praktijkstage. De opleiding is, zeker de laatste twee elementen, voomamelijk gericht op de werkzaamheden van de 
accountant en is direct toepasbaar voor de studenten in de praktijk. Daardoor wordt een maximale 'doelathankelijkheid" van de te leren objecten verkregen.

Over de relatie van de variabele "Aanleg" met de output variabele 'Kwaliteit accountantsoordeel merkt Libby [1995] op dat voor het oordeelsvormingproces verschillende soorten aanleg relevant zijn, zoals vaardigheden in het opzetten van redeneringen, mondelinge uitdrukkingsvaardigheden, rekentechnische vardigheden en geheugencapaciteit. De moodzaak voor deze soorten aanleg is afhankelijk van de tak van de accountant [Libby, 1995].

\subsubsection{De 'intermediate'-output variabele 'Kennis'}

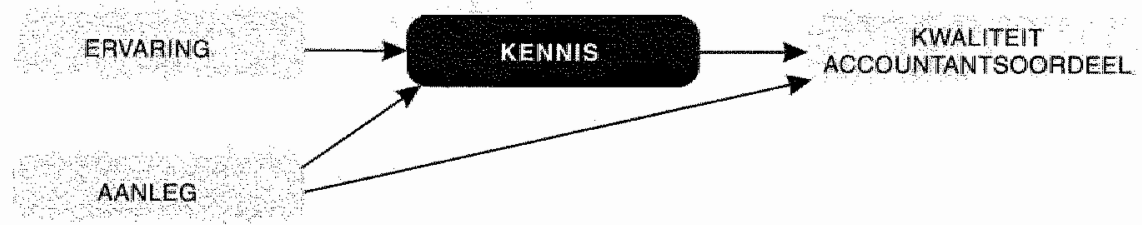

Definitie volgens Libby [1995]

Libby definieert 'Kennis' als: informatie vastgelegd in het geheugen ${ }^{15}$.

Dimensies volgens Libby [1995]

Libby beschouwt de 'intermediate'-output variabele 'Kennis' vanuit twee invalshoeken: een hiërarchische indeling van kennis en het soort geheugen waarin kennis is opgeslagen.

1. Indeling naar hiërarchie van kennis:

- algemene kennis op hoog abstractieniveau ('world knowledge');

- algemene kennis die is gericht op een domein ("general-domain knowledge');

- specialistische kennis die is gericht op een onderdeel van een domein ('subspecialty knowledge").

2. Indeling naar opslag van kennis:

- semantisch geheugen waarin de kennis van concepten, meningen en relaties is opgeslagen (theorie);

- episodisch geheugen waarin de kennis van specifieke ervaringen is opgeslagen (ervaring).

In de volgende theoretische beschouwing wordt nader ingegaan op de variabele 'Kennis'. Door de sterke verwevenheid van de door Libby [1995] gemaakte relatie in kennis en geheugen, worden deze begrippen in deze studie geïtegreerd 
beschouwd. Deze beschouwing dient als onderbouwing voor de in het vervolg van deze studie gemaakte keuzes, zoals weergegeven in hoofdstuk 3.

Theoretische beschontving ten aanzien van de 'intermediate'-output variabele 'Kernis" Zoals hiervoor al is aangegeven, wordt de variabele 'Kennis' binnen het model van Libby [1995] beschouwd als een 'intermediate'-output variabele ${ }^{16}$. Enerzijds wordt de variabele 'Kennis' beinvloed door de inputvariabelen 'Ervaring' en 'Aanleg' en anderzijds beinvloedt de 'intermediate'-output variabele 'Kennis' de output variabele 'Kwaliteit accountantsoordeel'. Libby [1995] onderkent dat kennis een zeer belangrijk element is bij het nemen van beslissingen. Kennis is een 'internal state of mind' en kan daardoor niet rechtstreeks worden geobserveerd. Bruikbare metaforen voor de variabele 'Kennis' kunnen alleen indirect worden getest. Aan de inhoud van de 'intermediate'-output variabele 'Kennis' verbonden conclusies zijn onder meer gebaseerd op verschillen in waanemingen, zoals door middel van:

- herinneren ('recall');

- herkennen ('recognition');

- tijd benodigd on te antwoorden ('response time');

- vergelijkbare hardop-denk-protocollen;

- besluiten die de aanwezigheid van kennis vereisen;

[Choo en Curtis, 2000; Libby, 1995].

Kennis is mede om vorenstaande reden geen eenvoudig begrip en zeker niet bij beschouwing in relatie met accountancy. Nog niet zo lang geleden merkten Bédard [1989] en Bonner en Pennington [1991] zelfs op dat de kennis over de 'intermediate'-output variabele 'Kennis' binnen accountancy nog in het embryonalle stadium verkeert, terwijl volgens Bédard [1989] de accountancy-werkzaamheden juist te typeren zijn als kennisintensief. Bédard en Chi [1993] concluderen, mede op basis van een aantal andere studies ${ }^{17}$ dat een ervaren accountant meer domeinkennis bezit die hij beter clustert dan een beginnend accountant. Op basis van studies in de cognitieve psychologie, nuanceert Bédard [1994] deze conchusie: hij stelt dat bij het uitvoeren van kennisintensieve taken het bezit van een grote hoeveelheid kennis belangrijk is, maar dat de wijze waarop de kennis georganiseerd is nog veel belangrijker is. Om inzicht te krijgen in het begrip kennis en hoe die kennis is gestructureerd, beschouwt Bédard [1994] kennis vanuit twee invalshoeken: de organisatiestructuur en de inhoud van de kennis. Bédard [1994] alsmede Bonner en Walker [1994] en Bonner en Pennington [1991] komen zodoende tot onderstaande indeling ${ }^{18}$, waraan eveneens in latere onderzoeken gericht op het uitvoeren van cognitieve taken wordt gerefereerd [Roberts en Dillard-Eggers 2003]: 
- 'dedarative knowledge" - kennis over theorieën, definities, concepten en feiten met betrekking tot een bepald domein; kennis met een verklarende strekking; het 'kennen';

- 'procedural knowledge" - toepasbare vuistregels c.q. heuristieken, acties danwel manipulaties die valide zijn binnen een bepaald domein; kennis gericht op hoe de werkzaamheden uitgevoerd moeten worden; het 'kunnen'.

Bonner en Walker [1994] stellen wel dat declaratieve kennis aanwezig moet zijn voordat de procedurele kennis gevormd kan worden. Het verschil tussen deze twee soorten kennis wordt ook wel eens vergeleken met het verschil tussen gegevens en processen [Bonner en Walker, 1994].

Voor de in het geheugen opgeslagen kennis zijn diverse organisatiestructuren ontwikkeld [Abde]-Khalik en Solomon, 1988]. Frederick [1991] onderkent daarin twee basisindelingen: enerzijds een indeling die uitgaat van een schematische weergave en anderzijds een indeling die uitgaat van de categorisatieprincipes zoals beschreven door de psychologe Rosch [1978]. Beide indelingen zijn evenwel hiërarchisch van aard.

Libby [1995] theeft zijn hiërarchische kennisindeling ontleend aan de hiërarchische schematische organisatiestructuur van Bonner en Lewis [1990], te weten:

- 'world knowledge' - alle kennis die een individu heeft, ook wel additionele kennis genoend. Deze kennis wordt niet alleen opgedaan door opleidingen en werkervaring, maar wordt ook opgebouwd vanuit andere persoonlijke ervaringen die ieder individu opdoet gedurende zijn leven. Dit soort kennis zal dus per individu verschillen, zelfs bij individuen met dezelfde opleiding en dezelfde werkervaring.

- 'general domain knowledge' - een opsplitsing van de 'world knowledge' in formele verzamelingen, bijvoorbeeld kennis over rechten, psychologie of economie. Deze kennis wordt vooral opgedaan door het volgen van opleidingen en het krijgen van ervaring.

- 'subspecialty knowledge' - een opsplitsing van de 'general domain knowledge' in formele subverzamelingen, bijvoorbeeld kennis over civiel recht als subverzameling van de 'general domain knowledge' rechten.

Wanneer kennis wordt aangesproken zal daarbij altijd een aantal elementen vanuit deze drie niveaus betrokken zijn [Bonner en Pennington, 1991]. Het is echter niet zo dat alle elementen een even grote bijdrage hebben in de uiteindelijke uitvoering van de taak warrvoor de kennis wordt anngewend [Frederick en Libby, 1986].

Bédard [1994] heeft bij de hiervoor gegeven indeling (in declaratieve en procedurele knowledge) de declaratieve knowledge gecombineerd met de indeling van opslag van kennis volgens Libby [1995]. Deze combinatie kan ook plaatsvinden voor de 
'procedural knowledge'. De op basis hiervan te beschrijven kennissegmenten vallen dan op hoofdlijnen uiteen in:

- kennis met een verklarende strekking, de declaratieve kennis, en kennis hoe de werkzaamheden uit te voeren, de procedurele kennis [Bonner en Pennington, 1991];

- conceptuele en niet tijdgebonden inhoudelijke kant van kennis, de semantische kennis, en de tijdgebonden inhoudelijke kennis, de episodische kennis [Bédard, 1994].

Door de indeling van Bonner en Pennington [1991] te combineren met de indeling van Bédard [1994] ontstaan de volgende vier kennissegmenten:

1. 'declarative knowledge', het kennen:

1.1. 'semantic declarative knowledge'

1.2. 'episodic declarative knowledge'

2. 'procedural knowledge', het kunnen:

2.1. 'semantic procedural knowledge'

2.2. 'episodic procedural knowledge'

In figuur 2.2 worden de karakteristieken van de vier kennissegmenten weergegeven. De invulling heeft plaatsgevonden voor het kennisdomein, weergegeven in de hiërarchische kennisindeling zoals door Libby [1995] en Bonner en Lewis [1990] voorgestaan binnen de "world knowledge':

- 'general domain knowledge':

Bedrijfseconomie;

- 'subspecialty knowledge':

Administratieve Organisatie.

Zoals al werd aangegeven is het niet mogelijk om de 'intermediate'-output variabele 'Kennis' direct te observeren. Het effect dat de 'intermediate'-output variabele 'Kennis' heeft op de output variabele 'Kwaliteit accountantsoordeel', kan dan ook alleen worden bepaald vanuit de output variabele. Hiervoor moet worden nagegaan in hoeverre de kennis en aanleg van de accountant passen op diens specifieke taak en de prestaties op die taak [Libby, 1995].

Zoals in hoofdstuk 1 al naar voren is gebracht neemt de beoordeling van administratieve organisatie en de daarin begrepen interne beheersingsmaatregelen een centrale plaats in bij de controle van de jaarrekening. Dit is een logisch gevolg van de maatschappelijke ontwikkelingen en de invloed van de regelgevende en toezichthoudende instanties. Hierdoor mag verwacht worden dat een grote mate van standaardisatie heeft plaatsgevonden op het niveau van de declaratieve kennis (kennis met een verklarende strekking) voor het kennisdomein. Op basis van deze min of meer gestandaardiseerde declaratieve kennis zijn tal van, al dan niet geautomatiseerde 


\author{
"declarative \\ knowledges" \\ hiet "Kennan": \\ dieorteann \\ definities, \\ comcepten an \\ feiten.
}

\section{'procedural knowledge"}

hett 'kumnen': vuistregels en heuristieken
Stemanito knowledge gehougen woot theoretische kennis

"swemantic declarative kmowledge":

* algemean geldend

- theorecisch conceptueel

- thieoretiath validerbar

- theoretisch verklarende kemnis woor het oondeslswormingproces van alle leden behorende tot accountantsprofessic

- riter tijdgeboriden.

Gevormd vanuit de theoretische leerboeken zoals opgenomen in het curriculum wan de opleiding tot accountant en gebaseerd op de International Education Gudelines nummer a en 11 uitgevandigd door de International Federation of Accountants [IFAC, 1996]

"semantic procedural knowledge":

- algemeen toepasbare nitwoeringscon cepten

- kemois afgeleid vanuit de decharatieve kemris

- praktisch toepasbare kennis opgebouwd wantuit ervaringen van accowntants in do praktijk werkzan in het kennisdomenn met behulp van inducrief redeneren en gebasecrd op declaratieve kemnis 19 . fepisondic knowledge gehengen woor kenmis wit ervaring

"episodic declarative knowledge":

- algemeen geaccepteerd

- praktisch conceptuten

- praktisch valideerbaar

- praktisch verklarende kennis voor het oordeelswormingproces wan alle accountants behorende tot en accountantsorganisatie

- tijdgebonden voor langere periode.

Gevormd warnit de methodologieèn zoals die door de acomutintskantoren zijn ontwikkeld en geimplementeerd an voldoen an de Intemational Standards on Audining uitgewardigd door de International Federation of Accountants, de zogenaminde IFAC standaturden IIFAC, 2004 a].

"episodic procedural knowledge"

- persoonlijk toepasbare titvoeringscon-cepten, henristieken c. $\mathrm{q}$. wustregels;

- kemis opgebouwd vanuit arwaring en direct toepasbar

- praktisch toepastura kennis opgebouwd door een individuele accountant door schade en schande en gebruikmakend wan zün direct persoorlijke erwaringen in het kemisdomein.

Gewornd door woor algenten gebruik Gevormd door de wijke walap de indibirnen het kennisdomein ontwikkelde viduele accotintant zijn werkzamheden checklists, templates inlsmede werkpro- in een specifeke opdrachtrelatie uitvoert. grinnana's, geantomatiseerde queries.

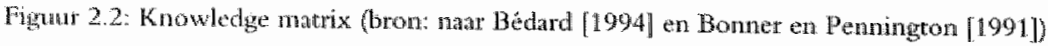

hulpmiddelen ontworpen om de accountant zo veel mogelijk te ondersteunen in zijn streven naar een zo efficiënt en effectief mogelijk uitgevoerde controle. Aangaande het in kaart brengen van administratief-organisatorische processen en de beoordeling daarvan kan onder meer worden verwezen naar flowchart-pakketten en voorgeprogrammeerde standaardprocessen.

Derhalve kan geconcludeerd worden dat ook de semantisch procedurele kennis (conceptuele en niet-tijdgebonden inhoudelijke kant van de kennis hoe de werkzaamheden uit te voeren) redelijk gestandaardiseerd is. Wat rest is de episodische 
procedurele kennis (de tijdgebonden inhoudelijke kant van de kennis hoe de werkzaamheden uit te voeren). Hier komt dat deel van het kennisdomein naar voren dat de individuele beroepsbeoefenaar zelf heeft opgebouwd vanuit, zijn aanleg, eigen persoonlijke ervaringen, door zelfstudie en door impliciete instructie. Samen met de andere meer gestandaardiseerde kennissegmenten en formele instructie wordt zo het prototypisch mentaal model opgebouwd voor de uitvoering van een specifieke taak [Rosch, 1978; Wright, 1977].

\subsubsection{De output variabele 'Kwaliteit accountantsoordeel'}

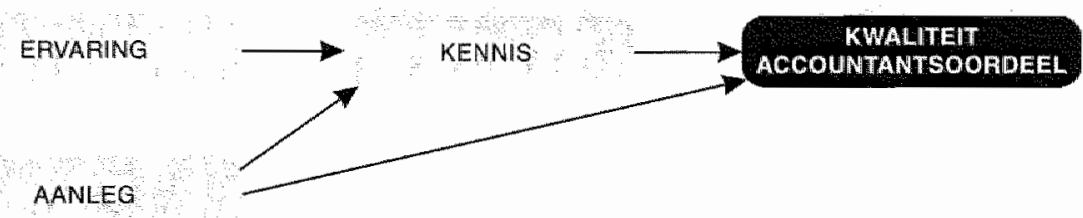

Definitie volgens Libby [1995]

Libby definieert 'Kwaliteit accountantsoordeel' vanuit het begrip performance en komt tot de omschrijving als: de overeenkomst van het oordeel met een criterium ${ }^{20}$.

Dimensies volgens Libby [1995]

Libby maakt onderscheid tussen twee soorten criteria waartegen de oordelen die gebaseerd zijn op uitgevoerde taken (de performance) kunnen worden afgezet:

1. het effectiviteitscriterium, gemeten in de vorm van gemaakte fouten, een statistische norm of oordelen van anderen, zoals een professionele standaard dan wel een consensus met de oordelen wan soortgelijke deskundigen;

2. het efficiency-criterium, gemeten in de tijd die de uitvoering van een taak heeft gekost.

In de volgende theoretische beschouwing wordt, overeenkomstig het vervolg van deze studie, nader ingegaan op het effectiviteitscriterium in relatie tot de output variabele 'Kwaliteit accountantsoordeel'. In deze studie wordt niet ingegaan op het efficiency-criterium van de output variabele 'Kwaliteit accountantsoordeel' aangezien de meting van de tijdsbesteding van het oordeelsvormingproces van de casusstellingen niet in deze studie zijn betrokken. Dergelijke tijdsmetingen moeten objectief plaatsvinden en daarom zou een waarneming ter plaatse minimaal noodzakelijk zijn geweest. Dit was door het grote aantal in het onderzoek betrokken accountants niet realiseerbaar. De hierna volgende beschouwing dient als onderbouwing voor de in het vervolg van deze studie gemaakte keuzes zoals weergegeven in hoofdstuk 3 . 
Theoretische beschouning ten aanzien wan de output variabele "Kualiteit acoumtantsoordeel" Bij de uitwoering van een controle moet de accountant diverse oordelen geven op basis van imperfect bewijsmateriaal, genaamd audit evidence [Frederick en Libby, 1986]. Ashton [1974a, 1974b] stelde jaren geleden al vast dat het codificeren van de wijze warop de evaluatie van het audit evidence plaatsvindt, niet eenvoudig is. Bij de evaluatic van het audit evidence wordt gebruik gemaakt van inhoudonathankelijke" regels, zoals op warschijnlijkheden gebaseerde wetmatigheden en op de inhoud gebaseerde beshutvormingsheuristieken. Alleen ervaren accountants kunnen effectief gebruik maken van deze besluitvormingsheuristieken die gebaseerd zijn op de 'subspecialty knowledge' [Bonner en Lewis, 1990 ] die in paragraaf 2.3.3 worden genoemd. De uiteindelijk verkregen oordelen zijn kennisafhankelijk, zij vereisen een prototypisch mentaal model, zoals hiervoor in paragraf 1.3 is weergegeven, waartegen de werkelijkheid, die is opgebouwd uit allerlei contingentiefactoren, gespiegeld wordt [Frederick en Libby, 1986; Rosch, 1978] ${ }^{21}$. De kwaliteit van het accountantsoordeel is een functie van dit prototypisch mental model en is daarmee positief gecorreleerd. Frederick en Libby [1.986] concluderen dat een dergelijk prototypisch mentaal model een belangrijk mechanisme is dat de variabele 'Kwaliteit accountantsoordeel' beinvloedt ${ }^{22}$. Daantegenover stellen Bédard en Chi [1993] dat accountants niet zulke sterke prototypische modellen zullen hebben doordat iedere cliënt en iedere branche verschillende domeinkennis veronderstelt. Libby [1995] bevestigt dit. Hij wijst erop dat de kwaliteit van een accountantsoordeel takgerelateerd is en het model wan Libby [1995], zoals in paragraaf 2.2 is aangegeven, afhankelijk van die takkstelling moet worden ingericht. Als voorbeeld van het taakgerichte aspect van het model kan verwezen worden naar een onderzoek van Johnson, Jamal en Berryman [1989]. Hieruit bleek dat een accountant met relevante ervaring in een branche beter in stat was een fout als gevolg van fraude te ontdekken dan accountants die deze branchekennis niet hadden.

\subsubsection{Het model van Libby, een conclusie}

Zoals wit het vorenstande blijkt heeft een groot aantal factoren invloed op de kwaliteit van het accountantsoondeel. Ervaring, instructie en aanleg zijn bepalend voor de kennisopbouw van de accountant in de vom van prototypische mentale modellen en de wijze warop hij tot een accountantsoordeel komt. Hierbij moet direct worden opgemerkt dat de variabelen 'Aanleg' en "Kennis' niet direct meetbaar zijn en slechts met behulp van inductief redeneren danwel een proxy kunnen worden vastgesteld ${ }^{23}$.

Bij de evaluatie van zijn verzamelde audit-evidence makt de accountant gebruik van besluitvormingsheuristieken waarbij de accountant de prototypische mentale modellen hanteert als normstelling. De conclusie kan dan ook getrokken worden dat de factoren die van invloed zyjn op de oordeelsvorming van de accountant tezamen 
een complex geheel vormen. Tijdens een oordeelsvormingproces refereert de accountant vaak aan zijn/haar professional judgment. In paragraaf 2.4 wordt bij dit begrip stilgestaan.

\subsection{Het begrip professional judgment}

Op zeer hoog abstractieniveau geven Gibbins en Mason [1988] een initiële definitie van professional judgment, luidend: "Professional judgnemt" is judgment exercised with due care, objectivity and integrity within the framework provided by applicable professional standards, by experienced and knowledgeable people". ${ }^{24}$

Professional judgment kan, overeenkomstig de kwaliteit van het accountantsoordeel uit het model van Libby [1995], gemeten worden met behulp van effectiviteits- en efficiencycriteria [Davis en Solomon, 1989]. Het effectiviteitscriterium heeft betrekking op hoe goed een opgedragen taak is uitgevoerd, het efficiencycriterium heeft betrekking op het gebruik van resources. Uit psychologische studies is naar voren gekomen dat kennis die vergaard is via repeterend werk, het grootste effect heeft op de efficiency-invalshoek [Libby, 1995].

In de afgelopen jaren is veel onderzoek gedaan naar het professional judgment van accountants waarbij de effectiviteit voorop stond ${ }^{25}$. Solomon en Shields [1995] vatten de verschillende onderzoeken samen door ze, in analogie met de indeling van Ashton [1983], in te delen in een framework ${ }^{26}$. De zes evaluatiecriteria die Solomon en Shields [1995] hanteerden bij het testen van hypothesen in het kader van het professional judgment komen sterk overeen met die van Ashton [1983] en zijn weergegeven in de tabel in figuur 2.3 .

Ofschoon al de zes evaluatiecriteria in de diverse onderzoeken zijn gehanteerd bij het testen van de hypothesen, is het meest gehanteerde criterium de 'consensus' [Fink, 1995; Solomon en Shields, 1995; Ashton, 1983]. De keuze voor 'consensus' als hét evaluatiecriterium wijkt af van het evaluatiecriterium dat in psychologische onderzoeken het meest wordt gebruikt: 'accuracy' [Hastic, 2001]. De reden hiervoor is dat binnen de accountantsprofessie eenduidige normatieve criteria ontbreken voor de evaluatie van de oordeelsvorming van de accountant [Johnson, Jamal en Berryman, 1989]. 'Consensus' wordt hierdoor ook wel als een vervangend criterium voor 'accuracy' gezien [Davis, Kennedy en Maines, 2000; Ashton, 1985; Trotman, 1985].

Het grote belang dat aan 'consensus' wordt gehecht, wordt als passend beschouwd aangezien het een belangrijke manier is om een oordeel te rechtvaardigen. Immers verwezen kan worden naar het gelijkluidende oordeel dat door andere professionals 


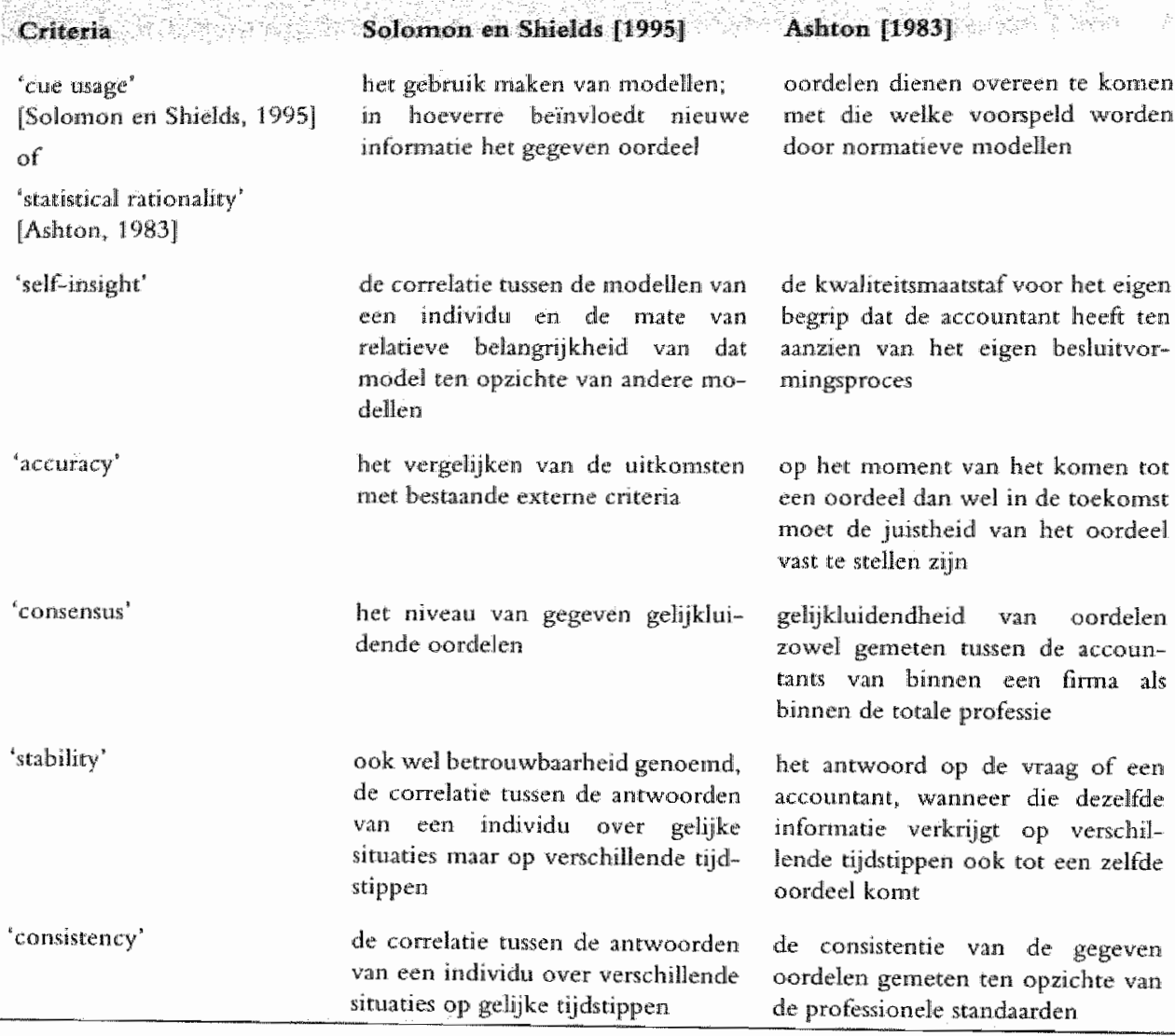

Figuur 2.3: Evaluatiecriteria bij het bepalen van professional judgment (bron: naar Solomon en Shields [1995] en Ashton [1983])

gegeven zou zijn [Solomon en Shields, 1995; Pincus, 1990; Ashton, 1974a, $1974 \mathrm{~b}]^{27}$. Ook in de Nederlandse verhoudingen wordt het belang van 'consensus' onderkend. In het voorwoord van het NIVRA-geschrift nummer 41 [NIVRA, 1986], dat handelt over de vakkundige oordeelsvorming van de accountant, wordt de seelling van Van Hulsentop 28 angehaald welke als waarschuwing beschouwd kan worden. Van Hulsentop stelt dat: de persoonlijke interpretatie en visie van de accountant bij het witvoeren van de controle en het op grond daarvan gegeven oofdeel bij de (toenmalige ${ }^{29}$ ) moderne controlenanpak zo groot zijn dat dit wellicht gevaren kan inhouden voor het accountantsberoep. Hij wijst met name op het risico dat de verschillen tussen de oordelen van de accountants onderling te groot worden, waardoor de 'consensus' verloren dreigt
te raken. 
Zoals in hoofdstuk 1 al is aangegeven kan professional judgment vanuit een tweetal optieken worden benaderd, enerzijds vanuit de individuele accountant (de professional) en anderzijds vanuit de accountantsprofessie. In het eerste geval is sprake van het judgment van de professional, in het tweede geval van het judgment van de professie. Van Eijkelenburg [2001] stelt dat professional judgment meer is dan het judgment van een individuele professional. Het is de representatie van het geheel van oordelen gegeven door het collectief van individuele professionals die tot een bepaalde professie behoren; dus het judgment van de professie. In de onderhavige studie is professional judgment bezien vanuit deze optiek. In de vorige paragraaf is aangegeven dat het accountantsoordeel afhankelijk is van het prototypisch mentaal model dat de accountant als normstelling hanteert en van de wijze waarop de accountant daarmee omgaat, zijn aanleg. Dit prototypisch mentaal model is een gestructureerde weergave van de door instructie, ervaring en aanleg opgebouwde kennis. Eveneens blijkt uit de vorige paragrafen dat de samenstellende delen van de prototypische mentale modellen voor iedere accountant verschillend kunnen zijn. Deze combinatie van prototypische mentale modellen en het hanteren daarvan is richtinggevend voor het professional judgment bezien vanuit de accountantsprofessie.

Aangezien de prototypische mentale modellen en de wijze waarop deze mentaal door de accountant worden gehanteerd niet rechtstreeks waarneembaar zijn, kan 'consensus' van accountantsoordelen, zijnde het niveau van gelijkluidende oordelen [Solomon en Shields, 1995; Ashton, 1983], worden gezien als een proxy voor professional judgment, bezien vanuit het gezichtspunt van de accountantsprofessie. De eerste twee onderzoeksvragen zijn op het bestaan van deze 'consensus' gericht.

\subsection{Cognitieve stijl onderzoeken}

In deze paragraf worden de resultaten van langjarig onderzoek naar cognitieve stijlen weergegeven. Bij het onderzoek naar eventuele veranderingen in de eigenschappen van de accountant is uitgegaan van de theorie van Jung. De theorie van Jung benadrukt dat een persoonlijkheid gevormd wordt door de interactie van de karaktertrekken [Bringhurst, 2001; Wheeler, 2001]. Door Jung zijn deze karaktertrekken samengenomen in een typologie, opgebouwd vanuit een viertal indices waarmee de cognitieve stijl van een persoon wordt omschreven Deze vier indices zijn de basis geweest bij de ontwikkeling van de Myers-Briggs Type Indicator (MBTI) ${ }^{30}$.

Deze paragraafvalt in drie delen uiteen. In het eerste deel wordt een korte samenvatting gegeven van de gehanteerde psychologische testen on de derde onderzoeksvraag te beantwoorden. In het tweede deel worden de resulltaten weergegeven van 
langiarig onderzoek door het Center for Applications of Psychological Type. In het derde deel wordt een samenvatting gegeven van overige cognitieve stijl-studies.

\subsubsection{Gehanteerde psychologische tests}

Bij de theoretische beschouwing ten aanzien van de variabele 'Aanleg' is gesteld dat de wariabele 'Aanleg' niet rechtstreeks te observeren is [Libby, 1995]. De observaties in veel onderzoeken zijn gedaan uitgaande van het probleemoplossend vermogen. Libby en Tan [1994] wijzen erop dat het invullen van de variabele 'Aanleg' vanuit het besluitvormingsproces in plats van het probleemoplossend vermogen eveneens een mogelijkheid is. Een invulling is gevonden in de psychologie alwaar het meten van de besluitvaardigheid plaats vindt met behulp van cognitieve stijlmetingen en meting van de tolerantie voor ambiguiteit [Vaassen, 1993; Chenhall en Morris, 1991; Davis, Grove en Knowles, 1990; Masuch en LaPotin, 1989; Zebda, 1989]. Chenhall en Morris [1991] concluderen daarbij dat de typologie van Jung een zeer goede aanpak is om de invloed van de cognitieve stijl op de besluitvaardigheid te onderzoeken. Een aantal methoden woor het meten van de cognicieve stijl is voor handen ${ }^{31}$. Aangezien de Myers-Briggs Type Indicator gebaseerd is op de theorie van Jung en een grote hoeveelheid cijfermateriaal hieromtrent gepubliceerd is, is deze wijze van meting van de cognitieve stijl voor het onderhavige onderzoek gekozen [University of Florida, 2000; Schloemer en Schloemer, 1997; Briggs-Myers en McCaulley, 1990; Briggs-Myers, 1987].

\subsubsection{Myers-Briggs Type Indicator}

De essentie van de theorie van Jung ${ }^{32}$, welke theorie de basis is geweest voor de Myers-Briggs Type Indicator (MBTI) ${ }^{33}$, is dat schijnbaar toevallige verschillen in gedrag eigenlijk zeer consistent zijn. Ze zijn te herleiden tot de individuele voorkeur voor het 'warmemen' of het 'oordelen'. 'Waarnemen' onvat het geheel van het zich bewust worden van de omgevingsfactoren. 'Oordelen' omvat het gehele proces van het komen tot een conclusie op basis van de warnemingen. Als, zo stelt Jung, mensen systematisch variëren in hun waarnemingen ('waamemen') en in de wijze waarop zij tot een conclusie komen ("oordelen"), dan is het begrijpelijk dat zij overeenkomstige verschillen vertonen in hun reacties, interesse, waarden, motivatie en kunnen [Briggs-Myers en McCaulley, 1990; Briggs-Myers, 1987].

On deze verschillen inzichtelijk te maken kent de $\mathrm{MBTI}^{34}$ een viertal sets van twee bij elkaar behorende indicatoren. Deze sets van indicatoren zijn noodzakelijk om, volgens de theorie van Jung, de voorkeur van een individu voor het "waarnemen' of het 'oordelen' te kunnen bepalen. De voorkeuren geven niet alleen een indicatie waar een individu in een bepaalde situatie aandacht aan geeft, maar ook op welke wijze het individu tot een conclusie kont gebaseerd op wat is wargenomen. 
De volgende vier sets bij elkaar behorende indicatoren worden onderscheiden:

1. 'Extraversion - Introversion (EI)': : de attitude-index;

2. 'Sensing - Intuition (SN)'

: de waarnemingsindex;

3. 'Thinking - Feeling (TF)'

4. 'Judging - Perceiving (JP)'

: de oordeelsvormingindex;

: de voorkeursindex.

In de matrix in figurur 2.4 is in hoofdlijnen aangegeven wat de karakteristieken zijn die achter de verschillende indicatoren liggen [Briggs-Myers en McCaulley, 1990].

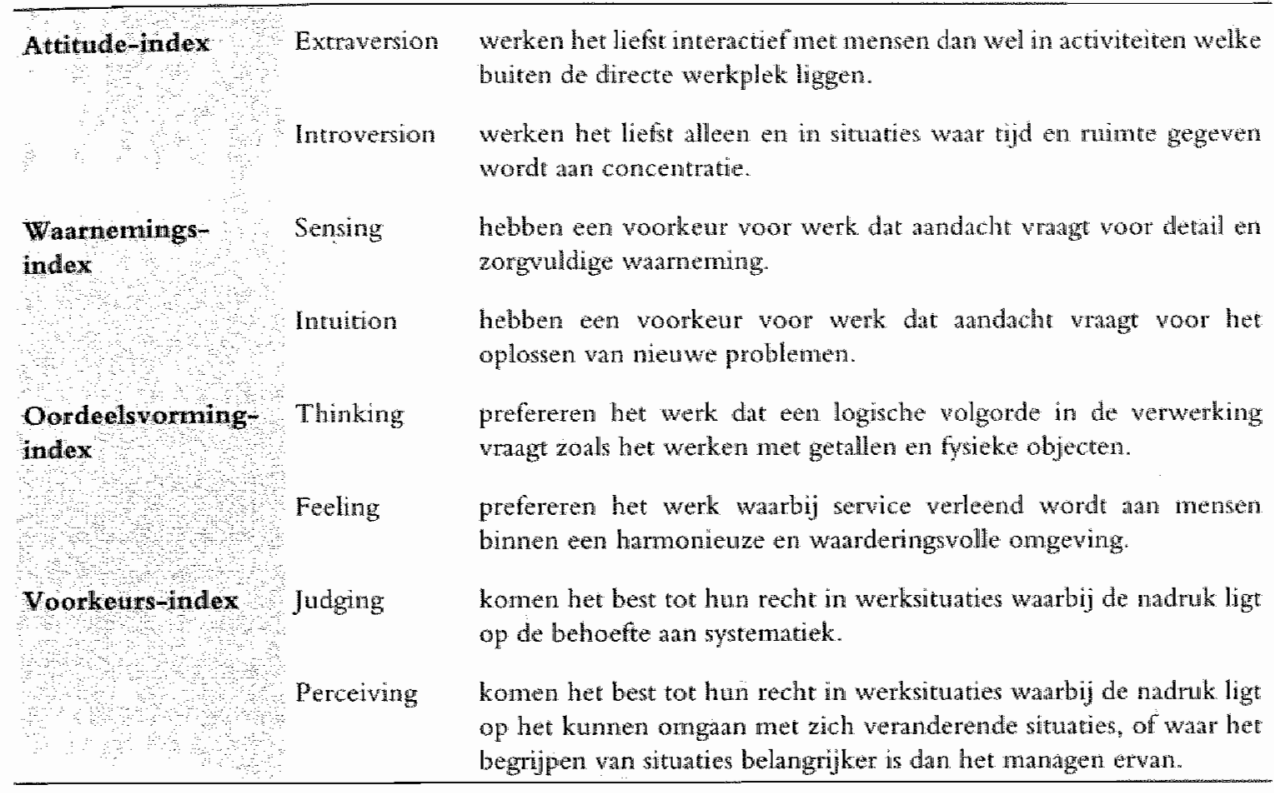

Figutr 2.4: Karakteristieken wan de MBTI indicatoren

De zogenaamde MBTI-types zijn op basis van deze sets van indicatoren geformeerd en geïdentificeerd. Hiervoor vindt een samentrekken plaats van de vier verschillende letters, ieder voorstellend één indicator uit iedere index (zoals ESTJ of INFP) waardoor een zestiental verschillende combinaties ontstaat.

Bij het categoriseren van individuen worden de antwoorden op de gestelde vragen uit de vragenlijst gewogen. Voor iedere indicator binnen iedere index wordt een score berekend, waarna binnen een index de indicator met de hoogste score de classificatieaanduiding weergeeft. Hierbij vertegenwoordigt de letter de richting van de voorkeur binnen een set van indicatoren en het gewicht, zijnde een weerspiegeling van de overwaarde van de indicator met de hoogste score over de laagste, de voorkeursterkte. Een hogere voorkeursterkte geeft aan dat het individu, wanneer daartoe gedwongen, zekerder is in de keuze voor die betreffende voorkeur. 
Ieder individu vormt een voorkeur yoor een bepalde indicator. Het is dan ook logisch dat, zonder verdere sturing van buitenaf, in de gehele ontwikkeling van het individu an die bepalde indicator voorrang gegeven zal worden. Hierdoor kan minder aandacht gegeven worden en energie gestoken worden in het ontwikkelen van de andere indicatoren. Zo zal iemand die zich richt op concrete zaken (het waarnemingsproces via "sensing $\$$ ") zich minder richten op abstracte zaken (het warnemingsproces via 'intuition N'). Het is evenwel een misvatting te denken dat een individu slechts leeft wolgens de principes van zijn of haar favoriete indicator mit de verschillende indices. Volgens de MBTI-theorie leeft ieder individu volgens beide indicatoren uit de attitude-index, alleen kennen ze een favoriet. Zo kan een goed ontwikkeld introvert individu zeer goed werken volgens de extroverte principes, maar werkt hij het best met ideeén en concepten, de principes van de introverte atritude.

Briggs-Myers en McCaulley [1990] benadrukken dat de omgeving waarbinnen een individu gevomd wordt van groot belang is omdat de omgevingsfactoren mede bijdragen aan de vorming van de persoonlijke voorkeur voor indicatoren. Door zijn omgeving wordt het individu gestimuleerd dan wel afgeremd in de ontwikkeling van zijn indicatoren. De ontwikkeling van het type waartoe een individu behoort is derhalve een levenslang proces. Daarbij wordt, mede door de sturing van buitenaf, steeds meer controle verkregen over de persoonlijke voorkeur voor het waarnemingsproces en het oordeelswormingproces en voor de verschillende indicatoren daarbinnen. Juist op deze sturing van buitenaf richt zich de derde onderzoeksvraag. Het is derhalve niet eenvoudig exact te omschrijven wat de karakteristieken zijn van de verschillende combinaties van warnemings- en oordeelsvormingprocessen en de verschillende plaatsen van de indicatoren. Zoals hiervoor reeds is aangegeven, dient niet alleen de plaats van een indicator maar ook de voorkeursterkte die de indicatoren hebben verkregen op basis van de beantwoording van de vragen bij de categorisering te worden meegenomen. Deze voorkeursterkte kan variëren als gevolg wan de ontwikkeling welke het individu doomaakt en de verschillende stimuli waaran hij bloot stat. Ditgehele samenspel van indicatoren is in de MBTI ondergebracht in een systeem van Dynamic Relationships hetgeen werkt volgens het principe dat in het kort is beschreven in bijlage 9: "Myers-Briggs Type Indicator, een leeswijzer" [Briggs-Myers en McCaulley, 1990; Briggs-Myers, 1987].

Door het Center for Applications of Psychological Type (CAPT) ${ }^{35}$ zijn vanaf 1970 gegevens van verschillende beroepen verzameld en bewerkt tot MBTI-types ${ }^{36}$. Hierbij is geconstateerd dat binnen alle beroepen individuen voorkomen behorende tot alle zestien types, mar dat ieder soort beroep in bepaalde types meer en andere minder vertegenwoordigd zijn. 
Bij de oplossing van een probleemsituatie zullen de verschillende indicatoren uit de waarnernings- ( $\mathrm{SN}$ ) en oordeelsvormingindex $(\mathrm{TF})$ als volgt aangewend worden [Briggs-Myers, 1987]:

- 'Sensing' (S) bij het verzamelen van de relevante feiten en het op realistische wijze benaderen ervan;

- 'Intuition' (N) bij het ontdekken van nieuwe mogelijkheden en alle acties welke ontplooid moeten worden om verbeteringen door te voeren;

- 'Thinking' (T) bij de analyse van alle consequenties, goed dan wel slecht, van iedere actie die ondernomen moet worden;

- 'Feeling' (F) bij de bepaling van de waarde, verdiensten c.q. verliezen, van de oplossing voor het individu zelf dan wel voor anderen.

In algemene bewoordingen wordt door de ontwerpers van de MBTI [Briggs-Myers en McCaulley, 1990] de volgende korte karakterschets gegeven van personen met een combinatie van indicatoren behorende tot de waarnemings- en oordeelsvormingindex.

\begin{tabular}{|c|c|c|c|c|}
\hline & -ST & -SF- & $-\mathrm{NF}$ & $-\mathrm{NT}$ \\
\hline People who prefer: & sensing and thinking & sensing and feeling & intuition and feeling & intuition and thinking \\
\hline Focus attention on: & facts & facts & possibilities & possibilities \\
\hline $\begin{array}{l}\text { And handle these } \\
\text { with: }\end{array}$ & impersonal analysis & personal warnuth & personal warmth & impersonal analysis \\
\hline $\begin{array}{l}\text { Thus they tend to } \\
\text { become: }\end{array}$ & $\begin{array}{l}\text { practical and matter- } \\
\text { of-fact }\end{array}$ & $\begin{array}{l}\text { sympathetic and } \\
\text { friendly }\end{array}$ & $\begin{array}{l}\text { anthusiastic and } \\
\text { insightful }\end{array}$ & logical and ingenions \\
\hline $\begin{array}{l}\text { And find scope for } \\
\text { their abilities in: }\end{array}$ & $\begin{array}{l}\text { rechnical skills with } \\
\text { facts and objects }\end{array}$ & $\begin{array}{l}\text { practical help and } \\
\text { services for people }\end{array}$ & $\begin{array}{l}\text { understanding and } \\
\text { communication with } \\
\text { people }\end{array}$ & $\begin{array}{l}\text { theoretical and } \\
\text { tectunical } \\
\text { developments }\end{array}$ \\
\hline
\end{tabular}

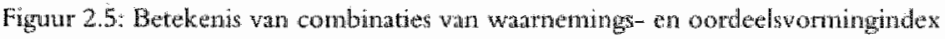

In de onderhavige studie heeft geen onderzoek plaatsgevonden naar de beïnvloeding van het soort type waartoe een onderzochte accountant behoort. Hiervoor is een op het individu toegesneden longitudinaal onderzoek noodzakelijk over een zeer lange tijdsperiode. Deze periode dient te starten op het moment dat het individu zich als student opgeeft om zich te gaan ontwikkelen richting accountant. Op dat moment dient zijn MBTI-type te worden bepaald als een zogenaamde nulmeting. Hierna starten de omgevingsfactoren, zoals de postdoctorale opleiding tot accountant, de opleiding binnen de accountantskantoren als ook de werkervaring bij de cliënten een bijdrage te leveren aan de vorming van de persoonlijke voorkeur voor indicatoren [Briggs-Myers en McCatulley, 1990]. Op verschillende momenten tijdens zijn ont- 
wikkeling dient opnieuw een vaststelling plaats te vinden wan het type en vergeleken te worden met de nulmeting. In deze studie zijn wel de uitkomsten van de psychologische testen vergeleken met de uitkomsten van dezelfde psychologische testen uit andere onderzoeken.

\subsubsection{MacDonald ambiguiteittest}

Naast de hierwoor genoemde meting van de cognitieve stijl heeft in dit onderzoek tevens een meting platsgevonden van de tolerantie voor ambiguiteit. Een duidelijke definitie voor de tolerantie voor ambiguiteit is moeilijk te geven, een eenduidige betekenis van de term ambiguiteit is niet te vinden ${ }^{37}$ [Rydell en Rosen, 1966 ]. MacDonald [1970] geeft als definitie van ambiguiteittolerantie: 'ambiguiteittolevantie is het persoonlijkheidskenmerk aangevende in hoevere en individu problemen heeft met dubbelzinnige situaties c.q. een individu een voorkeur heeft voor verschijnselen die niet eenduidig wit te leggen zijn.'.

Individuen met een hoge ambiguiteittolerantie score hebben geen problemen in situaties die niet strikt in twee delen zijn in te delen, de zogenaamde dichotome situaties. Zij kunnen gemakkelijk omgaan met de 'grijze' gebieden. Voorts munten zij uit bij de uitvoering van complexe taken. Individuen met een lage ambiguiteittolerantie score zien dubbelzinnigheid als bedreigend. Zij zien de wereld in al zijn facetten het liefst dichotomisch, zwart en wit [MacDonald, 1970].

Van belang is dus in hoeverre een individu in staat is om te gaan met dubbelzinnigheden. Intolerantie voor ambiguiteit wordt gelijk gesteld aan autoritair gedrag en vooringenomenheid [Wright en Davidson, 2000; Rydell, 1966; Rydell en Rosen, 1966]. Uit onderzoek dat in de afgelopen jaren heeft platsgevonden, onder meer binnen de gedragswetenschappen ${ }^{38}$, concludeert Zebda [1989] dat dubbelzinnigheid en vaagtheden ("fuzziness') voorkomen in vele menselijke oordeelsvormingprocessen. Fuzziness wordt door Zebda [1989] in dit kader gedefinieerd als: the imprecision and inexactness of words, concepts, events and judgments'. Zebda [1989] trekt de conclusie dat de door hem, mede op basis van de uitkomsten van deze onderzoeken, ontwikkelde "fuzzy set"-theorie van praktische waarde kan zijn voor accountants. Dit geld vooral in situaties watrin modellering van besluitvormingsproblemen plaatsvindt en waarbij dubbelzinnigheid de belangrijkste oorzak is voor onjuistheden en onnauwkeurigheden. Ook Vaassen $[1994 ; 1993]^{39}$ en Van de Poel $[1986]^{40}$ wijzen op verschillende studies op het gebied van psychologie en accountancy waarbij de tolerantie voor ambiguiteit object van onderzoek is geweest.

Door MacDonald [1970] is ten behoeve van de bepaling van de hoogte van de ambiguiteitscore een vragenlijst opgesteld bestaande uit een 20 -tal stellingen die met eens en oneens zijn te beantwoorden. Hij heeft de $\$ 6$ stellingen uit de Rydell-Rosen Ambiguity Tolerance Scale [Rydlell en Rosen, 1966] uitgebreid met twee stellingen 
afkomstig uit de California Personality Inventory, die werd ontwikkeld in 1957 door Gough en twee stellingen afkomstig uit de door Barron in 1953 ontwikkelde Barron's Conformity Scale [MacDonald, 1970]. In dit onderzoek is de zogenaande AT-20 Scale gehanteerd bij de metingen voor de tolerantie van de ambiguitteit. De scores welke gehaald kumen worden met deze meting lopen van een positieve waarde van +20 naar de negatieve waarde van -20 .

\subsubsection{Samematting psychologische tests}

Bij de theoretische beschouwing is ten aanzien van de variabele 'Aanleg" gesteld dat de variabele 'Aanleg' niet rechtstreeks te observeren is [Libby, 1995]. In dit onderzoek hebben een tweetal metingen plaatsgevonden die gerelateerd kunnen worden aan de variabele 'Aanleg'. Het betreft hier een meting van de cognitieve stijl en een meting van de tolerantie voor ambiguïteit. Met betrekking tot de meting van de cognitieve stijl is aansluiting gezocht bij langjarig internationaal onderzoek dat geinitieerd is vanuit de psychologie en gebaseerd is op de theorieën van Jung. Binnen dit onderzoek is de Myers-Briggs Type Indicator gehanteerd welke indicator is gebaseerd op de theorie van Jung. Met behulp van deze indicator kunnen individuen worden gecategoriseerd in types. Ofschoon, in het merendeel van de gevallen, uit onderzoek is gebleken dat alle beroepen vertegenwoordigd zijn in alle types binnen de Myers-Briggs Type Indicator is toch sprake van een zekere voorkeur voor een aantal types. Het Center for Applications of Psychological Type (CAPT) heeft gedurende vele jaren, vanaf 1970 , gegevens van verschillende beroepen verzameld en bewerkt tot MBTI types. In het onderzoek zijn de types uit de onderzoeken van het CAPT als benchmark gehanteerd. Bij de meting van de tolerantie voor ambiguïteit, het al dan niet kunnen omgaan met dubbelzinnigheden, is in dit onderzoek gebruik gemaakt van de AT-20 Scale van MacDonald. De score op deze schaal loopt van +20 , het om kunnen gaan met dubbelzinnige situaties, tot -20 , het gericht zijn op strikt dichotomische situaties.

\subsubsection{Resultaten volgens Center for Applications of Psychological Type samengevat}

Van 1970 tot en met 1984 heeft het Center for Applications of Psychological Type (CAPT) onderzoek gedaan naar de cognitieve stijl van personen werkzaam binnen een groot aantal verschillende beroepen [Briggs-Myers en McCaulley, 1990]. In de beroepsgroep van accountants zijn gegevens van 143 accountants verwerkt tot MBTI-types, zoals weergegeven in bijlage 24: 'MBTI-indicatoren van 143 accountants volgens CAPT'. Daarin is naast een korte beschrijving van de betekenis van iedere index, ook de procentuele verdeling vanuit verschillende imvalshoeken weergegeven. 
Zoals uit de theorie van Jung blijkt komen alle karaktertrekken wel bij iedere persoon voor [Wheeler, 2001], maar verschilt de mate waarin. Uit de genoemde bijlage blijken accountants over het geheel genomen voorkeur te hebben voor "extraversion" (51,04\%), 'sensing' $(56,64 \%)$, 'thinking" $(75,51 \%)$ en 'judging' $(67,84 \%)$, hetgeen weergegeven wordt in de annotatie ESTJ. Indien deze voorkeur geconfronteerd wordt met het procentueel voorkomen van de vastgestelde ESTJtypes binnen de onderzochte accountants blijkt dit type in 15,38\% wan de gevallen voor te komen. Daarme komt het ESTJ-type qua omvang op de tweede plaats. Op de eerste plaats $(20,28 \%)$ stat het type ISTJ. Drie van de vier indexen zijn evenwel hetzelfde ${ }^{41}$. De afwijking betreft in de attitude-index, extravert in plaats van introvert, en bedraagt slechts $4,25 \%$. Veel groter zijn de verschillen tussen de andere indicatoren. Vooral uit de samenvatting van Wheeler [2001] $]^{42}$ blijkt de grote mate van overeenkomst tussen de twee typen. De accountant behoort, met in total 46,14\% van de in het onderzoek betrokken accountants, tot het ST-type, het zogenaamde praktische en op feiten gerichte type met een onpersoonlijke oordeelsvorming. Het ST-type steunt voor het waarnemen van feiten primair op de zintuiglijke waarneming ("sensing). Bij het nemen van beslissingen wordt uitgegaan van de onpersoonlijke analyse ("thinking"): een logisch proces van redeneren waarbij stap voor stap van veronderstellingen naar conclusies wordt gegaan. Briggs-Myers \& McCaulley [1990] omschrijven de persoonlijkheidskenmerken van het ST-type als het op een praktische manier witwoeren van een onpersoonilye analyse op waargenomen feiten gebruikmakend van technische vaardigheden ${ }^{43}$.

Bij het formuleren van de derde onderzoeksvraag is verondersteld dat de accountant steeds vaker gevraagd wordt een oordeel te geven over bedrijfsprocessen. In bijlage 25: "MBTI indicatoren van 143 accountants en 89 consultants volgens CAPT" zijn daarom ter vergelijking de gegevens weergegeven van 89 consultants die gespecialiseerd zijn in management analyses [Briggs-Myers en McCaulley, 1990]. Hieruit is een verschil warneembaar tussen de karakteristieke voorkeuren van accountants en consultants. Consultants blijken een grotere voorkeur te hebben voor werk dat aandacht vragt voor het oplossen van nieuwe problemen, als gevolg van de "intuition" indicator ( $N$ ), en warbij service verleend wordt aan mensen binnen een hamonieuze en warderingsvolle omgeving, als gevolg van de "feeling" indicator $(F)^{44}$.

\subsubsection{Resultaten overige studies met de Myers-Briggs Type Indicator samengevat}

Volgens Wheeler [2001] $]^{45}$ zijn - sinds de publicatie in 1962 - tot en met 1998 circa 4000 wetenschappelijke studies verschenen waarin de Myers-Briggs Type Indicator is gebruikt. In de periode 1985 tot en met 1996 bedroeg het aantal wetenschappelijke artikelen zelfs gemiddeld 200 per jaar ${ }^{46}$. Gelet op deze aantallen vindt Wheeler 
[2001] het aantal onderzoeken waarin binnen het accountancygebied op de een of andere wijze gerefereerd wordt aan de MBTI, verrassend klein, te weten zestien sinds 1980 . Hieronder wordt kort ingegaan op de uitkomsten van vijf onderzoeken waarin het vaststellen van het MBTI type van de accountant voorop stond.

Het wetenschappelijk onderzoek door Jacoby [1980] laat zien dat accountants een duidelijke voorkeur hebben voor de cognitieve stijlcategorieën ISTJ en ESTJ. In de onderzoeksgroep waren 333 accountants uit de grote accountantsmaatschappen betrokken: 186 werkend in de auditpraktijk, 38 in de belastingpraktijk en 109 in de adviespraktijk.

Schloemer en Schloemer [1997] hebben een studie gedaan naar eventuele veranderingen in de verdeling over de verschillende cognitieve stijlcategorieën, als gevolg van de zich veranderende controlemethodologieën bimnen de grote accountantsmaatschappen. Zij vonden evenwel geen verschuiving in de verdeling. Een duidelijke voorkeur van accountants voor de cognitieve stijlcategorieën ISTJ en ESTJ werd geconstateerd. Zij onderzochten 125 accountants uit de grote accountantsmaatschappen: 59 werkend in de auditpraktijk, 45 in de belastingpraktijk en 21 in de adviespraktijk. In de studie van Schloemer en Schloemer [1997] worden ook twee oudere onderzoeken aangehaald, te weten van Otte uit 1984 en van Kreiser, McKeon en Post uit 1990. Otte onderzocht 494 accountants van relatief kleine accountantskantoren, betrokken in zowel de auditpraktijk als in de belastingpraktijk en de adviespraktijk. Kreiser, McKeon en Post onderzochten 86 accountants, zonder de functionele gebieden te onderscheiden waarin deze accountants werkzaam waren.

De gegevens uit deze onderzoeken, angevuld met de gegevens uit het onderzoek van Briggs-Myers en McCaulley uit 1990, zijn opgenomen in bijlage 26: "MBTI uitkomsten van 1181 accountants volgens diverse onderzoeken'47. Van alle onderzoeken bij elkaar (de gegevens van 1181 accountants) zijn de gemiddelden verwerkt. Een aantal voorkeuren komt duidelijk naar voren:

- binnen de waarnemingsindex heeft de indicator 'sensing' met $61 \%$ de voorkeur;

- binnen de oordeelsvormingindex heeft de indicator 'thinking' met $75 \%$ de voorkeur;

- binnen de attitude-index heeft geen van de twee indicatoren een sterke voorkeur;

- binnen de voorkeursindex heeft de indicator 'judging' met $72 \%$ de voorkeur.

Hieruit kan de conclusie worden getrokken dat in die MBTI-types waar de drie uit-gesproken voorkeuren samenkomen, het STJ-type, de meeste accountants zijn gerepresenteerd. Dit blijkt het geval bij de ISTJ-en ESTJ-types, die samen $39 \%$ van de 1181 accountants vertegenwoordigen. 


\subsection{Samenvatting}

In het worenstaande is het generieke model van Libby [1995] toege]icht. Dit model is gebaseerd op beslissingstheorieën en de wijze waarop door mensen informatie wordt verwerkt. Om het model beheersbaar te houden heeft Libby [1995] motivatie voor alle accountants als een constante beschouwd en zijn omgevingsfactoren alleen dan in beschouwing genomen als het onderzoek dit vereist. Het model wordt weergegeven door twee functies waarbinnen vier variabelen worden onderkend, te weten:

$$
\begin{aligned}
& \text { Kwaliteit accountantsoordeel }=f \text { Aanleg, Kennis\} } \\
& \text { Kennis }=f \text { Aanleg, Ervaring }\}
\end{aligned}
$$

Bij de input variabele 'Ervaring' wordt onderscheid gemaakt tussen direct en indirect gerelateerde ondervindingen. Onder de direct gerelateerde ondervindingen wordt verstaan: de kennis die accountants opdoen in de tijd dat zij werkzaam zijn bij een accountantsorganisatie in opdrachtrelaties. Ervaren accountants blijken meer kemnis te bezitten en een beter gestructureerd kennisbeeld te hebben dan beginnende accountants, en gebruiken daarbij verschillende beslissingsprocessen [Bédard, 1989]. Daarnaast blijkt dat 'training on the job' een veel grotere bijdrage levert aan het kennisbeeld van de accountant dan werkinstructies in de vorm van checklisten [Bonner en Walker, 1994]. Onder de indirect gerelateerde ondervindingen wordt verstaan: de kennis die accountants opdoen via hun 'school'-opleiding, permanente educatieve programma's en instructies van de directe collega's [Bonner en Pennington, $1991]$.

De input variabele 'Aanleg' wordt gezien als een 'internal state of mind' [Libby, 1995]. Aanleg is deels aangeboren en deels gevornd door instructie en ervaringen en is context-bepald. Hierdoor is niet iedere aanleg aan elkaar gelijk. De noodzaak voor een bepaald soort aanleg is afhankelijk van de taak die de accountant opgedragen krijgt [Libby, 1995]. Onder aanleg wordt verstaan het totaal van het herkennen van causale verbanden, interpreteren van gegevens en het bezitten van een analytisch redeneervermogen. Dit geheel wordt ook wel probleemoplossend vermogen genoemd [Bonner en Lewis, 1990]. Gelet op de overeenkomst van het proces van 'oplossen van problemen' met het proces van 'nemen van besluiten' is een benadering van de variabele 'Aanleg' vanuit het besluitvormingsproces mogelijk. Hierdoor gaan de mogelijkheden van meting van cognitieve stijl en tolerantie voor ambiguitteit eveneens tot het meetinstrumentarium behoren.

De 'intermediate'-output variabele 'Kennis' wordt evenals de variabele 'Aanleg' gezien als een 'internal state of mind' waardoor het niet mogelijk geacht wordt de 
variabele 'Kennis' rechtstreeks te observeren [Libby, 1995]. Kennis is daardoor geen eenvoudig begrip. Een aantal mogelijke indelingen van Kennis is met elkar in relatie gebracht op basis waarvan tot een overall indeling gekomen is. Het effect dat de 'intermediate'-output variabele 'Kennis' heeft op de output variabele 'Kwaliteit accountantsoordeel', kan alleen worden bepaald door na te gaan in hoeverre kennis en aanleg van de accountant passen op de specifieke taak die hem is opgedragen en de prestaties op die taak [Libby, 1995]. Tevens is stilgestaan bij de opbouw van de prototypische mentale modellen.

De output variabele 'Kwaliteit accountantsoordeel' wordt omschreven als het oordeelsvormingproces van mensen die ervaring hebben op een bepaald gebied en hun oordeelsvormingproces aanwenden als onderdeel van hun werk [Gibbins, 1984]. De uiteindelijk verkregen oordelen vereisen een prototypisch mentaal model waartegen de werkelijkheid gespiegeld wordt [Frederick en Libby, 1986]. De accountant leunt zwaar op deze prototypische mentale modellen die taak gericht zijn [Lewis, Shields en Young, 1983; Lewis, 1980; Ashton, 1974a, 1974b].

Vervolgens is ingegaan op het begrip professional judgment. Na een uiteenzetting van de evaluatiecriteria bij het bepalen van professional judgment en de betekenis van de prototypische mentale modellen bezien vanuit de accountantsprofessie wordt een conclusie getrokken op welke wijze het professional judgment benaderd kan worden. Aangezien de prototypische mentale modellen en de wijze waarop deze worden gehanteerd niet rechtstreeks waarneembaar zijn, kan 'consensus' gezien worden als een proxy voor professional judgment vanuit het gezichtspunt van de accountantsprofessie.

Aan het einde van dit hoofdstuk is ingegaan op de gehanteerde psychologische tests. Tevens zijn de resultaten van een aantal onderzoeken naar cognitieve stijl samengevat. In deze samenvatting zijn onderzoeken opgenomen die gebruik hebben gemaakt van de Myers-Briggs Type Indicator. Deze Indicator is gebaseerd op de theorie van Jung. Sinds de publicatie van de Myers-Briggs Type Indicator in 1962 is deze Indicator in naar schatting 4000 wetenschappelijke publicaties gebruikt; sinds 1980 slechts 16 keer op het gebied van accountancy [Wheeler, 2001]

Vorenstaande theoretische beschouwingen dienen als onderbouwing voor de in hoofdstuk 3 gemaakte keuzes ten aanzien van de te verzamelen gegevens alsmede voor de hypotheses die ontwikkeld worden om antwoord te kunnen geven op de in hoofdstuk 1 geformuleerde onderzoekswragen. 


\section{Noten}

1 Zonder uitputend te zin "zijn te nomen op het intermationale whak de onderzoelen en publicates van onder meer Haste [2001], Krechal [2001], Choo en Curtis [2000], Davis, Kennedy en Maines [2000], Hunton, Wier en Stone [20001, Mascha en Miller [2000], Bonner [1999], Mock en Turner [1999], Shelton [1999], Tan en Kao [1999], Ashron en Ashon [1995], Libby [1995], Solomon [1995], Solomon en Shields [1995], Baggs, Bujink, Majoor, Mock, Quadackers en Schilder [1994], Libby en Luft [1993], Bonner en Pennington [1991], Bailley [1990], Bedard [1989], Choo [1989], Colbert [1989], Jolnnson, Janal en Berryman [1989], Libby, Artman en Willinglam [1985], Troman en Yeron [1985], Scote [1984]. Biggen Mock [1983] Felix en Kinney [1982], Libby en Lewis [1977]. Bhnen de Nederlandse professie zijn eveneen in de afgelopen jaren dit soort onderzoeken uitgewoerd en gepublicered zoals Van Eijkelenbung [2001], Van Kujjck [1999], Brugman, van Roosmalen wen Weisfelt [1997], Vaatstra [1996], Vaassen [1993], Van de Poel en Vaasen [1988].

2 Letwerijh zegt Libby: task-related enioumers that prowide opportwnines for leawing' [Libby, 1995, table 1].

3 Dedand en Chi [1993] verwijzen in thun artikel naar een artikej van Frensch en Siternberg 'Expentice and intelligent Whinking: When is it worse to know better' gepubliceerd in Advances in the Psychology of Himan Intelligence", 1989 .

4 Bedatd [1989] getft als voonbeeld dat indicn iemand 25 glazen bier per dag drink hij zeer zeker en envaren drinker is; maan fuet majkt hem niet noodzakeljk tot een expert op het gebied wan bier.

5 De twee soorten zijn:

- Sitnational expertence: the duration of total audit experience:

- Organizitional experience the duration of a subordinate sexperience with a staffgroup and its superior Mejxnet an Wellher, 1988].

6 Zonder en limitatieve opsomming na te streven wordt verwezen naar Lloyd en Goldschmidt [2003], Roberts en Dillard-Eggers [2003], Peecher en Solomon [2001], Van Kuijck [2000], Bindenga [2000], Tamboer [2000], Lihby [1995], Bédird [1994], Frederick, Heiman-Hofliman en Libby [1994], Bédard en Chi [1993], Vaassen [1993], Lbby en Lipe [1992], Tubbs [1992], Ashton [1991], Bonner [1991], Bonmer en Pennington [1991], Brown en Solomon [1991], Choo en Trotman [1991], Frederick [1991], Bonner en Lewis [1990], Libbyen Frew derick [1990], Marchant [1990], Bédard [1989], Choo [1989], Colbert [1989], Davis en Solomon [1989]. Johnson, Jamal en Berryman [1989], Meixner en Welker [1988], Bamber [1983], Hamilton en Wright [1982], Bragman, Roosnalen en Weisfelt [1997].

7 Ingesteld door de beroepsorganisatie als eis voor inschrijving in het register

8 Letterlijk zegt Libby: 'capaciy to complete information-processing rakles that contribute to audit problem solning' [Libby 1995, table 11

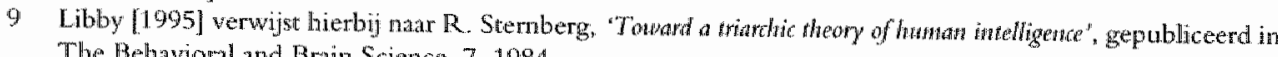
The Behavioral and Brain Science, 7, 1984

10 Probleemoplossend vermogen is de vertaling van de rem 'problem-solving ability'.

11 Besilutwataligheid is de vertaling van de term 'decision-making ability'.

12 Door Zebda [1989] worden onderzoken genoemd wan onder meer Einom en Hogath [1985], Kahneman an Twerky [1979], Frave [1978], March [1978, 1976], March en Olsen [1976], Sherman [1974], Ellsberg [1961],
Savage [1954].

13 Libby [1995] noent onderzoeker wan Abdohnohanumadi $[1991]$, Choo en Trotman [1991], Wright. Ho en Davis [1991], Moeckel [1990], Biggs, Mock en Watkins [1987]. Wright [1987], Bouwman [1984], Messier
[1983].

1. Door Libby [1995] wonden onderzoekn genoend wan Abdolnohammadi [1991], Choo en Trotman [1991]. Wright, Ho en Davis [1991], Moekel [1990], Biggs, Mock en Wakins [1987], Wright [1987], Bouwman
[1984, Mesier [1983].

15 Letterlijk age Libby: "ingomation stored in memory" [Libby, 1995, tab]e 1].

16 Fen vergelijking kan hier getrokken worden met Newrale Netwerken. Binnen Neurale Netwerken zijn in de meest enwoudige vom een tweetal lagen met neuronem aanwezig, de input-layer en de output-layer [Cruz, 19911. Hierme worden constructies gegenereerd die meestal de vorm hebben van "if..... else". Zodra deze mest eenvoudige vom wordt vetlaten worden tussen deze twee layers zogenaande hidden layers gelegd die bepalend zijn voor de afhandeling van de inputvariabelen mar de output variabelen. In deze hidden-layers is de gecompliceerdate kennis ondergebracht. De complexiteit van de kennis kent een positieve correlatie met het atanthidden-layets dat wordt gehanterd. Deze hidden-layers zin zeer bepalend voor de output variabelen. Her kumen begrijpen van dergelijke hidden-layers is alleen mogelijk uitgande van diepgande kennis var de 


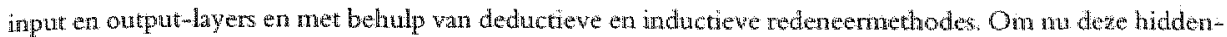
layers te kunnen testen wordt wak gebruik gemaakt wan de zogenande Turing-test. Hierbij worden de testgevallen aangedragen do or waktechnisch inhoudelike experts en verwolgens at random verwerkt door hat $N$ ewrale Netwerk dan wel door een menselifke expert. De wragenstellers weten niet door wie of wat hun vrag beantwoord wordt. Nadat de wagensteller het antwoord heeft terugontvangen geeft hij an of het Neural Natwerk dan wel de mernselijke expert het antwoord heeft gegeven. Het Neurale Nelwerk wordt als gevalideerd beschouwd indien de vragensteller met een voorat bepalde frequentie, niet kan vastitellen door wie of door wat de beoordeling heeft platsgevonden.

17 Bêdard en Chi [1993] refereren hier aan studies van Choo en Troman [1991], Frederick [1991], Renne [199]]. Klersey [1990]. Libby en Frederick [1990] en Weber [1980].

18 Bédard [1994] verwist hierbij naar een artikel van ].R., Anderson "The Arditemure of Cognithon", Cambridge, Harvard University Press, 1983 terwijl Bonner en Walker [1994] verwjzen naar een artikel van J.R, Andenon 'Aciusition of cognifine skill. Psychological Review 89 (July).

19 Een op inductief redeneren gebaseerd proces creèt zijn tithomst op basis van interpreteren en generalisenen van gegevens.

20 Letterlijk zegt Libby: 'comespondence of the judgnent tha a criterion" [llibby, 1995, table 1].

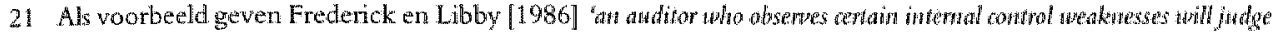

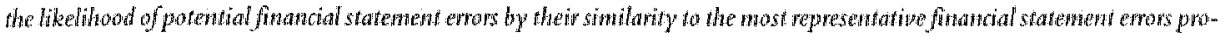
duch by those circumstances'. Dit is een voorbeeld van een contingentie-benadering.

22 Frederick en Libby [1986] stellen dat 'ff the mental model differs between the expert and the nowice, the applying the

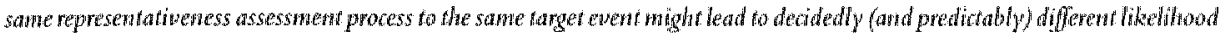
assessments".

23 Een redenering wordt indwetief genoemd wanneer uit premissen (veronderstellingen) over enkelle zaken van een bepald soort en conclusie word getrokken ower enkele of alle overige zaken van die soort Llacey, 1989, pp 138-141]. De gegeneraliseerde uitspraken kumnen op andere c.q. meer gegeven betrekking hebben dan op de wargenomen gegewens. Zo kumnen op basis wan een deel watneming uitspraken worden gedaan welke als geldend woor de gehele populatie worden bestempeld. De relatieve omvang van de deelwarneming, zijnde het aantal waarnemingen ten opzichte van het totale probleendomein, is dan éen van de factoren, bepalend voor do juistheid van de gegeneraliseerde uispraken. Een andere wijze van redeneren is de deductieve redeneermethode. Een redenering wordt deductief genoemd waneer de conclusie op zadanige wijze uit de premissen (veronderstellingen) wordt getrokken dat het ontkennen van de conclusie het on tkennen van de premissen inhoudt [Lacey, 1989, pp 66]. Een op deductief tredeneren gebaseende gegevensanalysetectniek creëert informatia door het combineren wan gegevens uit de gegevenswerzameling.

Holsheimer en Siebes [1994] benadrukken dat het meest belangrijke verschil tussen inductief en deductief redeneren het werschil in zekerheid is over het waarheidsgehal te van de tesultaten. De resultaten behald met een technek gebaseerd op inductief redeneren zijn een interpretatie van de gegevens wit de gegevenswerzaneling. Deze interpretatie behoeft net noodzakelijkerwijs walide te zijn in de werkelijkheid

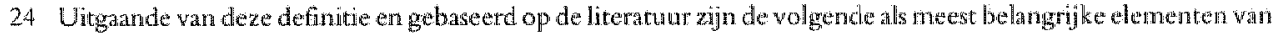
profesional judgment te noemen warbij en onderyerdeling is angehonder van persoonlijk aspecten, voorschriften en richtijnen alsmede ethische vereisten. Bij het samenstellen van deze kermerken is gebruik gemakt van elenenten zoals beschreven in onder meer publicaties van Libby [1995], Brugrnan en Weaffelt [1993], Bédard [1991a], Bédard en Biggs [1991], Choo en "I"rotman [1991]. Bonner en Lewis [1990], Büdard [1989], Johnson, Jamal en Berryman [1989], Burt [1988], Gibbins en Mason [1988], Froderick en Libby [1986], NIVRA [1986] en Ashton [1974a, 1974b].

Peroonlijke aspecten:

- het hebben van ean significante ervaring en domeingebonden kennis;

- het hebben van een praktisch gewoel verkregen door ervaning, de zogenaamde 'recall',

- het kunnen kiezen tussen elkar niet uirsluitende alternatiewen, de zogenamde anbiguiteitgevoeligheid:

- het kunnen werken met modellen en concepten;

- het kumnen incerpreteren van patronen, de zogenaande patoonharkenning;

- het kunnen inschatten wan gevolgen;

- het kunnen integreren van verschillende detoordelen in éen eindoordeel;

- het consistent zijn in de uitkonst van zijn onderzoek gedurende en afzienbare periodes

- het zich persoonlijk verantwoordelijk woelen voor de al dan niet voorziene gevolgen; 


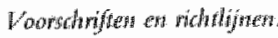

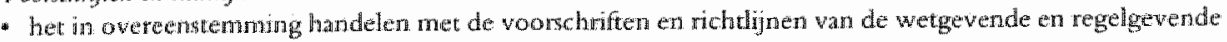
instancies;

- het is overeenstemming handelen met de algemeen greldende opwatingen binnen de professie;

- het vakechniscly verdedigbatar en valideerbar zijn wan de gegeven oordalen:

- het bijagen an een verdere onitwikkeling van de professic;

- het zich onthouden van her actiwiteicen welke schadelijk kunnen zijn voor de professie;

- het in stand holaden wan en adequate opleiding;

Ethisclio wereaten:

- het in wwerenstemming handelen met de geldende maarschappelike opwattingen in hat algemeen;

- het onafharke lijk, betrouwbar en integer zijn;

- het in bepaalde mate consistent zijn in $2 \mathrm{jn}$ oordelen met vergelijkbare onderzoeken nitgevoerd door wewchillende leden wan de professie al dam niet binmen een wergelijkbare context;

- het mattschappelijk verdedigbaar en valideerbaar zijn van de gegeven oordelen.

25 Verwezen word nat (overzichtsw) artikelen van onder meer Tamboer [2000], Bindenga [2000], Solomon en Shields [1995], Biedard en Chi [1993], Vassen [1993], Choo [1989] en Colbert 1989].

26 Dorr Sollomon en Shields [1995] worden bij hun categorisate de volgende vijf theoretische onderzoekskaders gehantecerd:

- Policy capturing studies; hierin vallen 28 onderzoeken die vanuit de empirie de oordeelsworning- en beshitvormingsprocessen van de accountants trachten te modelleren.

- Probabilistic judgrnent studies, hierin vallen 12 onderzoeken de hun oorsprong hebben in de gedragswetenschappelijke beslissingstheorie en in het algemeen gericht zijn op warschijnlijkheidsevaluaties.

- Heuristics-and-biases studies; hierin vallen 12 onderzoeken waarin nagegaan is in hoeverre de warschijnlyjkbeidsoordelen wan de accountant beschreven konden worden.

- Cognitive process studies; hierbij wordt werwezen naar het uitputtende overzicht in het artikel van Libby [1995] waaran andacht is gegewen aan het modelleten en testen van cognibeve activiceiten wanrbij theorieen en methoden worden gehanteerd onteend an de cognitjeve psychologie en de cognitieve wetenschap.

- Multiperson information-processing studies; lhierin vallen 4 onderzoken warin de aardacht werd gericht op de verschillen tassen de groeps- en individuele oordeelsvomingsprocessen.

Binnen deza throre tische onderzoekskaders worden de onderzoeken ingedeeld naar de wolgende zeven fases in her controleproces wan de jarrekening:

- Oriventation;

- Evaluate information-system architecture and process;

- Tactical planning:

- Plan indirect rests of finaricial statenents assertions and evaluate test results:

- Filn direct tests of finaricial statementes assertions and evaluate test results.

- Evaluate angregared recults;

- Choose report.

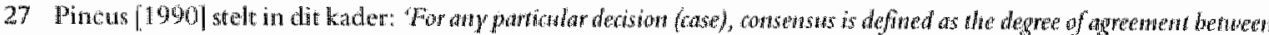

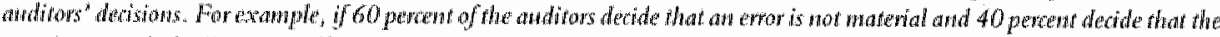

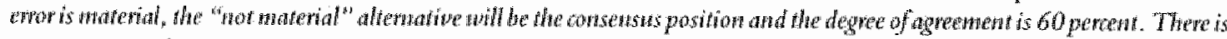

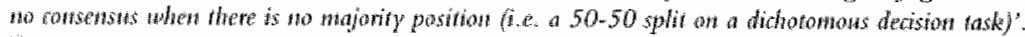

28 Deze stelling is door Van Hulsentop geponeerd tijdens zijn inagurele rede in 1976.

29 Toevoegng in deze studie.

30 Zie voor en nadere beshrijving van de MBTI npes bijlage 9: 'Mycers-Briggs Type Indicator, exin leeswijzer'

31 Zondler een limitntieve opsomming te willen geven zijn te noemen: de Myers-Buggs Type Indicator. de Driver wo Mock decision style test, de Embedded Figures test, de Analytic/Henistic test, de Tolenace for Antbiguity test, de Hopwood leadership style test, de Seler en Bartlet leadership style test, de House leadership style test [Vastsen, 1994].

32 Carl Gustav Jung $(1875-1961)$

33 Als basis is gethanterd: 'A guide to the development and nse of the Myers-Briggs Type Indicator' Briggs-Myers an

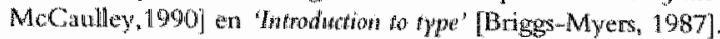

34 Beschrijwingen zijn opgenomen in billage 9: "Myers-Briggs Type Indicator, een leeswijzer". 
35 Het Center for Application of Psychological Type is gevestigd in Ganeswie, Florida. De dataluase watuan de gegevens zijn ontleend is opgebouwd vanaf 1990 en onvat meer dan 250.000 MBTI records.

36 Deze gegevens zijn opgenomen in de appendix D van: "A gude to the Dewelopwent and Use of the Myers-Briges Type Indirator" [Btiggs-Myers en Mic Caulley, 1990].

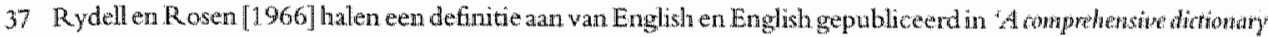

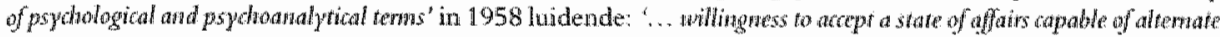

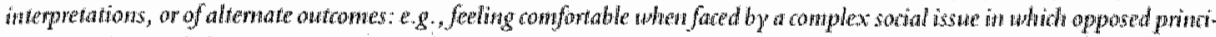

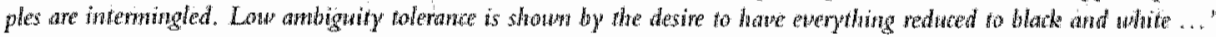

38 Door Zebda [Zebda, 1989] worden onderzoeken genoend wan onder meer Einhorn en Hogarth [1985!, Kahneman en Tversky [1979], Franke [1978], March [1978, 1976], March en Olsen [1976], Sherman [1974], Elisberg [1961] en Savage [1954].

39 Door Varssen [1994] worden onderzoeken genoend van onder meer Pinc us [1990], Gul [1984] en MancDonelli $[1970]$

40 Door Van de Poel [1986] worden onderzoeken genoend wan onder meer Gul [1984], MacDonald [1970] en Rydelli-Rosen [1966].

41 Briggs-Myers \& McCaulley [1990] geven als beschrijuing var de [ST] en EST] types:

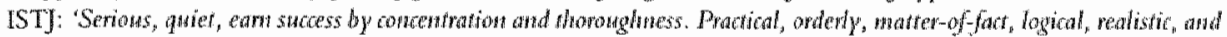

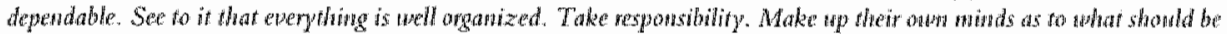

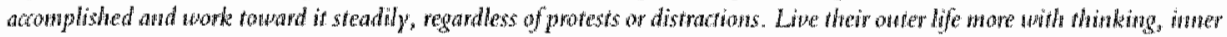
more whit sensing".

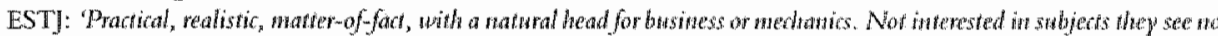

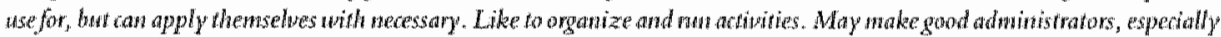

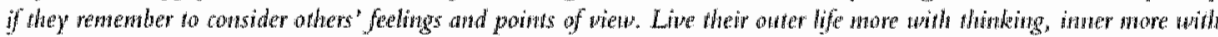
sensing'.

42 Wheeler [2001] wat deze samen met de bewoording:

ISTI: 'Pratical, decisive, logical, sensible, detached".

EST]: 'Practial, decisive, logical, objectively critical, systematic'.

43 In A gude to the development and we of the Myer-Briggs Type Indictor' pagina 33 [Brigg-Myers en MeCaulley, $1990]$ wordt de volgende voorspelling gedaan voor het ST type:

'Type theory predicts that their best chances for success and satisfaction tie in fields that dentand impersand analysis of conchete facts such as economic, law, sugery, business, accouting, production, and he handling of mathites and waterials,"

44 Ten opzichte van de wamemingen gedaan voor accountants verschuift de voorkeur van de consultants in de warnemingsindex van 'sensing" naar "intuition' en in de oordeelsvomingindex wan "Uinking' nar 'feeling". De totale procentuale voorketur van de consultants voor het ST type bedragt 28,08\% tegen 46, $14 \%$ bij de accountants en voor het NF type 33,71\% tegen 13,99\% bij de accountants.

45 Hierbij verwijst Wheeler [2001] nar een opgave gedaan in de publicatie van Myers, McCaulley, Qenk en

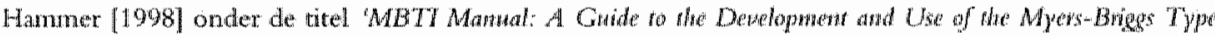
Indiano' als derde edicie gepubliceerd bij Palo Alto, CA: Consulting Pychologists press.

46 Herbij verwijst Wheeler [2001] natar en opgave gedaan in de publicatie van Hammer in 1906 ond ar do titel

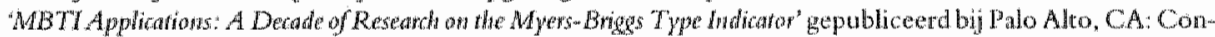
sulting Psychologists Press.

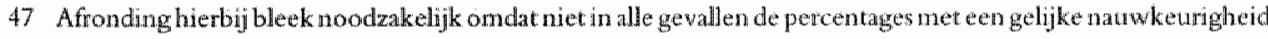
beschikbaar waren.

48 IST] met 23\% en ESTJ met 16\%. Uit ean vergelijkbaar onderzotk onder 162 controllers [Blais 2000] biack de" voorkeur voor ISTy the liggen op $35 \%$. 
7 


\section{Vorming hypotheses en invulling model}

\subsection{Inleiding}

In het eerste deel van dit hoofdstuk worden de hypotheses geformuleerd, in het tweede deel worden de data besproken. De vorming van de hypotheses is gebaseerd op de onderzoeksvragen zoals die zijn weergegeven in hoofdstuk 1. Bij het maken van de keuzes van de gegevens is het model van Libby [1995] zoals beschreven in hoofdstuk 2 gevolgd. Aangezien het onderzoek zich met name richt op de accountantsprofessie in Nederland is hiermee, indien noodzakelijk, bij de keuze van de gegevens rekening gehouden.

In hoofdstuk 4 is de onderzoeksopzet beschreven. Ook is daar weergegeven in hoeverre daadwerkelijk de gevraagde onderzoeksgegevens van de bij het onderzoek betrokken accountants zijn ontvangen en zijn gebruikt in de analyses. In hoofdstuk 4 wordt ook beschreven hoe het onderzoek in opzet aansluit bij de in het eerste deel van dit hoofdstuk ontwikkelde hypotheses.

\subsection{Hypothesevorming}

De vorming van een aantal hypotheses vindt plaats om de in hoofdstuk 1 gestelde onderzoeksvragen te beantwoorden. Die onderzoeksvragen zijn gericht op het vaststellen van:

1. de 'consevsus' tussen de oordelen van de accountants; als een proxy voor professional judgment;

2. de 'voorkeur" van de accountant; als een proxy voor het soort beheersingsmaatregel dat de grootste bijdrage levert aan het prototypisch mentaal model gericht op de beoordeling van administratief-organisatorische processen; 
3. de teranderingen van het psychologische profiel van de acountant.

In het vervolg van deze paragraaf zijn de te vomen hypotheses per onderzoeksvraag gegroepeerd. Bij het formuleren van de hypotheses is uitgegaan van de theoretische beschouwingen in hoofdstuk 2 en de ontwikkelingen in het vakgebied Administratieve Organisatie zoals beschreven in hoofdstuk 1. Tevens zijn de hypotheses gericht op de accountantsprofessie zoals die zich heeft ontwikkeld binnen de Nederlandse context.

\subsubsection{Consensus tussen oordelen van accountants}

De eerste onderzoeksvraag in hoofdstuk 1 gaat over het evaluatiecriterium 'consensus' volgens het in hoofdstuk 2 opgenomen framework voor het bepalen van professional judgment van Solomon en Shields [1995] en dat van Ashton [1983]. De vraag luidt:

V1: Komen accomnants bij de beordeling wan gelijke administratief-organisatorische processen tot gelikluidende oordelen?

Zoals in hoofdstuk 2 is aangegeven wordt consensus in de gegeven oordelen gezien als een proxy yoor professional judgment. Professional judgment is niet rechtstreeks waarneembaar; het is het geheel van prototypische mentale modellen en de wijze waarop deze worden gehanteerd. Professional judgment is dan de basis warop de output variabele 'Kwaliteit accountantsoordeel' binnen de context van het model van Libby [1995] is gestoeld [Gibbins, 1984]. Gibbins verstaat onder professional judgment het oordeelsvormingproces van mensen die ervaring hebben op een bepaald gebied en die hun oordeelsvorming aanwenden als onderdeel van hun werk. Dat aanwenden van ervaring vindt plaats bij het vormen van het oordeelsvormingproces, resulterend in het accountantsoordeel.

De wijze waarop de kwaliteit van het accountantsoordeel gemeten moet worden, vereist een duidelijke normstelling [Libby, 1995]. Dit onderzoek richt zich op oordelen gegeven door accountants aangaande het kennisdomein Administratieve Organisatie. In paragraaf 1.2 is het belang van Administratieve Organisatie beschreven. Hieruit blijkt dat de beoordeling van administratief-organisatorische processen een centrale plaats inneemt, zowel bij de beoordeling van de jaarrekening als bij de beoordeling van de beheersing van de organisatie als onderdeel van de zogenaamde comporate governance-discussic. Op dit kennisdomein moet de nommstelling dan ook betrekking hebben. Zoals is aangegeven door Schilder [1994], Bonner [1990], Keasey en Watson [1989], Meservy, Bailey en Johnson, [1986], Mayper [1982] en bevestigd door Mouthaan [2001, 2000], bestaat evenwel geen eenduidige normstelling voor het kennisdomein Administratieve Organisatie. De toetsingsnorm moet 
worden ontleend aan het totaal van de ontvangen antwoorden van de leden van de accountantsprofessie en dus aan de consensus daarvan.

Overeenkomstig de uitkomsten van onderzoeken uitgevoerd door onder meer Gaumnitz, Nunamaker, Surdick en Thomas [1982] en Hamilton en Wright [1982] mag een hoge mate van consensus worden verwacht tussen de accountants bij de beoordeling van administratief-organisatorische processen en met name in situaties waarbij dezelfde situatie beoordeeld wordt. De eerste hypothese, gericht op de 'Professional Judgment' en benaderd vanuit de proxy 'consensus', kan als volgt worden geformuleerd:

H1: Tussen de oordelen van accountants aangaande de toereikendheid van administratieforganisatorische processen bestaat consensus.

Mede op grond van de in hoofdstuk 1 geschetste maatschappelijke ontwikkelingen zijn de accountantskantoren in continuïteit bezig hun controlemethodologieèn op die ontwikkelingen af te stemmen [Gortemaker, Bindenga, Ten Wolde, Van Kollenburg, Wieleman, Krom, Dassen, Coster en Van Sluis, 1998]. Al langere tijd zien accountantskantoren de uitkomsten van de beoordeling van de getroffen interne beheersingsmaatregelen binnen de administratief-organisatorische processen als richtingbepalend voor hun controlemethodologie [Meservy, Bailey en Johnson, 1986]. De Richtlijnen voor de Accountantscontrole [NIVRA, 2003] schrijven de beoordeling van de administratieve organisatie en interne beheersing zelfs voor als basis voor de risicoanalyse $\mathrm{e}^{1}$. In hoofdstuk 1 is dan ook geconcludeerd dat de basis van de risicobenadering bij de controle van de jaarrekening het oordeel is over de toereikendheid van de administratieve organisatie en de daarin opgesloten interne beheersingsmaatregelen. Geconcludeerd kan dan ook worden dat binnen de accountantskantoren aandacht is voor de beoordeling van administratief-organisatorische processen.

In de voorafgaande theoretische beschouwingen voor de input variabele 'Ervaring' is het belang van de feedback, die accountants krijgen op de door hen uitgevoerde werkzaamheden, voor het leerproces van de accountant benadrukt [Bonner en Wal-ker, 1994; Bonner en Pennington, 1991; Davis en Solomon, 1989; Bédard, 1989]. Enerzijds worden de accountantskantoren als organisatie geconfronteerd met een door het NIVRA ingesteld kwaliteitsreview welke wordt uitgevoerd door collega accountants van andere accountantskantoren. Anderzijds worden de individuele accountants door collega's binnen het eigen accountantskantoor periodiek en vooral 'on the job' op hun prestaties en functioneren beoordeeld. De feedback is zodoende binnen de accountantsprofessie aanwezig [Bonner en Pennington, 1991]. Verder hebben diverse onderzoekers geconstateerd dat naarmate de accountant langer 
werkzaam is binnen de accountantsprofessie en meer ervaring verkrijgt, zijn kennis groeit en die kennis beter in zijn geheugen wordt georganiseerd [Bédard, 1994; Bédlard en Graham, 1994; Bonner en Pennington, 1991].

De tweede hypothese is gebaseerd op de genoemde aandacht binnen de accountantskantoren voor de beoordeling van de administratief-organisatorische processen als richtingbepalend element binnen hun controlennethodologieën en de beter gestructureerde kennis van een accountant die langer werkzaam is binnen de accountantsprofessie. Deze tweede hypothese is gericht op de relatie tussen de inputvariabele 'Ervaring' en 'Professional Judgment', met als proxy 'consensus', en wordt als volgt geformuleerd:

H2: Een toename van het aantal jaren werkervaring in het vakgebied accountancy heeft een positieve invloed op de consensus tussen de oordelen van de accountants.

In hoofdstuk 1 is het begrip administratieve organisatie omschreven als het gehele complex van organisatorische maatregelen en maatregelen van interne beheersing dat direct of indirect betrekking heeft op de goede werking van de bestuurlijke informatieverzorging [Beek en Vaassen, 1999; Starreveld, De Mare en Joëls, 1997; Swigchem, 1987]. Het doel van de interne beheersingsmaatregelen wordt daarbij onschreven als het tijdig opsporen en corrigeren van onvolkomenheden in de uitoefening van bedrijfsactiviteiten. De verschijningsvorm van het systeem van administratieve organisatie is, door het grote netwerk waarin interne beheersingsmaatregelen kunnen samenwerken, situationeel bepaald en kent geen eenduidige normstelling hetgeen de beoordeling van de toereikendheid ervan zeer bemoeilijkt [Mouthaan, 2001, 2000; Bonner, 1990; Johnson, Jama] en Berryman, 1989; Meservy, Bailey en Johnson, 1986]. In de opleiding tot accountant wordt binnen de kernvakken Administratieve Organisatie en Leer van de Accountantscontrole veelvuldig aandacht gegeven aan de mogelijkheden van verschillende mixen van interne beheersingsmaatregelen. Doordat de mixen situationeel bepaald zijn wordt over de toereikendheid van deze mixen in deze kernvakken geen uitspraken gedaan. Wel wordt in de kernvakken aangegeven dat slechts door het beoordelen van de gehele mix van interne beheersingsmaatregelen een uitsprak kan worden gedaan omtrent de toereikendheid van het geheel van interne beheersing.

Interne beheersingsmaatregelen zijn gericht op verschillende aandachtsgebieden en zijn zodoende onder te brengen in vijfsoorten beheersingsmaatregele ${ }^{2}$, te weten:

- Procesbeheersing;

Beheersingsmaatregelengericht op de goede werking van het proces zelf, zoals het 
uitvoeren van allerlei controles, zowel geautomatiseerd als handmatig, inclusief de afwikkeling wan de controleverslagen;

- Financiële beheersing;

Beheersingsmaatregelen gericht op de beheersing van de financiële component van de processen, zoals budgettering;

- Organisatorische beheersing;

Beheersingsmaatregelen noodzakelijk om een proces op een integere en betrouwbare wijze te laten werken, zoals functiescheiding en logische en fysieke toegangsbeveiliging. Deze beheersing ligt derhalve buiten de processen en maakt onderdeel uit van de omgeving waarbinnen het proces werkt;

- Informatiebeheersing;

Beheersingsmaatregelen bedoeld om de betrouwbaarheid van de informatie in continuilteit te kunnen vaststellen c.q. beheersen. Te denken valt hierbij aan het bijhouden van standenregisters en het aanmaken van allerlei verschillenlijsten die aan de directie worden gerapporteerd;

- Prestatiebeheersing;

Beheersingsmaatregelen gericht op de prestatie component van de werknemers in de organisatie, zoals productieregistraties en registraties van ziekteverzuim en verlof.

In paragraaf 1.3 is aangegeven dat de accountant een prototypisch mentaal model opbouwt en dit model hanteert als zijn referentiekader waartegen hij de werkelijkheid afzet [Frederick en Libby, 1986]. In het prototypisch mentaal model gericht op de beoordeling van administratief-organisatorische processen hebben de verschillende soorten beheersingsmaatregelen bij de verschillende accountants niet altijd hetzelfde gewicht. Dit wordt veroorzaakt door het feit dat niet alle accountants op eenzelfde wijze kennis opdoen over de verschillende soorten beheersingsmaatregelen op grond waarvan zij hun prototypische mentaal model aanpassen [Bédard en Chi, 1993]. In paragraaf 2.3.1. is bij de beschrijving van de input variabele 'Ervaring' uitgebreid stilgestaan bij de verschillende soorten instructie die de accountant ontvangt zowel in formele als informele zin. In de opleiding tot accountant, de formele instructie, wordt stilgestaan bij de verschillende soorten interne beheersingsmaatregelen en de verschillende mixen van soorten interne beheersingsmatregelen die bepalend zijn voor de toereikendheid van de interne beheersing ais geheel. De centrale plaats die het vak Administratieve Organisatie inneemt in de accountantsopleiding, zoals weergegeven in paragraf 1.2.2., maakt dat de invloed die hiervan uitgaat naar het prototypisch mentaal model van de accountant gelijkgericht zal zijn. Met betrekking tot de andere onderdelen van formele en informele instructie die de accountant ontvangt is het anders gesteld. Hierbij valt te denken aan kantoorinstructies, adviezen en suggesties van directe collega's tijdens de uitvoering van opdrach- 
ten, permanente educatie programma"s, vaktechnische literatuur [Bonner en Walker, 1994; Bomer en Pennington, 1991]. De invloed van deze instructies alsmede van de training-on-the-job welke uitgaat van de cliëntenportefeuille welke door de accountant wordt bediend zijn veel minder gelijkgericht. Ofschoon steeds opnieuw de verschillende soorten interne beheersingsmatregelen aan de orde komen zal dit niet altijd met eenzelfde frequentie platsvinden. Zoals in paragraaf 2.3.2. is aangegeven vloeit het leertempo, en daamede het opbouwen van het prototypisch mentaal nodel, van een individu voort uit de wijze waarop hij/zij in staat is een beheersstructuur voor zijn kennis op te zetten en te onderhouden alsmede het onderkennen van het 'doelathankelijkheid'-aspect [Libby, 1995; Newell, 1994; Minsky, 1986]. Het vaker geconfronteerd worden met een bepaald soort beheersingsmaatregel zal tot gevolg hebben dat dat soort beheersingsmaatregel een zwaarder gewicht zal krijgen in het prototypisch mental model [Rosch, 1978].

Op grond van de aandacht tijdens de formele en informele instructies die de accountant heeft ontwangen voor de vijf soorten interne beheersingsmaatregelen en de opbouw van prototypische mentale modellen waartegen de werkelijkheid wordt afgezet, heeft de derde hypothese betrekking op de relatie tussen de "intermediate"output wariabele 'Kennis' en 'Professional Judgment' met als proxy 'consensus'. De verschijningsvorm van het systeem van administratieve organisatie is, door het grote netwerk warin interne beheersingsmaatregelen kunnen samenwerken, situationeel bepaald en kent geen eenduidige normstelling [Mouthaan, 2001, 2000; Bonner, 1990; Johnson, Jamal en Berryman, 1989; Meservy, Bailey en Johnson, 1986]. In de opleiding tot accountant wordt veelvuldig aandacht gegeven aan de mogelijkheden van verschillende mixen van interne beheersingsmatregelen zonder over de toereikendheid van deze mixen een uitspraak te doen. Wel wordt aangegeven dat slechts door het beoordelen van de gehele mix van inteme beheersingsmaatregelen een uitspraak kan worden gedan omtrent de toereikendheid van het geheel van interne beheersing.

Deze derde hypothese valt in twee delen uiteen welke als volgt worden geformuleerd:

H3a: Niet het soort beheersingsmatregel maar het aantal verschillende soorten beheersingsmaatregelen dat in een te beoordelen adwinistratief-organisatorisch proces is opgenowen heeft invloed op de consensws tussen de oordelen van de accountants.

Zoals hiervoor is angegeven is de frequentie waarmee een accountant is geconfronteerd met een bepald soort beheersingsmatregel mede bepalend voor het gewicht dat dat soort beheersingsmatregel zal krijgen binnen het prototypisch mentaal model. 
H3b: Een toename van het aantal malen dat een gelijke mix fan soorten inteme beheersingsmaatregelen voorkont in de prakijik van de accountant heeft een positieve invloed op de consensus tussen de oordelen van de accountants.

Zoals hiervoor aangegeven beschikt het management over een groot aantal mogelijke beheersingsmaatregelen, zowel financieel als niet financieel, om haar bedrijfsprocessen en daarin begrepen administratief-organisatorische processen, te beheersen. Eveneens is aangegeven dat door de vele mogelijkheden waarin deze beheersingsmaatregelen onderling kunnen samenwerken, geen eenduidige normstelling bestaat [Meservy, Bailey en Johnson, 1986]. Binnen de opleiding tot accountant wordt veel aandacht aan deze interne beheersingsmaatregelen gegeven. De accountant komt daarnaast bij zijn werkzaamheden steeds opnieuw in aanraking met deze interne beheersingsmaatregelen. Hij zal zich ontwikkelen overeenkomstig het gestelde in de theoretische beschouwing ten aanzien van de variabele 'Kennis', het zogenaamde kennissegment 'episodic procedural knowledge'. Binnen dit kennissegment bouwt de accountant op grond van zijn opleiding, de door hem gehanteerde controlemethologie, ervaring en zijn aanleg zijn prototypisch mentaal model op gericht op het beoordelen van administratief-organisatorische processen. In de theoretische beschouwingen voor de variabele 'Kennis' is aangegeven dat Kennis niet rechtstreeks kan worden geobserveerd; een normstelling ontbreekt. Een te hanteren normstelling kan worden verkregen door het vaststellen van 'consensus', gebruik makend van het prototypisch mentaal model opgebouwd in het kennissegment 'episodic procedural knowledge' van alle individuele bij dit onderzoek betrokken accountants gericht op het kennisdomein Administratieve Organisatie. Zoals hiervoor al uiteen is gezet zullen de verschillende soorten beheersingsmaatregelen vertegenwoordigd in het model niet allemaal hetzelfde gewicht hebben. In de kernvakken Administratieve Organisatie en Leer van de Accountantscontrole wordt steeds benadrukt dat alleen op basis van de beoordeling van de totale mix aan soorten beheersingsmaatregelen een oordeel gegeven kan worden over de interne beheersing als geheel. Geen bepaald soort beheersingsmaatregel wordt meer benadrukt dan een ander. Eventueel kan een bepaald soort interne beheersingsmaatregel bij de beoordeling van administratief-organisatorische processen frequenter voorkomen in de praktijk. Daarnaast kan de aanleg van een accountant van invloed zijn op het toekennen van de gewichten in het model.

De vierde hypothese wordt geformuleerd op grond van de verschillende gewichten die de soorten interne beheersingsmatregelen daarin kunnen hebben. Zoals in paragraaf 1.3. is aangegeven wordt met de term 'voorkeur' dat soort beheersingsmaatregel bedoeld die de grootste bijdrage levert aan het prototypisch mentaal model gericht op de beoordeling van administratief-organisatorische processen. De vierde hypothese is gericht op de 'intermediate'-output variabele 'Kennis' met als represen- 
tatie het prototypisch mentale model van de accountant gericht op de beoordeling van administratief-organisatorische processen en als proxy 'voorkeur', en wordt als volgt geformuleerd:

\section{H4: Acconntants hebben geen voorkeur voor een bepadd soort beheersingsmaatregel.}

Bij de theoretische beschouwing in hoofdstuk 2 over de input variabele 'Aanleg' is aangegeven dat 'Aanleg' moet worden beschouwd als een 'internal state of mind' en datardoor niet rechtstreeks kan worden geobserveerd, maar alleen kan worden afgeleid [Libby, 1995]. Op grond van uitspraken en bevindingen van diverse onderzoekers bestaan mogelijkheden om de invloed van de variabele 'Aanleg' vanuit de cognitieve psychologie te observeren. Daarbij wordt gekeken naar de besluitvaardigheid ${ }^{3}$ in plaats van het probleemoplossend vermogen ${ }^{4}$. Hierbij wordt in paragraaf 2.5 gerefereerd aan cognitieve stijl onderzoeken, meer specifiek met als basis de typologie van Jung, en de analyses van de tolerantie voor ambiguiteit [Vaassen, 1993; Bédard, 1991a, 1991b; Chenhall en Morris, 1991; Davis, Grove en Knowles, 1990; Masuch en LaPotin, 1989; Zebda, 1989]. Uit de theorie van Jung kan afgeleid worden dat verschillen in gedrag te herleiden zijn tot de individuele voorkeur voor het "waarnemen' of het 'oordelen'. 'Waarnemen' omvat het geheel van het zich bewust worden van de omgewingsfactoren. "Oordelen" omvat het gehele proces van het komen tot een conclusie op basis van de waarnemingen. Als mensen niet variëren in hun waamemingen ('waarnemen') en in de wijze waarop zij tot een conclusie komen ('oordelen'), en derhalve behoren tot dezelfde warnemings - en oordeelsvormingindex combinaties, dan zullen zij overeenkomsten vertonen in hun reacties, interesse, waarden, motivatie en kumnen. Hoe groter de groep is met gelijkgezinden hoe duidelijker een goed profiel is vaststellen [Briggs-Myers en McCaulley, 1990; Briggs-Myers, 1987; Rosch, 1978]. Uit bijlage 26: "MBTI uitkomsten van 1181 accountants volgens diverse onderzoeken" en bijlage 27 : "MBTI indicatoren van 199 accountants volgens huidig onderzoek' kunnen de accountants als volgt tot de watamemings-en oordeclsvormingindex combinaties worden gecategoriseerd.

Zoals uit de tabel in figuur 3.1 blijkt zijn de accountants in de waannemings-en oordeelsvormingindex combinaties NT en ST het sterkst vertegenwoordigd.

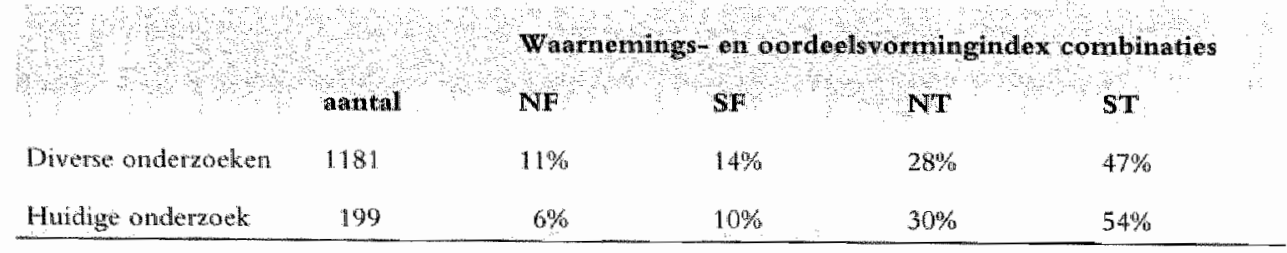

Figutar 3. Verdeling accountants over warnemings- en oordeelswormingindex combinates 
In de theoretische beschouwing over de input variabele 'Aanleg' in hoofdstuk 2 is aangegeven dat van een accountant een zekere mate van "professional scepticism" verwacht mag worden. Dit komt tot uitdrukking in het gevoelig zijn voor en kunnen omgaan met inconsistenties en contradicties in informatie. Dit impliceert een zekere mate van tolerantie voor ambiguiteit [Libby, 1995]. Individuen met een hoge tolerantie voor ambiguiteit hebben geen problemen in situaties die niet strikt in twee delen zijn in te delen; zij kunnen gemakkelijk omgaan met de zogenaamde 'grijze' gebieden. Individuen met een lage tolerantie voor ambiguiteit zien dubbelzinnigheid als bedreigend en kunnen moeilijker omgaan met dubbelzinnige situaties [Wright en Davidson, 2000]. Zij zien de wereld in al zijn facetten het liefst dichotomisch, ofwel zwart wit. "Professional scepticism" is een mentaal proces; de ambiguiteitwaarde (de mate van tolerantie voor ambiguiteit) kan dan ook worden gezien als een proxy voor 'professional scepticism'. Deze ambiguiteitwaarde kan variëren van -20 tot en met +20 en wordt in gehele even getallen uitgedrukt. In dit onderzoek is de reeks verdeeld in een viertal groepen.

Op grond van de indeling van accountants in typen bij de cognitieve stijl onderzoeken, de conclusies van de onderzoeken van Briggs-Myers en McCaulley [1990], Briggs-Myers [1987] en Rosch [1978] en de indeling van accountants op basis van ambiguiteitwaarde kan de vijfde hypothese worden geformuleerd. Deze hypothese is gericht op de relatie tussen de input variabele 'Aanleg' en 'Professional Judgment', met als proxy 'consensus', en luidt:

H5a: Accountants behorende tot de twee MBTI watnemings-en oordeelswormingindex combinaties NT en ST zullen meer consensus vertonen dan de acountants behorende tot de waanemings- en oordeelsvomingindex combinaties NF en SF.

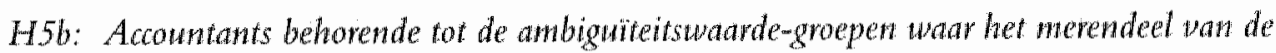
accountants in vertegenwoordigd zijn zwllen weerconsensus vertonen dan de accountan is vertegenwoordigd in de andere ambigurteitswarde-groepen.

\subsection{2. "Voorkeur' van de accountant}

De tweede onderzoeksvraag zoals gesteld in hoofdstuk 1 , gaat over de mate waarin de consensus van accountants wordt beinvloed door de 'voorkeur' van de accountant voor een soort interne beheersingsmatregel. Zoals eerder is angegeven is deze "voorkeur" een proxy voor het soort beheersingsmaatregel dat de grootste bijdrage levert aan het prototypisch mentaal model gericht op de beoordeling wan administratief-organisatorische processen.

De tweede onderzoekswraag luidt: 
V2: Is de voorkeur van de accoumants woor een bepald soort beheersingsmatregel wan invloed op de consensus in de oordelen?

De vraagstelling impliceert een verdeling van de onderzoeksgegevens op basis van de door de accountants opgegeven voorkeur voor een soort interne beheersingsmaatregel. De oordelen wan de bij het onderzoek betrokken accountants worden gesplitst in twee groepen:

- oordelen door accountants gegeven over casusstellingen met een soort beheersingsmatregel dat een grote bijdrage levert aar het prototypisch mentaal model van de accountant gericht op de beoordeling van administratief-organisatorische processen; hiema weergegeven als de voorkeur van de accountant hebbend; en

- oordelen door accountants gegeven over casusstellingen zonder het soort beheersingsmaatregel dat de grootste bijdrage levert aan het prototypisch mentaal model van de accountant gericht op de beoordeling van administratief-organisatorische processen; hierna weergegeven als niet de voorkeur van de accountant hebbend.

Ofschoon de accountant die het systeem van administratieve organisatie moet beoordelen een eigen voorkeur heeft voor de beheersingsmatregelen, moet hij de Richtijnen voor de Accountantscontrole (RAC 400) [NIVRA, 2003] volgen. De RAC 400 bevat voorschriften aangaande het verkrijgen van voldoende inzicht in de administratieve organisatie en interne beheersing. Deze voorschriften zijn verplicht voor de accountant in het kader wan de controle van de jaarrekening. Hoe de accountant zijn afwegingen moet maken bij het aantreffen van interne beheersingsmaatregelen is daarbij niet voorgeschreven. Hiervoor zal hij terugvallen op wat hiervoor is genoemd zijn prototypisch mentaal model.

In dit onderzoek worden vijf soorten van beheersingsmaatregelen onderkend:

- Procesbeheersing;

- Financiele beheersing;

- Organisatorische beheersing;

- Informatiebeheersing;

- Prestatiebeheersing.

Wanneer de accountant wordt gevraagd een volgorde van belargrijkheid aan te geven voor deze vijf soorten van beheersingsmatregelen wordt geappelleerd aan het kennissegment 'episodic procedural knowledge' met als representatie het prototypisch mental model van de accountant gericht op de beoordeling van administratief-organisatorische processen en als proxy 'voorkeur'. De accountant zal daarbij een voorkeur hebben voor die soort beheersingsmaatregel dat de grootste bijdrage levert aan het prototypisich mentaal model [Rosch, 1978]. 
Op grond van de ontwikkeling van de prototypische mentale modellen met daarin kennis over de vijf soorten beheersingsmaatregelen kan de zesde hypothese worden geformuleerd. Deze hypothese is gericht op de relatie tussen de 'intermediate'-output variabele 'Kennis' en 'Professional Judgment', met als proxy 'consensus', en luidt:

H6: Accountants zullen in hum oordelen meer consensus pertonen natuate beheersingsmaatregelen woorkomen waakan zij de 'voorkeur' geven.

\subsubsection{Het psychologische profiel van de accountant.}

De derde onderzoeksvraag zoals gesteld in hoofdstuk 1, gaat over de evaluatie van de accountant zelf en luidt:

V3: Wijkt het psychologische profiel van de accountants die meegewerkt hebben aan deze stwdie af wan dat yan accountants die hebben meegewerkt aan andere soortgelijke studies?

In hoofdstuk 1 is stilgestaan bij de internationale en nationale ontwikkelingen binnen de accountantsprofessie, gericht op het beoordelen van de toereikendheid van administratief-organisatorische processen. Door de ontwikkelingen op het gebied van corporate governance worden van de accountants verklaringen gevraagd ter bevestiging van de beweringen die het management heeft gedaan over het 'in control zijn' van de onderneming [Sarbanes-Oxley Act, 2002]. Het Panel on audit effectiveness [Public Oversight Board, 2000] alsmede de nieuwe in ontwikkeling zijnde audit risk-standaarden van IFAC bevestigen deze ontwikkeling en geven aanbevelingen die deze ontwikkeling versterken, onder meer door ansluiting te zoeken met het COSO-model [COSO 2004, 1992]. Ook de controlemethodologieën van de diverse accountantskantoren worden steeds opnieuw bijgesteld naar deze visies en ontwikkelingen. Het handhaven van de onafhankelijkheid bij de controle van de jaarrekening blijft daarbij steeds voorop staan. De accountant zal dus steeds meer procesgericht moeten denken en de toereikendheid van de administratief-organisatorische processen moeten vaststellen. Voorts wordt de opleiding tot registeraccountant steeds opnieuw op deze ontwikkelingen aangepast. Een visitatiecommissie, die is ingesteld door de Minister van Onderwijs, Cultuur en Wetenschappen, beoordeelt de aanpassingen van de inhoud en kwaliteit van de opleiding. Deze visitatiecommissie onderwerpt de opleidingen met een vaste regelmaat aan een onderzoek, rapporteert hieromtrent en geeft aanwijzingen tot verbetering.

Dat de hiervoor beschreven ontwikkeling nog niet totstilstand is gekomen, getuigen recente rapporten [Winter, Garrido Garcia, Hopt, Rickford, Rossi, Schans Christensen en Simon, 2002; Gregory en Simmelkjaer, 2002]. Door deze veranderingen 
in de wijze van werken en denken van de accountant zou een verandering in de persoonskarakteristieken van de accountant waarneembaar kunnen zijn.

Bij de theoretische beschouwing voor de input variabele 'Aanleg' is aangegeven dat. in dit onderzoek een psychologische test gebaseerd op de typologie van Jung gehanteerd kan worden. Deze test is in het verleden regelmatig gebruikt waarbij de onderzoeksresultaten volgens een standaardmethode inzichtelijk zijn gemaakt. De uitkomsten van andere onderzoeken waarbij dezelfde psychologische test is gehanteerd kunnen vergeleken worden met de vitkomsten van dit onderzoek.

De zevende hypothese kan worden geformuleerd door de psychologische test die de bij het onderzoek betrokken accountants hebben ingevuld te vergelijken met uitkomsten van dezelfcle psychologische test uit vergelijkbare voorgaande onderzoeken. Doordat de onderzoekspopulatie in de verschillende onderzoeken niet dezelfde is geweest, is hierbij geen sprake van een longitudinaal onderzoek. De zevende hypothese is gericht op de input variabele 'Aanleg' en luidt:

H7: De veranderende wijze van werken en denken van de accountant doet een verandering verwachten in de persoonlijkheidskarakteristieken van de accountants in dit onderzoek. ten opzichte vain accosntants in vergelijkbare onderzoeken.

\subsubsection{Samenvatting hypothesevorming}

Zeven hypotheses zijn geformuleerd die invulling moeten geven aan de drie gestelde onderzoekswragen. De eerste twee onderzoeksvragen, en de daarbij ontwikkelde zes hypotheses, hebben betrekking op het bestaan van 'Professional Judgment' waarbij 'consensus' gezien wordt als een proxy. Dat veel aandacht gegeven wordt aan 'consensus' als proxy voor 'Professional Judgment' sluit aan bij de bevindingen van Solomon en Shields [1995] die dit als passend beschouwen. Solomon en Shields [1995] stellen dat het verwijzen naar gelijkluidende oordelen van andere professiomals een belangrijke manier is om een oordeel te rechtvaardigen.

De derde onderzoeksvraag en de zevende hypothese hebben betrekking op de het psychologische profiel van de accountant en de afwijkingen hierin ten opzicht van andere soortgelijke onderzoeken. Door het periodiek in kaart brengen van de persoonlijkheidskarakteristieken van de accountants met behulp van de typologie van Jung, kunnen afwijkingen daarvan worden herkend. Benadrukt wordt dat bij dit onderdeel van het onderzoek gebruik is gemaakt van uitkomsten van andere vergelijkbare onderzoeken. De vergelijking van de persoonlijkheidskarakteristieken heeft dus niet plaatsgevonden tussen dezelfde accountants in de tijd gezien, maar tussen 
verschillende groepen accountants in de tijd gezien. Geen sprake is derhalve van een longitudinaal onderzoek.

In de volgende paragraaf worden de keuzes weergegeven voor de te verzamelen gegevens en de in dit onderzoek te betrekken dimensies van de variabelen uit het model van Libby [1995]. Overeenkomstig de doelstelling van dit onderzoek zijn de te verzamelen gegevens verder ingeperkt door de grenzen van het kennisdomein en de Nederlandse accountantsprofessie. De keuzes van de gegevens zijn mede gebaseerd op de theoretische beschouwingen uit hoofdstuk 2 .

\subsection{Invulling van het model van libby per variabele}

In het vervolg van dit deel van het hoofdstuk wordt, evenals in hoofdstuk 2, gestart met de input variabelen 'Ervaring' en 'Aanleg'. Daarna volgen de 'intermediate"output variabele 'Kennis' en de output variabele 'Kwaliteit accountantsoordeel'.

\subsubsection{Gekozen gegevens en dimensies voor de input variabele 'Ervaring'}

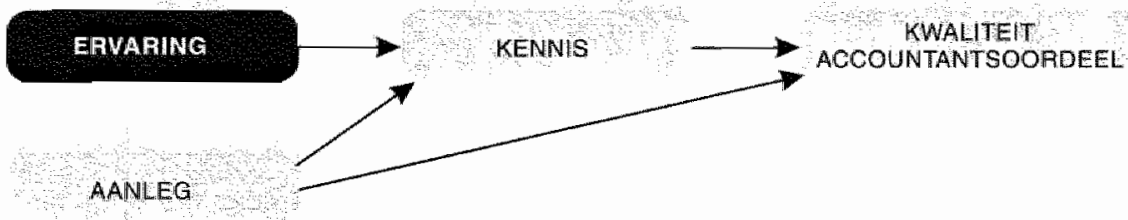

\section{Gekozen dimensies}

Bij het kiezen van de onderzoeksgegevens en de -dimensies voor de input variabele 'Ervaring' is het onderscheid van Libby [1995] in direct gerelateerde en indirect gerelateerde ondervindingen gevolgd.

Deze twee dimensies zijn voor de te verzamelen gegevens als volgt nader ingevuld.

1. Direct gerelateerde ondervindingen; alle gegevens over de cliëntenportefeuille zoals de accountant die bedient.

2. Indirect gerelateerde ondervindingen; alle gegevens over de opleiding en training van de accountant in de brede zin van het woord, zonder dat sprake is van een directe relatie met een concrete opdracht.

Gekozen gegevens ten aanzien van direct gerelateerde ondervindingen

Zoals uit de theoretische beschouwingen in hoofdstuk 2 naar voren is gekomen groeit de kennis van de accountant en wordt deze kennis beter georganiseerd naarmate de accountant langer binnen de accountantsprofessie werkt en meer ervaring 
krijgt [Van Kuijck, 2000; Bédard, 1994; Bédard en Graham, 1994; Bonner en Walker, 1994; Bonner en Pennington, 1991; Bédard, 1989]. De vertrouwensrelatie van een accountant met zijn cliënt wordt gezien als een zeer belangrijk element voor de professionele beroepsuitoefening. Het opbouwen van zo'n vertrouwensrelatie vindt plats gedurende een voor iedere relatie verschillend tijdpad. In deze periode doet de accountant de ervaring op zoals door de genoemde onderzoekers is bedoeld. Conform deze en andere onderzoekers, zoals in hoofdstuk 2 is aangegeven, is dan ook als proxy voor ervaring gekozen voor het gegewen 'aantal jaren werkervaring binnen het vakgebied accountancy". Dit aantal jaren is niet beperkt gebleven tot de periode startend op het moment dat een persoon is afgestudeerd als accountant. Eveneens zijn meegenomen die jaren dat een persoon werkzaam is binnen het vakgebied accountancy tijdens het volgen van de studie tot accountant. Ten behoeve van de verschillende analyses is tevens inzicht gevraagd in de verdeling van de cliëntportefeuille van de accountant.

De volgende gegevens zijn opgevraagd met een voorgeschreven indeling:

- aantal jaren werkervaring in het vakgebied accountancy;

- procentuele verdeling van de cliëntportefeuille naar soort klant;

- procentuele verdeling van de cliëntportefeuille naar klantgrootte;

- procentuele verdeling van de clientportefeuille naar type opdracht.

Gekozen gegevens fen aanzien wan indirect gerelateerde ondervindingen

Zoals in de theoretische beschouwingen in hoofdstuk. 2 al is aangegeven kennen opleiding en ervaring een zeer sterke relatie [Libby, 1995; Bonner en Walker, 1994; Bonner en Pennington, 1991; Bonner en Lewis, 1990; Marchant, 1990; Bédard, 1989]. Tevens is onderscheid gemaakt in twee soorten instructie: formele en informele instructie. De internationale richtijinen voor het curriculum voor de opleiding tot accountant en de in dit onderzoek betrokken doelgroep, welke ten tijde van het volgen van de opleiding geconfronteerd werd met een afrondend centraal landelijk examen, maken dat in dit onderzoek de formele instructie voor iedere accountant als gelijk wordt gezien. Vooral de informele instructie en met name de impliciete informele instructie zullen per accountant verschillend zijn. De impliciete informele instructie is die instructie die ontvangen is vanaf het eerste moment van min of meer bewust leven.

De volgende gegevens zijn opgevraagd met een voorgeschreven indeling:

- aan welk opleidingsinstituut is men afgestudeerd;

- welke overige universitaire of HBO-opleidingen heeft men gevolgd;

- vestigingsplaats van het kantoor van waaruit de werkzaamheden plaatsvinden;

- aantal wisselingen van kantoor; 
- amtal gekwallificeerde kantoorcollega's;

- in welke functie is men momenteel werkzaam;

- in welke functie was men hiervoor werkzaam;

- aan welk opleidingsinstituut wordt gedoceerd;

- in welk vakgebied wordt gedoceerd;

- aantal jaren doceerervaring.

\subsubsection{Gekozen gegevens en dimensies voor de input variabele 'Aanleg"}

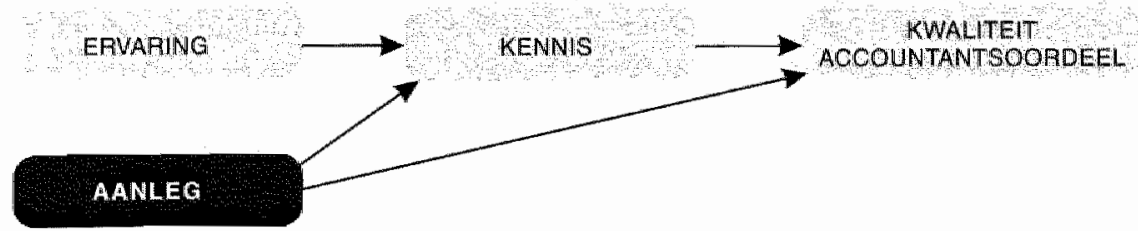

Gekozen dimensies

Libby [1995] geeft bij zijn model betreffende de input variabele 'Aanleg' alleen een drietal voorbeelden die horen bij informatieverwerkende takstellingen gericht op het oplossen van problemen.

\section{Crekozen gegevens}

De moeilijkheden met het meten van de input variabele 'Aanleg' ligt besloten in de omschrijving die Libby [1.995] aangaande deze variabele geeft: een "internal state of mind" waardoor de input variabele 'Aanleg' alleen indirect is te observeren. Zoals eveneens in de theoretische beschouwingen is angegeven is de variabele 'Aanjeg' niet alleen vanuit het probleemoplossend vermogen te observeren. Door een groot aarital onderzoekers wordt een parallel gezien tussen het probleemoplossend vemogen en het besluitvormingsproces. Hierdoor is het mogelijk de variabele "Aanleg" vanuit de psychologie te observeren. Daarbij worden onder meer metingen gedaan naar de cognitieve stijl en de tolerantie voor ambiguite it [Wright en Davidson, 2000; Vaassen, 1993; Chenhall en Morris, 1991; Davis, Grove en Knowles, 1990; Masuch en LaPotin, 1989; Zebda, 1989]. In de theoretische beschouwingen is ook angegeven dat cognitieve stijl onderzoeken veelal worden uitgevoerd met behulp van op de theorie van Jung gebaseerde methoden.

De volgende gegevens zijn opgevraagd door middel van psychologische testen:

- de cognitieve stijl gerelateerd aan de typologie van Jung;

- de mate van tolerantia voor ambiguitteit. 


\subsubsection{Gekozen gegevens en dimensies voor de 'intermediate'-output variabele 'Kennis'}

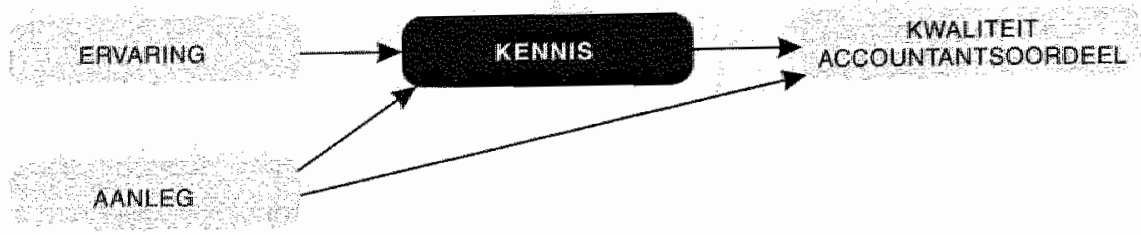

\section{Gekozen dimensies}

Het door Libby [1995] gemaakte onderscheid in kennis en geheugen is zovee mogelijk bij de 'intermediate'-output variabele 'Kennis' gevolgd. In deze studie is dit in-gevuld voor het kennisdomein Bedrijseconomie; Administratieve Organisatie.

\section{Gekozen gegevens}

Everals bij het meten van de input variabele 'Aanleg' ligt de moeilijkheid van meten bij de 'intermediate'-output variabele 'Kennis" besloten in de omschrijving van Libby [1995] aangaande deze variabele. Libby [1995] stelt dat kennis een 'internal state of mind' is waardoor de 'intermediate'-output variabele 'Kennis' alleen indirect is te observeren [Choo en Curtis, 2000]. Als representatie van de "intermediate"-output variabele 'Kennis' wordt gebruik gemakt van het prototypisch mentaal model van de accountant gericht op de beoordeling van administratief-organisatorische processen. Zoals in paragraaf 1.3 is aangegeven is een prototypisch mentaal model een gestructureerde weergave van de door instructie, ervaring en aanleg opgebouwde kennis voor de uitvoering van een specifieke taak [Rosch, 1978; Wright, 1977]. De gegevens en informatie die het prototypische mentaal model structureren hebben verschillende gewichten watmee angegeven wordt de relatieve mate van belangrijkheid. De soort beheersingsmaatregel die de grootste bijdrage heeft aan het prototypisch mentaal model zal de voorkeur hebben voor de accountant. "Voorkeur" wordt dan ook als proxy gezien voor de kennis van de accountant vastgelegd in het prototypisch mentaal model gericht op de beoordeling van administratief-organisatorische processen.

Het volgende gegeven is opgevraagd met een voorgeschreven indeling:

- een ranking naar mate van belangrijkheid van de vijf soorten beheersingsmaatregelen. 


\subsubsection{Gekozen gegevens en dimensies voor de output variabele 'Kwaliteit accountantsoordeel'}

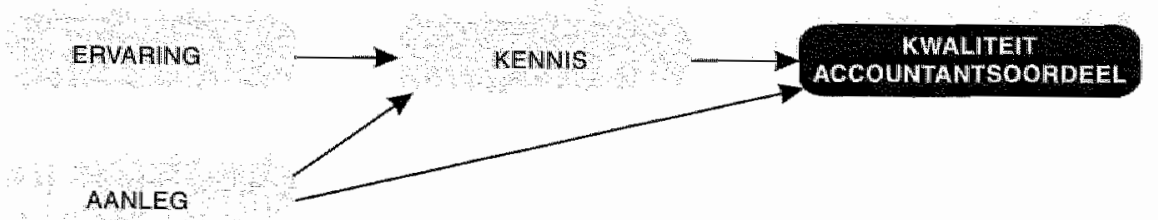

\section{Gekozen dintensies}

Van de door Libby [1995] onderkende twee soorten criteria waartegen de oordelen die gebaseerd zijn op uitgevoerde taken worden afgezet te weten effectiviteit en efficiency, wordt in dit onderzoek alleen ingegaan op de effectiviteit. Het niet ingaan op de efficiency is overeenkomstig de in de afgelopen jaren gedane onderzoeken zoals blijkt uit de overzichtsartikelen van onder meer Solomon en Shields [1995], Bédard en Chi [1993], Vaassen [1993], Choo [1989] en Colbert [1989]. Bij de meting van de effectiviteit wordt een relatie gelegd tussen de uitkomsten van de individuele accountants en de uitkomsten van de andere bij het onderzoek betrokken accountants.

\section{Gekozen gegevens}

Zoals in de theoretische beschouwing is weergegeven, is de kwaliteit van het oordeel dat de accountant geeft, een functie van het prototypisch mentaal model dat door de accountant is gehanteerd. Aan de accountants is dan ook gevraagd een oordeel te geven over de toereikendheid van een administratief-organisatorisch proces. Aangezien dit onderzoek zich richt op het professional judgment van de accountant, is als proxy voor professional judgment gekozen voor 'consensus' in de door de accountants gegeven oordelen. Het 'consensus' criterium is een belangrijk criterium in het door Solomon en Shields [1995] in analogie met Ashton [1983] opgezette framework gericht op de evaluatie van professional judgment.

Naast het vragen van een oordeel werd voor verdere analyses ook gevraagd in hoeverre een dergelijke casusstelling in de praktijk van de accountant voorkwam. Deze vraag werd gesteld ondat hoe vaker een bepaalde situatie voorkomt, hoe groter de invloed is op de prototypisch mentale modellen die de accountant ontwikkelt en waartegen hij de werkelijkheid afzet [Rosch,1978]. Voorts zijn deze gegevenss van belang, zoals weergegeven in paragraaf 2.3.4., omdat alleen ervaren accountants effectief gebruik maken van besluitvormingsheuristieken die gebaseerd zijn op ervaring [Bonner en Lewis, 1990]. Frederick en Libby [1986] stellen dan ook dat 'If the mental model differs berween the expert and the novice, then applying the same representative- 
ness assessment process to the same targer event might lead to decidedly (and predictably) differewt likelihood assessments'.

De volgende gegevens zijn opgevraagd met een voorgeschreven indeling:

- een oordeel over de administratieve organisatie zoals beschreven in de ter beoordeling voorliggende casusstelling;

- een schatting hoe vaak in de praktijk van de bij het onderzoek betrokken accountant de ter beoordeling voorliggende casusstelling voorkomt teneinde inzicht krijgen in de mate van ervaring die de accountant heeft bij de beoordeling van de administratieve organisatie in de voorliggende casusstelling.

\subsubsection{Samenvatting invulling van het model van Libby per variable}

Keuzes zijn gernaakt van gegevens en dimensies die betrokken zijn in het verdere onderzoek. Hierbij is gebruik gemaakt van het model van Libby [1995] en de theoretische beschouwingen zoals beschreven in hoofdstuk 2. De doelgroep waarop het onderzoek zich richt zijn registeraccountants werkzaam als accourtant binnen het openbare beroep.

Het grote belang dat aan de input variabele 'Ervaring' gehecht werd in hoofdstuk 2, te weten dat naarmate de accountant langer werkzaam is binnen de accountantsprofessie en meer ervaring verkrijgt zijn kennis toeneemt en zijn kennisstructuur zich verbetert, blijkt evenzo bij de keuze van de gegevens. Zoals uit de theoretische beschouwingen in hoofdstuk 2 al naar voren was gekomen zijn twee van de vier variabelen, te weten 'Aanleg' en 'Kennis', niet direct te observeren. Voor wat betreft de input variabele 'Aanleg' is aansluiting gevonden bij het gedachtegoed van de cognitieve psychologie. Voor wat betreft de 'intermediate'-output variabele 'Kennis' werd aansluiting gezocht bij de 'voorkeur' die een accountant heeft voor een soort beheersingsmaatregel en als zodanig de grootste bijdrage heeft aan het prototypische mentaal model van de accountant gericht op de beoordeling van administratieforganisatorische processen. Voor de meting van de output variabele 'Kwaliteit accountantsoordeel" is gebruik gemaakt van een casusstelling die de bij het onderzoek betrokken accountants van een oordeel moesten voorzien. Wanneer dit onderzoek ingebracht wordt in het evaluatieframework voor professional judgment van Solomon en Shields [1995] en Ashton [1983] kan het worden gecategoriseerd als een onderzoek gericht op het evaluatiecriterium 'consensus'. 


\section{Noten}

1 Zie hiervoor RAC 400 artikel 2 |NIVRA, 2003].

2 De indeling in soorten beheersingsmaatregelen is afgeleid uit Jans [1994], Hartman [1993], Van Swigchem [1987]. Zoals in hoofdstuk 1 is aangegeven is in het COSO-tapport wan september 1992 een internal control frammework gepresernteerd [COSO 1992]. Als gevolg van het feit dat dit framework ten tijde van het ontwikkeles van de casusstellingern welke in deze siudie zijn gehlantee rd nog nier die bekendheid genoot als tegenwoordig en dit framework nog niet langijarig in de opleiding tot accountant was ingebed is niet gekozen voor her hanteren van deze indeling. Aansluiting is gezoch bij de terminologic an indeling die langjarigg in de opleiding tor accountant zijn gehanteerd en welke als bekend zouden mogen worden veronderstald bij de accountants die in dit onderzoek zijn betrokken.

3 Besluitvaatdigheid is de vertaling wan de tem "decision-making ability".

4 Probleemoplossend wermogen is de vertaling wan de term 'probleon-solving ability'. 


\section{De onderzoeksopzet}

\subsection{Inleiding}

In het voorgaande zijn de internationale en nationale ontwikkelingen binnen het accountantsberoep geschetst voor zover betrekking hebbende op het genoemde kennisdomein. Voorts is een drietal onderzoeksvragen opgesteld, toegespitst op de beoordeling van de toereikendheid van administratief-organisatorische processen in het kader van de beheersing van organisaties. Hierna is, uitgaande van het model van Libby [1995], een theoretische basis gelegd voor de keuze van onderzoeksdimensies en onderzoeksgegevens. Op basis van deze ontwikkelingen en theoretische beschouwingen is vervolgens een aantal hypothesen geformuleerd. Tevens is een keuze gemaakt voor de in het onderzoek te betrekken onderzoeksgegevens. De testen van de hypothesen vormen de basis voor de antwoorden die uiteindelijk op de drie gestelde onderzoekswragen gegeven worden.

De anonimiteit van de accountants die aan dit onderzoek deelnamen is zoveel mogelijk gewaarborgd. Een aantal algemene gegevens werd wel gevraagd om bij de verdere uitwerking van de analyses de mogelijkheid te bieden van verschillende stratificaties.

Deze gegevens betroffen:

- geboortedatum;

- geboorteland;

- geslacht;

- begindatum werkzame leven.

In dit vierde hoofdstuk wordt ingegaan op de gevolgde onderzoeksopzet. In het onderzoek is aan alle bij het onderzoek betrokken accountants een drietal soorten vragen voorgelegd; twee soorten voor iedereen gelijk en één soort verschillend. De twee soorten vragen die voor een ieder gelijk waren hadden betrekking op demogra- 
fische en achtergrondgegevens alsmede een tweetal psychologische tests. Deze vragen werden schriftelijk per post gesteld met behulp van vragenlijsten.

De soort vraag die verschillend kon zijn voor de bij het onderzoek betrokken accountants heef betrekking op een casusstelling. Deze casusstelling omvat een administratief-organisatorische procesbeschrijving, waarover de accountants een oordeel moesten uitspreken. Deze casusstelling is gebaseerd op een vast basismodel en varieert qua inhoud. Dit wordt gerealiseerd door de in het vorige hoofdstuk genoemde vif $f$ soorten beheersingsmatregelen in verschillende combinaties op te nemen in de casusbeschrijving die aan de accountants worden gepresenteerd. Teneinde de van de accountants ontvangen oordelen te kunnen analyseren, dient dit variëren met de beheersingsmaatregelen op een gecontroleerde wijze plaats te vinden.

Gestart wordt in dit hoofdstuk met een keuze van het onderzoekstype. Vervolgens worden de verschillende onderzoeksinstrumenten behandeld die in het onderzoek zijn gehanteerd. Dit betreft de vragenlijsten, de casusstelling en de psychologische tests. Daarna wordt een beschouwing gegeven van de antwoorden die verkregen zijn van de deelnemende accountants. In hoofdstuk 5 worden vervolgens de onderzoeksresultaten weergegeven alsmede de antwoorden op de geformuleerde hypothesen, warna in hoofdstuk 6 de onderzoekswragen worden beantwoord.

\subsection{Gekozen onderzoekstype}

In hoofdstuk $\mathbb{l}$ is een drietal onderzoeksvragen geformuleerd ${ }^{1}$. De eerste twee vragen hebben betrekking op professional judgment met als proxy "consensus'. De derde vraag richt zich op de persoonlijkheidskarakteristieken van de accountant. Om antwoord te kunnen geven op de eerste twee onderzoeksvragen worden de onderzochte variabelen met elkaar in verband gebracht. Dit heeft tot doel het bestaan van professional judgment bij de beoordeling van administratief-organisatorische processen door de accountant aan te tonen. Om antwoord te kunnen geven op de derde onderzoeksvraag wordt een antal eigenschappen van de bij het onderzoek betrokken accountants met elkar in verband gebracht en wordt nagegaan of het psychologiscli profiel van de accountants in deze studie afwijkt van dat uit soortgelijke studies. Aangezien variabelen en onderzoeksgegevens met elkaar in verband worden gebracht met de bedoeling inzicht te verkrijgen in een tweetal verschijnselen kan het onderzoek gekenschetst worden als een verk]arend onderzoek [De Groot, 1994; Zwaan, 1992]. De hoeveelheid verzamelde gegevens alsmede de mogelijkheid om geavanceerde geautomatiseerde hulpmiddelen te gebruiken makt dat het onderzoek uitgevoerd kan worden in de vorm van een comparatief (vergelijkend) onderzoekstype [Zwaan, 1992]. Bestaande theorievorming aangaande professionele oor- 
deelsworming is gehanteerd als vertrekpunt van waaruit de onderzoeksvragen worden bekeken. De variabelen waar het onderzoek zich bij de eerste twee onderzoeksvragen op richt zijn ontwikkeld vanuit het conceptuele model van Libby [1995]. De persoonlijkheidskarakteristieken waar het onderzoek zich bij de derde onderzoeksvraag op richt zijn ontleend aan standaard psychologische tests.

Aangezien het onderzoek zich richt op het judgment van de professionele accountant en diens persoonlijkheidskarakteristieken is dit onderzoek te typeren als een verklarend comparatief survey onderzoek uitgevoerd met de momentopname variant [Zwaan, 1992]. Dit houdt in dat met behulp van het in onderling verband brengen van een groot aantal op een bepaald moment verzamelde gegevens van individuele accountants getracht wordt inzicht te verkrijgen in de twee genoemde verschijnselen, te weten professional judgment en persoonlijkheidskarakteristieken. Ten behoeve van de derde onderzoeksvraag heeft wel een vergelijking plaatsgevonden met onderzoeksgegevens verzameld en geanalyseerd in vergelijkbare onderzoeken verspreid in de tijd; het onderzoek heeft zodoende geen longitudinaal karakter.

In de volgende paragraaf worden de onderzoekspopulatie en de gehanteerde vastleggingstechnieken beschreven.

\subsection{Onderzoeksinstrumenten}

Bij dit onderzoek is een drietal verschillende onderzoeksinstrumenten gehanteerd, te weten vragenlijsten, casusstellingen en psychologische tests. De vragenlijsten en de casusstelling zijn specifiek ontwikkeld voor dit onderzoek. Bij de psychologische tests werd gebruik gemaakt van langjarig in gebruik zijnde standaard vragenlijsten gericht op de Myers-Briggs Type Indicator en de Tolerance for Ambiguity test A T. 20 Scale. Alvorens nader in te gaan op de specifieke onderzoeksinstrumenten wordt eerst een kort overzicht gegeven van de meer technische kanten van het onderzoek. Het betreft hier de onderzoekspopulatie, de wijze van benaderen van deze onderzoekspopulatie en de gehanteerde vastleggingstechnieken. Vervolgens wordt de opbouw van de vragenlijsten in het kort besproken. Daarna wordt stilgestaan bij de ontwikkeling van de casusstelling, de daarbij gedane aannames en gemaakte keuzes alsmede de variaties welke in het beheersingsinstrumentarium zijn doorgevoerd om de verschillende te beoordelen casusstellingen te kunnen samenstellen. Voor een korte samenvatting van de gehanteerde twee psychologische tests wordt verwezen naar paragraaf 2.5 . 


\subsubsection{Onderzoekspopulatie en vastleggingstechnieken}

\subsubsection{Onderzoekspopulatie}

Zoals in hoofdstuk 1 is uiteengezet vormt de beoordeling van de toereikendheid van administratief-organisatorische processen in het kader van de beheersing van een organisatie een essentieel onderdeel van de werkzaamheden van de accountant. Nationale en intemationale regelgeving voor de uitvoering van de controleopdrachten kennen een antal verplicht te volgen richtlinen op dit punt. In de opleiding tot accountant is het vak Administratieve Organisatie éen van de twee kernvakken, dat, in de tijd dat de accountants die an deze studie hebben meegewerkt hun opleiding volgde, getoetst werd met een central landelijk examen.

On te komen tot een zo homogeen mogelijke onderzoekspopulatie is als een van de selectiecriteria gesteld dat de in het onderzoek betrokken personen minimaal het vakgebied Administratieve Organisatie met positief gevolg moesten hebben afgelegd. Teneinde deze zekerheid te verkrijgen is een beroep gedaan op de openbare registers van het Koninklijk NIVRA waarin alleen afgestudeerde accountants opgenomen zijn. Tevens heeft het onderzoek zich uitsluitend gericht op accountants die werkzaam zijn binnen de openbare praktijk in Nederland. Samengevat hebben als selectiecriteria voor de bij het onderzoek betrokken accountants gegolden:

- ingeschreven zijn in het register van het Koninklijk NIVRA als bewijs voor het met goed gevolg afgerond hebben van het vak Administratieve Organisatie; en

- werkzaam zijn als openbaar accountant; en

- werkzaam zijn binnen Nederland.

Op basis van deze criteria werd van het Koninklijk NIVRA op 12 mei 1997 een lijst ontvangen met 3928 namen van in haar register ingeschreven accountants allen werkzaam als openbaar accountant in Nederland. In totaal zijn 784 accountants, zijnde $20 \%$, at random geselecteerd en, met behulp van een viertal mailings tussen 17 juni 1997 en 25 augustus 1997, aangezocht aan het onderzoek mee te willen wer$k_{e n}{ }^{2}$. Hierbij werden zij voorzien van de vragenlijsten, een eerste casusstelling en de psychologische tests alsmede een begeleidend schrijven, een gefrankeerde antwoordenveloppe en een aanbevelingsbrief van het Koninklijk NIVRA om aan het onderzoek mee te werken. Bijgeen response heeftgeen follow-up plaatsgevonden.

\subsubsection{Vastleggingstechnieken}

Aan de accountants die aan het onderzoek hebben deelgenomen zijn vragenlijsten, casusstellingen en psychologische tests voorgelegd waarvan de antwoorden zijn verzameld en geanallyseerd. Hierbij is zoveel mogelijk gebruik gemaakt van geautomatiseerde hulpmiddelen. Voorts diende het grote aantal onderzoeksgegevens op een zodanige manier te worden vastgelegd dat zij vanuit verschillende invalshoeken snel en efficiënt benaderbaar bleven. Gekozen is voor het vastleggen van de onderzoeks- 
gegevens in een database structuur. Hierbij diende rekening gehouden te worden met de mogelijkheid de gegevens op een eenvoudige manier te exporteren naar andere softwarepakketten die de analyses ondersteunden ${ }^{3}$.

Zoals in het vorige hoofdstuk is aangegeven heeft de casusstelling betrekking op een administratief-organisatorisch proces met daarin opgenomen beheersingsmaatregelen die in te delen zijn naar een vijftal soorten, te weten:

- Procesbeheersing;

- Financiële beheersing;

- Organisatorische beheersing;

- Informatiebeheersing;

- Prestatiebeheersing.

Bij het ontwikkelen en documenteren van het administratief-organisatorische proces is gebruik gemaakt van een flowchart techniek ondersteund door het geautomatiseerde pakket System Development Workbench, module Administratieve Organisatie (SDW/AO). De uitgebreide set aan controles die door het pakket automatisch worden uitgevoerd maakte het mogelijk een integere set aan flowcharts samen te stellen. Door het opnemen van alle vijf soorten beheersingsmaatregelen ontstond een basismodel. Vanuit dit basismodel was het, met behulp van de met SDW/AO vervaardigde flowcharts, mogelijk de processen tot een zodanig niveau uit te splitsen dat de te onderscheiden activiteiten eenduidig konden worden toegewezen aan enkelvoudig benoemde soorten beheersingsmatregelen. Door het al dan niet opnemen van een soort beheersingsmaatregel konden $2^{5}$ verschillende casusstellingen worden ontwikkeld vanuit het basismodel.

Het data model dat voorafgaande aan de ontwikkeling van de casusstelling is ontworpen om de integriteit van de ontwikkeling te kunnen waarborgen, is in figuur 4.1 weergegeven.

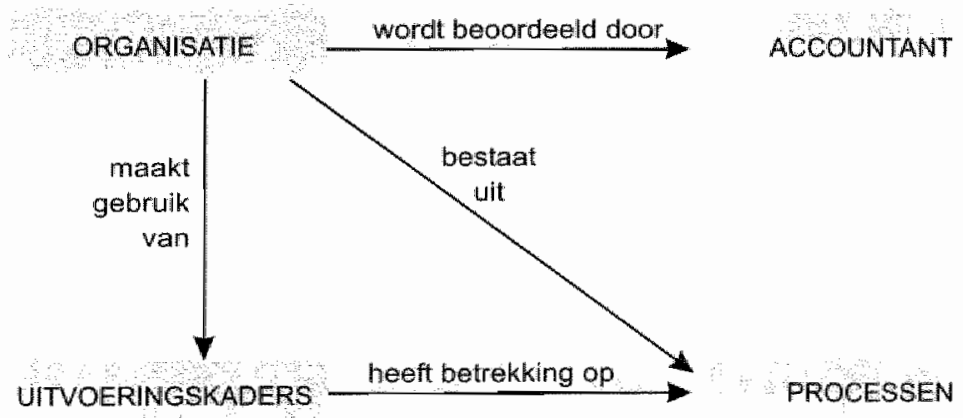

Figutir 4. 1: : Data model 
De entiteitblokken hebben de volgende betekenis:

- organisatie: de entiteit warover het oordeel wordt gegeven gericht op de toereikendheid van het administratief-organisatorisch proces ten behoeve van de beheersing van de organisatie;

- unoeringskaders: beschrijving van de getroffen maatregelen in de omgeving van het administratief-organisatonisch proces, waarmee kaders worden geschapen als noodzakelijke achtergrond wartegen de beoordeling moet platswinden;

- processen: beschrijving van het administratief-organisatorisch proces met de getroffen beheersingsmaatregelen c.q. soorten van beheersingsmaatregelen gericht op de beheersing van de organisatie;

- accountant: beschrijving van de accountant door een beschrijving van zijn eigenschappen en specifieke omstandigheden warin de accountant zich op het moment van beoordeling bevindt.

In bijlage 1 "Data model" is een gedetailleerder data model opgenomen.

\subsubsection{Gehanteerde vragenlijsten}

In hoofdstuk 3 is, op basis van het mode] van Libby [1995], angegeven welke gegevens verzameld moesten worden. Ten behoeve van de verzameling van de gegevens zijn vragenlijsten ontworpen en toegesturird an de accountants in de onderzoekspopulatie. De vragenlijsten zijn zo ontworpen dat zij gekoppeld konden worden aan de variabelen van het model van Libby [1995]. De vragenlijsten zijn in de bijlagen opgenomen volgens de tabel in figuur 4.2.

\begin{tabular}{|c|c|c|c|}
\hline Variabele & Naam vragenlijst & Bijlage & Opmerkingen \\
\hline Ervaring & Demografische gegewens & 2 & Bevat tevens de algemente gegevens \\
\hline Ketunts & Behedsingsinstrumentariun & 3 & $\begin{array}{l}\text { Aangeven varn de "wookeur" voor een } \\
\text { soort beheersingsmaatregel }\end{array}$ \\
\hline \multirow[t]{2}{*}{ Annkig } & Myers-Briggs Type Indicator; & 4 & Standaard vTagenlijst MBTI \\
\hline & Ambiguity Tolerance Indicator & 5 & Standaard vragenlijst AT -20 Scale \\
\hline $\begin{array}{l}\text { Kwallonit } \\
\text { accourntantsonduel }\end{array}$ & Uw oondel & 6 & $\begin{array}{l}\text { Opgenomen aan het einde van de } \\
\text { cassusstelling }\end{array}$ \\
\hline
\end{tabular}

Figuur 4. 2: Vragenlijsten

De vragenlijst met demografische gegevens, zie bijlage 2: 'Demografische gegevens, de vragenlijst", is opgebouwd uit een viertal blokken, te weten:

- Belangrijke data: datumgegevens; 
- Overige belangrijke gegevens: alle overige van belang geachte gegevens met uitzondering van portefeuillegegevens en gegevens inzake doceren;

- Portefeuillegegevens: alleen in te vullen indien werkzaam als openbaar accountant;

- Gegevens inzake doceren: alleen in te vullen indien werkzaan als docent.

Bij deze wragenlijst is geen invulinstructie meegestuurd aangezien bij het merendeel van de vragen standaard antwoordmogelijkheden gegeven waren die geselecteerd konden worden. Door het Koninklijk NIVRA werd aangegeven dat, door de verwerkingstijd van door haar leden doorgegeven wijzigingen, niet op ieder moment alle gegevens uit het register, waaruit de respondenten zijn geselecteerd, $100 \%$ betrouwbaar zijn. Om dit probleem te ondervangen is een aantal vragen opgenomen teneinde de onderzoekspopulatie te valideren.

In het derde blok, gericht op de portefeuille zoals die door de accountant wordt bediend, worden alleen procentuele verdelingen van de portefeuille gevraagd en wel ten aanzien van:

- Verdeling van de klantenportefeuille naar soort klant: een onderverdeling is opgenomen overeenkomstig de indeling die binnen de opleiding in het kernvak Administratieve Organisatie te boek staat als de 'Typologie van Huishoudingen' en die tijdens de opleiding door iedere accountant uit de onderzoekspopulatie als verplichte stof is bestudeerd [Starreveld, De Mare, Joëls, 1997 deel 2a];

- Verdeling van de klantenportefeuille naar klantgrootte: een onderverdeling naar aantal werknemers bij de klant gebruikmakend van een vooraf ingestelde schaal;

- Verdeling van de klantenportefeuille naar type opdracht: in de onderverdeling is naast een zevental vooraf beschreven type opdrachten ruimte gelaten voor het invullen van andersoortige opdrachten.

Aan de accountants is gevraagd om de mate van belangrijkheid, de 'voorkeur', uit te spreken voor de verschillende soorten beheersingsmatregelen, zie bijllage 3: 'Beheersinstrumentarium, de vragenlijst'. In de meegestuurde invulinstructie was aangegeven dat de mate van belangrijkheid kon worden weergegeven met behulp van een cijfer, één per soort beheersingsmaatregel, variërend van 1 (belangrijkst) tot en met 5 (minst belangrijk) waarbij ieder cijfer slechts één maal gegeven mocht worden. Tevens was in de invulinstructie aangegeven dat het hier de mening diende te zijn van de accountant zelve. In de opsomming van de soorten beheersingsmaatregelen was bij iedere soort een voorbeeld beheersingsmaatregel behorende tot die soort opgenomen, te weten:

- Procesbeheersing: zoals interne beheersingsmaatregelen in het proces zelf;

- Financielle beheersing: zoals budgettering;

- Organisatorische beheersing: zoals functiescheiding; 
- Inforwatiobeheersing: zoals standenregisters;

- Prestatiebeheersing: zoals productregistraties en ziekteverzum.

De gehanteerde vragenlijsten met betrekking tot de variabele 'Aanleg' betreffen standaard vragenlijsten zoals die gehanteerd worden bij de psychologische tests zoals beschreven in paragaaf 2.5., bijlage 4: 'Myers-Briggs Type Indicator, de vragenlijst" en bijlage 5: 'Ambiguity Tolerance Indicator, de vragenlijst'. Het betreffen de vragenlijsten behorende bij het formulier $G$ wan de Myers-Briggs Type Indicator [Briggs-Myers en McCaulley, 1990; Briggs-Myers, 1987] en de AT-20 Scale van de door MacDonald [1970] uitgebreide Rydell-Rosen Ambiguity Tolerance Scale [1966]. Beide vragenlijsten zijn dichotomisch wan opzet waarbij tevens een invulinstructie is gegeven.

Met betrekking tot de variabele 'Kwaliteit accountantsoordeel' is slechts een tweetal vragen gesteld naar aanleiding van de casusstelling Personeelszakenproces, zie bijlage 6: 'Personeelszakenproces, de casusstelling'. Enerzijds is gevraagd naar het oordeel van de accountant met betrekking tot de toereikendheid van de administratieve organisatie zoals beschreven in de casusstelling. Hierbij werd een zevental kwalitatieve antwoordmogelijkheden angeboden. Anderzijds is gevraagd naar een schatting door de beoordelende accountant van het percentage dat de door hem beoordeelde casusbeschrijving zich daadwerkelijk in zijn beroepspraktijk voordoet. Hiervoor kon gekozen worden uit een reeks van elf vooraf gedefinieerde percentages, te weten van $0 \%$ tot en met $100 \%$ met intervallen van $10 \%$. In het vervolg van deze paragraaf wordt stilgestaan bij de ontwikkeling van deze casusstelling en de daarbij gemaakte keuzes.

\subsubsection{Gehanteerde casusstelling}

Allereerst wordt ingegaan op de keuzes en overwegingen die hebben gegolden bij het ontwikkelen van de casusstelling inclusief de proceskeuze. Vervolgens wordt in het kort het basismodel van de casusstelling besproken. De volledige casusstelling; het zogenaamde basismodel, is opgenomen onder bijlage 6: 'Personeelszakenproces, do casustelling'. Alvorens met een samenvatting deze paragraf af te sluiten wordt ingegaan op de wijze waarop door het variëren met de soorten beheersingsmatregelen in het basismodel een set van tweeendertig casusstellingen is ontwikkeld. In deze casusstellingen, allen betrekking hebbend op eenzelfde administratief-organisatorisch proces, is sprake van verschillende beheersingssituaties. De wijzigingen in het beheersingsinstrumentarium hebben op een gecontroleerde wijze platsgevonden; ondersteund door SDW/AO. Op deze wijze konden de oordelen, gegeven door de bij het onderzoek betrokken accountants, object van onderzoek zijn in het onderhavige onderzoek. 


\subsubsection{Verantwoording gemaakie keuzes}

De keuzes die zijn gemaakt bij de inrichting van het administratief-organisatorisch proces dat in de casusbeschrijving is opgenomen alsmede de omgeving waarbinnen dit administratief-organisatorisch proces werkzaam is in in het vervolg van deze paragraaf verantwoord. Zoals in voorgaande hoofdstukken is gesteld, is een systeem van beheersingsmaatregelen c.q. de inrichting van een administratief-organisatorisch proces situationeel bepaald. Meservy, Bailey en Johnson [1986] stellen niet alleen dat de verschijningsvorm van een administratief-organisatorisch proces, door het grote netwerk warin beheersingsmaatregelen kunnen samenwerken, situationeel bepaald is. Tevens geven zij aan dat geen eenduidige normstelling bekend is.

Willen de door de accountants gegeven oordelen object kunnen zijn van het onderhavige onderzoek dan dient duidelijkheid te bestaan ten aanzien van de variant van het administratief-organisatorische proces dat de accountant heeft beoordeeld en tegen welke achtergrond deze beoordeling heeft plaatsgevonden.

Bij de keuze van het administratief-organisatorisch proces is zo dicht mogelijk gebleven bij een proces dat door iedere accountant als routinematig beschouwd zal worden. Gekozen is voor het gehele administratief-organisatorische proces dat zich voltrekt op de afdeling Personeelszaken waar onder begrepen het aannemen van personeel, de prestatie beoordeling, het ontslaan van personeel alsmede de gehele financiële afhandeling, de interne controles en de administratieve vastlegging, hierna kortheidshalve te noemen het Personeelszakenproces ${ }^{4}$. Dit administratief-organisatorisch proces wordt in de opleiding expliciet en uitgebreid behandeld. In een aantal eerdere studies is het Personeelszakemproces eveneens gebruikt als basis voor een casusstelling waarin de interne beheersingsmaatregelen werden gevarieerd en aan de accountant om een oordeel werd gevraagd ${ }^{5}$.

De keuze voor het Personeelszakenproces wordt mede verantwoord vanuit de volgende aspecten:

- in praktisch alle organisaties werken mensen in een arbeidsverhouding warvoor aanname en ontslag alsmede loonbetaling plaatsvindt. Dus in al deze organisaties komt het personeelszakenproces voor;

- doordat de loonkosten in het kader van de controle van de jaarrekening in het merendeel van de controles van materieel belang zijn zal het personeelszakenproces bijna altijd object van onderzoek zijn. Derhalve mogen accountants bekend verondersteld worden met dit proces;

- binnen het personeelszakenproces zijn alle relevante functies, acties en beheersingsmatregelen te onderkennen, een ruime mogelijkheid om met beheersingsmaatregelen te variëren is derhalve voorhanden; 
- het personeelszakenproces is binnen een organisatie isoleerbaar; het behoort tot de zogenaamde ondersteunende processen;

- het personeelszakenproces wordt bij het bestuderen van het vak Administratieve Organisatie veelvuldig genoemd vanwege het fraudegevoelige karakter van het proces en dient vaak als voorbeeld bij de beheersing van de administratief-organisatorische actie gericht op het verrichten van periodieke betalingen.

Voor wat betreft de omgeving waarin dit proces zich afspeelt is gekozen voor een zodanige omgeving dat geen belemmeringen bestaan voor het inrichten van een adequat beheersingsinstrumentarium.

Dit heeft geleid tot de keuze wan:

- een middelgrote productieonderneming;

- te typeren als een financieel gezonde onderneming met expansiemogelijkheden;

- producerend in een rustig groeiende markt;

- met 2000 werknemers waarvoor een CAO is afgesloten.

Uitgangspunt is voorts dat het implementeren van beheersingsmaatregelen efficiënt verantwoord is. Daarnaast is zoveel mogelijk voorkomen irrelevante gegevens in de casusbeschrijving op te nemen. Irrelevante gegevens hebben een negatieve invloed op accountants voor wat betreft de consensus in een oordeelsvormingproces al naar gelang de beoordelende accountant beschikt over een mindere mate van ervaring [Shelton, 1999].

In de volgende paragraaf wordt een korte beschrijving gegeven van het basismodel personeelszakenproces. Voor een volledige gedetailleerde beschrijving van het basismodel wordt verwezen naar bijlage 6: 'Personeelszakenproces, de casusstelling'. Dit basisprocesmodel bevat alle vijf soorten beheersingsmatregelen. Vervolgens wordt ingegaan op de variaties die in het beheersingsinstrumentarium zijn doorgevoerd teneinde een zodanige set aan casusstellingen te ontwikkelen dat alle soorten beheersingsmaatregelen in elke mogelijke samenstelling in een van de casusbeschrijvingen
voorkomen.

\subsubsection{Basismodel personeelszakenproces}

Zoals hiervoor is aangegeven is het basismodel van administratieve organisatie ontwikkeld rondom de processen binnen de bedrijffunctie Personeelszaken van een productieondememing. Deze productieonderneming, met een omvang van 2000 CAO gebonden werknemers, kent een aparte afdeling personeelszaken met daarbinnen twee onderafdelingen: het personeelsbureau en de personeelsadministratie. Binnen deze onderafdelingen zijn voldoende functionarissen aanwezig om een optimale functiescheiding efficiënt te kunnen realiseren. Voorts worden de twee onderafdelingen ondersteund met geautomatiseerde informatiesystemen. Alle geautomati- 
seerde informatiesystemen zijn ontwikkeld door een extern softwarehouse dat beschikt over een ISO-9000-certificaat. De softwarepakketten zijn allemaal al een groot aantal keren geimplementeerd. Voor de onderneming zijn geen specifieke anpassingen gemaakt in de software en het onderhoud is uitbesteed aan het softwarehouse.

De informatiesystemen draaien op een mainframe van de onderneming waarbij gebruik wordt gemaakt van een database die door een goede inrichting van de logische toegangsbeveiliging ${ }^{6}$ alleen beschikbaar is voor de daartoe geautoriseerde functionarissen. Mutaties worden in real-time mode verwerkt.

In het personeelsregistratiesysteem (PRS) worden door de onderafdeling personeelsadministratie alle individuele gegevens vastgelegd onder gelijktijdige bijwerking van de standenregisters in het personeelsregistratiesysteem-controle (PRS-C) door de onderafdeling personeelsbureau. Daarnaast functioneren nog:

- het salarisregistratiesysteem (SRS), waarmee de daadwerkelijke bruto / netto berekening wordt gemaakt alsmede de uitbetaling tot stand komt, en

- binnen de afdeling Financiën het financieel registratiesysteem (FRS), waarin de uiteindelijke financiële verantwoording plaatsvindt.

Maandelijks worden binnen de organisatie controles uitgevoerd onder eindverantwoordelijkheid van de financiële administratie, waarbij zowel aan de formele controle $^{7}$ als aan de materiële controle ${ }^{8}$ aandacht wordt gegeven. Hierbij wordt gebruik gemaakt van door de directie vastgestelde taak-en functieomschrijvingen met daarin opgenomen bevoegdhedenschema en daarmee corresponderende handtekeningenen parafenlijsten. Waar mogelijk wordt deze maandelijkse controle ondersteund door vergelijking van de standen in het PRS met het standenregister in het PRS-C. Standaard is dat na iedere controle een rapportage platsvindt ten behoeve van de directie, die daama de beslissing neemt ten aanzien van eventueel te nemen maatregelen. Binnen de onderneming is een volledige audit trail beschikbaar. Alle processen en procedures zijn door de onderneming volledig gedocumenteerd. Voorts geldt binnen de onderneming dat alle extern ontvangen en intern vervaardigde documenten, tenzij anders vermeld, gearchiveerd worden conform de daaraan te stellen wettelijke vereisten.

De onderneming kent de generieke deelprocessen: verkrijging, exploitatie, vervreemding, incasso, excasso. Hierbinnen zijn de in figuur 4.3 weergegeven procedures te onderkennen: 
104 MOOHDSTUK 4

\section{Deelprocessen}

Verkrjging:

Exploitatis:

Verveernding

Hecasso:

Excasso

\section{Procedares}

raming personeelsbehoefte

waststellet wervingsplan

vaststellen wacatures.

werving en selectie

aanmaken arbeidsovereenk omst

werwerken arbeidsovereenkomst

controleren verwerken arbeidsovereenkomsten

muteren stamgegevens

controleren muteren stangegevens

apleiden / trainen

beoordelen functioneren

bevorderen

periodiek muteren loon

controleren bonmutaties

registreren ziekte / verlof

controleren ziekte / verlof

planning personeel / werkuitgifte

vastleggen aanwezigheid personeel

vaststellen prestatic werknemers

controleren anwezigheid

controle overplatsen personeel

ontstain van personeel

controleren wntslag

incasso ziekte-wijkering

controleren incasso zickte-uitkering

vaststet len loongegevens

controleren loongegevens

betalen verschuldigd loon

controleren loonbetaling en afdrachten

journaliseren loonbetallingen

controleren journaliseren lonen

Figuar 43: Deefprocessen en procedures in het basisprocesmodel 
In vorenstaande beschrijving van het personeelszakenproces zijn de vijf generieke deelprocessen uitgesplitst tot tweeëndertig procedures. Een verdere décompositie van de procedures tot tweeëntachtig activiteiten is opgenomen in bijlage 7: 'Processen, procedures, activiteiten en beheersing'. Hierdoor is een basis gelegd om, door op verschillende manieren de soorten van beheersingsmaatregelen te combineren, een set met tweeëndertig casusstellingen samen te stellen, zoals in het hiernavolgende is aangegeven. In de volgende paragraaf wordt beschreven op welke gecontroleerde wijze dit variëren heeft plaatsgevonden.

\subsubsection{Casusstellingen personeelszakenproces}

In hoofdstuk 3 en bij de beschrijving van de gehanteerde vragenlijsten is aangegeven dat in de onderhavige studie de beheersingsmaatregelen naar een vijftal verschillende soorten zijn gegroepeerd. Als beheersingsmaatregelen worden die activiteiten aangemerkt die uitgevoerd worden door de organisatie ten behoeve van de leiding van de organisatie om die leiding in staat te stellen een proces te beheersen. Als soort beheersingsmaatregel zijn samengenomen die beheersingsmaatregelen c.q. activiteiten die een gelijksoortige activiteitendoelstelling hebben. Zoals in hoofdstuk 3 is aangegeven worden de volgende soorten beheersingsmaatregelen onderscheiden:

- Procesbeheersing;

- Financiële beheersing;

- Organisatorische beheersing;

- Informatiebeheersing;

- Prestatiebeheersing.

Om op een beheerste manier te kunnen variëren binnen de context van het gekozen beheersingsinstrumentarium is per activiteit in het basismodel aangegeven aan welke soort beheersingsmatregel deze activiteit gerelateerd is. Uit bijlage 7: 'Processen, procedures, activiteiten en beheersing' blijkt dat van de 82 activiteiten 33 activiteiten niet te relateren zijn aan een van de vijf soorten beheersingsmaatregelen, maar als verplicht zijn aangemerkt. Dit betreft activiteiten die mininaal uitgevoerd moeten worden wil sprake kunnen zijn van een personeelszakenproces. Het samennemen van alleen deze drieëndertig activiteiten creëert een casusstelling. Dit is het verplichte minimum activiteitenmodel, waarin in het geheel geen van de hiervoor genoemde soorten beheersingsmaatregelen is opgenomen. Het omvat de deelprocessen en procedures zoals opgenomen in figuur 4.4 .

Door op een zelfde wijze, op basis van de vijf soorten beheersingsmaatregelen, activiteiten samen te nemen als ten behoeve van het verplichte minimum activiteitenmodel, kan nog een 30-tal verschillende casusstellingen worden ontworpen. In bijlage 8: 'Overzicht casusstellingen met aanwezige beheersingsmaatregelen' is een over- 


\section{Daelprocessem}

Verkrijging:

Exploitatie:

Ververending:

Excasso:

\section{Procedures}

raming personeelsbehoefte

vaststelletn wervingsphan

vaststellerl vacatures

werving en selectie

aammaken arbeidsovereenkomst

verwerken arbeidsoveremkoms

muteren stamgegevens

bevorderen

periodiek muteren loon

planning personeel / werkuitgifte

overplantsen personeel

ontslaan van personeel

Vảststellen loongegevens

betalen werschuldigd loon

journaliseren loonbetalingen

Figuur 4. 4: Dedprocessen en procedures in het verplichte minimum-activiteitemanodel.

zicht van alle casusstellingen opgenomen. Daarbij is aangegeven welke soorten beheersingsmaatregelen wel en welke niet in de casusstelling zijn betrokken.

Voor de casusstellingen wordt de volgende annotatie gehanteerd: OR Oxx \{missende beheersingmaatregelen\}, waarbij OR staat voor Organisatorische Representatie. De missende beheersingsmatregel worden daarbij met de volgende letters aangeduid:

- $\mathrm{P}=$ Proces beheersingsmatregel;

- $\mathrm{F}=$ Financieel beheersingsmaatregel;

- $\mathrm{O}=$ Organisatorisch beheersingsmatregel;

- $\mathbb{I}=$ Informatie beheersingsmaatregel;

- $E=$ Prestatie beheersingsmaatregel.

Een annotatie van OR010 zonder P,O\} impliceert dat in deze casusstelling geen beheersingsmaatregelen zijn opgenomen op het gebied van de Processen en de Organisatie. In het basismodel zijn alle beheersingsmaatregelen aanwezig hetgeen aangegeven is in de annotatie OR001 \{basismodel\}. 
De zo ontwikkelde tweeëndertig verschillende casusstellingen zijn aan de verschillende accountants voorgelegd. Na retour ontvangst van een beoordeelde casusstelling werd een volgende casusstelling aan de accountant toegezonden. De volgorde waarin de casusstellingen aan de accountants zijn voorgelegd is volstrekt at random geweest. Maximaal zijn zes verschillende casusstellingen aan eenzelfde accountant ter beoordeling voorgellegd. Zoals in de volgende paragraaf is angegeven heeft $36,4 \%$ van de accountants betrokken in het onderzoek slechts één casusstelling beoordeeld en 1,5\% zes casusstellingen. Indien een accountant geen casusstelling beoordeeld retoumeerde heeft geen actie plaatsgevonden om alsnog zijn medewerking verder te verkrijgen. Het beoordelen heeft derhalve op een volstrekt vrijwillige basis plaatsgevonden. Bij die accountants die meer dan één casusstelling hebben beoordeeld is geen rekening gehouden met de volgorde waarin de casusstellingen ter beoordeling zijn aangeboden. Ook in de praktijk worden accountants geconfronteerd met te beoordelen administratieve processen in een at random volgorde, soms gelijkend op elkaar, soms totaal verschillend. De ontvangen oordelen zijn tezamen met de annotatie van de casusstelling vastgelegd in een database.

\subsubsection{Samenvatting casusstelling}

Zoals in de inleiding van dit hoofdstuk al is angegeven is aan iedere accountant een aantal casusstellingen voorgelegd. Daarbij werd gevraagd naar het oordeel over de toereikendheid van het in de casusstelling opgenomen administratief-organisatorisch proces ten aanzien van de beheersing ervan. Ondersteund door een daarvoor ontworpen geautomatiseerd systeem is een basisprocesmodel van het personeelszakenproces ontwikkeld. Dit proces is uitgesplitst tot op het niveau waarbij beheersingsmaatregelen rechtstreeks gerelateerd konden worden aan de uit te voeren activiteiten. Door het samennemen van verschillende activiteiten op basis van gemeenschappelijke beheersingsmatregelen kon op een gecontroleerde manier een totale set van tweeëndertig op het aspect beheersing verschillende casusstellingen ontwikkeld worden. Deze casusstellingen zijn vervolgens achter elkaar in een at random volgorde voorgelegd aan de accountants betrokken bij het onderhavige onderzoek.

In de volgende paragraaf wordt eerst ingegaan op de respons van de verzonden vragenlijsten, psychologische tests en casusstellingen. Vervolgens wordt ingegaan op de inhoudelijke kant van de ingevulde vragenlijsten voor zover betrekking hebbende op de karakteristieken van de bij het onderzoek betrokken accountants. Deze paragraaf wordt afgesloten met een eerste beoordeling van de casusstellingen en de bere-kening van de beoordelingswaarden. 


\subsection{Respons}

\subsubsection{Respons in aantallen}

Door 195 accountants werden 527 casusstellingen beoordeeld. Zoals uit bijlage 10: 'Overzicht beoordeelde casusstellingen' blijkt is iedere casusstelling minimaal 12 maal en maximaal 25 maal beoordeeld. De minimale bijdrage van een casusstelling aan de onderzoeksverzameling met casusstellingen bedroeg derhalve $2,3 \%$ en de maximale $4,7 \%$. In de tabe] in figuur 4.5 is aangegeven hoeveel accountants hoeveel casusstellingen hebben beoordeeld. Door 105 van de 195 accountants, 53,9\%, zijn maximaal twee casusstellingen beoordeeld. In figuur 4.5 is de verdeling van de aantallen beoordeelde casusstellingen weergegeven.

\begin{tabular}{|c|c|c|c|c|c|c|c|}
\hline Aantal beoordeelde castusstellingen & 1 & 2 & 3 & 4 & 5 & 6 & Totaal \\
\hline Beoordelende accountants in aantallen & 71 & 34 & 26 & 13 & 48 & 3 & 195 \\
\hline Aurtal beoordeelde casusstellingen & 71 & 68 & 78 & 52 & 240 & 18 & 527 \\
\hline $\begin{array}{l}\text { Cumulatief anual beoordeelde } \\
\text { casusstellingen }\end{array}$ & 71 & 139 & 217 & 269 & 509 & 527 & \\
\hline Beoordelende accountants in percentage & $36,4 \%$ & $17,5 \%$ & $13,3 \%$ & $6,7 \%$ & $24.6 \%$ & $1,5 \%$ & $100 \%$ \\
\hline Cumulitief beoordelende accountants & $36,4 \%$ & $53,9 \%$ & $67,2 \%$ & $73,9 \%$ & $98,5 \%$ & $100,0 \%$ & \\
\hline
\end{tabular}

Figurur 4.5: Respons casusstellingen door accountants

Door 187 van de 195 accountants, 95,9\%, werd een antwoord gegeven op de vraagstelling die gericht was op de "voorkeur" van de accountant.

Door 199 accountants werden de psychologische tests ingevuld welke de basis vormen voor de beantwoording van de vraagstelling gericht op de persoonlijkheidskarakteristieken yan de accountant.

In de tabel in figuur 4.6 zijn de verschillende waarden van de respons weergegeven.

\subsubsection{Demografische gegevens van de respondenten}

Onderstaand wordt inzicht gegeven in de waarden van de diverse gegevenselementen zoals die naar voren komen uit de ontvangen ingevulde vragenlijsten met 'Demografische gegevens'. Eerst wordt ingegaan op de variabelen die in een range zijn onder te brengen. Daarna wordt ingegaan op de overige beschrijvende variabelen gericht op de in het onderzoek betrokken accountants en afsluitend op de variabelen gericht op de portefeuille van die accountant. 


\section{Respons}

\section{Benaderde doelgroep}

Doelgroep volgens opgave van het Koninklije NIVRA

3928

Aantal warzonden whatêtes in onderzok

Verzonden enquêtes in een percentage van de doelgroep

Meewerkende accountants

Aantal beantwoonde enquêtes en / of psychalogische tests

Respons in percentage mailing

Respons in percentage doelgroep

Beoordeelde casusstellingen

Antal beoordeclde casustellingen

Spreiding, minimal - maximaal, over de 32 casustellingen

Minimale bijdrage per casusstelling

Maximalle bijdrage per casusstelling

Gegreven ranking beheersingsmaatregelen

Aantal beantwoorde 'voorkeur' vraggtellingen

Figum 4.6: Responsoverziche

De maatstaven voor ligging en spreiding van de rangevariabelen zien er als volgt uit:

\begin{tabular}{|c|c|c|c|c|c|c|}
\hline Variabele & $\mathrm{Nan}-\mathrm{tot}$ & Range & Mean & $\begin{array}{l}\text { Standarat } \\
\text { deviatie }\end{array}$ & Median & Mode \\
\hline Leetijd & $25-77$ jaar & 52 jati & 40 jar & 8,9 & $38 \mathrm{jaar}$ & 31 jar \\
\hline Workervaring & $0-50$ jaar & 50 jar & 18 jam & 9,4 & $17,5 \mathrm{jah}$ & 9,9 jatar \\
\hline Kantoorwisseling & $0-6$ maal & 6 mand & 2 maal & 11,7 & I maal & 0 maal \\
\hline Kantoorcollega"s & $1->100 \mathrm{RA}^{\prime} \mathrm{s}$ & $>100 \mathrm{RAs}$ & $11-25 R^{n} s$ & 1,7 & $11=25 \mathrm{RA}^{*}$ & $>100 \mathrm{RA}$ \\
\hline
\end{tabular}

Figuar 4.7: Ligging en spreiding rangevariabelen

Op basis van de overige ontvangen gegevens zijn de volgende observaties te maken:

- vestigingsplaats:

de in het onderzoek betrokken accountants waren werkzaam in 61 verschillende vestigingsplaatsen met een maximum van 23 accountants in één vestigingsplaats, te weten Amsterdam; 
- werlezam in worige functic:

van 78 van de 199 accountants, zijnde $39,2 \%$, bleek de informatie niet voorhanden;

- overige universiaine of $\mathrm{HBO}$-opleiding:

99 van de 199 accountants, zijnde $49,7 \%$, heeft antwoord gegeven op de vraag naar een gevolgde overige opleiding. Hierbij werd en twintigtal verschillende opleidingen genoemd; in 39 gevallen betrof dit een opleiding op HEAO-niveau en in 22 gevallen een bedrijseconomische opleiding;

- docerervating:

42 van de 199 accountants, zijnde $21,1 \%$, bleek over doceerervaring te beschikken, tussen de 1 en de 17 jarr;

- dacerew in welke walkgebied:

van de 42 accountants doceren 16 accountants het vakgebied Administratieve Organisatie en 15 accountants het vakgebied Leer van de Accountantscontrole. De overige 11 accountants doceerden in aanpalende vakgebieden;

- doceren aan welke opleiding:

24 accountants doceren aan een universiteit, 7 aan de NIVRA-Nyenrode opleiding, de overige 11 accountants an overige opleidingen.

Gelet op de relatief kleine groep accountants, de grote spreiding in de jaren doceer ervaring, de vakgebieden en de opleidingen war gedoceerd wordt zijn deze gegevens niet verder gehanteerd in het onderzoek en alleen opgenomen om een beter beeld te krijgen van de groep accountants die aan onderzoek hebben meegewerkt.

In figutur 4.8 zijn de overige beschrijvende variabelen gericht op de accountant opgenomen.

\begin{tabular}{|c|c|c|c|c|}
\hline Variabele & 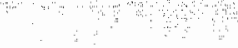 & Wando & & Aantal \\
\hline Geboorteland & $98 \%$ in Nederland & $2 \%$ butren Nederland & & 199 \\
\hline Gestart in accountancy & $85,9 \%$ direct & $14{ }_{n} 1 \%$ niet dired & & 199 \\
\hline Geslacher & $94 \%$ mannelijk & $6 \%$ vrouwelijk & & 199 \\
\hline $\begin{array}{l}\text { Werkzan in het } \\
\text { openbaar boroep }\end{array}$ & $95,5 \%$ wel & $4,5 \%$ niet & & 199 \\
\hline Afgestudeerd an & $\begin{array}{l}56,3 \% \text { NIVRA- } \\
\text { Nyenrode }\end{array}$ & $42,7 \%$ Unwersiteit & $1,0 \%$ overige & 199 \\
\hline
\end{tabular}

Figur $4.8:$ Overtge beschrivende varibbaten

De $4,5 \%$ van de accountants die niet werkzaam zijn in het openbaar beroep hebben aangegeven recentelijk met pensioen te zijn gegaan maar voorafgaande aan deze pen- 
sionering in het openbaar beroep werkzaam te zijn geweest. Om deze reden zijn deze accountants niet uit de onderzoekspopulatie verwijderd.

Met betrekking tot de variabelen gericht op de portefeuille van de accountant is door de accountants een procentuele inschatting gegeven van de verdeling van de portefetrille naar een drietal gezichtspunten, te weten:

\section{Naar type klant:}

een onderverdeling conform de 'Typologie van Huishoudingen' [Starreveld, De Mare, Joëls, 1997 deel 2a];

2. Naar soort opdracht:

een onderverdeling naar een soort opdracht zoals controle, samenstel, beoordeling, advies, EDP-audit, Milieu-audit, Operational-audit en Overige opdrachten;

3. Naar klantgrootte:

een onderverdeling naar aantal werknemers bij de klant gebruikmakend van een vooraf ingestelde schaal;

De verdeling van de inhoud van de variabelen gericht op de portefeuilles van de 199 accountants ziet er als volgt uit:

\begin{tabular}{|c|c|c|c|c|c|}
\hline \multicolumn{2}{|l|}{ Type ondeneming } & \multicolumn{2}{|l|}{ Soort opdracht } & \multicolumn{2}{|l|}{ Grootite client } \\
\hline Handel & $18,6 \%$ & Controleopdrachten & $62,8 \%$ & $0-10$ werknemers & $11,0 \%$ \\
\hline Industrie & $22,1 \%$ & Samenstelopdrachten & $9.6 \%$ & $11-100$ werknemers & $30,1 \%$ \\
\hline Agrarische bedrijven & $1,5 \%$ & Beoordelingsopdrachten & $1,0 \%$ & $101-250$ werknemers & $12,1 \%$ \\
\hline Dienstverlening & $16,6 \%$ & Adviesopdrachten & $6,6 \%$ & 251 - 1000 werknemers & $15,1 \%$ \\
\hline Financiele instellingen & $15,1 \%$ & EDP-audit-opdrachten & $7,5 \%$ & $>1000$ werknemers & $19.6 \%$ \\
\hline Rijksoverheid & $2,5 \%$ & Milien-audit-opdrachten & $0 \%$ & Geen opgave & $12,1 \%$ \\
\hline Lagrere overheid & $5,0 \%$ & $\begin{array}{l}\text { Operational-audit-- } \\
\text { opcrachten }\end{array}$ & $0 \%$ & & \\
\hline $\begin{array}{l}\text { Stuchtingen / } \\
\text { verenigingen }\end{array}$ & $6,0 \%$ & Overige opdrachten & $7,5 \%$ & & \\
\hline Geen opgave & $12,6 \%$ & Geen opgave & $5,0 \%$ & & \\
\hline Totaal & $100 \%$ & Totaal & $100 \%$ & Total & $100 \%$ \\
\hline
\end{tabular}

Fugur 4.9: Portefeullevariabelen

\subsubsection{Beoordeling casusstellingen nader bezien}

Zoals in paragraaf 4.3.3. is aangegeven, is gebruik gemaakt van een groot aantal verschillende casusstellingen gebaseerd op een basismodel ${ }^{9}$. Aan de bij het onderzoek betrokken accountants werd gevraagd naar een oordeel over de administratieve organisatie zoals beschreven in de aan de accountant voorgelegde casusstelling, Voor 
het antwoord kon een keuze gemaakt worden uit de waarderingen 'Uitstekend', 'Zeer goed", 'Goed', "Voldoende", 'Onvoldoende', 'Slecht' en 'Zeer slecht', een zevenpuntsschaal [Tabor, 1983]. Naar een motivering van de gemaakte keuze werd niet gevraagd, ofschoon wel rumte werd gegeven tot het maken van opmerkingen. Door te varieren met de beheersingsmaatregelen ontstond een 32 -tal verschillende casusstellingen $^{10}$. Een overzicht van de casusstellingen en de daarin opgenomen beheersingsmaatregelen is opgenomen in bijlage 8: 'Overzicht casusstellingen met aanwezige beheersingsmatregelen'. In figuur 4.10. is in samengevatte vorm het aantal opgenomen beheersingsmatregelen weergegeven in relatie tot de casusstellingen.

\section{Casusstellingen}

OROO1

OROO2: OROO6

OROO7 $/ \mathrm{mm}$ OR0016

OR0017\% ORO026

OR0027 t/m OR003

OR0032

\section{Aantal soonten beheersingsmaatregelen}

WEL opgenonen

5

4.

3

23

1.4

0
NTET: opgenomen

0

1

2 5

Figun 4.10: Casusstellingen, opgenomen beheersingsmaatregelen

Tevens werd gevragd een schatting te geven hoe vaak de beoordelende accountant in zijn praktijk een personeelszakenproces tegenkomt dat sterke gelijkenis vertoont met de door hem beoordeelde casusstelling, hierna genoemd het 'Voorkompercentage". Voor het antwoord op deze inschatting kon in dit onderzoek gebruik gemakk worden van een voorgeschreven waarderingen in procenten startend met $0 \%$ en oplopend met 10\%. In bijlage 11: "Verdeling Voorkompercentages per casusstelling" is de volledige verdeling weergegeven.

In het onderzoek is aandacht gegeven aan dit 'Voorkompercentage' aangezien dit een verklarende variabele zou kumnen zijn in de beantwoordingen die door de accountants zijn gegeven. Hierbij is uitgegaan van de redenering dat, indien een bepaalde situatie regelmatig terugkerend is, er sprake is van een groter procedural knowledge ${ }^{\prime 1}$. Zoals in hoofdstuk 2 is uiteengezet worden op basis van deze 'procedural knowledge' door de accountant wuistregels en heuristieken ontwikkeld die hij bij een latere beoordeling van een gelijksoortige situatie zal hanteren. Deze redenering is overeenkomstig de theorie van het leren, waarin uitgegaan wordt van de stelling dat een persoon slechts iets kan leren indien daarbij sprake is van een zekere mate van voorkennisactivatie. Indien de voorkennis niet wordt geactiveerd dan zal slechts in 
verminderde mate kennis worden opgebouwd. Dit uitgangspunt inzake voorkennisactivatie is congruent aan het uitgangspunt inzake feedback ${ }^{12}$ [Brown en Solomon, 1991; Davis en Solomon, 1989]. Op deze wijze wordt het prototypisch mentaal model vorm gegeven dat gebruikt wordt voor de uitvoering van een specifieke tak in dit geval het beoordelen van een administratief-organisatorisch proces [Rosch, 1978; Wright, 1977].

\subsubsection{Beschonuing gegeven antwoorden}

In totaal werden 527 casusstellingen beoordeeld welke over de 32 beschikbare casusstellingen verspreid waren. Bij een tweetal casusstellingen ${ }^{13}$ werd het minimum aantal beoordelingen van 12 uitgevoerd. Het maximale aantal beoordelingen bedroeg 25 en vond plaats bij één casusstelling ${ }^{14}$.

In figuur 4.11 is een grafiek opgenomen met zowel de verdeling van de ontvangen en beoordeelde casusstellingen als ook de verdeling van het voorkompercentage $0 \%$.

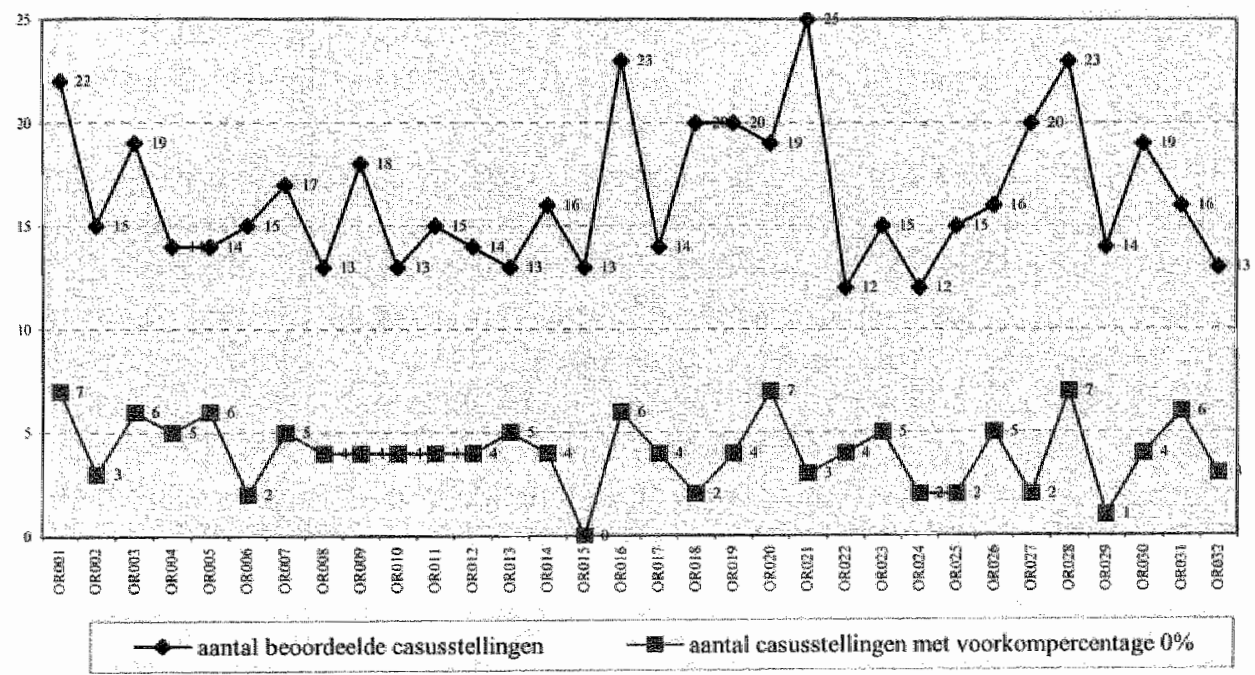

Fuguur 4.11: Aantal ontwangen beoordeelde cosusatellingen (cotal 527) en Voorkompercentage 0\% (cotal 130)

Bij 130 van de 527 uitgevoerde beoordelingen, zijnde $24,7 \%$, werd door de beoordelaar aangegeven dat een dergelijk Personeelszakenproces in zijn praktijk niet voorkwam (voorkompercentage $=0 \%$ ). Met uitzondering van de casusstelling OR 015 \{zonder $O, E\}$ komt deze situatie bij alle 32 casusstellingen voor. Het maximum van 7 beoordelingen met een voorkompercentage $0 \%$, (niet in de praktijk voorkomend) komt voor bij een drietal casusstellingen, te weten: 
1. OR001 \{basismodel\} 7 van de in totaal 22 gegeven beoordelingen derhalve $31,8 \%$

2. OR020 zonder $P, F, E\} 7$ van de in totall 20 gegeven beoordelingen derhalve $35,0 \%$;

3. OR028 zonder $\mathrm{P}, \mathrm{O}, \mathbb{1}, \mathrm{E}\} 7$ van de in total 23 gegeven beoordelingen derhalve $30,4 \%$.

In bijlage 12: 'Overzicht beoordeelde casusstellingen en beheersingsmaatregelen' is aangegeven welke beheersingsmaatregelen bij de beoordelingen betrokken zijn geweest. Doordat in het merendeel van de casusstellingen meer dan één beheersingsmaatregel is opgenomen zijn in totaal $1311(100 \%)$ beheersingsmaatregelen in de beoordelingen betrokken geweest en wel als volgt verdeeld:

- Procesbeheersing $(\mathrm{P})$ :

- Financiële beheersing (F):

- Organisatorische beheersing $(\mathrm{O})$ :

- Informatiebeheersing (I):

- Prestatiebeheersing (E): in 252 beoordelingen zijnde $19,2 \%$; in 263 beoordelingen zijnde $20,1 \%$; in 265 beoordelingen zijnde $20,2 \%$; in 267 beoordelingen zijnde $20,4 \%$; in 264 beoordelingen zijnde $20,1 \%$.

In bijlage 13: 'Overzicht gegeven waardeoordelen en consensuswaarden' zijn de door de accountants gegeven oordelen in aantallen en procentueel weergegeven. Hierbij is de beoordelingsschaal gehanteerd, een zeven-puntsschaal, zoals die was opgenomen op het antwoordformulier. Daarbij werden onderscheidden de waarderingsmogelijkheden 'Uitstekend', 'Zeer goed', 'Goed', 'Voldoende", 'Onvoldoende', 'Slecht' en 'Zeer slecht'. Bij de beoordeling van iedere casusstelling is gebruik gemaakt van de geboden range aan waarderingsmogelijkheden. Van de maximaal 224 ter beschikking staande verschillende waarderingsmogelijkheden ${ }^{15}$ zijn 156 waarderingsmogelijkheden daadwerkelijk gebruikt, zijnde 69,6\%.

Uit bijlage 13: 'Overzicht gegeven waardeoordelen en consensuswaarden' blijkt dat bij geen van de casusstellingen een eensluidende waardering is gegeven. Het minimum aantal gegeven verschillende waarderingen betreft drie van de zeven waarderingsmogelijkheden. Het maximale aantal verschillende waarderingen bedraagt zes. De verdeling van het aantal gegeven verschillende waarderingen over de casusstellingen is weergegeven in figur 4.12 .

Zoals uit de tabel in figuur 4.12. blijkt kennen ook de meest uiterste casusstellingen een meervoudige wardering. De casusstelling waarin alle beheersingsmaatregelen opgenomen waren, te weten OR001 \{basismodel\} kende een viertal verschillende waarderingen. De casusstelling waarin in het geheel geen beheersingsmaatregel was opgenomen OR032 zonder P,F,O,I,E\} kende een drietal verschillende waarde- 


\begin{tabular}{|c|c|c|c|c|c|}
\hline $\begin{array}{l}\text { Aantal } \\
\text { Waarde- } \\
\text { ragen }\end{array}$ & $\begin{array}{l}\text { Anntal } \\
\text { Anses } \\
\text { Arrdelen }\end{array}$ & Cast & tellingen $(32)$ en ata & tal beoordellingen & $(527 x)$ \\
\hline 3 & $2 / 31 \mathrm{x}$ & $\begin{array}{l}\text { (18x) ORO09) } \\
\text { (zonder P,Fl }\end{array}$ & $\begin{array}{l}(13 \mathrm{x}) \text { ORO32 } \\
\text { fander } \mathrm{P}, \mathrm{F}, \mathrm{O}, 1, \mathrm{E})\end{array}$ & & \\
\hline \multirow[t]{2}{*}{4} & $7 / 120 x$ & $\begin{array}{l}(22 x) \text { OROO1 } \\
\text { \{basismodely }\end{array}$ & $\begin{array}{l}(19 x) 0 R 003 \\
\{\text { zonder } 1\}\end{array}$ & $\begin{array}{l}(15 x) \text { OROO6 } \\
\text { fronder } 0\end{array}$ & $\begin{array}{l}(15 x) \text { OR } 011 \\
\{\text { zonder } 1 . \mathrm{E}\}\end{array}$ \\
\hline & & $\begin{array}{l}\text { (14x) OR012 } \\
\{\text { zonder } \mathbb{F}, 1\}\end{array}$ & $\begin{array}{l}(12 x) \text { OR024 } \\
\text { fander O, } 1, \mathbb{E}\end{array}$ & $\begin{array}{l}(23 x) \text { OR } 028 \\
\{\text { zonder } P, O, I, E\}\end{array}$ & \\
\hline \multirow[t]{4}{*}{5} & $16 / 255 x$ & $\begin{array}{l}(15 \mathrm{x}) \text { OR002 } \\
\text { (zorder } \mathrm{P} \text { ) }\end{array}$ & $\begin{array}{l}(14 x) O R 005 \\
\text { zander } F \text { ? }\end{array}$ & $\begin{array}{l}(17 x) \text { OR007 } \\
\text { izonder } \mathrm{P}, \mathrm{I}\end{array}$ & $\begin{array}{l}\text { (13x) Oroos } \\
\text { zonder } 1 \mathrm{E} \text { \} }\end{array}$ \\
\hline & & $\begin{array}{l}(13 x) \text { OR } 010 \\
\text { izonder } \mathrm{B}^{3} \mathrm{O}\end{array}$ & $\begin{array}{l}\text { (16x) OR014 } \\
\{\text { zonder F,E\} }\end{array}$ & $\begin{array}{l}(13 x) \text { OR015 } \\
\text { \{zonder } 0 . E\}\end{array}$ & $\begin{array}{l}(14 x) \text { OKO } 17 \\
\text { ander } P, 1,1\}\end{array}$ \\
\hline & & $\begin{array}{l}(20 x) \text { ORO19 } \\
\text { zonder } P, O, 1\end{array}$ & $\begin{array}{l}(19 x) O R 020 \\
\{\text { zonder } P, F, E\}\end{array}$ & $\begin{array}{l}(25 x) \text { OROQ } 1 \\
\{\text { zonder } P, O, E\}\end{array}$ & $\begin{array}{l}(12 \mathrm{x}, \mathrm{OR} 022 \\
\{z 0 n d \mathrm{der}, \mathrm{P}, \mathrm{O}\}\end{array}$ \\
\hline & & $\begin{array}{l}(15 x) \text { OR023 } \\
\left\{\text { zonder } F_{n} L E\right\}\end{array}$ & $\begin{array}{l}(15 x) \text { OR } 025 \\
\text { zzonder } F, O, 1\}\end{array}$ & $\begin{array}{l}\text { (20x) OR027 } \\
\{\text { zonder } P, F, 1, E\}\end{array}$ & $\begin{array}{l}(14 x) \text { ORO29 } \\
\text { zondar } P, F, O, 1\end{array}$ \\
\hline 6 & $7 / 121 x$ & $\begin{array}{l}(14 \mathrm{x}) \mathrm{OROO} \\
\{z \mathrm{ander} \mathrm{E}\}\end{array}$ & $\begin{array}{l}(13 x) \text { OR013 } \\
\text { tzonder } \mathrm{O}_{1} 1\end{array}$ & $\begin{array}{l}(23 \mathrm{x}) \text { ORO16 } \\
\{\text { zonder } F, O\}\end{array}$ & $\begin{array}{l}(20 x) \text { OROH } \\
\{\text { 2onder } P, F, 1\}\end{array}$ \\
\hline & 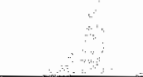 & $\begin{array}{l}(16 x) \text { ORO26 } \\
\text { (zonder } \mathrm{FO}, \mathrm{E})\end{array}$ & $\begin{array}{l}(19 x) \text { ORO } 30 \\
\text { zonder } P, F, \mathrm{O} \text { ) }\end{array}$ & $\begin{array}{l}\text { (16x) OR031 } \\
\text { (zonder } F, O, \mathbb{E}\}\end{array}$ & \\
\hline
\end{tabular}

Figuur 4. 12: Verdeling arintal gegeven verchillende wardeningen bij de 527 beoordelingen.

ringen. Je zou mogen verwachten een waardering voor OR001 (basismodel\} : uitstekend en voor OR032 zzonder P,F,O,I,E\}: zeer slecht.

Wanneer de gebruikte waarderingsmogelijkheden worden afgezet tegen de individuele casusstellingen blijkt dat:

- de waardering 'Goed' bij alle casusstellingen minimal door ến accountant is gegeven, een score van 100\%;

- de waardering 'Voldoende' met $96,9 \%$ bij één casusstelling ${ }^{16}$ niet is gegeven;

- de waardering 'Zeer Goed' met $93,8 \%$ bij een tweetal casusstellingen ${ }^{17}$ niet is gegeven;

- de waardering 'Onvoldoende' $84,4 \%$ bedroeg;

- de uiterste waarderingsmogelijkheden 'Zeer slecht' respectievelijk 'Uitstekend" maar ook 'Slecht' blijken met respectievelijk 3,1\%,59,4\% en $50 \%$ het minst gebruikt te zijn.

Slechts bij de drie casusstellingen komt de range van de drie waarderingen 'Zeer Goed', 'Goed' en 'Voldoende' niet voor ${ }^{18}$. Anderzijds betekent dit dat bij de overige 
29 andere casusstellingen, zijnde $90,62 \%$ van de gewaardeerde casusstellingen, de waarderingenrange 'Zeer Goed', 'Goed' en 'Voldoende" wel voorkomt. In het vorenstaande is alleen gekeken in hoeverre gebruik is gemaakt van de angeboden waarderingsmogelijkheden. Hierbij is geen onderscheid gemaakt in de frequentie waamee en warderingsmogelijkheid is gehanteerd. Hierop wordt later ingegaan.

Wanneer gekeken wordt naar de inhoudelijke kant van de gegeven oordelen, blijkt dat in $20 \%$ van de oordelen een wardering is gegeven met een negatieve inslag. Het betreft hier de waarderingen 'Onvoldoende' 15,2\%, 'Slecht' 4,6\% en 'Zeer slecht' $0,2 \%$. Van de overige $80 \%$ van de oordelen met een waardering met een positieve inslag blijkt $63,3 \%$ een wardering te hebben in de range 'Uitstekend" $7,4 \%$, "Zeer Goed' $23,5 \%$ en 'Goed' $32,4 \%$. In figum 4.13. is de verdeling van de gegeven warderingen grafisch weergegeven. De dominantie van de gebruikte waardering 'Goed' wordt zo duidelijk zichtbaar.

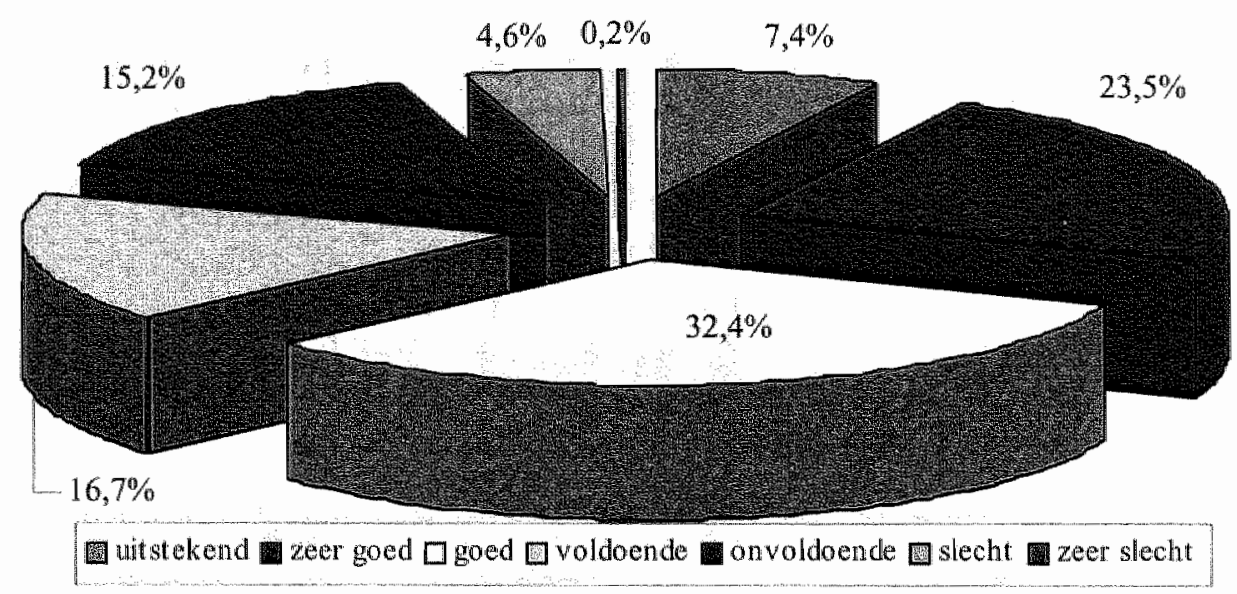

Figuur 4t 13: Frequentieverdeling gegeven waarderingen

In het hiervoorstande is angegeven dat bij 29 van de 32 casusstellingen, zijnde 90,62\%, de warderingrange 'Zeer Goed', 'Goed' en 'Voldoende' voorkomt. In deze reeks vallen 383 uitgevoerde beoordelingen, zijnde $72,7 \%$ van alle uitgevoerde beoordelingen.

Het oordeel 'Uitstekend' werd 39 keer gegeven verspreid over 19 verschillende casusstellingen, de waardering 'Zeer slecht' slechts één keer. De verdeling over de casusstellingen van deze uitersten ziet er als volgt uit: 


Oordeel
Cases
Oordelen

Figuar 4. 14: Castusstellingen met witerste oorded "Uiatekend" an 'Zeer slecht"

De volgende zaken zijn te constateren:

- naast de casusstelling OROO1 \{basismodel\} waarin alle beheersingsmaatregelen zijn opgenomen, hebben ook bijna alle casusstellingen waarin één beheersingsmaatregel ontbrak de waardering 'Uitstekend' gehad. In totaal betrof dit een vijftal casurstellingen met een 14-tal beoordelingen. De casusstelling warbij alleen de Organisatorische beheersingsmatregel (O) wiet was opgenomen heeft geen beoordeling gehad met een waardering van "Uitstekend";

- bij een zestal casusstellingen met een 13-tal beoordelingen werden twee van de vijf beheersingsmatregelen gemist;

- bij een vijftal casusstellingen met een 9-tal beoordelingen werden drie van de vijf beheersingsmatregelen gemist;

- bij een drietal casusstellingen met een 3-tal beoordelingen werden vier van de vijf beheersingsmatregelen gemist;

- slechts bij één beoordeling is de waardering 'Zeer slecht' gegeven. Ofschoon bij deze casusstelling drie van de vijf beheersingsmatregelen gemist werden kent deze casusstelling een vijftal verschillende waarderingen. De waarderingen die niet gegeven werden, zijn de waarderingen 'Uitstekend" en 'Slecht'.

- bij casusstellingen waarbinnen vier dan wel alle beheersingsmaatregelen ontbraken werd de wardering 'Zeer Slecht' niet aangetroffen.

Het vorenstaande is in figuur 4.15. grafisch weergegeven. Hieruit blijkt niet alleen dat de waarderingen 'Zeer Goed', "Goed" en 'Voldoende" bij bijna alle beoordelingen zijn gegeven. Ook de duidelijke dominantie van de gegeven warderingen 'Goed' en 'Zeer Goed' blijkt uit deze weergave gezien de dikte van de weergegeven lag. 


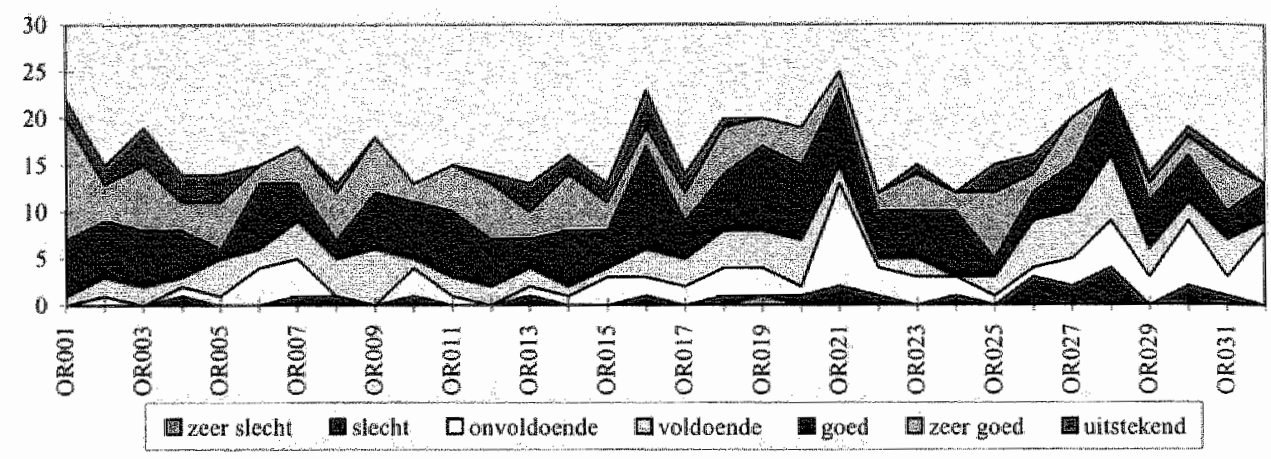

Pignur 4.15: Gegeven warderingen in antaller.

Om een indruk te krijgen van de betrokkenheid van de accountant bij het beoordelen van de casusstellingen is gekeken naar de beantwoording door accountants die meer dan één casusstelling hebben beoordeeld. Aangezien de te beoordelen casus-stellingen altijd verschillend waren mocht verwacht worden dat bij een grote mate van betrokkenheid van de accountant ook de wardering verschillend zou zijn. Het blijkt evenwel dat één accountant het vijftal aan hem voorgelegde verschillende casusstellingen met een waardering 'Zeer Goed' heeft gewaardeerd. De door deze accountant beoordeelde casusstellingen kennen een grote mate van verscheidenheid ten aanzien van het aantal opgenomen beheersingsmaatregelen. De invloed van deze ene accountant beloopt $0,95 \%$, hetgeen niet als een storende factor in de gegevensverzameling is beoordeeld.. Derhalve zijn deze gegevens niet geëlimineerd.

\subsubsection{Beoordelingswaarde per demografische invalshoek}

In bijlage 14: 'Overzicht gegeven waardeoordelen, diverse dwarsdoorsneden' is de frequentie van de gegeven waarderingen, bezien vanuit een vijftal verschillende invalshoeken, grafisch weergegeven. Deze invalshoeken zijn overeenkomstig de verzanelde demografische gegevens en hebben betrekking op het aantal kantoorwisselingen, het aantal ervaringsjaren, de leeftijd, de gevolgde opleiding en het aantal kantoorcollega's van de bij het onderzoek betrokken accountants. In figuur 4.16. is de procentuele verdeling weergegeven. Niet alle waamemingen zijn daarin weergegeven. Dit is gedaan omdat hetzij de gegevens niet bekend waren dan wel niet vergelijkbaar bleken met de rest van de selectie-indelingen.

Om vast te kunnen stellen of de waarderingen van de subselecties binnen de verschillende selecties afwijken van de totale waardering en in welke richting de waarderingen verschuiven, is een beoordelingswaarde berekend. Om deze berekening uit te kunnen voeren is aan de verschillende waarderingsmogelijkheden een gewicht (G) gegeven, startend met de waardering 'Zeer slecht' met gewicht 1 en oplopend tot 
Selecties $\mathrm{B}$, Waarderingsmogelikheden (n)

witste- zeer 4 goed fol 4 onvol slech zeer

kend , goed a doende doende 3 slecht

Aantal kantoorwisselingen, 527 waarnemingen; $100 \%$

$\begin{array}{lcccccccc}\text { eerste kantoor } & 169 & 3,55 \% & 30,18 \% & 28,40 \% & 15,98 \% & 15,38 \% & 6,51 \% & 0,00 \% \\ 1 \text { 1mal } & 122 & 11,48 \% & 18,85 \% & 35,25 \% & 16,39 \% & 12,30 \% & 4,92 \% & 0,82 \% \\ 2 \text { m } 3 \text { mal } & 135 & 7,41 \% & 28,89 \% & 27,41 \% & 18,52 \% & 14,81 \% & 2,96 \% & 0,00 \% \\ >3 \text { mal } & 101 & 8,91 \% & 10,89 \% & 42,57 \% & 15,84 \% & 15,84 \% & 5,94 \% & 0,00 \%\end{array}$

Ervaringsjaren, 527 waarnemingen; 100\%

$\begin{array}{lclllllll}0-9 \text { jaar } & 127 & 3,15 \% & 23,62 \% & 28,35 \% & 18,11 \% & 22,05 \% & 4,72 \% & 0,00 \% \\ 10-19 \text { jaar } & 234 & 9,83 \% & 23,50 \% & 30,34 \% & 17,52 \% & 14,10 \% & 4,27 \% & 0,43 \% \\ 20-29 \text { jaar } & 117 & 7,69 \% & 22,22 \% & 38,46 \% & 14,53 \% & 12,82 \% & 4,27 \% & 0,00 \% \\ 30-50 \text { jaar } & 49 & 6,12 \% & 26,53 \% & 38,78 \% & 14,29 \% & 8,16 \% & 6,12 \% & 0,00 \%\end{array}$

Leeftijden, 527 waarnemingen; $100 \%$

$\begin{array}{rrrrrrrrr}25-29 \text { jar } & 39 & 2,57 \% & 25,64 \% & 20,51 \% & 20,51 \% & 23,08 \% & 7,69 \% & 0,00 \% \\ 30-39 \text { jaar } & 262 & 7,25 \% & 24,43 \% & 30,91 \% & 16,03 \% & 17,18 \% & 3,82 \% & 0,38 \% \\ 40-49 \text { jaar } & 166 & 10,84 \% & 22,29 \% & 32,53 \% & 17,47 \% & 12,05 \% & 4,82 \% & 0,00 \% \\ 50-77 \text { jaar } & 60 & 1,67 \% & 21,67 \% & 46,66 \% & 15,00 \% & 10,00 \% & 5,00 \% & 0,00 \%\end{array}$

Gevolgde opleiding, 525 waarnenningen; $99,62 \%$

$\begin{array}{lrrrrrrrr}\text { Uniwersitaire } & 226 & 4,42 \% & 22,12 \% & 33,63 \% & 18,14 \% & 15,93 \% & 5,75 \% & 0,00 \% \\ \text { NIVRA } & 299 & 9,70 \% & 24,75 \% & 31,44 \% & 15,38 \% & 14,72 \% & 3,68 \% & 0,33 \%\end{array}$

overige $\quad 2$

Aantal kantoorcollega"s, 522 waarnemingen; $99,05 \%$

\begin{tabular}{|c|c|c|c|c|c|c|c|c|}
\hline tot $<11$ & 184 & $5,43 \%$ & $17,39 \%$ & $36,96 \%$ & $19,57 \%$ & $18,48 \%$ & $2,17 \%$ & $0,00 \%$ \\
\hline $\operatorname{tat} 11-100$ & 151 & $8,61 \%$ & $29,80 \%$ & $27,15 \%$ & $13,91 \%$ & $15,23 \%$ & $4,64 \%$ & $0,66 \%$ \\
\hline tot $>100$ & 187 & $8,56 \%$ & $24,60 \%$ & $31,55 \%$ & $16,04 \%$ & $12,30 \%$ & $6,95 \%$ & $0.00 \%$ \\
\hline onbekend & 5 & & & & & & & \\
\hline
\end{tabular}

Totaal, 527 waarnemingen; $100 \%$

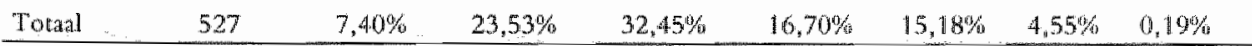

Figun 4.16: Frequentieverdeling gegeven warderingen per denografsche invalshoek 
de wardering 'Uitstekend' met het gewicht 7. De beoordelingswarde van een subselectie wordt als volgt berekend:

$$
B W=\frac{\left.\sum_{n=m}^{\operatorname{singm}(B w m \times \mathrm{C} w m}\right)}{B}
$$

warabij geldt:

- $\mathrm{BW}=$ beoordelingswaarde;

- wm = warderingsmogelijkheid;

- $\mathrm{B}=$ aantal beoordelingen;

- Gwm = gewicht per warderingsmogelijkheid.

Vervolgens is de procentuele afwijking ten opzichte van de totale beoordelingswaarde bepaald. Deze totale beoordelingswarde kan liggen tussen het getal 1 en $7^{19}$. De totale beoordelingswaarde komt uit op 4,7686. Een positieve afwijking in de beoordelingswaarde van een selectie ten opzichte van de totale beoordelingwaarde duidt op een over het geheel genomen positievere waardering binnen de selectie ten opzichte van totale beoordelingen. Deze informatie is in figuur 4.17. weergegeven.

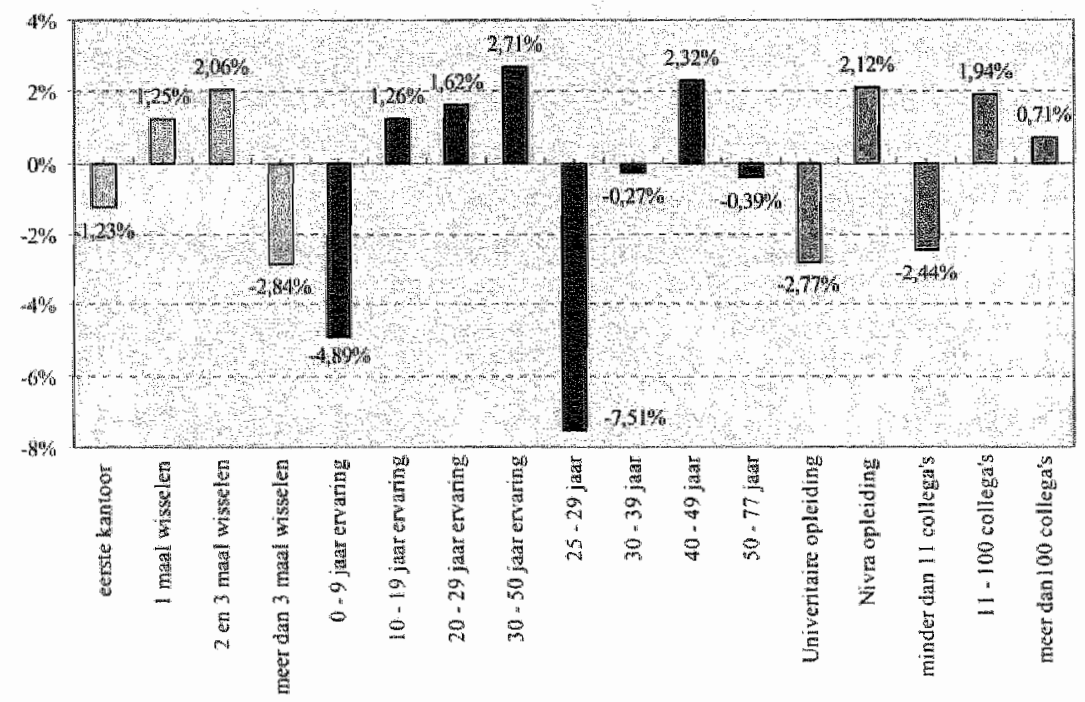

Figuur 4.17: Procentucle affwijking beoordelings waarde ten opzichte van totale beoordelingswaarde

De procentuele afwijkingen van de beoordelingswaarden van de verschillende selecties ten opzichte van de totale beoordelingswaarde variëren van $+2,71 \%$ voor de selectie ervaring $30-50$ jaar $^{20}$ tot $-7,51 \%$ voor de selectie leeftijd $25-29$ jaar $^{21}$. 
Hierbij dient te worden opgemerkt dat deze twee selecties tot de kleinste in omvang behoren. De selectie ervaring $30-50$ jaar omvat slechts $9,3 \%$ van de beoordelingen, de selectie leeftijd $25-29$ slechts $7,4 \%$ van de beoordelingen.

Uit de procentuele afwijking van de beoordelingswaarde per selectie zijn voorts de volgende observaties te maken:

- de afwijkingen van de beoordelingswaarden van de verschillende selecties ten opzichte van de beoordelingswaarde van het totaal ligt tussen de $-7,51 \%$ en de $+2,71 \%$

- een positieve verschuiving is waar te nemen naarmate vaker gewisseld wordt van kantoor tot en met drie maal wisselen. Het betrof hier $80,8 \%$ van de beoordelingen. Indien meer dan drie keer van kantoor is gewisseld wordt de positieve verschuiving omgebogen;

- een toename van ervaring laat een positieve verschuiving in de beoordelingswaarde zien;

- een toename van de leeftijd tot en met 49 jaar laat een positieve verschuiving in de beoordelingswaarde zien. Het betrof hier $88,6 \%$ van de beoordelingen. Vanaf 50 jaar wordt de positieve verschuiving omgebogen;

- accountants met een NIVRA-opleiding waarderen positiever dan de accountants met een universitaire opleiding;

- een positieve verschuiving is waar te nemen naarmate de kantoren groter worden tot en met 100 collega's. Het betrof hier $64,18 \%$ van de beoordelingen. Indien meer dan 100 collega's op een kantoor aanwezig zijn wordt de positieve verschuiving omgebogen.

\subsubsection{Beoordelingswaarde per aantal soorten beheersingsmatregelen}

Zoals in paragraaf 4.4.4. is aangegeven zijn de casusstellingen gegroepeerd in een zestal groepen. Deze groepen worden gevormd door het aantal soorten beheersingsmaatregelen dat in de casusstellingen is opgenomen ${ }^{22}$, variërend van 0 tot en met 5 soorten beheersingsmaatregelen. In figuur 4.18. is het aantal gegeven waardeoordelen opgenomen conform bovengenoemde indeling en zoals opgenomen in figuur 4.10.

Om vast te kunnen stellen of de waarderingen binnen de selecties afwijken van de totale waardering en in welke richting deze waarderingen verschuiven, is voor iedere selectie de beoordelingswarde berekend en weergegeven in figuur $4.19^{23}$.

Indien gekeken wordt naar de beoordelingswaarden bij de verschillende subselecties van casusstellingen met een verschillend aantal soorten beheersingsmaatregelen, komt een negatieve tendens naar voren. In figuur 4.20. zijn de procentuele afwij- 


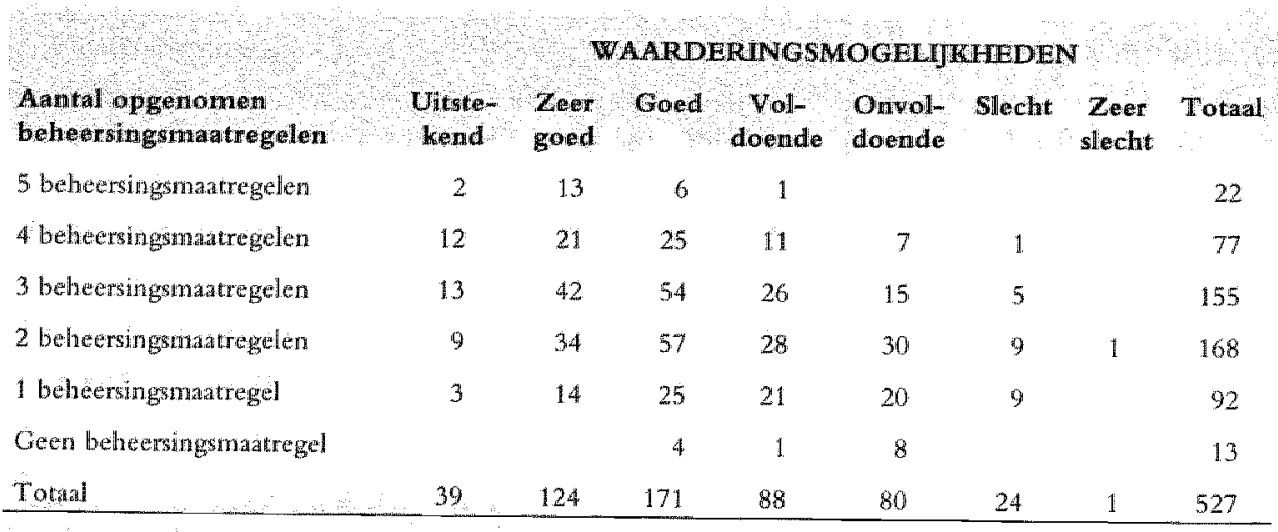

Figutur 4.18: Spreiding watrdeoordelen over casusstellingen met verschillend aantal soorten befheersingsmaatrem gelen

\begin{tabular}{lr} 
Aantal opgenomen beheorsingsmatregelen & Beoord \\
5 beheersingsmaatregelen & 5,7273 \\
4 beheersingsmatregelen & 5,2208 \\
3 beheersingsmatregelen & 4,9806 \\
2 beheersingsmaatregelen & 4,6012 \\
11 beheersingsmaatregel & 4,2609 \\
Geen beheersingsmaatregelen & 3,6923 \\
Total & 4,7685 \\
\hline
\end{tabular}

Figutur 4.19: Beoordelingswarden in total

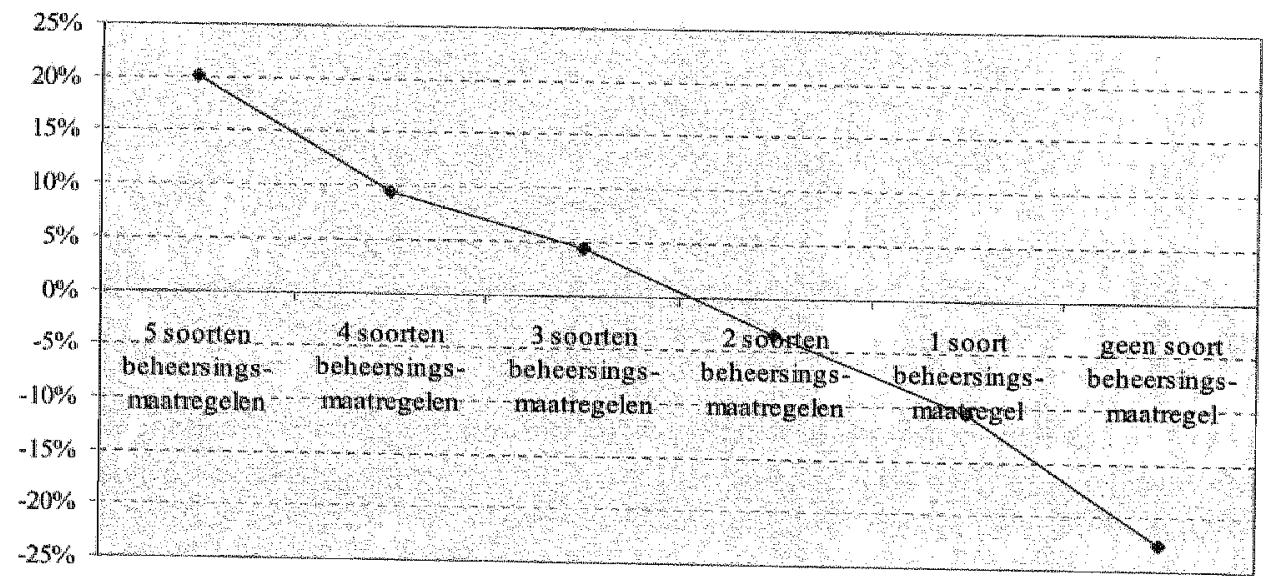

Figuru 4,20: Procentaele vatloop beoordelingswarden in total 
kingen van de beoordelingswaarden gevisualiseerd voor de subselecties en afgezet tegen de beoordelingswaarde van het totaal aan gegeven antwoorden. De negatieve tendens wordt hierbij duidelijk zichtbaar en varieert ten opzichte van de beoordelingswaarde van het total aan gegeven antwoorden van $+20,11 \%$, voor de groep met alle vijf de beheersingsmaatregelen tot $-22,57 \%$ voor de groep zonder enig beheersingsmaatregel.

Met behulp van de Spearman correlatiecoëfficiënt is nagegaann en bevestigd dat een relatie bestaat tussen de gegeven beoordelingen en het aantal soorten beheersmaatregelen. De Spearman correlatiecoëfficiënt werd berekend op $0,303 \mathrm{en}$ als significant bepaald op .01 level (1-tailed).

\subsubsection{Samenvatting beoordeling casusstellingen}

Bij de gegeven beoordelingen van de casusstellingen is een grote mate van spreiding te constateren. Van de maximaal ter beschikking staande 224 waarderingsmogelijkheden werd $69,6 \%$, (156 mogelijkheden) gebruikt. Minimaal drie en maximaal zes van de zeven verschillende waarderingsmogelijkheden werden aan de casusstellingen gegeven. $\mathrm{Bij} 71,9 \%$ van de casusstellingen werden vijf of zes verschillende warderingen gegeven; dit betrof $71.4 \%$ van alle uitgevoerde beoordelingen ${ }^{24}$.

Bij 29 van de 32 casusstellingen werd een waarderingsreeks van 'Zeer Goed', 'Goed' en 'Voldoende' gegeven. De waardering 'Goed' werd aan alle casusstellingen minimaal één keer gegeven. In 80\% van de beoordelingen werd een waardering gegeven met een positieve strekking. Van de overige $20 \%$ van de beoordelingen met een waardering met negatieve strekking werd in $76 \%$ de waardering 'Onvoldoende' gegeven. De uiterste waardering 'Uitstekend' werd bij 39 beoordelingen gegeven, de andere uiterste waardering 'Zeer slecht' slechts bij één beoordeling.

Uit de berekende beoordelingswaarde kan geconstateerd worden dat naar mate meer ervaring wordt opgedaan een positiever waardeoordeel wordt gegeven aan de beoordeelde casusstellingen. Het antal kantoorwisselingen en de leeftijd van de beoordelende accountant lijken dit te bevestigen. Voorts waarderen accountants met een NIVRA-opleiding positiever dan accountants met een universitaire opleiding. Ook naar mate een kantoor groter wordt, met uitzondering van kantoren groter dan 100 kantoorcollega's, leidt dit tot een positievere waardering. Tevens blijkt uit de berekende beoordelingswaarden dat een afname van het aantal soorten beheersingsmaatregelen de door de accountants gegeven waarcleoordelen negatief beinvloedt, welke beïnvloeding als significant beoordeeld kan worden. 


\subsection{Samenvatting}

In het vorenstaand hoofdstuk is nader ingegaan op de typologie van het onderzoek en de onderzoeksinstrumenten. Bij de bepaling van het type onderzoek is aangesloten bij de typologie van onderzoeken zoals die is ontwikkeld in de sociale en gedragswetenschappen [De Groot, 1994, 1961]. Het onderhavige onderzoek is getypeerd als een comparatief survey onderzoek met een verklarende onderzoeksgrondvorm.

Als selectiecriteria voor de onderzoekspopulatie hebben gegolden het als openbaar accountant werkzaam zijn in Nederland en ingeschreven zijn in het register van het Koninklijk NIVRA. Op basis van deze criteria werd van het Koninklijk NIVRA een lijst ontvangen met 3928 namen waarvan $20 \%$ aangezocht is om aan het onderzoek deel te nemen.

Bij het onderzoek is een drietal verschillende onderzoeksinstrumenten gehanteerd, te weten: vragenlijsten, casusstellingen en psychologische tests. De vragenlijsten en de casusstellingen zijn specifiek voor dit onderzoek ontworpen, de psychologische tests zijn reeds jarenlang in gebruik. De vragenlijsten waren zodanig opgezet dat in het merendeel van de gevallen keuzes gemaakt dienden te worden uit vooraf gedefinieerde antwoorden.

De accountants die uiteindelijk betrokken zijn bij het onderzoek hebben een aantal casusstellingen, betrekking hebbende op het administratief-organisatorisch proces van personeelszaken, beoordeeld. Deze beoordeling was gericht op de toereikendheid van de beheersing van dit proces. Hierbij diende door de accountants alleen een waarderingsaanduiding aangekruist te worden op een zevenpuntsschaal. Een motivering van de gemaakte keuze kon op een bijgevoegd blad worden gegeven maar werd niet gevraagd.

Door het samennemen van verschillende procesactiviteiten op basis van gemeenschappelijke beheersingsmaatregelen is op een gecontroleerde manier een totale set van tweeèndertig verschillende casusstellingen ontwikkeld welke aan de accountants zijin voorgelegd.

Tevens hebben de bij het onderzoek betrokken accountants een tweetal psychologische tests afgelegd, de ene ter meting van de cognitieve stijl, de Myers-Briggs Type Indicator, de andere als meting van de tolerantie voor ambiguiteit, de AT-20 Scale van MacDonald.

Bij de ontwikkeling van de casusstellingen, is gebruik gemakt van een flowcharttechniek ondersteund door het geautomatiseerde pakket System Development Workbench. De bij het onderzoek verzamelde onderzoeksgegevens zijn vastgelegd in een relationele database van Oracle met behulp van een user interface van Micro- 
soft Access en verwerkt, voor zover noodzakelijk, met behulp van het statistische pakket SPSS.

In totaal hebben 199 accountants, verspreid over 61 verschillende vestigingsplaatsen en voor $63 \%$ werkzaam binnen een kantoor met minder dan 100 andere accountants, hun medewerking aan het onderzoek verleend. In totaal werden 527 casusstellingen beoordeeld.

Uit de berekening van de beoordelingswaarde blijkt dat naarmate de ervaring toeneemt tot een positiever waardeoordeel gekomen wordt. Daamaast blijkt dat accountants met een NIVRA-opleiding tot een positiever waardeoordeel komen dan accountants met een universitaire opleiding en dat accountants verbonden aan een groter kantoor eveneens tot een positiever waardeoordeel komen dan hun collega's verbonden aan kleinere kantoren. Tevens blijkt uit de berekening van de beoordelingswaarde dat naar mate minder beheersingsmaatregelen opgenomen zijn in de casusstelling door de beoordelende accountant een lagere waardering is gegeven, welke relatie met behulp van de Spearnan correlatiecoëfficiënt als significant is vastgesteld.

Uit de grote spreiding in de gegeven oordelen blijkt geen eensluidende waardering bij de beoordeling van de verschillende casusstellingen. Gekeken is alleen naar het voorkomen van een bepaalde waardering en niet of deze waardering een meerderheidsstandpunt van de beoordelende accountants vertegenwoordigt. Derhalve kan deze conclusie niet worden geinterpreteerd als zijnde het ontbreken van 'consensus' in de beoordeling door accountants overeenkomstig de stelling van Meservy, Bailey en Johnson [1986]. Dit laat onverlet dat deze conclusie een bijdrage zal leveren aan het uiteindelijk beantwoorden van de eerste vraagstelling.

\section{Noten}

1 V1: Komen accountants bij de beoordeling van gelijke adninistrachorganisatorische processen tot gelijkluidande oordelen?

V2. Is de voorkeur wan de acconntans voor bepald soort beheesingsmatregel wan inwoed op de gegeven wardeoordellen en de consensus in de oordelen?

V3: Wijkt het psychologische profiel vande accountants die meegewerkt hebben an deze studie af van dat van accountonts die hebben meegewerkt aan andere soorgelike studies?

2 De mailings vonden plats op 17 juni 1997, 300 accountants; 25 juni 1997, 157 accountants; 28 julli 1997,293 accountants th op 25 augustus 1997,3 . accountants.

3 De gegevens zijn wastgelegd in de relationele database Oracle 7 release 7.3 . Ten behoeve van de invoer wan de basisgegevens alsme de voor het exporteren wangegevens werd als 'user interface' gebruikgemaakt van dawroor beschikbare onderdelen wan Microsof Access, release 7.0. De statistische analyse van de veramelde gegewens. heeft voorts platsgewonden met behulp wan het statistische pakket SPSS.

4 Het Personelszakenproces is grekozen omdat de accountant bijna bij iedere controle wan de jaartekening ibx de een of andere worm geconfrontexd word met dit proces. Alleen in die gevalle waxtin binten de te controle ren ondemenung geen werknenzers aanwezig zijn zal hij dit proces niet tegenkomen. Damarnast zijn binnern het Parsonedszakenproces alle administratieforganisatorische functies te onderkenanen alsmede te ondernemen acties 
en behersingsmatregelen. Derhalve mag bekendheid wan de accountant met het Perronelszakenproces verwacht worden.

5 De aanzet rot het nemert wath proces gevich op personedszaken is gegewen door de onderzoeken van Ashton en Brown [1980], Ashton en Kramer [1980], Ahhon [1977] en Ashton [1974a, 1974b],

6 Onder logische toegangsbeveliging wordr verstan de functiescheiding zoals die in het geautomatiseerde systeem is ondergebracht. De functioscheiding in bet handmatige gedeelte wan het personeelszakenproces en log sche tocgangibeveiliging is én op elkatr afgestemc gehee.

7 Onder formele controle wor to verstan huet vaststellen dat het object van controle voldoet an alle daanara te stellen fomele eisen vastgeltegd in tegel geving zowel birnen als buten de organisatie vastgesteld

8 Onder materiele controle wordt verstan het vaststellen dai het objecr van controle voldoet aan alle danaan te steillen inhoudelijke essen, kwantatief en kwalitatiof $f_{x}$

9. Het basismodel is opgenomen in bijlage 7: "Personeelizakenproces, de casustelling'

10 Voorde castussellingen wordt de wolgende amnotate gehanteed: ORO Oxx missende beheersingsmatregelen\}, wataj OL stat woor Organisatorische Representatie. De missende beheersingmatregel worden daabij met de volgerde letters angeduid:

- $P=$ Proces beheersingsmatregel;

- F Financied beheersingsinatregel;

- $O=$ Onganisarorisch beheersingsinatrege];

- I 2 Informatie beheersingsmatregel;

- $\mathbb{E}=$ Prescatie beheersingsmatregel.

fen annotatie van ORO 10 \{zonder $\mathrm{P}_{\text {}} \mathrm{O}$ \} impliceert dat in deze casusstelling geen beheersingmatregelen zujn opgenomen op het gebied wan de Processen en de Organisatie. In het basismodel zijn alle beheersingsmatregelen anwezighengeen aangegeven is in de annotatie ORO01 (basismodely.

11. Voot een nadere uiteenzetting van de verchillende sooten kennis wordt werwezen nar paragrafen 2.3.3. De variabele "Kennis".

12 Hienvor wordt werwezen naar paragraf 2,31. De wariabele 'Ervaring'.

13 Het betrof ther de casusstellingen OR022 zonder P, F, O\} en ORO24 zonder O,I,E\}

14 Het betrof hier de casusstelling OR02\| zonder $\mathrm{P}, \mathrm{O}, \mathrm{E}\}$.

15 Te weten 32 casusstellingen ieder met 7 warderingsrnogelijkheden.

16 Dit betreft de castustelling OR 024 zzonder O,I,E).

17 Dit betreffen de casusstellingen OR028 (zonder P,O,I,E\} en OR032 \{zonder P,F,O, I,E\}.

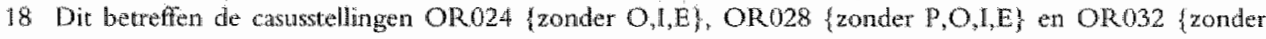
$P, \mathrm{P}_{1}, \mathrm{~L}, \mathrm{E}$.

19 De beoordelingswarde 1 wordt verkregen indien in een selectie alleen dle waardering 'Zeer slecht' is gegeven. De beoordwlingswarde 7 wordt werkregen indien alleen de watrdering "Uitstekend" is gegeven.

20 Beocrdelingswande woor de selectie orwaring $30-50$ jaar bedragt 4,8980 .

21 Beoordelingwarde voor de selectie leeftijd $25-29$ jar bedragt 4,4104 .

22 Een total overzicht wan de wardaringe is opgenomen in bijlage 14: 'Overzicht gegeven wardeoordelen en consenstswarden"

23 De volledige lijst met gegeven waluderingen is opgenomen in bijlage: 16: "Verdeling wardeoordelen per ervaringrangen en beoondelingswarden'.

24. Her betroffen 23 van de 32 castussellingen en 376 van de 527 nitgevoerde beoordelingen. 


\section{Resultaten}

\subsection{Inleiding}

In het voorgaande zijn de internationale en nationale ontwikkelingen binnen het accountantsberoep geschetst voor zover deze betrekking hebben op het kennisdomein Administratieve Organisatie en is, op basis van een theoretische beschouwing, een drietal onderzoeksvragen opgesteld en een zevental hypotheses ontwikkeld. Vervolgens is ingegaan op de gevolgde onderzoeksopzet en de onderzoeksinstrumenten. Hoofdstuk 4 is afgesloten met een algemene beschouwing over de respons van de aan het onderzoek meewerkende accountants op de vragenlijsten, psychologische tests en casusstellingen.

Dit vijfde hoofdstuk bevat de bevindingen van de analyses die zijn uitgevoerd op de informatie uit de ingevalde vragenlijsten, de uitkomsten van de psychologische tests en de antwoorden op de casusstellingen. Op basis van deze analyses worden conclusies getrokken ten aanzien van het al dan niet verwerpen van de geformuleerde hypotheses.

Overeenkomstig de hypotheses zijn de analyses gegroepeerd naar de drie onderzoeksvragen:

1. de 'consensus' tussen de oordelen van de accountants; als een proxy voor professional judgment;

2. de 'voorkeur' van de accountant; als een proxy voor het soort beheersingsmaatregel dat de grootste bijdrage levert aan het prototypisch mentaal model gericht op de beoordeling van administratief-organisatorische processen;

3. weranderingen van het psychologische profiel van de accountant.

In hoofdstuk 6 wordt de koppeling gelegd tussen de conclusies van de hypotheses en de drie onderzoeksvragen. Daarbij wordt per onderzoeksvraag een anzet gegeven voor het vervolgonderzoek. 


\subsection{Consensus tussen oordelen van accountants}

Deze paragraaf bevat de observaties, bevindingen en conclusies die betrekking hebben op de eerste onderzoekswraag. Zoals gesteld in hoofdstuk 1 betreft de eerste onderzoeksvraag het evaluatiecriterium 'consensus' volgens het framework van Solomon en Shields [1995] en het framework van Ashton [1983]. Om deze vraagstelling te kunnen beantwoorden zijn in hoofdstuk 3 een vijftal hypotheses geformuleerd. Onder 'consensus' wordt in deze studie de invulling gehanteerd uit het framework van Solomon en Shields [1995]: 'het niveau van gegeven gelijkluidende oordelen'.

Door het grote aantal verschillende beheersingsmaatregelen en het grote veelvoud van mogelijkheden waarin deze beheersingsmaatregelen onderling kunnen samenwerken is het niet mogelijk om te spreken van een unieke set van maatregelen die samen een normatief model vormen [Mouthaan, 2001, 2000; Meservy, Bailey en Johnson, 1986]. Meservy, Bailey en Johnson [1986] stellen dat het gemis aan een normatief model gecompenseerd moet worden door als uitgangspunt te nemen: de consensus in de oordelen van accountants in concrete situaties welke zijn opgenomen in paragraf 5.2.3.1.

Bij het inzichtelijk maken van de consensus in de oordelen van de accountants aangaande het Personeelszakenproces is onder meer gebruik gemaakt van:

- de variantieanalyses One-Way ANOVA en 'post-hoc'-vergelijkingen en, indien noodzakelijk, de Kruskal-Wallis toets en de Levene's test for equality of variance om vast te stellen in hoeverre sprake is van significante verschillen in de gegeven oordelen binnen de selecties ${ }^{1}$

- een beoordelingswaarde en de Spearman's correlatiecoëfficiënt on na te gaan in hoeverre verschuivingen in de waarderingen plaatsvinden binnen een selectie.

Zoals eerder is aangegeven. [Mouthaan, 2001, 2000; Meservy, Bailey en Johnson, 1986], kan een normatief model van een set met beheersingsmaatregelen alleen worden opgezet vanuit de beoordelingen door de accountants in de praktijk. Daardoor kan geen rangorde worden aangegeven in de verschillende sets met beheersingsmaatregelen. Bij de statistische analyse kon hierdoor niet rechtstreeks gebruik worden gemaakt van de beoordeelde casusstellingen. Door de beoordeelde casusstellingen te groeperen naar het aantal daarin voorkomende soorten beheersingsmaatregelen kon wel een rangorde worden geformeerd. Bijlage 8: 'Overzicht casusstellingen met aanwezige beheersingsmaatregelen' geeft weer welke soorten beheersingsmaatregelen zijn opgenomen in welke casusstellingen. De vraagstelling over de wardering van de casusstellingen is verankerd, waardoor de afstanden tussen 
de antwoorden als gelijk zijn te interpreteren. Doordat bij de meting een semantische differentiaal wordt gebruikt, zijn deze afstanden als intervaldata te beschouwen.

In hoofdstuk 3 is aangegeven dat het geheel van de mix van beheersingsmaatregelen bepalend is of al dan niet sprake is van een toereikend geheel van beheersingsmaatregelen. Onderlinge substitutionaliteit van beheersingsmaatregelen is daarbij mogelijk. Dit was met name gebaseerd op de afwezigheid van een eenduidige normstelling, de andacht die tijdens de opleiding aan de vijf soorten beheersingsmatregelen wordt gegeven en de opbouw van prototypische mentale modellen wartegen de werkelijkheid wordt afgezet.

De resultaten zijn in deze paragraaf als volgt rondom de vijf hypotheses gegroepeerd:

- Consensus in oordeel, algemeen

- Consensus in oordeel, per aantal jaren werkervaring

- Consensus in oordeel, per aantal soorten beheersingsmaatregelen

- Consensus in oordeel, per belangrijkheid van soort beheersingsmaatregel

- Consensus in oordeel, per cognitieve stijl

Bij de behandeling van de resultaten per hypothese wordt gestart met de in hoofdstuk 3 geformuleerde hypothese. Deze paragraaf wordt afgesloten met een korte samenvatting van de resultaten.

\subsubsection{Consensus in oordeel, algemeen}

Bij het formuleren van de eerste hypothese in hoofdstuk 3 werd een zekere mate van standaardisatie binnen het vakgebied verondersteld. Dit was gebaseerd op nationale en internationale maatschappelijke ontwikkelingen aangaande de beheersing van administratieve processen, in Nederland nog eens versterkt door een verplicht centraal landelijk examen van het vakgebied Administratieve Organisatie. De eerste hypothese was als volgt geformuleerd:

H1: Tussen de oordelen van accountants aangaande de toereikendheid wan administratieforganisatorische processen bestad consensus.

In paragraaf 4.4.4 is ingegaan op de spreiding van de door de accountants gegeven oordelen. De zeer hoge waarden die de waarderingen 'Voldoende' met 96,9\%, 'Goed" met 100\% en 'Zeer Goed' met $93,8 \%$ hebben gekregen, doen vermoeden dat de beoordelaars weinig verschillen hebben onderkend tussen de verschillende casusstellingen. Dit hoeft niet zo te zijn. In het vorige hoofdstuk is alleen gekeken of een bepaald oordeel door minimaal één accountant bij de beoordeling van een casusstel- 
ling is gegeven. De vraag die nu naar voren komt is: in hoeverre is een gegeven oordeel over een casusstelling de mening van één accountant, danwel van meerdere accountants die een beoordeling van diezelfde casusstelling hebben uitgevoerd?

Om inzicht te verkrijgen in 'het niveau van gegeven gelijkluidende oordelen', ofwel de "consensus" van de beoordelaars bij de beoordeling van de verschillende casusstellingen, wordt per beoordeelde casusstelling een consensuswaarde berekend. Ook worden twee consensusindices bepaald, één gericht op de casusstellingen en één gericht op de beoordelingen. De betekenis hiervan is als volgt:

- De 'consensuswaarde' geeft weer de procentuele verdeling van de door de accountants gegeven waarderingen van een casusstelling. Aangezien door de beoordelende accountants steeds verschillende casusstellingen zijn beoordeeld geeft dit percentage tevens weer het percentage van beoordelende accountants die eenzelfde waardering hebben gegeven aan een casusstelling.

- De 'consensusindex gericht op casusstellingen' geeft het percentage casusstellingen weer die een consensuswaarde scoren op één van de zeven waarderingsmogelijkheden welke groter dan wel gelijk is aan een vooraf ingesteld consensus meetpunt.

- De 'consensusindex gericht op beoordelingen' geeft het percentage beoordelingen weer die een consensuswarde scoren op één van de zeven waarderingsmogelijkheden welke groter dan wel gelijk is aan een vooraf ingesteld consensus meetpunt.

- Het Consensus Meetpunt is een flexibel in te stellen percentage.

In bijlage 13: 'Overzicht gegeven waardeoordelen en consensuswaarden' zijn de uitkomsten weergegeven van de consensuswaarden-berekening voor alle casusstellingen. Voor iedere casusstelling is een hoogste consensuswaarde berekend, die daarbij altijd gekoppeld is aan éen van de waarderingsmogelijkheden. In de tabel in figuur 5.1 zijn deze hoogste consensuswaarden per waarderingsmogelijkheid samengevat. Bij 6 casusstellingen werden meerdere aan elkaar gelijke hoogste consensuswaarden berekend. Daardoor ontstonden 111 dubbeltellingen en werden voor de 32 casusstellingen in total 43 hoogste consensuswaarden bepaald ${ }^{2}$. De hoogste consensuswarde varieerde van $23,1 \%$ tot en met $61,5 \%$.

Op basis van de berekening van de consensuswaarden, zoals weergegeven in bijlage 13: 'Overzicht gegeven waardeoordelen en consensuswaarden', valt de grote spreiding van de gegeven beoordelingen op. Uit figuur 5.1 valt op dat de hoogste consensuswaarden voor $76,8 \%$ gemeten werden bij de waarderingsmogelijkheden 'Zeer goed" (27,9\%) en 'Goed' (48,9\%). De waarderingsmogelijkheid 'Goed' heeft bij 21 van de 32 casusstellingen het predikat hoogste consensuswaarde gekregen, zijnde 


\begin{tabular}{lccc} 
Waarderingsmogelijklieden & Casus & Hoogste consensuswarde & $\%$ \\
Uitrickend & 1 & $23,1 \%$ & $2,3 \%$ \\
Zeer goed & 12 & $23,1 \%-59,1 \%$ & $27,9 \%$ \\
Goed & 21 & $23,1 \%-58,3 \%$ & $48,9 \%$ \\
Voldoende & 5 & $23,5 \%-33,4 \%$ & $11,6 \%$ \\
Onvoldoende & 4 & $23,5 \%-61,5 \%$ & $9,3 \%$ \\
Slechr & 0 & & $0,0 \%$ \\
Zeer slecht & 0 & & $0,0 \%$ \\
Toral & 43 & & $100,0 \%$ \\
\hline
\end{tabular}

Figuur 5.1: Hoogste consensuswaarden

$65,6 \%$. Wanneer gekeken wordt naar de waarderingsmogelijkheden 'Zeer Goed' en 'Goed' wordt de in het vorige hoofdstuk gememoreerde dominantie in de waarderingen bevestigd. $\mathrm{Bij} 28$ van de 32 casusstellingen, zijnde $87,5 \%$, blijkt één van deze twee waarderingen te behoren tot de hoogste consensuswaarde ${ }^{3}$.

Indien het Consensus Meetpunt $(\mathrm{cm})$ wordt gesteld op minimaal $50 \%$ bedraagt de consensusindex:

- grericht op de casusstellingen (CI(c,50\%)): 9,38\%

- gericht op de beoordelingen $(\mathrm{CI}(\mathrm{b}, 50 \%)): 5,31 \%{ }^{5}$.

Dit impliceert dat slechts in $9,38 \%$ van alle 32 casusstellingen - waarbij $5,31 \%$ van alle 527 beoordelingen zijn betrokken - een gelijkluidende waardering is gegeven door minimaal $50 \%$ van de beoordelende accountants van die betreffende casusstelling. Deze $9,38 \%$ vertegenwoordigt een drietal casusstellingen. Twee daarvan betroffen de zogenaamde uiterste casusstellingen, te weten OR001 \{basismodel\} met daarin alle beheersingsmaatregelen en OR032 zonder $\mathrm{P}, \mathrm{F}, \mathrm{O}, \mathrm{I}, \mathrm{E}\}$ met daarin niet één beheersingsmaatregel. Bij de derde casusstelling OR024 \{zonder $\mathrm{O}, \mathrm{I}, \mathrm{P}\}$ ontbraken drie beheersingsmaatregelen.

Figuur 5.2 geeft de procentuele verdeling van de consensuswaarde per casusstelling weer. De dominantie van de waarderingen 'Zeer Goed' en 'Goed' komt tot uitdrukking in de dikte van de weergegeven balk. In figuur 5.2 is de relatieve verdeling weergegeven van de beoordelingen zoals deze blijkt uit figuur 4.15 .

De consensusindices van een selectie geven inzicht in de mate van consensus binnen een selectie. In figuur 5.3 zijn de twee consensusindices opgenomen van de dwarsdoorsneden uit paragraaf 4.4.4.2, voor zover deze minimaal gelijk zijn aan $50 \%$. Opgemerkt wordt dat naarmate het in een selectie opgenomen aantal beoordelingen kleiner wordt, dit een verstorende factor kan zijn voor de berekening. Om die reden 


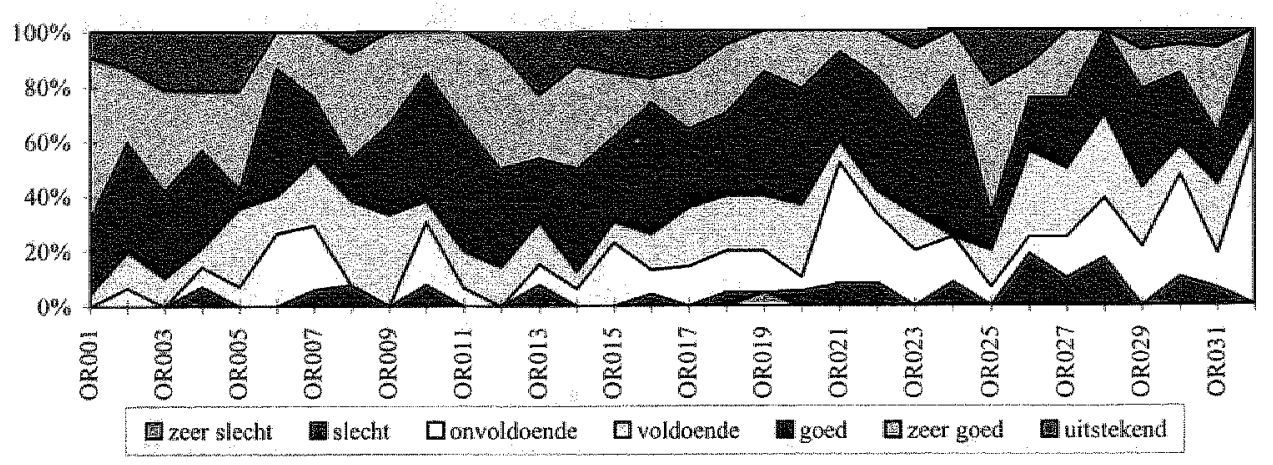

Figuur 5.2: Procentuele verdeling vary de consensuswatrden per casusstelling

zijn casusstellingen waarvoor minder dan drie beoordelingen hebben plaatsgevonden, niet in de tabel opgenomen. Indien één dan wel twee beoordelingen van een casusstelling hebben plaatsgevonden komt de consensuswaarde uit op 100\%, of op $50 \%$ wanneer het oordeel van beide beoordelingen aan dezelfde waarderingsmogelijkheden is gegeven.

De tabel moet als volgt worden gelezen.

- De kolom 'totaal (C/B)' bevat het aantal casusstellingen en beoordelingen die binnen de grenzen van de selectie vallen.

- In de kolommen 'waarderingsmogelijkheden' is opgenomen het aantal gegeven beoordelingen die behoren tot een casusstelling met een consensuswaarde van minimaal $50 \%$. Aangezien deze niet voorkomen in de kolom met de waarderingsmogelijkheid "zeer slecht" is deze kolom niet opgenomen in de tabel.

- In de kolom 'aantal (C/B)' is het aantal casusstellingen (C) en beoordelingen (B) opgenomen voor zover zij voorkomen bij gegeven waarderingen bij een Consensus Meetpunt van $50 \%$;

- De laatste kolom bevat de consensusindices die gericht zijn op casusstellingen en beoordelingen $\mathrm{CI}(\mathrm{c}, 50 \%)$ en $\mathrm{CI}(\mathrm{b}, 50 \%)$.

Uit figuur 5.3 blijkt dat:

- minimaal 4 en maximaal 22 casusstellingen een consensuswaarde hebben gelijk aan of groter dan $50 \%$ tegen in totaal 3 casusstellingen;

- minimal 8 en maximaal 62 beoordelingen een consensuswaarde hebben gelijk aan of groter dan $50 \%$ tegen in total 28 beoordelingen;

- de consensusindex gericht op de casusstellingen $(\mathrm{CI}(\mathrm{c}, 50 \%)$ varieerde van $16,67 \%$ tot en met $68,75 \%$, tegen in totaal $9,38 \%$; 
- de consensusindex gericht op de beoordelingen $(\mathrm{CI}(\mathrm{b}, 50 \%)$ varieerde van $16,72 \%$ tot en met $37,09 \%$, tegen in totaal $5,31 \%$.

\section{Waarderingsmogetijkheden}

selectilie
totaal
unt- zeer
(C / B) stekenid goed
goed rol-
doende doende

antal consensus-

(C $/ \mathrm{B})$ indices

$\mathrm{CI}(\mathrm{c}, 50 \%)$

$\mathrm{Cl}(\mathrm{b}, 50 \%)$

Aantal kantoorwisselingen, 527 beoordelingen; $100 \%$

\begin{tabular}{|c|c|c|c|c|c|c|c|c|c|}
\hline eerste kantoor & $32 / 169$ & & 30 & 177 & & 2 & 3 & $17 / 52$ & $53.13 \% / 30,77 \%$ \\
\hline 1 moal & $30 / 122$ & 2 & 6 & 21 & 4 & 3 & & $16 / 36$ & $53,33 \% / 29,51 \%$ \\
\hline $2 \operatorname{en} 3 \mathrm{mal}$ & $30 / 135$ & 2 & 23 & 9 & 8 & 4 & & $17 / 46$ & $56,66 \% / 34,07 \%$ \\
\hline$>3$ mall & $31 / 101$ & & 2 & 23 & & 3 & & $12 / 28$ & $38,71 \%, 27,72 \%$ \\
\hline
\end{tabular}

Ervaringsjaren, 527 beoordelingen; $100 \%$

$\begin{array}{lllllllll}0-9 \text { jaar } & 31 / 127 & 3 & 9 & 17 & 4 & 9 & 15 / 42 & 48,39 \% / 3 \%, 07 \% \\ 10-19 \text { jaar } & 32 / 234 & 6 & 17 & 14 & & 5 & 11 / 42 & 34,38 \% / 17,95 \% \\ 20-29 \text { jar } & 32 / 117 & 4 & 12 & 16 & 2 & 2 & 14 / 36 & 43,75 \% / 30,77 \% \\ 30-50 \text { jaar } & 26 / 49 & & 4 & 4 & 2 & & 5 / 10 & 19,23 \% / 20,41 \%\end{array}$

Leeftijden, 527 beoordelingen; $100 \%$

\begin{tabular}{|c|c|c|c|c|c|c|c|c|}
\hline $25-29$ jar & $24 / 39$ & & 4 & & 2 & 2 & 46 & $\underline{16,67 \% / 20,51 \%}$ \\
\hline $30-39$ jatr & $32 / 262$ & & 21 & 23 & 4 & 6 & $13 / 54$ & $40,63 \% / 20,61 \%$ \\
\hline $40-49$ jar & $32 / 166$ & 3 & 10 & 26 & 7 & 2 & $15 / 48$ & $46,88 \% / 28,92 \%$ \\
\hline $50-77 \mathrm{jar}$ & $28 / 60$ & & 4 & 14 & 2 & & $10 / 20$ & $35,71 \% / 33,33 \%$ \\
\hline
\end{tabular}

Gevolgde opleiding, 525 beoordelingen; $99,62 \%$

$\begin{array}{llllllll}\text { Unipenitaire } & 32 / 226 & 19 & 26 & 7 & 10 & 16 / 62 & 50,00 \% / 27,43 \% \\ \text { NWRA } & 32 / 299 & 17 & 24 & & 9 & 10 / 50 & 31,25 \% / 16,72 \%\end{array}$

overige

2

Aantal kantoorcollega ${ }^{\prime \prime} s_{3}, 522$ beoordelingen; $99,05 \%$

$\begin{array}{lcccccccc}\text { tot }<11 & 32 / 184 & 2 & 10 & 27 & 12 & 11 & 22 / 62 & 68,75 \% / 33,70 \% \\ \text { tort } 11-100 & 32 / 151 & 2 & 20 & 19 & 3 & 12 & 19 / 56 & 59,38 \% / 37,09 \% \\ \text { tot }>100 & 32 / 187 & 3 & 21 & 24 & 3 & 4 & 17 / 55 & 53,13 \% / 29,41 \% \\ \text { onbekend } & 5 & & & & & & \end{array}$

Totaal, 527 beoordelingen; $100 \%$

Toral

$32 / 527$

137

8

3/28 $\quad 9,38 \% / 5,31 \%$

Figuu 5.3 : Consensusindices bij en consensus meetpunt minimal geligk an $50 \%$ 
Opvallend is dat:

- bij meer dan driemaal wisselen van kantoor beide consensusindices lager liggen dan bij de andere subselecties, te weten: CI(c,50\%) met $28,8 \%$ en CI(b,50\%) met $11,9 \%$ lager;

- bij een ervaring van 10-19 jaar beide consensusindices aanzienlijk lager liggen dan het gemiddelde wan de twee subselecties minder dan 10 jaar en meer dan 19 jaar, te weten: $\mathrm{CI}(\mathrm{c}, 50 \%)$ met $25,4 \%$ en $\mathrm{CI}(\mathrm{b}, 50 \%)$ met $43,8 \%$ lager;

- bij een NIVRA-Nyenrode opleiding beide consensusindices aanzienlijk lager liggen dan bij een universitaire opleiding, te weten: CI (c,50\%) met $37,5 \%$ en $\mathrm{CI}(\mathrm{b}, 50 \%)$ met $39,0 \%$ lager;

- bij een aantal kantoorcollega's van meer dan 100 kantoorgenoten beide consensusindices aanzienlijk lager liggen dan het gemiddelde van de twee subselecties minder dan 100, te weten: CI (c,50\%) met 17,1\% en CI(b,50\%) met 16,9\% lager.

Deze op zich interessante afwijkingen zouden object van onderzoek kunnen zijn in latere studies. In deze studie is hierop geen nader onderzoek verricht.

\section{Conclusie}

Gelet op het lage aantal casusstellingen met gelijkluidende antwoorden, in totaal bezien, kan niet geconcludeerd worden dat aantoonbaar is gemaakt dat sprake is van consensus tussen de oordelen van accountants aangaande de toereikendheid van administratief-organisatorische processen. Wel is gebleken dat indien verschillende doorsneden worden gemaakt de consensus in de gegeven beoordelingen sterk fluctueert. Naar wat de verklarende factoren hiervan zijn kan object wan onderzoek zijn in een vervolgonderzoek.

Op basis van het bovenstaande moet de eerste hypothese worden verworpen. De consequentie hiervan is dat geen ondersteuning kan worden gegeven aan de stelling van Meservy, Bailey en Johnson [1986] dat het gemis van een normatief model ${ }^{6}$ van beheersingsmatregelen kan worden opgevangen door de consensus van de beoordelingen van accountants als uitgangspunt te nemen.

\subsubsection{Consensus in oordeel, per aantal jaren werkervaring}

$\mathrm{Bij}$ het formuleren van de tweede hypothese werd in hoofdstuk 3 verondersteld dat bij toename van de jaren ervaring ook de consensus tussen de oordelen van de accountants zou toenemen. Enerzijds was deze veronderstelling gebaseerd op uitkomsten van diverse onderzoeken [Bédard, 1994; Bédard en Graham, 1994; Bonner en Pennington, 1991]. Daarin werd geconstateerd dat naarmate accountants langer werkzaam zijn binnen de accountantsprofessie en meer ervaring verkrijgen, hun kemnis zal groeien en die kennis beter in hun geheugen georganiseerd zal worden. 
Anderzijds was deze veronderstelling gebaseerd op het feit dat administratief-organisatorische processen al gedurende enige tijd richtingbepalend zijn voor de controlemethodologieën van de accountantskantoren [Meservy, Bailey en Johnson, 1986]. De tweede hypothese was als volgt geformuleerd:

H2: Een toename van het aantal jaren werkervaring in het pakgebied accountancy heeft een positieve invloed op de consensus tussen de oordelen van de accountants.

Bijlage 15: 'Verdeling waardeoordelen per ervaringsjaren en beoordelingswaarden" bevat de door de accountants gegeven waardeoordelen. De jaren werkervaring zijn gegroepeerd in vier subselecties, drie met een range van 10 ervaringsjaren en de laatste van 20 ervaringsjaren. In deze latste groep zijn twee beoordelende accountants opgenomen met meer dan 40 ervaringsjaren, te weten éen met 42 ervaringsjaren en één met 50 ervaringsjaren. Binnen de subselecties zijn de casusstellingen gegroepeerd in zes groepen, naar het aantal soorten beheersingsmaatregelen dat in de casusstellingen is opgenomen.

Met behulp van One-Way ANOVA zijn twee analyses als volgt uitgevoerd:

- In de eerste analyse, de ANOVA (1), zijn de beoordeelde casusstellingen per groep als uitgangspunt genomen. Binnen een groep casusstellingen met hetzelfde aantal soorten beheersingsmaatregelen is nagegaan of een significant verschil geconstateerd kon worden in de spreiding van de beoordelingen gegeven door de verschillende subselecties 'jaren werkervaring'. Op grond van hypothese 2 mag verwacht worden dat een significant verschil in de spreiding van de gegeven beoordelingen geconstateerd zal worden. De hierbij behorende nulhypothese luidt: het niet afwijken van de varianties in de beoordeling van casusstellingen met hetzelfde aantal soorten beheersingsmaatregelen bij de verschillende subselecties 'jaren werkervaring';

- In de tweede analyse, de ANOVA (2), zijn de subselecties "jaren werkervaring" als uitgangspunt genomen. Binnen een subselectie is nagegaan of een significant verschil geconstateerd kon worden in de spreiding van de beoordelingen gegeven ten aanzien van de groepen casusstellingen. Deze tweede analyse is niet rechtstreeks uit hypothese 2 af te leiden. De doelstelling van deze analyses is vast te stellen of in de subselecties de beoordelingen van casusstellingen variëren indien het aantal soorten beheersingsmaatregelen variẻert. De hierbij behorende nulhypothese luidt: het niet afwijken van de varianties in de beoordeling van casusstellingen met een verschillend antal soorten beheersingsmaatregelen binnen één subselectie 'jaren werkervaring'.

Op basis van ANOVA (1) is geen significant verschil geconstateerd wardoor de nulhypothese niet kon worden verworpen. 


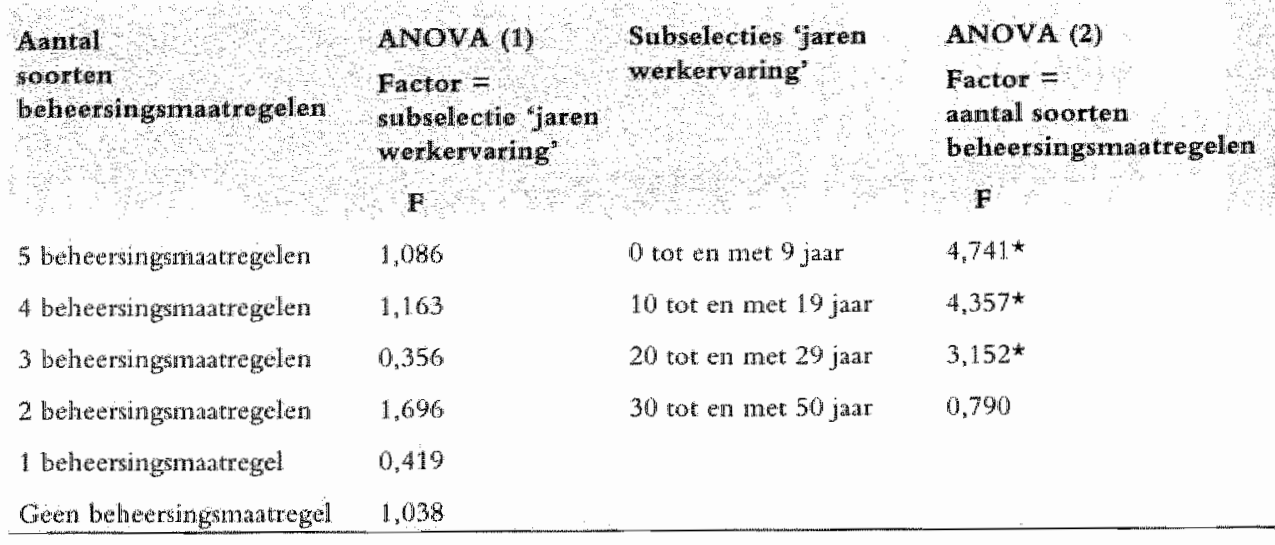

Figuar 5.4: AMOVA bij stbelecties "jaren werkerwaring". (*igrificant $\mathrm{p} \leq 0,05$ )

Op basis van ANOVA (2) zijn significante verschillen geconstateerd waardoor de nulhypothese kon worden verworpen. Uitzondering hierop is de subselectie 'jaren werkervaring' 30 tot en met 50 jaar. Daarvoor konden evenwel, door het geringe aantal waarnemingen ${ }^{7}$, geen post-hoc vergelijkingen worden berekend ${ }^{8}$.

Tevens is met behulp van de Spearman correlatiecoëfficiënt nagegaan of een correlatie bestaat binnen iedere subselectie 'jaren werkervaring' tussen de gegeven beoordelingen en het aantal soorten beheersingsmaatregelen. De resultaten zijn in figuur 5.5 weergegeven.

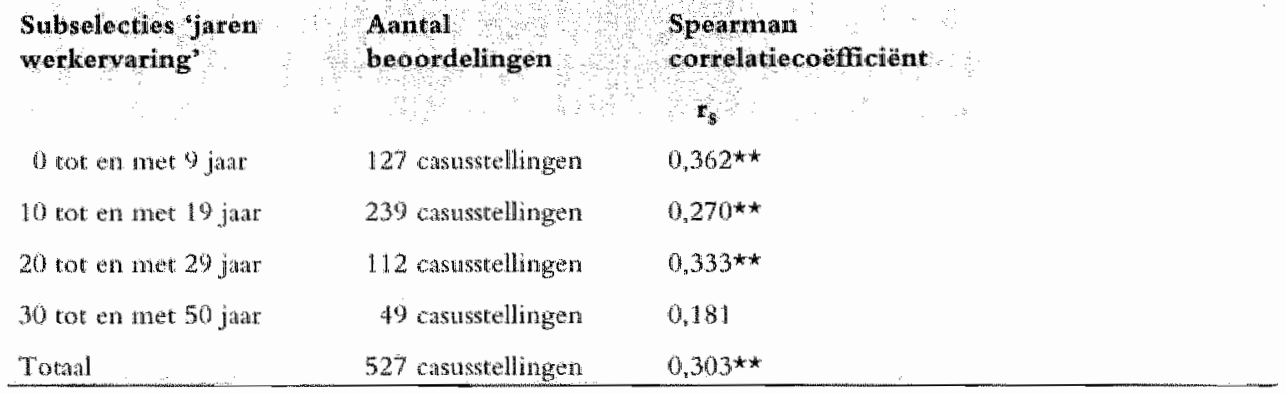

Fignur 5.5: Speaman conedatiecoeffichënt bij beoondelingswarde bij stabelecties "jaren werkervaring" (** .01 lewel (1-tailed) ?

Met uitzondering van de subselectie 30 tot en met 50 jaar is bij alle subselecties een significante correlatie gevonden tussen de door de accountant gegeven beoordelingen gegroepeerd naar 'jaren werkervaring' en het aantal soorten beheersingsmaatregelen dat in de casusstelling is opgenomen. 
In bijlage 15: "Verdeling waardeoordelen per ervaringsjaren en beoordelingswaarden' zijn per subselectie 'jaren werkervaring' de beoordelingswaarden berekend zoals beschreven in paragraaf 4.4.4.2. Indien per subselectie 'jaren werkervaring' en daarbinnen per groep casusstellingen met een verschillend aantal soorten beheersingsmaatregelen, gekeken wordt naar het verloop van de beoordelingswarden ten opzichte van de totale beoordelingswarde van die subselectie, komt bij alle subselecties 'jaren werkervaring' een negatieve tendens in de waardering naar voren. Deze negatieve tendentie impliceert dat naarmate het aantal soorten beheersingsmaatregelen binnen een subselectie 'jaren werkervaring' afneemt, ook de waarde van de beoordeling afneemt. In bijlage 15: "Verdeling waardeoordelen per ervaringsjaren en beoordelingswaarden' is dit grafisch weergegeven.

Opvallend is dat indien de totale beoordelingswaarde van de verschillende subsecties "jaren werkervaring", zoals opgenomen in bijlage 15: "Verdeling waardeoordelen per ervaringsjaren en beoordelingswaarden', met elkaar worden vergeleken een positieve verschuiving blijkt naarmate meer werkervaring wordt verkregen.

- De beoordelingswaarde van de totale subselectie met 0 tot en met 9 jaren werkervaring bedraagt: 4,5354 .

- De beoordelingswaarde van de totale subselectie met 30 tot en met 50 jaren werkervaring bedraagt: 4,8980 .

Deze verschuiving zou kunnen impliceren dat naarmate de jaren werkervaring toenemen, positiever op de voorgelegde casusstellingen wordt gereageerd. Nader onderzoek zou hierop een antwoord kunnen geven.

\section{Conclusies}

Doordat geen significant verschil is geconstateerd tussen de varianties in de beoordelingen van accountants die tot de verschillenden subselecties 'jaren werkervaring' behoren, over casusstellingen met hetzelfde aantal soorten beheersingsmaatregelen, wordt de eerste nulhypothese gehandhaafd. Dit impliceert dat niet is vastgesteld dat het aantal ervaringsjaren van invloed is op de variantie in de beoordeling van de casusstellingen. Op grond hiervan moet de tweede hypothese worden verworpen.

Wel kan op basis van de tweede ANOVA analyse, de Spearman correlatiecoëfficiënt en het verloop in de beoordelingswaarden de conclusie worden getrokken clat een correlatie bestaat tussen de door de accountants gegeven waarderingen en het aantal beheersingsmaatregelen begrepen in een casusstelling. Deze conclusie kam voor alle subselecties worden getrokken met uitzondering voor de subselectie 30 tot en met 50 jaar werkervaring. Op basis van deze uitkomsten kan de conclusie getrokken worden dat de accountants behorende tot de verschillende subselecties op eenzelfde wijze aankijken tegen het aantal soorten beheersingsmaatregelen dat in een casusstelling is opgenomen. 


\subsubsection{Consensus in oordeel, per aantal soorten beheersingsmaatregelen}

Bij het formuleren van de derde hypothese werd in hoofdstuk 3 verondersteld dat het geheel van de mix van beheersingsmaatregelen bepalend is of al dan niet sprake is van een toereikend geheel van beheersingsmaatregelen. Onderlinge substitutionaliteit van beheersingsmaatregelen werd daarbij verondersteld. Dit was met name gebaseerd op de afwezigheid van een eenduidige normstelling, de aandacht die tijdens de opleiding aan de vijf soorten beheersingsmaatregelen wordt gegeven en de opbouw van prototypische mentale modellen wartegen de werkelijkheid wordt afgezet. De derde hypothese valt in twee delen uiteen welke als volgt waren geformuleerd:

H3a: Niet het soort beheersingsmaatregel maar het antal werschillende soorten beheersingsmatregelen dat in een te beoordelen administratief-organisatorisch proces is opgenomen heeft invloed op de consensus tussen de oordelen van de accountants.

H3b: Een toename van het aantal malen dat een gelijke mix van soorten inteme beheersingsmaatregelen voorkont in de praktijk van de accourtant heeft een positieve invloed op de consensus tussen de oordelen van de accountants.

\subsubsection{Consensus in oordeel, per mix van beheepsingstnaatregelen}

Bijlage 16: "Verdeling waardeoordelen per beheersingsmaatregel en beoordelingswaarden' bevat de door de accountants gegeven waardeoordelen. De beheersingsmaatregelen zijn gegroepeerd naar een vijftal subselecties 'soort beheersingsmaatregel'. Uit bijlage 12: 'Overzicht beoordeelde casusstellingen en beheersingsmaatregelen' blijkt dat, doordat meerdere beheersingsmaatregelen aanwezig kunnen zijn binnen een casusstelling (de zogenaamde mix van beheersingsmaatregelen), 1311 beoordelingen op deze wijze bekeken en ingedeeld konden worden naar de vijf subselecties 'soort beheersingsmaatregel'.

Binnen de subselecties zijn de casusstellingen gegroepeerd in vijf groepen, naar het aantal soorten beheersingsmaatregelen dat in de casusstellingen is opgenomen. De groep met 'Geen Beheersingsmaatregelen' kan bij deze selectie niet voorkomen aangezien altijd minimaal één van de beheersingsmaatregelen aanwezig moet zijn.

Met behulp van One-Way ANOVA zijn twee analyses als volgt uitgevoerd:

- In de eerste analyse, de ANOVA (1), zijn de beoordeelde casusstellingen per groep als uitgangspunt genomen. Binnen een groep casusstellingen met hetzelfde aantal soorten beheersingsmaatregelen is nagegaan of een significant verschil geconstateerd kon worden in de spreiding van de beoordelingen gegeven door de verschillende subselecties 'soort beheersingsmaatregel'. Op grond van hypothese $3 \mathrm{a} \mathrm{mag}$ verwacht worden dat geen significant verschil in de spreiding van de gegeven 
beoordelingen geconstateerd zal worden. De hierbij behorende nulhypothese luidt: het niet afwijken van de varianties in de beoordeling van casusstellingen met hetzelfde aantal soorten beheersingsmaatregelen bij de verschillende subselecties 'soort beheersingsmaatregel';

- In de tweede analyse, de ANOVA (2), zijn de subselecties 'soort beheersingsmaatregel' als uitgangspunt genomen. Binnen een subselectie is nagegaan of een significant verschil geconstateerd kon worden in de spreiding van de beoordelingen gegeven ten aanzien van de groepen casusstellingen. Deze tweede analyse is niet rechtstreeks uit van hypothese 3 a af te leiden. De doelstelling van deze analyses is vast te stellen of in de subselecties de beoordelingen van casusstellingen variëren indien het aantal soorten beheersingsmaatregelen variëert. De hierbij behorende nulhypothese luidt: het niet afwijken van de varianties in de beoordeling van casusstellingen met een verschillend aantal soorten beheersingsmaatregelen binnen één subselectie 'soort beheersingsmaatregel'.

Op basis van ANOVA (1) is geen significant verschil geconstateerd watrdoor de nulhypothese niet kon worden verworpen. Uitzondering hierop is de subselectie met 2 beheersingsmaatregelen welke significant is op basis van $p=0,024$. De berekende post-hoc vergelijkingen gaven evenwel geen nadere indicaties op grond waarvan een andere conclusie getrokken moet worden.

Op basis van ANOVA (2) zijn significante verschillen geconstateerd waardoor de nulhypothese kon worden verworpen. De resultaten zijn in figuur 5.6 weergegeven.

Tevens is met behulp van de Spearman correlatiecoëfficiënt nagegaan of een correlatie bestaat binnen iedere subselectie 'soort beheersingsmaatregel" tussen de gegeven beoordelingen en het aantal soorten beheersingsmaatregelen. De resultaten zijn in figuur 5.7 weergegeven.

Bij alle subselecties is een significante correlatie gevonden tussen de door de accountant gegeven beoordelingen gegroepeerd naar 'soort beheersingsmatregel' en het aantal soorten beheersingsmaatregelen dat in de casusstelling is opgenomen.

In bijlage 16: 'Verdeling waardeoordelen per beheersingsmaatregel en beoordelingswaarden' zijn per subselectie 'soort beheersingsmaatregel' de beoordelingswaarden berekend zoals beschreven in paragraaf 4.4.4.2. Indien per subselectie 'soort beheersingsmaatregel' en daarbinnen per groep casusstellingen met een verschillend aantal soorten beheersingsmaatregelen, gekeken wordt naar het verloop van de beoordelingswaarden ten opzichte van de totale beoordelingswaarde van die subselectie, komt bij alle subselecties 'soort beheersingsmaatregel' een negatieve tendens in de waardering naar voren. Deze negatieve tendentie impliceert dat naarmate het 


\begin{tabular}{|c|c|c|c|}
\hline $\begin{array}{l}\text { Aantal } \\
\text { soonten } \\
\text { beheersings manatregedilen }\end{array}$ & 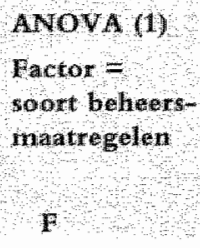 & $\begin{array}{l}\text { Subselecties soort } \\
\text { beheersingsmatragel' }\end{array}$ & $\begin{array}{l}\text { ANOVA (2) } \\
\text { Factor = } \\
\text { anntal soorten } \\
\text { behersings- } \\
\text { manatregelen } \\
\mathrm{F}\end{array}$ \\
\hline 5 belieeningsmatregelen. & 0,000 & $\begin{array}{l}\text { Procetbeheering }(P) \text {, } \\
252 \text { castasstellinger }\end{array}$ & $2.430 *$ \\
\hline 4 beheerningsmatregelen & 0,584 & $\begin{array}{l}\text { Financiele belaeersing }(\mathrm{F}) \\
263 \text { casusstellingen }\end{array}$ & $11,249 x$ \\
\hline 3 beheersingsmaturgelen & 1,195 & $\begin{array}{l}\text { Organisatorische beheersing (O), } \\
265 \text { cosustelingen }\end{array}$ & $5,932^{*}$ \\
\hline 2 beheersings mafturgelen & 2,849 * & $\begin{array}{l}\text { Informatiebeheersing }(1) \\
267 \text { casusstellingen }\end{array}$ & $9,335^{*}$ \\
\hline 1 beheersingsinatragel & 2,010 & $\begin{array}{l}\text { Prestatiabeheersing }(E) \\
264 \text { casusstellingen }\end{array}$ & $3,711 *$ \\
\hline
\end{tabular}

Pigurur 5.6: ANOVA bij subselectios "soon beheersingsmatregel"

(* significant $\leq 0,05$ )

\section{Subselecties soort belheersingsinanatregel?}

Procesbetherening (P)

Financiête beheersing (F)

Orgmisatonische beheersing (O)

adjustrighth Lormatiebeheersing (I)

Prestatichehersing (E)

Total exclusief dubbeltellingen

\section{Aandan \\ beoordelinger}

252 casusgellingen

263 casusstellingen

265. casusstellingen

267 cesusstellingen

264 casustellingen

527 casusstellingen

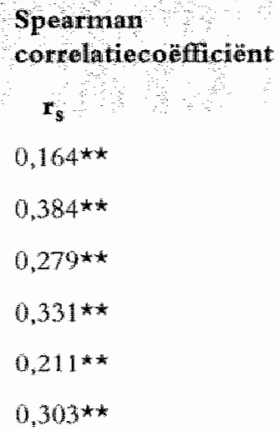

Figum 5.7: Spearman correlatiecoefficient bij beoondelingswande bij subselectes 'soort beheersingsmantregel' (**.01 level (1-tililed)

aantal soorten beheersingsmaatregelen bimnen een subselectie 'soort beheersingsmatregel" afneemt, ook de warde van de beoordeling afneemt. In bijlage 16: 'Verdeling waardeoordelen per beheersingsmaatregel en beoordelingswaarden' is dit grafisch weergegeven.

Opvallend is dat als de totale beoordelingswaarde van de verschillende subselecties 'soort beheersingsmaatregel' met elkaar worden vergeleken blijkt dat niet ieder soort beheersingsmaatregel even zwaar wordt gewogen en kan een rangvolgorde worden vastgesteld. 
1. Procesbeheersing $(\mathrm{P})$ met een totale beoordelingswaarde van:

5,1310 .

2. Organisatiebeheersing $(\mathrm{O})$ met een totale beoordelingswaarde van: $\quad 5,0679$.

3. Prestatiebeheersing $(E)$ met een totale beoordelingswaarde van: 4,9924 .

4. Informatiebeheersing (I) met een totale beoordelingswarde van: 4,8090 .

5. Financiële beheersing (F) met een totale beoordelingswaarde van: 4,7681 . In hoeverre door accountants hiermee een 'voorkeur' wordt uitgesproken voor een soort beheersingsmaatregel is in deze studie geen nader object van onderzoek gewest. Nader onderzoek zou hierop een antwoord kunnen geven.

\section{Conclusie}

Doordat geen significant verschil is geconstateerd tussen de varianties in de beoordelingen door accountants gegroepeerd naar de verschillende subselecties "soort beheersingsmaatregel', over casusstellingen met hetzelfde aantal soorten beheersingsmaatregelen, wordt de eerste nullhypothese gehandhaafd. Dit impliceert dat niet is vastgesteld dat de soort beheersingsmaatregel van invloed is op de variantie in de beoordelingswaarde van de casusstellingen.

Doordat wel significante verschillen zijn geconstateerd tussen de variaties in de beoordelingen door accountants gegroepeerd naar de verschillende subselecties 'aantal soorten beheersingsmaatregelen', over casusstellingen met dezelfde soort beheersingsmatregel, wordt de tweede nulhypothese verworpen. Dit impliceert dat is vastgesteld dat het aantal soorten beheersingsmaatregelen van invloed is op de variantie in de beoordelingswaarde van de casusstellingen. Op grond van deze twee bevindingen kan het eerste deel van de derde hypothese worden gehandhaafd.

Mede op basis van de Spearman correlatiecoëfficiënt en het verloop in de beoordelingswaarden kan de conclusie worden getrokken dat een correlatie bestaat tussen de door de accountants gegeven waarderingen gegroepeerd naar de verschillende subselecties 'soort beheersingsmaatregel' en het aantal beheersingsmaatregelen begrepen in een casusstelling. Op basis van deze uitkomsten kan de conclusie getrokken worden dat in de waarderingen van de accountants gegroepeerd naar de verschillende subselecties 'soort beheersingsmaatregel' rekening gehouden wordt met her aantal soorten beheersingsmaatregelen dat in een casusstelling is opgenomen.

\subsubsection{Consensus in oordeel, per voorkomen van casusstellingen in portefenille}

Bijlage 17: 'Verdeling wardeoordelen per voorkompercentage en beoordelings"waarden' bevat de door de accountants gegeven waardeoordelen. Op grond van het door de accountants aangegeven percentage waarmee een soortgelijke casusstelling in hun praktijk voorkomt zijn de casusstellingen gegroepeerd in vijf subselecties met een gelijke range. Binnen de subselecties zijn de casusstellingen gegroepeerd in zes 
groepen, mar het aantal soorten beheersingsmaatregelen dat in de casusstellingen is. opgenomen.

Met behulp van One-Way ANOVA zijn twee analyses als volgt uitgevoerd:

- In de eerste analyse, de ANOVA (1), zijn de beoordeelde casusstellingen per groep als uitgangspunt genomen. Binnen een groep casusstellingen met hetzelfde aantal: soorten beheersingsmatregelen is nagegaan of een significant verschil geconstateerd kon worden in de spreiding van de beoordelingen gegeven door de verschillende subselecties "voorkompercentages". Op grond van hypothese $3 \mathrm{~b}$ mag verwacht worden dat een significant verschil in de spreiding van de gegeven beoordelingen geconstateerd zal worden. De hierbij behorende nulhypothese luidt: het niet afwijken van de varianties in de beoordeling van casusstellingen met hetzelfde antal soorten beheersingsmaatregelen bij de verschillende subselecties "voorkompercentages";

- In de tweede analyse, de ANOVA (2), zijn de subselecties "voorkompercentages" als uitgangspunt genomen. Binnen een subselectie is magegaan of een significant verschil geconstateerd kon worden in de spreiding van de beoordelingen gegeven ten aanzien van de groepen casusstellingen. Deze tweede analyse is niet rechtstreeks uit lyypothese $3 \mathrm{~b}$ af te leiden. De doelstelling van deze analyses is vast te stellen of in de subselecties de beoordelingen van casusstellingen variëren indien het aantal soorten beheersingsmaatregelen variëert. De hierbij behorende nulhypothese luidt: het niet afwijken van de varianties in de beoordeling van casusstellingen met een verschillend aantal soorten beheersingsmatregelen binnen één subselectie "voorkompercentage'.

Op basis van ANOVA (1) is geen significant verschil geconstateerd waardoor de nulhypothese niet kon worden verworpen.

Op basis van ANOVA (2) zijn significante verschillen geconstateerd bij twee subselecties te weten $0 \%$ - $20 \%$ en $61 \%$ - $80 \%$. Bij de voorkompercentagegroepen $21 \%$ $40 \%$ en $41 \%-60 \%$ zijn geen significante verschillen geconstateerd ${ }^{9}$. Op grond hiervan kan de nulhypothese niet worden verworpen. De resultaten zijn in figuur 5.8 opgenomen.

Tevens is met behulp van de Spearman correlatiecoëfficiënt nagegaan of een correlatie bestaat binnen iedere subselectie 'voorkompercentage' tussen de gegeven beoordelingen en het aantal soorten beheersingsmaatregelen. De resultaten zijn in figurur 5.9 weergegeven.

Met uitzondering van de subselectie $41 \%-60 \%$ is een significante correlatie gevonden tussen de door de accountant gegeven beoordelingen gegroepeerd naar 


\begin{tabular}{|c|c|c|c|}
\hline $\begin{array}{l}\text { Aantal } \\
\text { soonten } \\
\text { beheersingsmaatregelen }\end{array}$ & $\begin{array}{l}\text { ANOVA }(1), \\
\text { Factor = nowarkom, } \\
\text { percentage groepen } \\
\text { F }\end{array}$ & $\begin{array}{l}\text { Stribsellacties } \\
\text { Yoorkompercentage }\end{array}$ & 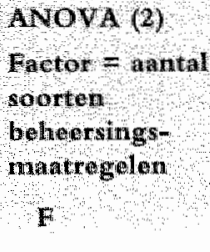 \\
\hline 5 beheersingsmatregelen & $1,4,39$ & $\begin{array}{l}0 \%-20 \% \\
299 \text { catsusstellingen }\end{array}$ & $7.335 *$ \\
\hline 4 beheersingsmatregelen & 2,486 & $\begin{array}{l}21 \%-40 \% \\
121 \text { casusstellingen }\end{array}$ & 1,289 \\
\hline 3 beheersingmatregelen & 1,107 & $\begin{array}{l}41 \%-60 \% \\
69 \text { casusstellingen }\end{array}$ & 1.380 \\
\hline 2 beheersingsmaatregelen & 0.857 & $\begin{array}{l}61 \%-80 \% \\
37 \text { casusstellingen }\end{array}$ & $3,129 *$ \\
\hline 1. beheersingsmaatregel & 0,102 & $\begin{array}{l}81 \%-100 \% \\
1 \text { casusstelling }\end{array}$ & mistl te bepenlers \\
\hline Geen beheersingsmaatre gel & 0,657 & & \\
\hline
\end{tabular}

Figuur 5.8: ANOVA bij subselecties "zoorkompercentage" (*significant $p \leq 0,05$ )

\begin{tabular}{|c|c|c|}
\hline $\begin{array}{l}\text { subselecties } \\
\text { voorkompercentage' }\end{array}$ & $\begin{array}{l}\text { Aantal } \\
\text { beoordelingen }\end{array}$ & $\begin{array}{l}\text { Spearman } \\
\text { correlatiecoufficient } \\
\mathrm{rs}\end{array}$ \\
\hline $0 \%-20 \%$ & 299 casusstellingen & $0,327 * *$ \\
\hline $21 \%-40 \%$ & 121 casusstellingen & $0,217 k$ \\
\hline $4.1 \%-60 \%$ & 69 casusstellingen & 0,177 \\
\hline $61 \%-80 \%$ & 37 castusstellingen & $0,4,44 \ldots$ \\
\hline $81 \%-1009$ & 1 casusstelling & mett to bepalen \\
\hline Totaal & 527 asusstellingen & $0,303 * *$ \\
\hline
\end{tabular}

Figuar 5.9: Spearman correlatiecoefficient bij beoondelingswatde bij subselecties "voorkompetcentage" (*. 01 levell $(1-$ tailed $)$

'voorkompercentages' en het aantal soorten beheersingsmaatregelen dat in de casusstelling is opgenomen.

In bijlage 17: 'Verdeling waardeoordelen per voorkompercentage en beoordelingswaarden' zijn per subselectie 'voorkompercentage' de beoordelingswaarden berekend zoals beschreven in paragraaf 4.4.4.2. Indien per subselectie "voorkompercentage' en daarbinnen per groep casusstellingen met een verschillend aantal soorten beheersingsmaatregelen, gekeken wordt naar het verloop van de beoorde- 
lingswaarden ten opzichte van de totale beoordelingswaarde van die subselectie, komt bij alle subselecties 'soort beheersingsmaatregel' een negatieve tendens in de waardering naar voren. Deze negatieve tendentie impliceert dat naarmate het aantal soorten beheersingsmaatregelen binnen een subselectie 'voorkompercentage' afneemt, ook de waarde van de beoordeling afneemt. In bijlage 17: 'Verdeling waardeoordelen per voorkompercentage en beoordelingswaarden' is dit grafisch weergegeven.

Opvallend is dat als de totale beoordelingswaarde van de verschillende subsecties 'voorkompercentage' (zoals opgenomen in bijlage 17: 'Verdeling waardeoordelen per voorkompercentage en beoordelingswaarden') met elkaar worden vergeleken, een negatieve tendens in de beoordeling blijkt naar mate de casusstelling vaker voorkomt. Doordat in de subselectie $81-100 \%$ slechts één waarneming zit is deze groep buiten beschouwing gelaten.

- De beoordelingswaarde van de totalle subselectie met voorkompercentage 0 - $20 \%$ bedraagt: 4,9231 .

- De beoordelingswaarde van de totale subselectie met voorkompercentage $21-40 \%$ bedraagt: 4,6116 .

- De beoordelingswaarde van de totale subselectie met voorkompercentage $41-60 \%$ bedraagt: 4,4928 .

- De beoordelingswaarde van de totale subselectie met voorkompercentage $61-80 \%$ bedraagt: 4,5405 .

Deze verschuiving zou kunnen impliceren dat naarmate een casusstelling vaker voorkomt in de portefeuille van de accountant, negatiever wordt gereageerd op de te beoordelen casusstellingen. Nader onderzoek zou hierop een antwoord kunnen geven.

\section{Conclusie}

Doordat geen significant verschillen zijn geconstateerd tussen de varianties in de beoordelingen door accountants enerzijds gegroepeerd naar de verschillende subselecties "voorkompercentage", over casusstellingen met hetzelfde aantal soorten beheersingsmaatregelen en anderzijds gegroepeerd naar de verschillende subselecties 'aantal soorten beheersingsmaatregelen', over casusstellingen met eenzelfde 'voorkompercentage', worden de beide nulhypotheses gehandhaafd. Dit impliceert dat niet is vastgesteld dat het 'voorkompercentage' van invloed is op de variantie in de beoordelingswaarde van de casusstellingen. Op grond hiervan moet het tweede deel van de derde hypothese worden verworpen.

Wel kan op basis van de Spearman correlatiecoëfficiënt en het verloop in de beoordelingswaarden de conclusie worden getrokken dat een correlatie bestaat tussen de 
door de accountants gegeven waarderingen gegroepeerd naar de verschillende subselecties 'voorkompercentage' en het aantal beheersingsmaatregelen begrepen in een casusstelling. Op basis van deze uitkomsten kan de conclusie getrokken worden dat in de waarderingen van de accountants gegroepeerd naar de verschillende subselecties 'voorkompercentage' rekening gehouden wordt met het aantal soorten beheersingsmatregelen dat in een casusstelling is opgenomen.

\subsubsection{Consensus in oordeel, naar belang van soort beheersingsnaatregel}

Bij het formuleren van de vierde hypothese werd in hoofdstuk 3 verondersteld dat onder accountants consensus bestaat over het belang dat gehecht wordt aan een soort beheersingsmaatregel. Enerzijds was deze veronderstelling gebaseerd op de grote andacht die binnen de opleidingen tot accountant aan de beheersingsmaatregelen wordt gegeven, onder meer in de hoofdvakken Administratieve Organisatie en Leer van de Accountantscontrole. Anderzijds komt de accountant bij zijn werkzaamheden in aanraking met deze beheersingsmaatregelen. Met behulp van deze beheersingsmaatregelen ontwikkelt de accountant een al eerder genoemd prototypisch mentaal model ${ }^{10}$.

De vierde hypothese was als volgt geformuleerd:

\section{H4: Accountants hebben geen poorkeur woor een bepaald soort beheersingstnatregel}

Van de 199 accountants hebben 187 een ranking gegeven naar belangrijkheid van de vijfsoorten beheersingsmaatregel. Om vast te stellen welke soort beheersingsmaatregel als belangrijkste is aan te merken is in analogie met de 'beoordelingswaarde' zoals weergegeven in paragraaf 4.4.4.2., de 'voorkeurswaarde' berekend. Om deze berekening te kunnen uitvoeren is aan de gregeven ranking naar belangrijkheid een gewicht $(G)$ gegeven, startend met de 5e 'voorkeursplaats' met gewicht 1 en oplopend tot de 1e 'voorkeursplaats' met het gewicht 5 .

De voorkeurswaarde van een beheersingsmaatregel wordt als volgt berekend:

$$
V W=\frac{\sum_{v p=1}^{v p=5}(R p p \times G v p)}{R}
$$

- $\mathrm{VW}=$ voorkeurswaarde

- $\mathrm{R}$ = aantal uitgesproken voorkeuren

- $\mathrm{vp}=$ voorkeursplaats

- $\operatorname{Grp}=$ gewicht per voorkeursplaats 
De totale voorkeurswaarde kan liggen tussen het getal 1 en $5^{11}$. In figuur 5.10 . is de procentuele verdeling en de voorkeurswaarde weergegeven. Van de 187 accountants oordeelden $40,11 \%$ de groep Proces beheersingsmaatregelen als de belangrijkste beheersingsmaatregel. $45,45 \%$ beoordeelde de groep Informatie beheersingsmaatregelen als het minst belangrijk. Als naast de eerste en de vijfde plaats ook wordt gekeken naar de tweede en de vierde plats blijkt de voorkeur nog groter: $61,50 \%$ $(40,11 \%+21,39 \%)$ voor de groep Proces beheersingsmaatregelen als belangrijkste beheersingsmaatregel en met $72,72 \%(27,27 \%+45,45 \%)$ voor de groep Informatie beheersingsmaatregelen als minst belangrijke beheersingsmaatregel.

\begin{tabular}{|c|c|c|c|c|c|c|}
\hline \multirow[b]{2}{*}{ Noorkeur } & \multicolumn{2}{|c|}{ Beheersing gmatregelen } & \multirow[b]{2}{*}{$\begin{array}{l}\text { Organisato } \\
\text { rische } \\
\text { beheersing }\end{array}$} & \multirow[b]{2}{*}{$\begin{array}{l}\text { Informatie } \\
\text { beheersing }\end{array}$} & \multirow[b]{2}{*}{$\begin{array}{l}\text { Prestatie } \\
\text { beheorsilng }\end{array}$} & \multirow[b]{2}{*}{ Totaal } \\
\hline & $\begin{array}{l}\text { Proces } \\
\text { beheersing }\end{array}$ & $\begin{array}{l}\text { Fhanciele } \\
\text { Toheersing }\end{array}$ & & & & \\
\hline $1 \mathrm{e} \mathrm{plabs}$ & $40,11 \%$ & $13,37 \%$ & $20,86 \%$ & $5,88^{20}$ & $19.78 \%$ & $100 \%$ \\
\hline $2 \mathrm{e}$ plats & $21,39 \%$ & $23,53 \%$ & $23,53 \%$ & $6,96 \%$ & $24.59 \%$ & $100 \%$ \\
\hline $3 \mathrm{eph} A \mathrm{An}$, & $16,58 \%$ & $30,48 \%$ & $18,72 \%$ & $14,4,4 \%$ & $19,78 \%$ & $100 \%$ \\
\hline 4 eplonts & $10,70 \%$ & $24,60 \%$ & $22,99 \%$ & $27,27 \%$ & $14,44 \%$ & $100 \%$ \\
\hline $5 \mathrm{eplonat}$ & $11,22 \%$ & $8.02 \%$ & $13,90 \%$ & $45,45 \%$ & $21,41 \%$ & $100 \%$ \\
\hline Totial. & $100 \%$ & $100 \%$ & $100 \%$ & $100 \%$ & $100 \%$ & \\
\hline Woorkellywharde & 3,6845 & 3,0963 & 3,1444 & 2,0053 & 3,0695 & \\
\hline In 0 eenste plats & $100 \%$ & $84,0 \%$ & $85,3 \%$ & $54.4 \%$ & 83,3 & \\
\hline Aarking & 1ste plats & 3e plaats & 2e plaars: & $5 \mathrm{e}$ plats & $4 \mathrm{e}$ plaats & \\
\hline
\end{tabular}

Figunir 5. 10: Procentnele verdeling van ranking van de voorkeur en de voorkeurswaarde

Ook kan worden gekeken naar de combinatie van beheersingsmatregelen met de voorkeursplaatsen één en twee. Enerzijds wordt als uiterste zichtbaar de combinatie van de beheersingmaatregelen Proces (P) en Organisatie (O). Daarvoor werd 32 keer, in 17,11\%, de voorkeur uitgesproken. Ander zijds wordt de combinatie van de beheersingsmaatregelen Informatie (I) en Financieel $(F)$ in het geheel niet genoemd als belangrijkste beheersingsmatregelen. In figuur 5.11. zijn de combinaties van de voorkeurenplatsen éen en twee weergegeven.

Byjlage 18: 'Verdeling waardeoordelen per voorkeur en beoordelingswaarden' bevat de door de accountants gegeven waardeoordelen. De beoordelingen zijn gesorteerd naar zes subselecties "beheersingsmatregel op eerste dan wel tweede voorkeursplaats'. In het totaal zijn 978 beoordelingen verwerkt. De dubbeltelling is het gevolg van het feit dat zowel de eerste als de tweede voorkeursplaats zijn meegeno- 


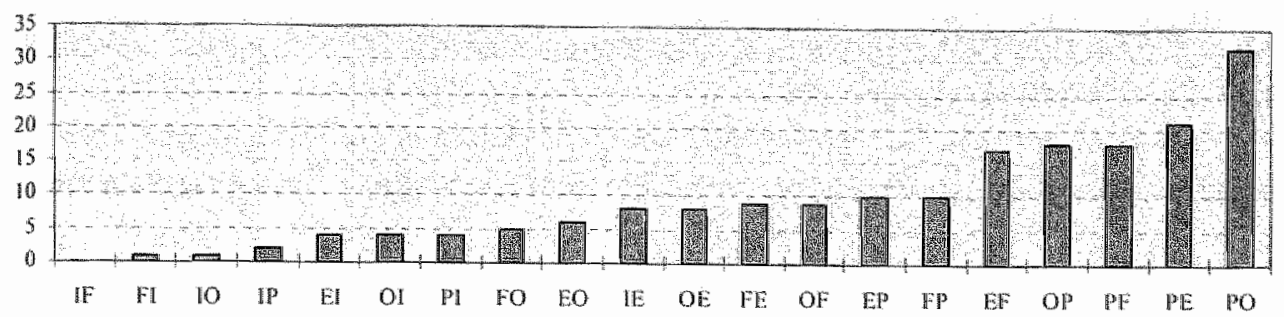

Figurir 5.11: Vardeling van de ranking wan de woorkeur in anal

men. Geen voorkeur is uitgesproken door een aantal accountants die 38 beoordelingen hebben uitgevoerd. Binnen de subselecties zijn de casusstellingen gegroepeerd in zes groepen, naar het antal soorten beheersingsmaatregelen dat in de casusstellingen voorkomt.

Met behulp van One-Way ANOVA zijn twee analyses als volgt uitgevoerd:

- In de eerste analyse, de ANOVA (1), zijn de beoordeelde casusstellingen per groep als uitgangspunt genomen. Binnen een groep casusstellingen met hetzelfde aantal soorten beheersingsmaatregelen is nagegaan of een significant verschil geconstateerd kon worden in de spreiding van de beoordelingen gegeven door de verschillende subselecties 'soort beheersingsmaatregel op eerste en tweede voorkeursplaats'. Op grond van hypothese 4 mag verwacht worden dat geen significant verschil in de spreiding van de gegeven beoordelingen geconstateerd zal worden. De hierbij behorende nulhypothese luidt: het niet afwijken van de varianties in de beoordeling van casusstellingen met hetzelfde aantal soorten beheersingsmaatregelen bij de verschillende subselecties 'soort beheersingsmaatregel op eerste en tweede voorkeursplaats";

- In de tweede anallyse, de ANOVA (2), zijn de subselecties "soort beheersingsmaatregel op eerste en tweede voorkeursplaats' als uitgangspunt genomen. Binnen een subselectie is nagegaan of een significant verschil geconstateerd kon worden in de spreiding van de beoordelingen gegeven ten aanzien van de groepen casusstellingen. Deze tweede analyse is niet rechtstreeks tuit hypothese 4 af te leiden. De doelstelling van deze analyses is vast te stellen of in de subselecties de beoordelingen van casusstellingen variëren indien het aantal soorten beheersingsmatregelen variëert. De hierbij behorende nulhypothese luidt: het niet afwijken van de varianties in de beoordeling van casusstellingen met een verschillend aantal soorten beheersingsmaatregelen binnen één subselectie "soort beheersingsmaatregel op eerste en tweede voorkeursplats'. 
Op basis van ANOVA (1) is geen significant verschil geconstateerd waardoor de nulhypothese niet kon worden verworpen.

Op basis wan ANOVA (2) zijn significante verschillen geconstateerd waardoor de malhypothese kon worden verworpen. De resultaten zijn weergegeven in figuur 5.12 .

\begin{tabular}{|c|c|c|c|}
\hline Aanlal & $\begin{array}{l}\text { AWOVA }(1) \\
\text { Factor = soont } \\
\text { beheersings- } \\
\text { molatregrel op eerste } \\
\text { en oweede } \\
\text { nowrkeursplants } \\
\mathrm{F}\end{array}$ & $\begin{array}{l}\text { Subselectiles soort } \\
\text { beheersingsmantregel } \\
\text { op eerste en tweede } \\
\text { roorkeursplarats }\end{array}$ & $\begin{array}{l}\text { ANOVA (2) } \\
\text { Factor = anntal } \\
\text { soorten } \\
\text { beheersings- } \\
\text { maatregelen } \\
\quad \text { F }\end{array}$ \\
\hline 5 beherringsmatregalen & 1.522 & $\begin{array}{l}\text { Procesbeheersing }(\mathrm{P}) \text {. } \\
319 \text { casusstellingen }\end{array}$ & $8.478 *$ \\
\hline 4 beheersingmadugeter & 0,113 & $\begin{array}{l}\text { Financiele beheersing }(F) \text {, } \\
201 \text { castustellingen }\end{array}$ & $2,493^{*}$ \\
\hline 3 behersingsmatregelen & 0,279 & $\begin{array}{l}\text { Organisatorische beheersing }(O) \text {. } \\
189 \text { axsustellingen }\end{array}$ & $5,842 *$ \\
\hline 2 beheersingmatregalen & 1,803 & $\begin{array}{l}\text { Informatiebehersing (I), } \\
63 \text { casusgtellingen }\end{array}$ & $3,842^{\star}$ \\
\hline 1 beheersingsmaatregel & 1,545 & $\begin{array}{l}\text { Prestatiebeheersing }(E) \text {, } \\
206 \text { casurstellingen }\end{array}$ & $4,376^{\star}$ \\
\hline Geen beheersings ruatregel & 0,538 & & \\
\hline
\end{tabular}

Figuur 5.12: ANOVA bij subsellecties 'soort beheersingsmaatregel op eerste dan wel tweede voorkeursplaats' (* significant $p \leq 0,05$ )

Tevens is met behulp van de Speaman correlatiecoëficiènt nagegaan of een correlaw tie bestaat binnen iedere subselectie 'soort beheersingsmaatregel' tussen de gegeven beoordelingen en het aantal soorten beheersingsmatregelen. De resultaten zijn in figuur 5.13 weergegeven.

Bij alle subselecties is een significante correlatie gevonden tussen de door de accountant gegeven beoordelingen gegroepeerd. naar "soort beheersingsmatregel op eerste en tweede voorkeursplaats' en het antal soorten beheersingsmaatregelen dat in de casusstelling is opgenomen.

In bijlage 18: 'Verdeling waardeoordelen per voorkeur en beoordelingswaarden' zijn per subselectie 'soort beheersingsmatregel op eerste en tweede voorkeursplaats' de beoordelingswaarden berekend zoals beschreven in paragraaf 4.4.4.2. Indien per subselectie 'soort beheersingsmaatregel op eerste en tweede voorkeursplaats' en 


\begin{tabular}{|c|c|c|}
\hline $\begin{array}{l}\text { Subselecties soort beheersingsumartregel } \\
\text { op eerste en tweede voorlkeursplaats }\end{array}$ & $\begin{array}{l}\text { Aantal } \\
\text { beoordellugien }\end{array}$ & $\begin{array}{l}\text { Spearman } \\
\text { correlatilecooficient } \\
r_{\mathrm{s}}\end{array}$ \\
\hline Procesbeluewsing $(P)$ & 319 casussellingen & $0,334 *$ \\
\hline Fimanciale beheersing (F) & 201 casusstellingen & $0,220 * *$ \\
\hline Organisatorische beheersing (O) & 189 casusstellingen & $0,348 * *$ \\
\hline Informatie beheersing (I) & 63 asusstellingen & $0,239 *$ \\
\hline Prestatie beheersing (E) & 206 casusstellngen & $0.293 *$ \\
\hline Totad: inclusice dubbelcelingen & 978 casusstellingen & $0,298^{*}$ \\
\hline Totalal: exclusief dubbeltellingen & 489 casusstellinge & \\
\hline
\end{tabular}

Fignar 5.13: Spearman correlatiecoefficient bij subselkacties 'soont belzersingsmatregelop eerste dan wel mwede woorkeursplats'

(** .01 level $(1-$ railed $)$ * .05 level $(1-$ tailled)

daarbinnen per groep casusstellingen met een verschillend aantal soorten beheersingsmaatregelen, gekeken wordt naar het verloop van de beoordelingswaarden ten opzichte van de totale beoordelingswarde van die subselectie, komt bij alle subselecties 'soort beheersingsmaatregel op eerste en tweede voorkeursplaats' een negatieve tendens in de waardering naar voren. Deze negatieve tendentie impliceert dat naarmate het aantal soorten beheersingsmaatregelen binnen een subselectie "soort beheersingsmaatregel op eerste en tweede voorkeursplaats' afneemt, ook de waarde van de beoordeling afneemt. In bijlage 18: "Verdeling waardeoordelen per voorkeur en beoordelingswaarden' is dit grafisch weergegeven.

In paragraaf 5.3 wordt nader ingegaan op het verschil tussen de door de accountants beoordeelde casusstellingen warin de door hen aangegeven voorkeuren zijn opgenomen, met de casusstellingen waarin deze niet zijn opgenomen.

\section{Conclusies}

Uit de ranking in belangrijkheid van de beheersingsmaatregelen, die de beoordelende accountants aangaven, blijkt, op basis van de voorkeurswaarde, een duidelijke voorkeur voor de beheersingsmaatregelen van de groep Procesbeheersing hetgeen in lijn ligt met de bevinding in paragraaf 5.2.3.1.. De beheersingsmaatregelen van de groep Informatiebeheersing worden duidelijk op de llatste plaats gezet. Over de andere drie groepen van beheersingsmaatregelen kan op basis van de voorkeurswaarde geen eenduidige ranking worden verkregen. Op grond van de berekende voorkeurswaarde kan dus geen eenduidige ranking van de beheersingsmaatregelen worden vastgesteld. 
Doordat geen significant verschil is geconstateerd tussen de varianties in de beoordelingen door accountants gegroepeerd naar de verschillende subselecties "soort beheersingsmaatregel op eerste en tweede voorkeursplaats', over casusstellingen met hetzelfde aantal soorten beheersingsmaatregelen, wordt de eerste nulhypothese gehandhaafd. Dit impliceert dat niet is vastgesteld dat de voorkeur van de accountant voor een soort beheersingsmatregel van invloed is op de variantie in de beoordelingswaarde van de casusstellingen. Op grond hiervan kan de vierde hypothese worden gehandhaafd.

Op basis van de tweede ANOVA analyse, de Spearman correlatiecoëfficiënt en het verloop in de beoordelingswaarden kan de conclusie worden getrokken dat een correlatie bestaat tussen de door de accountants gegeven warderingen gegroepeerd naar de verschillende subselecties 'soort beheersingsmaatregel op eerste en tweede voorkeursplaats' en het aantal beheersingsmaatregelen begrepen in een casusstelling. Op basis van deze uritkomsten kan de conclusie getrokken worden dat in de waarderingen van de accountants gegroepeerd naar de verschillende subselecties "soort beheersingsmaatregel op eerste en tweede voorkeursplaats' rekening gehouden wordt met het antal soorten beheersingsmaatregelen dat in een casusstelling is opgenomen.

\subsubsection{Consensus in oordeel, per cognitieve stijl}

Bij het formuleren wan de vijfde hypothese werd in hoofdstuk 3 aangegeven de aandacht meer te richten op besluitvaardigheid in plats van op het probleemoplossend vermogen. Daarbij werd gerefereerd aan cognitieve stijl en tolerantie voor ambiguiteit. Met betrekking tot de cognitieve stijl is een duidelijke indeling van accountants mogelijk. Ook is aangegeven dat "professional scepticism" zich ontwikkelt naarmate een accountant meer ervaring krijgt, waardoor aangesloten wordt op de tweede hypothese. Dit 'professional scepticism' wordt tot uitdrukking gebracht in de ambiguiteitwarde.

De vijfde hypothese valt uiteen in twee delen die als volgt waren geformuleerd:

H5a: Accontants behorende tor de twee MBTI warmemings-en oordeelswormingindex combinaties NT en ST zullen meer consensus vertonen dan de accontants behorende tot de warnemings-en oordeelsvormingindex combinaties $N F$ en SF.

H5b: Acountants behorevde tor de ambiguiteitswarde-groepen wan het merendeel van de accountants in vertegenuoordigd zijn zullen weer consensus vertonen dan de accoumtants vertegenwoordigd in de andere ambigutteitswarde-groepen. 


\subsubsection{Consensus in oordeel, per Myers-Briggs Type Indicator}

Voor het bepalen van de cognitieve stijl werd aan de beoordelende accountants gevraagd om de vragenlijsten van de Myers-Briggs Type Indicator (MBTI) in te vullen. Deze Indicator is gebaseerd op de theorieën van Jung. Alle 199 accountants hebben aan dat verzoek voldaan. Zoals in paragraaf 4.3.4.1 is aangegeven kent de MBTI vier sets van twee bij elkaar behorende indicatoren. Bij de beoordeling van de casusstellingen zijn vooral de waamemingsindex en de oordeelsvormingindex van belang ${ }^{12}$.

Door de indicatoren die bij een accountant het hoogst scoren te combineren ontstaan vier verschillende combinaties. In figuur 5.14. zijn weergegeven het aantal accountants behorende tot een van de combinaties, alsmede de hoeveelheid beoordeelde casusstellingen. Ook is de procentuele verdeling weergegeven.

\begin{tabular}{|c|c|c|c|c|c|}
\hline \multirow{2}{*}{$\begin{array}{l}\text { Waarnemings- } \\
\text { Oordeelsyornings- } \\
\text { ind } x\end{array}$} & \multicolumn{2}{|c|}{ Accountants } & \multicolumn{2}{|c|}{ Casusstellingen } & \multirow[b]{2}{*}{ geniddeld } \\
\hline & aantal & $8 \%$ & aantal & \#/ & \\
\hline NFE & 12 & $6,0,3 \%$ & 36 & $6,83 \%$ & 3,00 \\
\hline$S F$ & 20 & $10,05 \%$ & 32 & $6,07 \%$ & 1,60 \\
\hline $\mathbb{N T}$ & 59 & $29,65 \%$ & 170 & $32,26 \%$ & 2,88 \\
\hline ST & 108 & $54,29 \%$ & 289 & $54,84 \%$ & 2,68 \\
\hline Totaal & 199 & $100,00 \%$ & 527 & $100,00 \%$ & 2,65 \\
\hline
\end{tabular}

Figutur 5.14: Aantal accountants en casusstellingen per subselecties 'combinatie van warnemingmindex en oordee Isvormingindex"

De accountants ingedeeld in de types met de set ST indicatoren $(54,29 \%$ van de accountants) hebben $54,84 \%$ van de casusstellingen beoordeeld. De sets met ST en NT tezamen vertegenwoordigen $83,94 \%$ van de accountants; zij hebben $87,10 \%$ wan de casusstellingen beoordeeld.

Bijlage 19: "Verdeling waardeoordelen per MBTI type en beoordelingswarden' bevat de door de accountants gegeven waardeoordelen. Op grond van door de accountants ingevulde MBTI vragenlijst zijn de beoordeelde casusstellingen ingedeeld in de vier waarnemings- en oordeelsvormingindices. Binnen deze indices zijn de casusstellingen gegroepeerd in zes groepen, naar het aantal soorten beheersingsmatregelen dat in de casusstellingen is opgenomen.

Met behulp van One-Way ANOVA zijn twee analyses als volgt uitgevoerd:

- In de eerste analyse, de ANOVA (1), zijn de beoordeelde casusstellingen per groep als uitgangspunt genomen. Binnen een groep casusstellingen met hetzelfde aantal 
soorten beheersingsmaatregelen is nagegaan of een significant verschil geconstateerd kon worden in de spreiding van de beoordelingen gegeven door de verschillende subselecties 'combinatie van waarnemingsindex en oordeelsvormingindex". Op grond van hypothese 5 a mag verwacht worden dat een significant verschil in de spreiding van de gegeven beoordelingen geconstateerd zal worden tussen de MBTI warnemings- en oordeelsvormingindex combinaties NT en ST enerzijds en NF en SF anderzijds. De hierbij behorende nuihypothese luidt: het niet afwijken van de varianties in de beoordeling van casusstellingen met hetzelfde aantal soorten beheersingsmaatregelen bij de verschillende subselecties 'combinatie van waarnemingsindex en oordeelsvormingindex";

- In de tweede analyse, de ANOVA (2), zijn de subselecties 'combinatie van waarnemingsindex en oordeelsvormingindex' als uitgangspunt genomen. Binnen een subselectie is nagegaan of een significant verschil geconstateerd kon worden in de spreiding van de beoordelingen gegeven ten aanzien van de groepen casusstellingen. Deze tweede analyse is niet rechtstreeks uit hypothese $5 \mathrm{a}$ af te leiden. De doelstelling van deze analyses is vast te stellen of in de subselecties de beoordelingen van casusstellingen variëren indien het aantal soorten beheersingsmaatregelen varieert. De hierbij behorende nulhypothese luidt: het niet afwijken van de varianties in de beoordeling van casusstellingen met een verschillend aantal soorten beheersingsmaatregelen binnen één subselectie 'combinatie van waarnemingsindex en oordeelsvormingindex".

Op basis van ANOVA (1) is geen significant verschil geconstateerd waardoor de nulhypothese niet kon worden verworpen.

Op basis van ANOVA (2) zijn significante verschillen geconstateerd voor de subselecties NT en ST voor welke twee subselecties de nulhypothese kon worden verworpen. Aangezien geen significant verschil is geconstateerd bij de subselecties NF en SF kon voor die twee subselecties de nulhypothese niet worden verworpen ${ }^{13}$. Door het kleine aantal waarnemingen konden voor deze twee combinaties geen post-hoc vergelijkingen worden berekend. De resultaten zijn in fig 5.15 weergegeven.

Tevens is met behulp van de Speaman correlatiecoëfficiënt nagegaan of een correlatie bestat binnen iedere subselectie 'soort beheersingsmaatregel' tussen de gegeven beoordelingen en het antal soorten beheersingsmaatregelen. De resultaten zijn in figuur 5.16 weergegeven.

Voor alle subselecties is een significante correlatie gevonden tussen de door de accountant gegeven beoordelingen gegroepeerd naar "combinatie van waarne- 


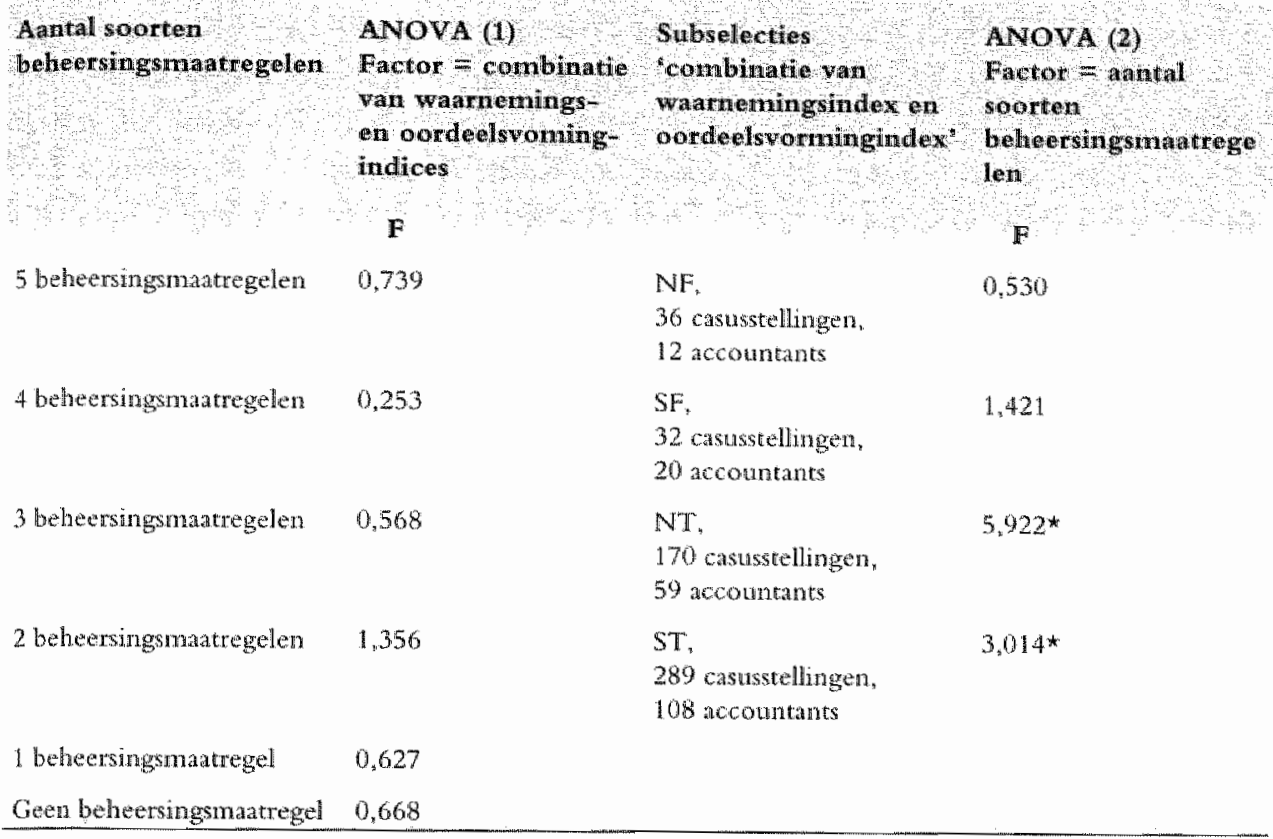

Figuur 5.15: ANOVA bij subselecties 'combinatie van wamemingsindex en oordeelsvormingindex" (*ignificart $p \leq 0,05$ )

\begin{tabular}{|c|c|c|}
\hline $\begin{array}{l}\text { Sunselecties combinatie van } \\
\text { warmemingsindex en } \\
\text { oordeelsvormungs index? }\end{array}$ & Aantal & $\begin{array}{l}\text { Spearmati } \\
\text { correlatidecowficient } \\
r_{s}\end{array}$ \\
\hline NF & 36 casusstellingen & $0 ; 295 *$ \\
\hline$S F$ & 32 casusstellingen & $0,407 *$ \\
\hline $\mathrm{NT}$ & 170 carusstellingen & $0,379 x *$ \\
\hline$S T$ & 289 casuserelingen & $0.241 *$ \\
\hline Totaal & $527 \mathrm{chusstellingen}$ & $0,30,3 * 4$ \\
\hline
\end{tabular}

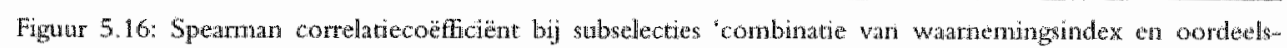
voriningindex"

(**.01 level $(1-$ tailed), * 05 level $(1-$ tailed $)$

mingsindex en oordeelsvormingindex' en het aantal soorten beheersingsmaatregelen dat in de casusstelling is opgenomen.

In bijlage 19: 'Verdeling waardeoordelen per MBTI rype en beoordelingswaarden' zijn per subselectie "combinatie van waarnemingsindex en oordeelsvormingindex" de beoordelingswaarden berekend zoals beschreven in paragraaf 4.4.4.2. Indien per subselectie 'combinatie van waarnemingsindex en oordeelsvormingindex' en daar- 
binnen per groep casusstellingen met een verschillend aantal soorten beheersingsmatregelen, gekeken wordt naar het verloop van de beoordelingswaarden ten opzichte van de totale beoordelingswarde van die subselectie, komt bij alle subselecties 'combinatie van warnemingsindex en oordeelswormingindex' een negatieve tendens in de waardering naar voren. Deze negatieve tendentie impliceert dat naarmate het aantal soorten beheersingsmaatregelen binnen een subselectie 'combinatie van waarnemingsindex en oordeelsvormingindex' afneemt, ook de waarde van de beoordeling afneemt. In bijlage 19: 'Verdeling waardeoordelen per MBTI type en beoordelingswaarden' is dit grafisch weergegeven.

In paragraaf 5.4. wordt nader ingegaan op de verdeling van de verschillende typen.

\section{Conclusies}

Doordat geen significant verschil is geconstateerd tussen de varianties in de beoordelingen door accountants gegroepeerd naar de verschillende subselecties 'combinatie van waarnemingsindex en oordeelsvormingindex", over casusstellingen met hetzelfde aantal soorten beheersingsmaatregelen, wordt de eerste nulhypothese gehandhaafd. Dit impliceert dat niet is vastgesteld dat de combinatie van waarnemingsindex en oordeelsvormingindex van invloed is op de variantie in de beoordelingswaarde van de casusstellingen. Daarmee is ook niet vastgesteld dat een frequentietoename van het voorkomen van accountants in een bepaald type, een positieve invloed heeft op de consensus. Op grond hiervan moet het eerste deel van de vijfde hypothese worden verworpen.

Wel kan op basis van de tweede ANOVA anallyse, de Spearman correlatiecoefficiënt en het verloop in de beoordelingswaarden de conclusie worden getrokken dat een correlatie bestaat tussen de door de accountants gegeven waarderingen gegroepeerd naar de subselecties 'combinaties van waarderingsindex en oordeelsvormingindex" NT en ST en het aantal beheersingsmaatregelen begrepen in een casusstelling. Op basis van deze uitkomsten kan de conclusie getrokken worden dat in de waarderingen van de accountants gegroepeerd naar deze twee subselecties rekening gehouden wordt met het aantal soorten beheersingsmaatregelen dat in een casusstelling is opgenomen. Doordat in de tweede ANOVA analyse geen significant verschil is geconstateerd voor de 'combinaties van wateringsindex en oordeelswormingindex' NT en ST, wordt deze conclusie alleen vanuit de tweede ANOVA analyse niet ondersteund. Het betreft hier wel een relatief klein aantal beoordelingen $(12,90 \%)$ uitgevoerd door een relatief klein aantal accountants $(16,06 \%)$.

\subsubsection{Consensus in oordeel, per ambigitteit}

Voor de bepaling van de tolerantie voor ambiguiteit is an de beoordelende accountants gevraagd om de AT-20 Scale vragenlijst van de MacDonald ambiguitteittest 
[MacDonald, 1970] in te vullen. Deze vragenlijst is gebaseerd op de Rydell-Rosen Ambiguity Tolerance Scale. Alle 199 accountants hebben aan dat verzoek voldaan. Zoals in paragraaf 4.3.4.2 is angegeven omvat de vragenlijst twintig vragen, waarbij een score, alleen in even waardes, gehaald kan worden tussen de -20 en +20 . Hierna wordt eerst ingegaan op de resultaten van de totale verdeling op basis van de gemeten ambiguïteit. De op basis van de ontvangen vragenlijsten berekende scores ${ }^{14}$, welke steeds met twee punten verspringen, kunnen als volgt grafisch worden weergegeven $^{15}$.

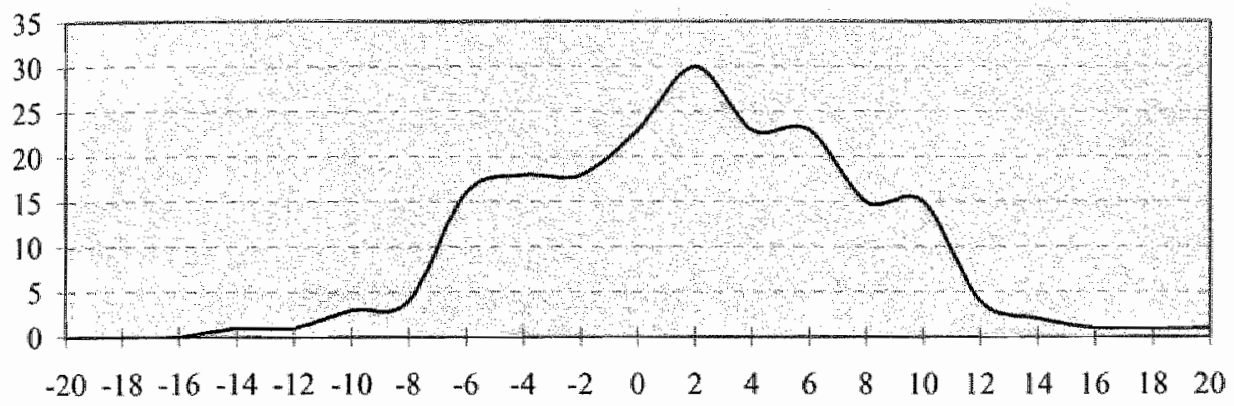

Eiguur 5.17: Werdeling van de ambiguiteitwatarde

Op basis van de theoretische beschouwing is in hoofdstuk 3 gesteld dat de mate van 'professional scepticism' zich ontwikkelt naarmate de accountant meer ervaring verkrijgt. Om een dergelijke ontwikkeling vast te kunnen stellen is, in analogie met de beoordelingswaarde in paragraaf 4.4.4.2. en voorkeurswaarde, de tolerantiewaarde berekend. Om deze berekening uit te kumnen voeren is aan iedere ambiguiteitswaarde een gewicht $(G)$ gegeven, startende met de ambiguiteitswaarde -20 met gewicht 1 en oplopend tot de ambiguïteitsgwaarde +20 met gewicht 21 .

De tolerantiewaarde wordt als volgt berekend:

$$
T W=\frac{\left.\sum_{m=-2 i n}^{a C C a u} \times \text { Gaw }\right)}{A C C}
$$

- $\mathrm{TW}=$ tolerantiewaarde

- $\mathrm{aw}=$ ambiguiteitswaarde

- $\mathrm{ACC}=$ aantal Accountants

- Gaw = gewicht per ambiguitteitswaarde

De tolerantiewaarde zou volgens de theoretische beschouwingen moeten variëren bij het variëren van de jaren werkervaring. In figuur 5.18 is het procentuele verloop van de tolerantiewaarde per ervaringsjaar ten opzichte van de tolerantiewaarde van 
de totale selectie ( $=0 \%$ lijn) weergegeven. Op basis van de logaritmische trendanalyse, zoals weergegeven in figuur 5.18 , kan de conclusie getrokken worden dat naarmate meer ervaring wordt opgedaan de tolerantiewaarde en daarmee de ambiguiteitswaarde richting de negatieve kant verschuift. Naar mate de ervaringsjaren toenemen neent de tolerantie voor ambiguë situaties dus af.

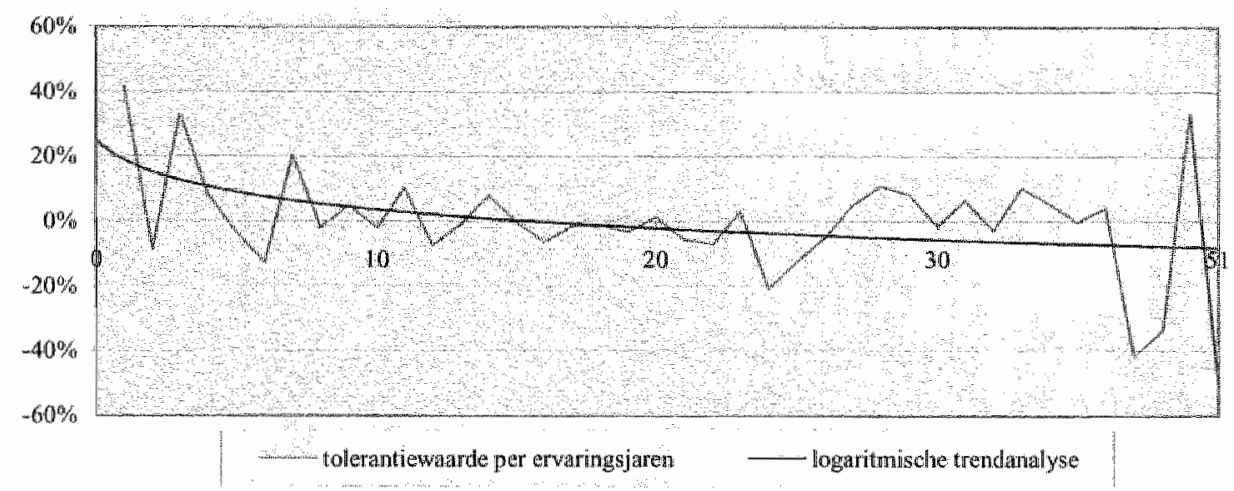

Figunt 5,18: Tolerantiewarde per ervaringsjaar

Bijlage 20: "Verdeling waardeoordelen per ambiguiteitwaarde en beoordelingswaarden' bevat de door de accountants gegeven waardeoordelen. Op grond van door de accountants ingevulde vragenlijst $z i j n$ de casusstellingen gegroepeerd in vier subselecties. Binnen de subselecties zijn de casusstellingen gegroepeerd in zes groepen, naar het aantal soorten beheersingsmaatregelen dat in de casusstellingen is opgenomen.

Met behulp van One-Way ANOVA zijn twee analyses als volgt uitgevoerd:

- In de eerste analyse, de ANOVA (1), zijn de beoordeelde casusstellingen per groep als uitgangspunt genomen. Binnen een groep casusstellingen met hetzelfde aantal soorten beheersingsmaatregelen is nagegaan of een significant verschil geconstateerd kon worden in de spreiding van de beoordelingen gegeven door de verschillende subselecties 'ambiguiteitsgroep'. Op grond van hypothese $5 \mathrm{~b}$ mag verwacht worden dat een significant verschil in de spreiding van de gegeven beoordelingen geconstateerd zal worden tussen de ambiguiiteitsgroepen -6 tot en met 0 en 2 tot en met 6 enerzijds en -20 tot en met -8 en 8 tot en met 20 anderzijds. De hierbij behorende nulhypothese luidt: het niet afwijken van de varianties in de beoordeling van casusstellingen met hetzelfde aantal soorten beheersingsmaatregelen bij de verschillende subselecties 'ambiguiteitsgroep'; 
- In de tweede analyse, de ANOVA (2), zijn de subselecties 'ambiguiteitsgroep' als uitgangspunt genomen. Binnen een subselectie is nagegaan of een significant verschil geconstateerd kon worden in de spreiding van de beoordelingen gegeven ten aanzien van de groepen casusstellingen. Deze tweede analyse is niet rechtstreeks uit hypothese $5 b$ af te leiden. De doelstelling van deze analyses is vast te stellen of in de subselecties de beoordelingen van casusstellingen variëren indien het aantal soorten beheersingsmaatregelen varieert. De hierbij behorende nulhypothese luidt: het niet afwijken van de varianties in de beoordeling van casusstellingen met een verschillend aantal soorten beheersingsmatregelen binnen één subselectie 'ambiguiteitsgroep'.

Op basis van ANOVA (1) is geen significant verschil geconstateerd waardoor de nulhypothese niet kon worden verworpen.

Op basis van ANOVA (2) zijn voor een drietal ambiguiteitsgroepen significante verschillen geconstateerd waardoor voor die groepen de nulhypothese kon worden verworpen. De uitzondering betrof de ambiguïteitsgroep -20 tot en met -8 waartoe slechts 9 accountants behoorden ${ }^{16}$. Door het kleine aantal waarnemingen kon voor deze ambiguiteitsgroep geen post-hoc vergelijking worden berekend. De resultaten zijn in figuur 5.19 weergegeven.

\begin{tabular}{|c|c|c|c|}
\hline Aantal soorten & $\begin{array}{l}\text { ANOVA }(1) \\
\text { Factor }= \\
\text { ambiguiteitsgroep } \\
\text { F }\end{array}$ & $\begin{array}{l}\text { Subselecties } \\
\text { aumbiguiteits groep }\end{array}$ & $\begin{array}{l}\text { ANOVA ( }) \\
\text { Factor }=\text { aantal } \\
\text { soonten } \\
\text { beheersings- } \\
\text { matregelen } \\
\mathrm{F}\end{array}$ \\
\hline 5 behersingsrnatragelen & 0,561 & $\begin{array}{l}-20 \text { tot en met }-8 \text {, } \\
20 \text { casusstellingen. } \\
9 \text { accountants }\end{array}$ & 0,6 ing \\
\hline 4 beheersingsmatregelen & 1,478 & $\begin{array}{l}-6 \text { tot un mat } 0, \\
210 \text { casustellingen, } \\
75 \text { accountants }\end{array}$ & $4.596 *$ \\
\hline 3 beheersingsmaatregelen & 0,392 & $\begin{array}{l}2 \text { tot en met } 6 \text {, } \\
209 \text { casustellingen. } \\
76 \text { accountarts }\end{array}$ & $4,015 *$ \\
\hline 2 beher ringsmatatregelen & 1.624 & $\begin{array}{l}8 \text { tolt en met } 20 \text {, } \\
88 \text { asusstellingen, } \\
39 \text { accountants }\end{array}$ & $3,888 *$ \\
\hline 1 beheersingsmaatregel & 0.744 & & \\
\hline Geen beheersingsmatregel & 0,983 & & \\
\hline
\end{tabular}

Figuer 5.19. ANOVA bij subselecties 'ambiguiteitsgroep' (* significant $\mathrm{p} \leq 0,05$ ) 
Tevens is met behulp van de Spearman correlatiecoëfficiënt nagegaan of een correlatie bestaat binnen iedere subselectie "ambiguiteitsgroep" tussen de gegeven beoordelingen en het aantal soorten beheersingsmaatregelen. De resultaten zijn in figuur 5.20 weergegeven.

\section{Sulbedecties ambiguitel ts groep? \\ -20 coten met -8 \\ -6 tot en thet 0 \\ 2 tot en met 6 \\ 8. tot en met 20 \\ Total}

\section{Anatal}

beodrdelingen

20 castustellingen

210 casustellingary

209 casusstellingern

88 casusstellingev

527 casusctilingen

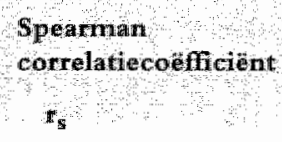

0,263

0,274 *

$0,276 *$

$0,419 k$

0,303

Figur 5.20: Spearnan correlatiecoêfficiërnt bij stbselecties "ambiguïteitsgroep"

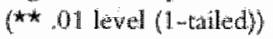

In bijlage 20: 'Verdeling waardeoordelen per ambiguiteitwaarde en beoordelingswaarden' zijn per subselectie 'ambiguïteitsgroep' de beoordelingswaardlen berekend zoals beschreven in paragraaf 4.4.4.2. Indien per subselectie 'ambiguïteitsgroep' en daarbinnen per groep casusstellingen met een verschillend aantal soorten beheersingsmaatregelen, gekeken wordt naar het verloop van de beoordelingswaarden ten opzichte van de totale beoordelingswaarde van die subselectie, komt bij alle subselecties 'ambiguitteitsgroep' een negatieve tendens in de waardering naar voren. Deze negatieve tendentie impliceert dat naarmate het aantal soorten beheersingsmaatregelen binnen een subselectie 'ambiguitteitsgroep' afneemt, ook de waarde van de beoordeling afneemt. In bijlage 20: "Verdeling waardeoordelen per ambiguiiteitswaarde en beoordelingswaarden' is dit grafisch weergegeven.

Als de totale beoordelingswaarde van de verschillende subselecties 'ambiguiteitsgroep" met elkaar worden vergeleken blijkt dat naarmate de tolerantie voor ambiguiteit toeneemt, hetgeen inhoudt dat beter omgegaan kan worden met inconsistenties en contradicties in de informatie, negatiever wordt gereageerd op de voorgelegde te beoordelen casusstellingen:

- ambiguiteitsgroep -20 tot en met -8 met een totale beoordelingswaarde van: 5,3000 ;

- ambiguiiteitswaarde -6 tot en met 0 met een totale beoordelingswaarde van: 4,8000;

- ambiguiteitswaarde 2 tot en met 6 met een totale beoordelingswaarde van: 4,7656 ; 
- ambiguiteitswaarde 8 tot en met 20 met een totale beoordelingswaarde van: $4,5909$.

\section{Conclusies}

Doordat geen significant verschil is geconstateerd tussen de varianties in de beoordelingen door accountants gegroepeerd naar de verschillende subselecties 'ambiguïteitsgroep", over casusstellingen met hetzelfde aantal soorten beheersingsmaatregelen, wordt de eerste nulhypothese gehandhaafd. Dit impliceert dat nit is vastgesteld dat de ambigüteit van invloed is op de variantie in de beoordelingswaarde van de casusstellingen. Daarmee is ook niet vastgesteld dat een frequentietoename van het voorkomen van accountants in een bepaald ambiguiteitsgroep, een positieve invloed heeft op de consensus. Op grond hiervan moet het tweede deel van de vijfde hypothese worden verworpen.

Wel kan op basis van de tweede ANOVA analyse, de Spearman correlatiecoëfficiënt en het verloop in de beoordelingswaarden de conclusie worden getrokken dat een correlatie bestaat tussen de door de accountants gegeven warderingen gegroepeerd naar de verschillende subselecties 'ambiguiteitsgroep' en het aantal beheersingsmaatregelen begrepen in een casusstelling. Op basis van deze uitkomsten kan de conclusie getrokken worden dat in de waarderingen van de accountants gegroepeerd naar de verschillende subselecties 'ambiguiteitsgroep' rekening gehouden wordt met het aantal soorten beheersingsmaatregelen dat in een casusstelling is opgenomen. Uitzondering hierop betrof de ambiguiteitsgroep -20 tot en met -8 , waarin minder dan $1 \%$ van de accountants is vertegenwoordigd.

\subsubsection{Samenvatting 'Consensus in oordeel'}

In deze paragraaf zijn de conclusies samengevat weergegeven voor zover zij betrekking hebben op de hypotheses van de eerste onderzoeksvraag. Deze cerste onderzoeksvraag heeft betrekking op de consensus tussen de oordelen van alle in het onderzoek betrokken accountants. Om de spreiding in de gegeven waarderingen inzichtelijk te maken is gebruik gemaakt van een consensuswaarde en een beoordelingswaarde. Met behulp van de variantie-analyses One-Way ANOVA is vastgesteld in hoeverre sprake is van significante verschillen in de waarderingen binnen de selecties.

Voorts is op basis van een tweede ANOVA analyse, de Spearman correlatiecoêfficient en het verloop in de beoordelingswarden binnen de subselecties nagegaan of een correlatie bestaat tussen de door de accountants gegeven waarderingen gegroepeerd naar de verschillende subselecties en het aantal beheersingsmatregelen begrepen in een casusstelling. 
In het vervolg van deze paragraaf wordt eerst een beschrijvende samenvatting gegewen van de consensus in de oordelen. Daarna wordt een samenvatting gegeven van de resultaten van de One-Way ANOVA-tests. Afgesloten wordt met een samenvatting van de verschuivingen in de gegeven waarderingen berekend met de Speamian's correlatiecoefficiẻnt.

\subsubsection{Samenwatting "Consensus in oordeel", beschrivend}

In het onderzoek hebben 199 accountants 527 oordelen gegeven over 32 verschillende casusstellingen. Om inzicht te verkrijgen in thet niveau van gegeven gelijkluidende oordelen", ofwel de "consensus' van de beoordelaars bij de beoordeling van de versichillende casusstellingen, werd voor de 527 gegeven oordelen consensuswarrden berekend. Deze consensuswaarde geeft weer de procentuele verdeling van de door de accountants gegeven waarderingen van een casusstelling. Doordat door de beoordelende accountants steeds verschillende casusstellingen zijn beoordeed geeft dit percentage tevens weer het percentage accountants die eenzelfde waardering hebben gegeven an een casusstelling.

Ook werden twee consensusindices berekend:

- De 'consensusindex gericht op casusstellingen' aangevend het percentage casusstellingen met een consensuswaarde op één van de zeven waarderingsmogelijkheden groter dan wel gelijk aan een consensus meetpunt.

- De "consensusindex gericht op beoordelingen" aangevend het percentage beoordelingen met een consensuswaarde op één van de zeven waarderingsmogelijkheden groter dan wel gelijk aan een consensus meetpunt.

Het Consensus Meetpunt is een flexibel in te stellen percentage.

Bij een Consensus Meetpunt van $50 \%$ bedraagt de consensusindex gericht op de casustellingen $9,38 \%$ en de consensusindex gericht op de beordelingen $5,31 \%$.

Dit impliceert dat door nimimal 100 accountants (50\% van 199 accountants) een gelijkluidende wardering is gegeven bij $9,38 \%$ van de casusstellingen, zijnde 3 van de 32 casusstellingen, warbij $5,31 \%$ van de beoordelingen, zijnde 28 van de 527 beoordelingen, waren betrokken.

Twee van deze drie casusstellingen betroffen de twee uiterste casusstellingen; de ene met alle beheersingsmatregelen en de andere zonder enige beheersingsmaatregel.

Bij de beoordeling van de casusstellingen konden de beoordelaars kiezen uit 7 verschillende waarderingsmogeljkheden, van 'Uitstekend' tot 'Zeer slecht'. Gemiddeld werd per casusstelling 4,875 verschillende waarderingsmogelijkheden gegeven. Bij zestien casusstellingen met in total 255 beoordelingen werden vijf van de zeven verschillende waarderingsmogelijkheden gebruikt.

Verder blijkt dat bij iedere casusstelling de warderingsmogelijkheid 'Goed' is gege- 
ven. Bij 29 van de 32 casusstellingen komt de range van de waarderingsmogelijkheden 'Zeer Goed', 'Goed' en 'Voldoende' voor.

Gelet op de lage consensusindices kan niet geconcludeerd worden dat aantoonbaar is gemaakt dat sprake is van consensus tussen de oordelen van accountants aangaande de toereikendheid van administratief-organisatorische processen. Hierdoor kan geen ondersteuning gegeven worden aan de stelling van Meservy, Bailey en Johnson [1986] dat de consensus van de beoordelingen van accountants het gemis van een normatief model van beheersingsmaatregelen kan opvangen.

\subsubsection{Samenvatting 'Consensus in oordeel', ANOVA (1)}

Om vast te stellen in hoeverre sprake is van significante verschillen in de waarderingen is gebruik gemaakt van de One-Way ANOVA variantie-analyse. Deze berekeningen zijn gemaakt voor zes subselecties van de onderzoekspopulatie, te weten voor:

- jaren werkervaring;

- soort beheersingsmaatregel;

- voorkompercentage;

- soort beheersingsmaatregel op eerste en tweede voorkeursplats;

- combinatie van waarnemingsindex en oordeelsvormingindex;

- ambiguiteitsgroep.

Met behulp van One-Way ANOVA is een eerste analyse als volgt uitgevoerd:

- In de eerste analyse, de ANOVA (1), zijn de beoordeelde casusstellingen per groep als uitgangspunt genomen. Binnen een groep casusstellingen met hetzelfde aantal soorten beheersingsmaatregelen is nagegaan of een significant verschil geconstateerd kon worden in de spreiding van de beoordelingen gegeven door de verschillende 'subselecties van de onderzoekspopulatie'.

Op basis van de uitkomsten van ANOVA (1), bij een $p \leq 0,05$, is geen significant ver-schil geconstateerd in de spreiding van de beoordelingen gegeven door de verschillende 'subselecties van de onderzoekspoptulatie'. Dit impliceert dat niet is vastgesteld dat een van de variabelen van invloed is op de variantie in de beoordelingswaarde van de casusstellingen.

\subsubsection{Samenuatting 'Consensus in oordeel', ANOVA (2), Spearman's correlatie} Met behulp van One-Way ANOVA is een tweede analyse als volgt uitgevoerd:

- In de tweede analyse, de ANOVA (2), zijn de 'subselectie van de onderzoekspopulatie' als uitgangspunt genomen. Binnen een subselectie is nagegaan of een significant verschil geconstateerd kon worden in de spreiding van de beoordle- 
lingen gegeven ten aanzien van de groepen casusstellingen. Deze tweede analyse is niet rechtstreeks uit de hypotheses af te leiden. De doelstelling van deze analyses is vast te stellen of in de 'subselectie van de onderzoekspopulatie' de beoordelingen van casusstellingen variëren indien het aantal soorten beheersingsmaatregelen varieert.

Op basis van de uitkomsten van ANOVA (2), bij een $\mathrm{p} \leq 0,05$, zijn significante verschillen geconstateerd in de spreiding van de beoordelingen gegeven ten aanzien van de groepen casusstellingen. Samengenomen met de uitkomsten van de Spearman correlatiecoëfficiënt en het verloop in de beoordelingswaarden kan de conclusie worden getrokken dat een correlatie bestaat tussen de door de accountants gegeven waarderingen gegroepeerd naar de verschillende 'subselecties van de onderzoekspopulatie' en het aantal beheersingsmaatregelen begrepen in een casusstelling. Op basis van deze uitkomsten kan de conclusie getrokken worden dat in de waarderingen van de accountants gegroepeerd naar de verschillende 'subselectie van de onderzoekspopulatie' rekening gehouden wordt met het aantal soorten beheersingsmatregelen dat in een casusstelling is opgenomen.

\section{3. 'Voorkeur' van de accountant}

In deze paragraaf zijn de observaties, bevindingen en conclusies weergegeven voor zover betrekking hebbende op de tweede onderzoeksvraag. Zoals gesteld in hoofdstuk 1 betreft de tweede onderzoeksvraag het evaluatiecriterium voorkeur volgens het framework van Solomon en Shields [1995] en dat van. Ashton [1983]. Om deze vraagstelling te kumnen beantwoorden is in hoofdstuk 3 een hypothese ontwikkeld. Daarin is verondersteld dat de accountant bij zijn werkzaamheden gebruik maakt van het zogenaamde "episodic procedural knowledge"17 kennissegment en dat hij dit kennissegment, bij het in stand houden van zijn prototypisch mentaal model, zal bijstellen. In voorgaande hoofdstukken werd aangegeven dat het 'episodic procedural knowledge" kennissegment gebaseerd is op de ervaringen van de individuele accountant waardoor het een structurerende werking heeft op de kennis. Immers het prototypische mentaal model is een gestructureerde weergave van de door instructie, ervaring en aanleg opgebouwde kennis voor de uitvoering van een specifieke tak. Anders gezegd, het prototypisch mentaal model wordt gezien als de resultante van het gehele proces van taakgerichte kennisopbouw en kennisstructurering [Rosch, 1978; Wright, 1977].

De zesde hypothese was als volgt geformuleerd:

H6: Accountants zullen in hun oordelen meer consensus vertonen naarmate beheersingsmaatregelen voorkomen uraraan zij de 'poorkeur' geven. 
Zoals bij het formuleren van de hypothese in hoofdstuk 3 is aangegeven moet het onderzoeksmateriaal worden verdeeld op basis van de weerspiegeling van de door de accountant gegeven voorkeur en de in de casusstelling opgenomen beheersingsmaatregelen. In dit onderzoek zijn betrokken, overeenkomstig het gestelde in paragraf 5.2.4, de door de accountants op de eerste danwel tweede plats gestelde beheersingsmaatregelen als zijnde de 'voorkeur' van de accountant ${ }^{18}$.

Bijlage 21: "Verdeling waardeoordelen per mate van weerspiegeling en beoordelingswaarden' bevat de door de accountants gegeven waardeoordelen. De beoordelingen zijn gesorteerd naar drie subselecties 'mate van weerspiegeling':

1. 'mate van weerspiegeling $=1$ e en 2 e voorkeur' $(=2)$, zijnde de subselectie waarbij in de te beoordelen casusstelling zowel de door de beoordelende accountant op de eerste als op de tweede plats gestelde soort beheersingsmaatregel is opgenomen;

2. 'mate van weerspiegeling $=1$ e of $2 \mathrm{e}$ voorkeur' $(=1)$, zijnde de subselectie warbij in de te beoordelen casusstelling of de door de beoordelende accountant op de eerste plaats dan wel op de tweede plaats gestelde soort beheersingsmattregel is opgenomen;

3. 'mate van weerspiegeling = geen voorkeur' $(=0)$, zijnde de subselectie waarbij in de te beoordelen casusstelling geen soort beheersingsmaatregel is opgenomen die door de accountant op de eerste plaats dan wel de op de tweede plaats is gesteld.

Binnen de subselecties zijn de casusstellingen gegroepeerd in zes groepen, naar het aantal soorten beheersingsmaatregelen dat in de casusstellingen is opgenomen.

Per subselectie is de beoordelingswaarde berekend. Als de beoordelingswaarden tegen elkaar worden afgezet blijkt dat bij iedere groep casusstellingen de beoordelingswaarde van de subselectie 'mate van weerspiegeling = 1e en 2e voorkeur' hoger ligt dan de twee andere subselecties. Van de twee andere subselecties liggen de beoordelingswaarden van de subselectie "mate van weerspiegeling $=1 \mathrm{e}$ of $2 \mathrm{e}$ voorkeur' hoger dan die van de subselectie 'mate van weerspiegeling = geen voorkeur'. In figuur 5.21 is dit grafisch weergegeven.

Als cen zelfde vergelijking wordt gemaakt op basis van de verdeling van de gegeven waardeoordelen met $^{19}$ en zonder voorkeur ${ }^{20}$ blijkt, zoals weergegeven in figuur 5.22 , een duidelijke trend. De beoordelingswaarden van de beoordeelde casusstellingen waarin beheersingsmaatregelen zijn opgenomen, die behoren tot de eerste of tweede voorkeur van de beoordelende accountant, liggen in alle gevallen hoger dan de beoordelingswaarden van de beoordeelde casusstellingen waarin geen beheersingsmaatregelen zijn opgenomen die tot die voorkeur behoren. Opvallend is even- 


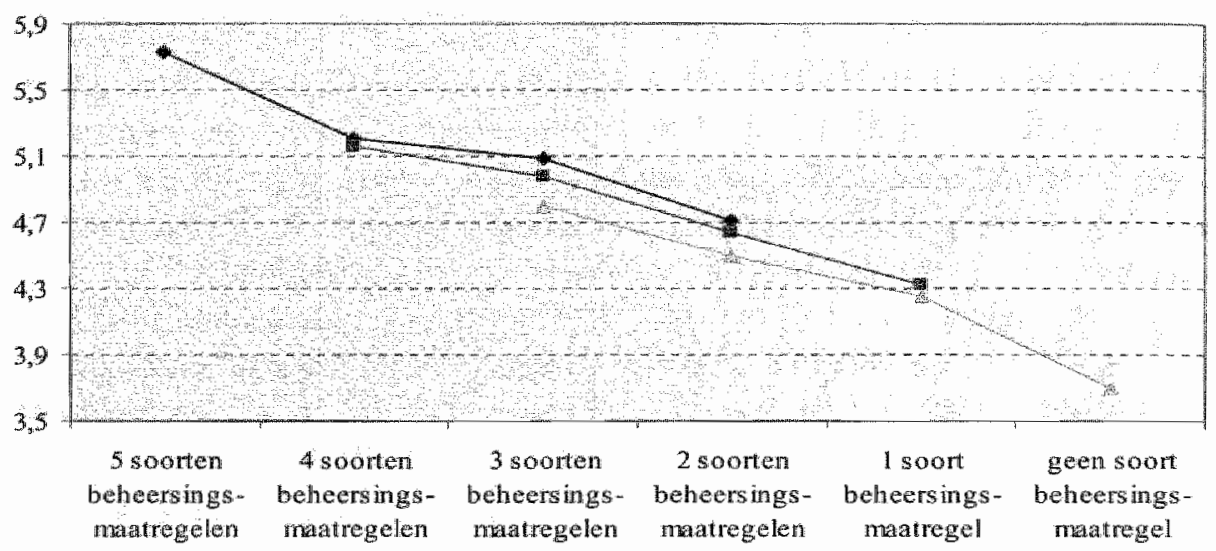
- Mate wan weersplegeling $=2$
Mate van werspiegeling $=0$

Figutr 5.21 . Vergelijking beoondelingswarde bij casusstellingen in relattie tot mate van weerspiegeling

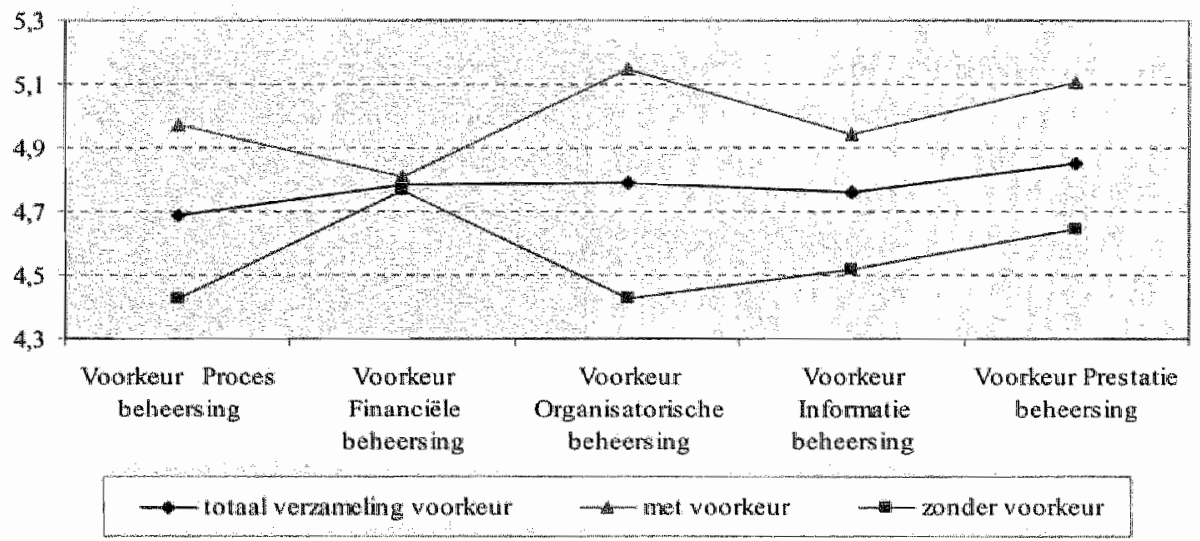

Figum 5.22: Vergelijking beoordelingwaarde bij casurstellingen in relatie tot voorkour

wel het kleine verschil van $0,91 \%$ bij de groep met voorkeur voor de financiële beheersing.

Met behulp van One-Way ANOVA zijn twee analyses als volgt uitgevoerd:

- In de eerste analyse, de ANOVA (1), zijn de beoordeelde casusstellingen per groep als uitgangspunt genomen. Binnen een groep casusstellingen met hetzelfde aantal soorten beheersingsmaatregelen is nagegaan of een significant verschil geconstateerd kon worden in de spreiding van de beoordelingen gegeven door de verschillende subselecties 'mate van weerspiegeling". Op grond van hypothese 6 mag 
verwacht worden dat een significant verschil in de spreiding van de gegeven beoordelingen geconstateerd zal worden. De hierbij behorende nullhypothese luidt: het niet afwijken van de varianties in de beoordeling van casusstellingen met hetzelfde aantal soorten beheersingsmaatregelen bij de verschillende subselecties 'mate van weerspiegeling';

- In de tweede analyse, de ANOVA (2), zijn de subselecties 'mate van weerspiegeling" als uitgangspunt genomen. Binnen een subselectie is nagegaan of een significant verschil geconstateerd kon worden in de spreiding van de beoordelingen gegeven ten aanzien van de groepen casusstellingen. Deze tweede analyse is niet rechtstreeks uit hypothese 6 af te leiden. De doelstelling van deze analyses is vast te stellen of in de subselecties de beoordelingen van casusstellingen variëren indien het aantal soorten beheersingsmaatregelen varieert. De hierbij behorende nulhypothese luidt: het niet afwijken van de varianties in de beoordeling van casusstellingen met een verschillend aantal soorten beheersingsmaatregelen binnen één subselectie 'mate van weerspiegeling'.

Op basis van ANOVA (1) is geen significant verschil geconstateerd waardoor de nulhypothese niet kon worden verworpen.

Op basis van ANOVA (2) zijn significante verschillen geconstateerd waardoor de nulhypothese kon worden verworpen. De resultaten zijn weergegeven in figuur 5.23 .

\begin{tabular}{|c|c|c|c|}
\hline Anntal soorten & $\operatorname{ANONA}(1)$ & Subselecties mate wan & ANONA (2) \\
\hline beheetsingsmanatregelen & $\begin{array}{l}\text { Facror }=\text { groep } \\
\text { met mate van } \\
\text { weersplegeling } \\
\text { F }\end{array}$ & weerspiegeling ? & $\begin{array}{l}\text { Factor = antal } \\
\text { soorten } \\
\text { beheersings- } \\
\text { thantregelen } \\
\text { f }\end{array}$ \\
\hline 4 behessingsmatregelen & 0,180 & $\begin{array}{l}\text { 1e en } 2 \text { e kus anwezig an } \\
\text { casustelling }\end{array}$ & $2,910 *$ \\
\hline 3 behersingsmatregelen & 0,437 & $\begin{array}{l}\text { 1e of } 2 \text { e keus anwexis in } \\
\text { casustelling }\end{array}$ & $2,865 *$ \\
\hline 2 beheersingsmatregelen & 0,212 & 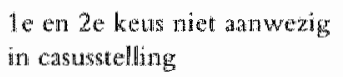 & $3,485 *$ \\
\hline 1 belheersingsmatregel & $0,0,4$ & & \\
\hline
\end{tabular}

Fignu 5.23: ANOWA bij subselecties "mate van weerspiegeling" (* siginificant $\leq 0,05$ )

Tevens is met behulp van de Spearman correlatiecoëfficiënt nagegaan of een correlatie bestaat tussen het in de casusstellingen voorkomen van de door de accountant 
aangegeven voorketuren voor de beheersingsmaatregelen en de door de accountant gegeven oordelen. Uitgaande van de hiervoor weergegeven bevindingen aangaande de beoordelingswaarden van casusstellingen met en zonder beheersingsmaatregelen, conform de voorkeur van de accountant en de in paragraaf 5.2.4. gedane bevindingen, mag een correlatie worden verwacht, uitgaande van de beoordelingen van casusstellingen waarin minimaal éen wan de twee voorkeuren is vertegenwoordigd.

De Spearman's correlatiecoëfficiënt bevestigt het bestaan van de correlatie die als significant wordt gezien (01 level, 1-tailed) en een warde kent van 0,235.

Ten behoeve van de hypothese 6 zijn de onderzoeksgegevens ${ }^{21}$ eveneens met behulp van een box-plot diagram geanalyseerd waarbij de interkwartielafstand ${ }^{22}$ inzichtelijk is gemaakt.

Dit geeft het wolgende beeld:

\section{Mate yan weerspiegoling}

Eerste en twede woorketir an wezth

Eerste of rwede voorkeur anwezig

Gewn wan beide voorkeuren anwezig

\section{Interkwartielafistand}

Zeer goed tot en met Goed

Zeer goed tot en met Voldoende

Goed tot en met Onvoldoende

Figuur 5.24: Interkwarticlafstanden bij box-plat

Uit figuur 5.24 blijkt dat de spreiding in de oordelen binnen de subselectie 'mate van weerspiegeling $=1$ e en $2 \mathrm{e}$ voorkeur' kleiner is dan die van de subselectie 'mate van weerspiegeling $=1$ e of $2 \mathrm{e}$ voorkeur'. De spreiding in de oordelen binnen de subselectie 'mate van weerspiegeling $=1$ e of $2 \mathrm{e}$ voorkeur' is evenwel even groot als die binnen de subselectie 'mate van weerspiegeling $=0$ '.

De waarderingen in de twee subselecties met casusstellingen waarin de voorkeur van de beoordelende accountant is vertegenwoordigd zijn positiever dan de subselectie met casusstellingen waarin de voorkeur van de accountant niet is vertegenwoordigd.

\section{Conclusies}

Doordat geen significant verschil is geconstateerd tussen de varianties in de beoordelingen door accountants gegroepeerd naar de verschillende subselecties 'mate van weerspiegeling", over casusstellingen met hetzelfde aantal soorten beheersingsmaatregelen, wordt de eerste nulhypothese gehandhaafd. Dit impliceert dat niet is vastgesteld dat de 'mate van weerspiegeling' van invloed is op de variantie in de beoordelingswaarde van de casusstellingen. Op grond hiervan moet de zesde hypothese worden verworpen.

Wel kan op basis van de tweede ANOVA analyse, de Spearman correlatiecoëfficiënt en de box-plot diagram de conclusie worden getrokken dat een correlatie bestaat tus- 
sen de door de accountants gegeven waarderingen gegroepeerd naar de verschillende subselecties 'mate van weerspiegeling' en het aantal beheersingsmaatregelen begrepen in een casusstelling. Op basis van deze uitkomsten kan de conclusie getrokken worden dat in de waarderingen van de accountants gegroepeerd naar de verschillende subselecties 'mate van weerspiegeling' rekening gehouden wordt met het aantal soorten beheersingsmaatregelen dat in een casusstelling is opgenomen.

Voorts is geconstateerd dat de door de accountants gegeven oordelen over casusstellingen met daarin opgenomen beheersingsmaatregelen overeenkomstig de eerste of tweede voorkeur van de beoordelende accountant, positiever zijn dan bij casusstellingen waarin geen van de beheersingsmaatregelen zijn opgenomen waarvoor de accountant een voorkeur heeft uitgesproken.

\subsection{Het psychologische profiel van de accountant.}

In deze paragraaf zijn de observaties, bevindingen en conclusies weergegeven die betrekking hebben op de derde onderzoeksvraag. Zoals gesteld in hoofdstuk 1 betreft de derde onderzoeksvraag naar de veranderingen in de eigenschappen van de accountant, die het gevolg zijn van de ontwikkelingen in de controlefilosofie binnen de accountantskantoren en van de ontwikkelingen binnen het corporate governance-gedachtegoed. Bij het onderzoek naar eventuele veranderingen in de eigenschappen van de accountant is gebruik gemaakt van de Myers-Briggs Type Indica$\operatorname{tor}^{23}$. De Myers-Briggs Type Indicator is gebaseerd op de theorie van Jung. Deze theorie benadrukt dat een persoonlijkheid gevormd wordt door de interactie van de karaktertrekken [Bringhurst, 2001; Wheeler, 2001]. Jung heeft deze karaktertrekken samengenomen in een typologie die is opgebouwd vanuit een victal indices warmee de cognitieve stijl van een persoon kan worden omschreven. In bijlage 9 : 'Myers-Briggs Type Indicator, een leeswijzer' wordt een nadere explicatie van deze indicator gegeven.

Ingegeven door de reeds eerder gememoreerde maatschappelijke ontwikkelingen met betrekking tot Corporate Governance ${ }^{24}$ en de beheersing van de organisatie door het management hebben zich ook de controlemethodologieën van de grote accountantsmaatschappen overeenkomstig ontwikkeld [Den Boer en Van Zutphen, 1999; Schwarz, 1998]. In deze controlemethodologieën staat centraal de beoordeling van de maatregelen die het management heeft genomen om de eigen organisatie te beheersen [Gortemaker, Bindenga, Ten Wolde, Van Kollenburg, Wieleman, Krom, Dassen, Coster en Van Sluis, 1998 ${ }^{25}$. Bij het formuleren van de zevende hypothese werd dan ook in hoofdstuk 3 verondersteld dat door deze veranderingen in de controlemethodologieën en dus in de wijze van werken en denken van de 
accountant een verandering in de persoonskarakteristieken van de accountant waarneembaar zou kunnen zijn.

De zevende hypothese was als volgt gefornuleerd:

H7: De veranderende wijze wan werken en denken wan de acconntant doet een werandering verwachen in de persoonlijkheidskatakteristieken wan de accountants in dit onderzoek ten opzichte van acountants in vergelifktare onderzoeken.

Door alle 199 bij het onderzoek betrokken accountants zijn vragenlijsten ingevuld op grond waarvan de voorkeur voor een cognitievestijltype met behulp van de Myers-Briggs Type Indicator kon worden bepaald. Hierbij is gebruik gemaakt van het zogenaande $\mathrm{G}$ formulier ${ }^{26}$ uit de Myers-Briggs Type Indicator ${ }^{27}$.

In het vervolg van deze paragraaf zal eerst gekeken worden naar de verdeling van de cognitieve stijlcategorieën uit dit onderzoek. Daama zal deze verdeling worden vergeleken met de in paragraaf 2.5 weergegeven verdeling, die is ontleend aan de CAPT database en de op basis van andere onderzoeken bepaalde gemiddelden ${ }^{28}$.

In bijlage 27: 'MBTI-indicatoren van 199 accountants volgens huidig onderzoek' zijn de uitkomsten weergegeven. Ook de procentuele verdeling vanuit verschillende invalshoeken is weergegeven. Een antal voorkeuren komt duidelijk nar voren :

- binnen de attitude-index:

de indicator "extraversion" met $57,29 \%$;

- binnen de warnemingsindex: de indicator 'sensing" met 64,33\%;

- binnen de oordeelsvormingindex: de indicator 'thinking' met $83,94 \%$;

- binnen de voorkeursindex: de indicator "judging" met $63,81 \%$.

Ook blijkt dat het STJ-type de meeste accountants vertegenwoordigt. Dit blijkt het geval bij het ISTJ - en ESTJ-type, samen 40,71\%29 van de 199 accountants vertegenwoordigend. Het ST-type vertegenwoordigt $54,29 \%$ en het TJ-type 55,28\% van alle in het onderzoek betrokken accountants.

In bijlage 28: "MBTI-indicatoren huidig onderzoek versus CAPT en overige onderzoeken' is de verdeling van voorkeur voor een cognitieve stijl zoals blijkt uit het huidige onderzoek, vergeleken met de gegevens ontleend aan de CAPT database en het in paragraaf 2.5 berekend gemiddelde over een vijftal andere onderzoeken.

Hieruit blijken voor de individuele indicatoren en de meest van belang zijnde types de volgende verschillen welke in figuur 5.25 zijn weergegeven.

Zoals in paragraaf 2.5 .2 is aangegeven zijn ter vergelijking de gegevens weergegeven van consultants die gespecialiseerd zijn in management analyses [Briggs-Myers en 


\begin{tabular}{|c|c|c|c|}
\hline Huidige onderzoek & $\begin{array}{l}\text { 1.0.v CAPT } \\
\text { onderzoek } \\
\text { accountants. }\end{array}$ & $\begin{array}{l}\text { T.0. } \\
\text { genniddelde } \\
\text { accountants }\end{array}$ & $\begin{array}{l}\text { to, } \mathrm{VAPT} \\
\text { onderzoek } \\
\text { consultants }\end{array}$ \\
\hline Indicator "extraversion" & $12,25 \%$ & $24,54 \%$ & $10,78 \%$ \\
\hline Indicator 'introversion' & $-12,77 \%$ & $-20.91 \%$ & $-11,56 \%$ \\
\hline Indicator 'sensing' & $13,58 \%$ & $5,46 \%$ & $63,65 \%$ \\
\hline Indicator "intuition" & $-17,73 \%$ & $-8,54 \%$ & $-41,23 \%$ \\
\hline Indicator "wininking" & $11,15 \%$ & $11,91 \%$ & $52,45 \%$ \\
\hline Indicator "feeling" & $-34,42 \%$ & $-35.76 \%$ & $-64,26 \%$ \\
\hline Indicator "judging" & $-5,94 \%$ & $-11,38 \%$ & $-0,44 \%$ \\
\hline Indicator "perceiving" & $12,53 \%$ & $29,25 \%$ & $0.61 \%$ \\
\hline [ST]-type & $-3,35 \%$ & $-14,78 \%$ & $45,72 \%$ \\
\hline ESTJ-type & $37,26 \%$ & $31,94 \%$ & $87,48 \%$ \\
\hline STJ-type & $14,16 \%$ & $4,38 \%$ & $64,75 \%$ \\
\hline STT-type & $17,66 \%$ & $15,51 \%$ & $93.34 \%$ \\
\hline TJ-type & $1,01 \%$ & $-1 / 1,29 \%$ & $32,98 \%$ \\
\hline
\end{tabular}

Figutr 5.25: Verschillen tussen het huidige onderzoek, de CAPT onderzoeken en bet gemiddelde.

McCaulley, 1990]. Hieruit is een verschil waarneembaar tussen de karakteristieke voorkeuren van accountants en consultants. Consultants blijken een grotere voorkeur te hebben voor de indicators 'intuition' en 'feeling'.

Een totaaloverzicht van de verschillen van de enkelvoudige en samengestelde indicatoren ten opzichte van de accountants betrokken in het CAPT onderzoek is weergegeven in de figuren 5.26 en 5.27 .

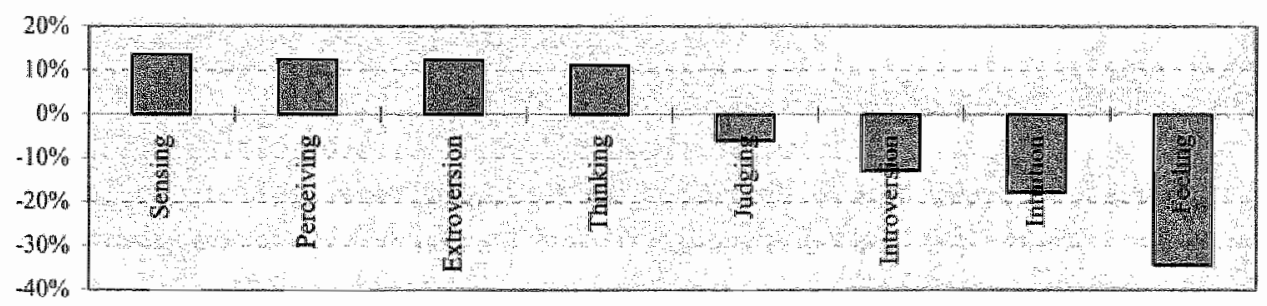

Figuu 5.26: Verschillen per enkelyoudige indicator tussen het thidige en het CAPT onderzoek acconntarts. 


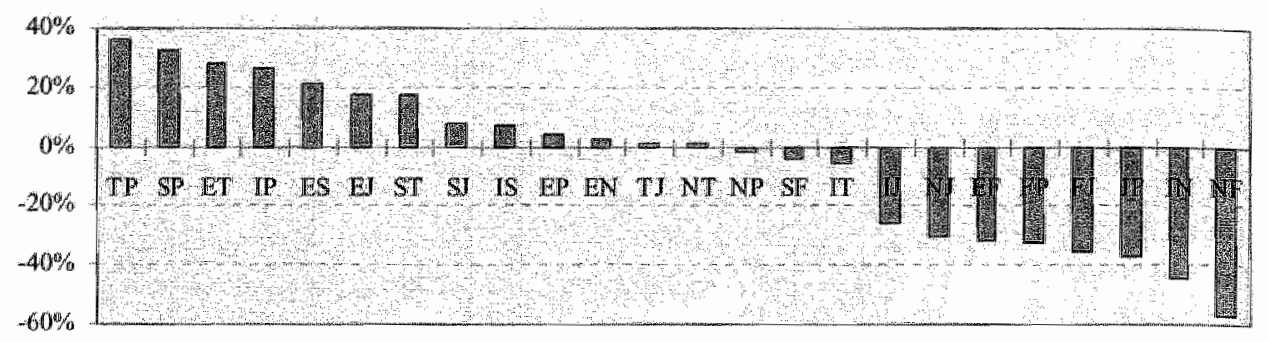

Figutur 5,27: Verségillen per samenstel van indicatoren van het huidige en het CAPT onderzoek accountants.

\section{Conclusie}

Op grond van de gedane observaties kan de conclusie worden getrokken dat de voorkeur van de accountant voor een cognitieve stijlcategorie ongewijzigd uitgaat naar het ESTJ-en het ISTJ-type. Deze voorkeur is nog sterker aanwezig bij de accountants betrokken in dit onderzoek dan bij die welke betrokken zijn bij het langjarige CAPT onderzoek dan well bij het vijftal onderzoeken waaruit het gemiddelde is berekend.

Om redenen van de geschetste maatschappelijke ontwikkelingen gericht op het in control zijn' van het management van zijn eigen organisatie en de daarop volgende ontwikkelingen in de controlemethodologieën en in het werken en denken van de accountant was een verandering te verwachten van de voorkeur van de accountant naar cognitieve stijltypen. Deze verwachting werd evenwel niet bevestigd. Deze bevinding sluit volledig aan bij de conclusie van Wheeler [2001]. Hij stelt vast dat de veranderingen in het accountantsberoep in de latste twee decennia geen gevolgen hebben gehad voor de procentuele verdeling van de accountants naar cognitieve stijlcategorieën. Op grond hiervan moet de zevende hypothese worden verworpen.

\subsection{Samenvatting}

In de vorige paragrafen zijn de observaties, bevindingen en conclusies weergegeven van de onderzoeken die hebben plaatsgevonden. De analyses zijn gegroepeerd naar de drie onderzoeksvragen:

1. de 'consensws' tussen de oordelen van de accountants; als een proxy voor professional judgment;

2. de "voorkeur" van de accountant; als een proxy voor het soort beheersingsmaatregel dat de grootste bijdrage levert aan het prototypisch mentaal model gericht op de beoordeling van administratief-organisatorische processen;

3. veranderingen van het psychologische profiel van de accountant. 
Deze onderzoeken waren erop gericht om conclusies te trekken ten aanzien van de in hoofdstuk 3 gevormde zeven hypotheses. Onderstaand zijn de bevindingen en conclusies kort samengevat. In hoofdstuk 6 worden vervolgens de conclusies ten aanzien van de hypotheses gerelateerd aan het in hoofdstuk 2 beschreven model van Libby [1995]. Daarna worden de onderzoeksvragen uit hoofdstuk 1 beantwoord.

De eerste zes hypotheses hebben betrekking op de evaluatiecriteria consensus en voorkeur. Deze twee evaluatiecriteria zijn ontleend aan het framework van Solomon en Shields [1995] en het framework van Ashton [1983]. Dat veel aandacht gegeven wordt aan het evaluatiecriterium consensus sluit aan bij de bevindingen van Solomon en Shields [1995]. Zij beschouwen dit als passend daar het, door de verwijzing naar gelijkluidende oordelen van andere professionals, als een belangrijke manier wordt gezien om een oordeel te rechtvaardigen. De zevende hypothese is gericht op het optreden van veranderingen in de persoonlijkheidskarakteristieken van de accountant als gevolg van maatschappelijke ontwikkelingen en wijzigingen in controlemethodologieën.

Op grond van de observaties kunnen slechts twee van de zeven hypotheses worden gehandhaafd. Dit betroffen de hypotheses aangaande:

- het niet hebben van een invloed op de consensus tussen de oordelen van de accountants van het soort beheersingsmaatregel maar het aantal verschillende soorten beheersingsmaatregelen dat in een te beoordelen administratief-organisatorisch proces is opgenomen $(\mathrm{H} 3 \mathrm{a})$;

- het niet hebben van een voorkeur voor een bepaald soort beheersingsmaatregel bij accountants (H4).

Geen observaties werden gedaan waardoor de overige hypotheses gehandhafd konden worden. Deze hypotheses hebben betrekking op:

- het bestaan van consensus tussen de oordelen aangaande de toereikendheid van administratief-organisatorische processen $(\mathrm{H} 1)$;

- het hebben van een positieve invloed op de consensus tussen de oordelen van de accountants naarmate het aantal jaren werkervaring in het vakgebied accountancy toeneemt $(\mathrm{H} 2)$;

- het hebben van meer consensus in hun oordelen bij accountants die een gelijk ervaringsniveau hebben met betrekking tot een gelijke mix van soorten interne beheersingsmaatregelen $(\mathrm{H} 3 \mathrm{~b})$;

- het hebben van meer consensus indien accountants behoren tot de twee MBTI waarnemings-en oordeelswormingindex combinaties NT en ST dan behoren tot de warmemings = en oordeelsvormingindex combinaties NF en SF (H5a); 
- het hebben van meer consensus indien accountants behoren tot de ambiguiteitswaarde-groepen waar het merendeel van de accountants in vertegenwoordigd zijn dan behoren tot de andere ambiguiteitswaarde-groepen ( $\mathrm{H} 5 \mathrm{~b})$;

- het hebben van een positieve invloed op de consensus in de oordelen van de accountants naarmate beheersingsmaatregelen voorkomen waaraan de accountants de voorkeur geven ( $\mathrm{H} 6$ );

- het bestaan van een verandering in de persoonlijkheidskarakteristieken van de accountant in het huidige onderzoek vergeleken met accountants in vergelijkbare onderzoeken op grond van maatschappelijke ontwikkelingen ( $\mathrm{H} 7)$.

Ofschoon niet rechtstreeks gekoppeld aan het begrip consensus is nagegaan in hoeverre de afname van het aantal soorten beheersingsmatregelen opgenomen in de beoordeelde casusstellingen van invloed was op de gegeven beoordelingen. Hiervoor is de totale verzameling met onderzoeksgegevens in ogenschouw genomen. Op basis van een aantal verschillende dwarsdoorsneden kan de conclusie worden getrokken dat een correlatie bestaat tussen de door de accountants gegeven waarderingen gegroepeerd naar de verschillende 'subselecties van de onderzoekspopulatie' en het aantal beheersingsmaatregelen begrepen in een casusstelling. De conclusie kan getrokken worden dat in de waarderingen van de accountants gegroepeerd naar de verschillende 'subselectie van de onderzoekspopulatie' rekening gehouden wordt met het aantal soorten beheersingsmaatregelen dat in een casusstelling is opgenomen. 


\section{Noten}

1 Variantieanalyse is een techniek om groepsgeniddelden tegellijkertijd met elkaar te vergelijken. Voor het doun van witspraken wordt een zogenaande nullypothese gefonnuleerd. De nulhypothese is de verwachting die uitgesproken wordt als er niets aun de hand is en derhalve de groepsgemiddelden niet significant van elkaar afwijken. Bij significante verschillen wordt de nulhypothese vernorpen. [Slotboom, 1996].

2 Dir betreffen de casusstelling OR 007, OR 009, OR 013, OR, 014, OR,027 en OR 028 zoals weergegeven in bijlage 13: "Overzicht gegewen waardeoordelen en consensuswaarden".

3 De vier casusstellingen die een andere warderingsmogelijkheid hebben net de hoogste consensuswalade zijn OR021 zonder $P, O, E\}$ met een hoogste consensuswaarde van $44,0 \%$ voor de waarderingsmogeligkheid 'Onvoldoende', OR 026 \{zonder $F, O, E\}$ met een hoogste consensuswaarde van $31.2 \%$ woor de wararderingsmogelijkheid 'Voldoende', OR030 \{zonder P,F,O,E\} met een hoogste consensus waarde van 36,9\% voor de waarderingsmogellijkheid 'Onvoldoende' en ORO32 \{P, F, O,I,E\} met een hoogste consensuswarde van $61,5 \%$ voor de warderingsmogelijkhejd "Onvoldoende".

4 Casusstelling OR001 met hoogste consensuswarde voor de waarderingsmogelijkheid 'Zeer Goed" met 59, $1 \%$, OR 024 met hoogste consensuswaarde voor de warderingsmogelijkheid 'Goed' $58,3 \%$ en OR.032 met hoogste consensuswarde woor de warderingsmogelijkhed 'Onvoldoende' met $61,5 \%$; derlalve een $\mathrm{Cl}(\mathrm{c}, 50 \%$ wa 3 casusstellingen / 32 *1.00\% zijnde $9,38 \%$.

5 Casusstelling ORQ001 met 13 beoordelingen, OR.024 met 7 beoordelingen en OR0.32 met 8 beoordelingen voor re hoogste consensuswararde; derhalve een $\mathrm{Cl}(b, 50 \%)$ van 28 beoordelingen $/ 527 \star 100 \%$ zijnde $5,31 \%$.

6 Door het grote antal verschillende beheersingsmatregelen die een organisatie rer beschikking stat on an te wernden ten einde een proces adequat te beheersen is het niet mogelijk te kunnen spreken van een urieke set van maatregelen samen vormend een normatief model [Meservy, Bailey en Johnson, 1986].

7 Aantal wamentingen $\leq 1 \%$ van het totad.

8 Dezelfde verschillen zijn geconstateerd bij de Kruskal-Wallis toets en de Levene"s test.

9 Dezelfde verschillen zijn geconstateerd bij de Kruskal-Wallis toets en de Levene's test.

10 Zis hiervoor ook bijlage 1: 'Data model'

11 De voorkeurswaarde 1 wordt verkregen indien de beheersingsmatregel door alle accountants op de $5^{2}$ voorkeursplaats is gezet. De voorkeurswaarde 5 wordt werkregen indien de beheersingsmaatregel door alle accountants op de $1^{\text {ste }}$ voorkeursplats is gezet.

12 Waarnemingsindex:

- Sensing (S) bij verzamelen van relevante feiten en realistisclie wijze benaderen ervan;

- Intuition (N) bij ontdekken van nieuwe mogelijkheden en acties;

Oordeelvormingsindex:

- Thüking (T) bij analyseren van alle consequenties van iedere actie;

- Feelling (F) bij vaststellen van warde, verdiensten c.q. vetliezen, van oplossingen.

13 Dezelfde verschillen zijn geconstateerd bij de Kruskal-Willis toets en de Levene's test.

14 Modus en mediaan liggen op +2 , standarddeviatie 5,843 .

15 De verdeling van de ontvangen ambiguïteitwarde is opgenomen in lijlage 20: "Verdeling wardeoordeden per Ambiguiteitwate en beoordelingswarden".

16 Dezelfde verschillen zijn geconstateerd bij de Krukkal-Wallis toets en de Levene's test.

17 Zie hiervoor bijlage 1: 'Data model'.

18 Zie hiervoor bijlage 18: "Verdeling waardeoordelen per voorkeur en beoordelingswaarden'.

19 In bijlage 22: 'Verdeling waardeoordelen condorm wookeur en beoordelingswaarden' zijn de beoordelingswarden opgenomen. Ook is hierbij het verloop grafisch weergegeven. Hierbij zijn de door de accountants gegeven beoordelingen gesorteerd mar het in die casusstelling voorkomen van de beheersingsnaatregel die door de beoordelende accountant op de eerste dan wel de tweede plaats is gezer.

20 bijlage 23: 'Verdeling waardeoordelen zonder voorkeur en becordelings waarden' zijn de beoondelingswararden opgenomen. Ook is hierbij her verloop grafisch weergegeven. Hierbij zijn de door de accountants gegeven beoordelingen gesorteerd naar het niet in die casusstelling voorkomen van de behersingsmaatregel die door de beoordelende accountant op de eerste dan wel de tweede plataty is gezet.

21 Zie bijlage 21: "Verdieling watardeoordelen mate van weerspiegeling en beoordelingswaarden".

22 De interkwartielafstand geeft weer de spreiding wan de middelste $50 \%$ van alle gedane wamemingen.

23 Zie voor een madere beschrijving van de MBTI types bijlage 9: 'Myers-Briggs Type fadicator, een leeswigzer'. 
24 In dit kader zajn te noemen het Amerikaanse rapport COSO, het Engelse rapport Cadbury, het Canadese rapport $\mathrm{COCO}$ en het Nederlandse rapport Tabaksblat.

25 In een artikellenreeks is door de voorzitters van de grote accountantsmatschappen en visie gegeven op de rol van de accountant, nu en in de toekonnst.

26 Het $G$ formulier is voor her eesst gepubliceerd in 1977 . Whe eler [2001] geeft over dit formulier de volgende

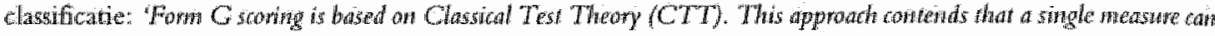

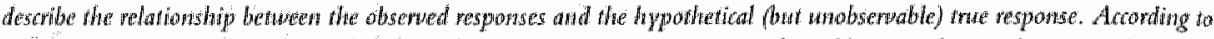

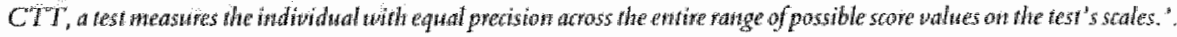

27 De volledige vragenlijst is opgenomen onder bijlage 4: 'Myers-Briggs Type Indicator, de vragenlijst'.

28 Zie hiervoor ook bijlage 24: "MBTl indicatoren van 143 accountants volgens CAPT", bijlage 25: "MBTI indicatoten wan 143 accountants en 89 consultants volgens CAPT' en bijlage 26: 'MBTI uikkomasten wan 181 accourtants volgen diwerse tonderzoken'

29 ISTJ met $19,60 \%$ en ESTJ met $21,11 \%$ 


\section{Beantwoording onderzoeksvragen}

In hoofdstuk 1 is een drietal onderzoekswragen gesteld. Nadat in hoofdstuk 2 het model van Libby [1995] is uiteengezet, is met behulp van dit model in hoofdstuk 3 een zevental hypotheses geformuleerd. Vervolgens is in hoofdstuk 4 het onderzoek uiteengezet en zijn in hoofdstuk 5 de resultaten van de deelonderzoeken en de antwoorden op de hypotheses weergegeven.

In dit hoofdstuk worden de antwoorden gegeven op de gestelde drie onderzoeksvragen. Tevens wordt stilgestaan bij de consequenties die deze antwoorden kunnen hebben voor het accountantsberoep. Daarnaast wordt aangegeven welke vervolgonderzoeken uitgevoerd zouden kunnen worden. Allereerst worden de antwoorden die verkregen zijn op de hypotheses gerelateerd aan het model van Libby [1995].

\subsection{Hypotheses geplaatst in het model van Libby}

In hoofdstuk 2 is het model van Libby [1995] uiteengezet en is ingegaan op de daarin opgenomen vier variabelen. ${ }^{1}$ In figuur 6.1 . zijn de zeven hypotheses, zoals ontwikkeld in hoofdstuk 3 , per onderzoeksvraag weergegeven. Tevens zijn aangegeven de variabele waarop zij betrekking hebben alsmede de bevinding op basis van de uitkomsten van de deelonderzoeken, zoals weergegeven in hoofdstuk 5 . Van het negental hypotheses (inclusief de deelhypotheses), kon één deelhypothese (H3a) en één hypothese $(\mathrm{H} 4)$ worden gehandhaafd. De overige (deel-) hypotheses moesten worden verworpen. Hierdoor kon niet worden vastgesteld dat 'consensus' bestaat met betrekking tot de oordelen van accountants aangaande de toereikendheid van de administratief-organisatorische processen $(\mathrm{H} 1)$. Ook kon niet worden vastgesteld dat het aantal jaren werkervaring in het vakgebied accountancy of het beschikken over meer ervaring, in een specifieke casussituatie een positieve invloed heeft op de 'consensus' tussen de oordelen van de accountants ( $\mathrm{H} 2$ en $\mathrm{H} 3 \mathrm{~b}$ ). Ook een hogere vertegenwoordiging van accountants in een bepaalde cognitieve stijlgroep of groep met tolerantie voor ambiguïteit had geen invloed op de 'consensus' tussen de oorde- 


\section{Mpothese}

V1: consensus tussen de oordelen van de accoumtants

H1 Tussen de oordelen vart accountants angande de Output variabele: toereikendheid van administratief-orgarisatorische "Kwaliteit accountantsoordeel" processen bestatit consenstu.

H2 Een toename wan het aantal jarer wenkerwang in het Inpent variabele: "Ervaring'; vakgebied acconnancy heft een positieve invloed op de Output variabele: consensus tussen de oordelen vari de accountants.

'Kwaliteit accountantsoordeel'

H3a Viet het soort beheremgonatregel mar het antal "Internedate"-output variabele. Ja verschillende soorten beheersingmategelen dar in een "Kennis";

te beordeten administratieforganisatorisch proces is Output wariabele: opgenomen heef inwloed op de consensus tussen de 'Kwalite accountantsoordeel' oordelen van de accountants.

H3b Een toename van het antal malen dat een. gelike mix 'Intermediate'-output variabele: Nex wan sooten interne behersings naatregelen voorkome 'Kernis'; in de praktijk wan de accounant heeft een positieve Ontput wariabele: invloed op de consensus nussen de oordelen van de 'KWaliteit accountantsoordeel' accountanes.

H4 Accountants hebben geen voorkeur voor een bepald "Intermediate"-outpur variabele: Ja soort behowsingsmatregel.

\section{"Kennis"}

Imput variabele: "Aanlleg";

Output variabele:

"Kwaliteit accountantsoordeel" mirng-en oordeelsvormingindex combinaties NT on S zullhen meer conlsersus vertoren dan de accountants behorende tor de warnemings- en oordeelswormingindex combinaties NF en SF.

H5b Accountants behorende tot de ambiguiteitswarde- Input variabele: "Aanleg"; groepen wat het merended van de accountants in Ouput variabele: vertegenwoordigd zijn zullen meer consensus verton en "Kwaliteit accountantsoordeel" dan de accountants veregenwoordigd in de andere ambiguiteitswarde-groepen.

\section{V2: "voorkewe" wan de accountant}

H6 Accountanis zullen in hun oordelen meer consensus vertonen namate beheersingsinatregelen vootkomen waanan zij do "vootkeur" geven.

\section{V3: psychologische profiel van de accountant}

H7 De veranderende wijze van werken en denken van de Inpat warabele: 'Aanleg' Nee

"Intermediate'-outpur variabelle: Nee "Konnis":

Output variabele:

"Kowaliteit accountantsondeel" accoumtant doet een verandering verwachten in de persoonlijkheidskarakteristieken van de accotntants in dit onderzoek ten opzichte van accountants in vergelijkbure onderzoeken.

Figur 6. 1: Hypotheses, model vin Libby en de oordelen 
len van de accountants ( $\mathrm{H} 5 \mathrm{a}$ en $\mathrm{H} 5 \mathrm{~b})$. Van het voorkomen in een casusstelling van een beheersingsmaatregel die als belangrijk is getypeerd, kon geen positieve invloed op de 'consensus' tussen de oordelen van de accountants worden vastgesteld ( $\mathrm{H} 6$ ). Uit dit onderzoek is voorts gebleken dat de persoonlijkheidskarakteristieken van de accountant ten opzichte van andere vergelijkbare onderzoeken niet sterk is veranderd (H7).

In alle uitgevoerde deelonderzoeken zijn wel significante correlaties vastgesteld tussen de door accountants gegeven oordelen en het aantal in de beoordeelde casusstellingen opgenomen soorten beheersingsmaatregelen.

Niet in het onderzoek zijn betrokken de relaties tussen de input variabelen 'Ervaring' en 'Aanleg' en de 'intermediate'-output variabele 'Kennis'. Wel zijn rechtstreekse relaties gelegd tussen 'Ervaring' en 'Aanleg' en 'Kwaliteit accountantsoordeel'. Op basis van de uitspraak van Libby [1995] en Libby en Luft [1993], dat niet alle variabelen en hun onderlinge relaties object van onderzoek behoeven te zijn om toch een volledig inzicht in de kwaliteit van het accountantsoordeel te verkrijgen, behoeft dit geen verstorende factor in het onderzoek te zijn.

Naar aanleiding van Libby en Tan [1994] behoeft de variabele 'Aanleg' niet alleen vanuit het algemeen probleemoplossend vermogen bestudeerd te worden maar kan dit ook plaatsvinden vanuit het besluitvormingsproces. De bestudering van de variabele 'Aanleg' heeft in het onderhavige onderzoek plaatsgevonden vanuit onderzoeksgegevens die ontleend zijn aan de psychologie en die gericht zijn op besluitvaardigheid. Het betreffen onderzoeksgegevens gericht op de cognitieve stijl en de mate van tolerantie voor ambiguiteit. De conclusies getrokken ten aanzien van de hypotheses die op basis hiervan werden geformuleerd konden het bestaan van relaties tussen de input variabele 'Aanleg' en output variabele 'Kwaliteit accountantsoordeel' niet vaststellen.

Indien de hypotheses in het model worden opgenomen ontstat het beeld zoals weergegeven in figuur 6.2. De onderzochte relaties zijn daarbij met een dubbele pijl aangegeven. Tevens is aangegeven of de bevindingen van de onderzoeken de relaties bevestigen.

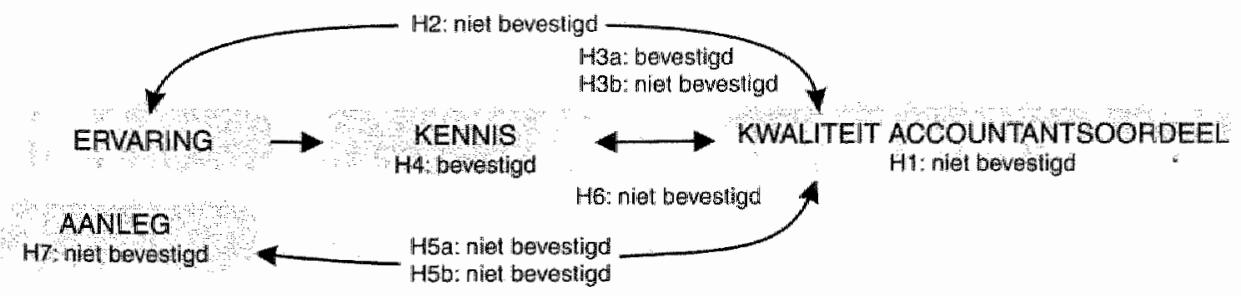

Figutr 6.2: Model van Libby, hypotheses en relaties 


\subsection{Consensus tussen de oordelen van accountants}

In deze paragraaf wordt eerst kort stilgestaan bij de eerste onderzoeksvraag en de wijze waarop het onderzoek is uitgevoerd. Vervolgens worden de conclusies per onderzoekshypothese weergegeven. Daama wordt de eerste onderzoeksvraag beantwoord. Aansluitend wordt deze paragraaf afgesloten met een korte beschouwing aangaande mogelijk toekomstig onderzoek.

\subsubsection{Consensus: inleiding}

In hoofdstuk 1 is uiteengezet dat de accountantsprofessie aan de beoordeling van de administratieve organisatie en de daarin begrepen maatregelen van interne beheersing een centrale plaats toekent bij de controle van de jaarrekening. Daarnaast is het belang angegeven, dat gehecht wordt aan het vormen van een oordeel over de kwaliteit van administratieve-organisatorische processen tegen de achtergrond van vigerende en zich ontwikkelende regelgeving op het gebied van behoorlijk bestuur c.q. corporate governance.

Onder verwijzing naar de plaats van het kernvak Administratieve Organisatie in het curriculum van de accountantsopleiding en het centraal landelijk examen ervan, welke tot en met het collegejaar 2002-2003 theeft gegolden, is geconcludeerd dat de theoretische basis voor alle bij dit onderzoek betrokken accountants, als aan elkaar gelijk is te beschouwen. De praktische invulling van de theoretische basis wordt door meer ervaren accountants verzorgd. Dit gebeurt door het geven van trainingen in het toepassen van controlemethodologieën, het ondersteunen bij de uitvoering van de werkzaamheden ('training on the job'), het begeleiden van de praktijkstages en het verzorgen van presentaties in het kader van de permanente educatie. Regelgeving, standaarden alsmede interne en externe kwaliteitsreviews moeten waarborgen dat de betekenis van de administratief-organisatorische processen inclusief de maatregelen van interne beheersing voor iedere accountant gelijk gestemd is.

Door de grote mate van gelijkvormigheid in opleiding mogen gelijkluidende oordelen verwacht worden bij de beoordeling van vergelijkbare administratief-organisatorische processen. De eerste onderzoeksvraag luidt dan ook als volgt:

V1: Komen acountants bij de beoordeling uangelike adwinistratief-organisatorische processen tot gelijkluidende oordelen?

Deze onderzoeksvraag heeft betrekking op het evaluatiecriterium 'consensus'. Overeenkomstig het framework van Solomon en Shields [1995 $]^{2}$ en het framework van Ashton [1983 $]^{3}$ wordt 'Consensus' gezien als een proxy voor professional 
judgment. Deze proxy vervangt het ontbreken van de normatieve criteria voor de evaluatie van het oordeel van de accountant [Bonner, 1990; Johnson, Jamal en Berryman, 1989; Ashton, 1974a, 1974b].

Uit de theoretische beschouwing in hoofdstuk 2 blijkt dat professional judgment geen eenvoudig begrip is. De accountant ontwikkelt door het evalueren van processen zogenaamde prototypische mentale modellen, welke hij hanteert als normstelling bij volgende evalluaties. Meservy, Bailey en Johnson [1986] verwijzen naar het grote antal verschillende beheersingsmaatregelen dat een organisatie ter beschikking staat ten einde een administratief-organisatorisch proces adequaat te beheersen. Op grond daarvan stellen zij dat het niet mogelijk is te spreken van een unieke set van maatregelen die samen een normatief administratief-organisatorisch model vormen. Zij benadrukken dat de consensus van de beoordelingen door accountants als uitgangspunt genomen moet worden en als proxy gezien kan worden voor het professional judgment [Mouthaan, 2001, 2000; Meservy, Bailey en Johnson, 1986]. Aangezien van accountants verwacht wordt dat zij in vergelijkbare situaties gelijkluidende oordelen geven mag een sterke overeenkomst, het professional judgment, tussen deze prototypische mentale modellen verwacht worden.

Op basis van uitspraken van Mouthaan [2001, 2000], Libby [1995], Meservy, Bailey en Johnson [1986] en Gibbins \1984] kan bij een positieve beantwoording van deze eerste onderzoeksvraag gesproken worden van het bestaan van 'professional judgment'. Bij het bestaan van professional judgment wordt het mogelijk de kwaliteit van het oordeel van een individuele accountant te meten. Hiervoor wordt dan het oordeel van die individuele accountant afgezet tegen het objectieve oordeel van de gehele professie dat dan gehanteerd wordt als normstelling. Indien het bestaan van professional judgment niet kan worden vastgesteld, dan is sprake van een "judgment van een professional'. Dit judgment van een professional is door het gemis aan een objectieve normstelling subjectief van aard.

\subsubsection{Consensus: conclusies hypotheses}

Om de eerste onderzoeksvraag te kunnen beantwoorden is gekeken naar de resultaten van de verschillende deelonderzoeken en het al dan niet verwerpen van de geformuleerde hypotheses zoals weergegeven in hoofdstuk 5 , te weten naar de:

- consensus in de door de accountants gegeven oordelen (\$5.2.1.);

- invloed van het aantal jaren ervaring op consensus, met als variabele het aantal jaren werkervaring $(\$ 5.2 .2$.$) ;$

- invloed van de mix van beheersingsmaatregelen op consensus, met als variabele de soort beheersingsmaatregel $(\$ 5.2 .3 .1$ ); 
- invloed van de bekendheid met de casusstelling op consensus, met als variabele het voorkompercentage $(\$ 5.2 .3 .2$ );

- invloed van het belang van een beheersingsmaatregel, met als variabele de soort beheersingsmaatregel op de eerste en tweede voorkeursplaats $(\$ 5.2 .4$.);

- invloed van de verdeling van de cognitieve stijl op consensus, met als variabele de combinatie van waamemingsindex en oordeelsvormingindex $(\$ 5.2 .5 .1$.);

- invloed van de mate van tolerantie voor ambiguitteit op consensus, met als variabele de ambiguiteitsgroep $(\$ 5.2 .5 .2)$,

Zoals in paragraf 5.2.6. is weergegeven kan, gelet op de lage consensusindices, niet geconcludeerd worden dat aantoonbaar is gemakt dat sprake is van consensus tussen de oordelen van accountants aangaande de toereikendheid van administratief-organisatorische processen. Hierdoor kan geen invulling gegeven worden an de stelling van Mouthaan [2001, 2000] en Meservy, Bailey en Johnson [1986] dat de consensus van de beoordelingen van accountants het gemis van een normatief model van beheersingsmaatregelen kan opvangen.

Niet is vastgesteld dat één van de hiervoor genoemde in een deelonderzoek betrokken variabelen van invloed is op de variantie in de beoordelingswaarde van de casusstellingen.

\subsubsection{Consensus: beantwoording eerste onderzoeksvraag}

Op grond van vorenstaande conclusies kan een antwoord gegeven worden op de eerste onderzoeksvraag, die luidt:

V1: Komen accountants bij de beourdeling van gelijke administratief-organisatorische processen tot gelijkluidende oordelen?

Gebaseerd op de resultaten van de deelonderzoeken, en met name de grote spreiding in de gegeven oordelen, kan de eerste onderzoeksvraag niet positief worden beantwoord.

Bij de gegeven antwoorden bleek geen sprake te zijn van aantoonbare consensus. Toch had een dergelijke consensus verwacht mogen worden als uitgegaan wordt van de onderzoeken van Gaumnitz, Nunamaker, Surdick en Thomas [1982] en Hamilton en Wright [1982]. Een dergelijke verwachting wordt ook niet tegengesproken door de uitkomsten van de onderzoeken van Libby en Libby [1989] en Mayper, Doucet en Warren [1989]. 
Hierdoor kon geen eenduidige normstelling worden ontwikkeld als toetsingsnorm zoals voorgesteld door Mouthaan [2001, 2000] en Meservy, Bailey en Johnson [1986].

Derhalve is met dit onderzoek het bestaan van het 'Professional Judgment', als zijnde een duidelijke normstelling noodzakelijk volgens Libby [1995] om na te gaan hoe goed een opgedragen taak is uitgevoerd, niet vastgesteld. Volgens dit onderzoek kan alleen maar sprake zijn van een 'Judgment van een Professional'. Nader onderzoek dient gedaan te worden naar de invloed van de beperkingen die in dit onderzoek aanwezig zijn, zoals:

- het hanteren van een minimale consensuswaarde-grens van $50 \%$ bij een zevenpuntsschaal;

- het als subsidiair beschouwen van soorten beheersingsmaatregelen;

- het niet in de analyse betrekken persoonlijke omstandigheden van de beoordelende accountants welke eveneens een bijdrage leveren aan het opbouwen van het prototypisch mentaal model dat door de accountant als toetsingskader wordt gehanteerd;

- andere niet in het onderzoek betrokken variabelen welke van invloed zouden kunnen zijn op de uitkomsten van dit onderzoek.

Ofschoon de accountant bij de controle van de jaarrekening gebruik maakt van zijn bevindingen inzake de effectiviteit van de administratieve organisatie is dit niet het enigste controlemiddel dat de accountant ten dienste stat. De uitkomst van dit onderzoek mag niet geïnterpreteerd worden als dat jaarrekeningen hierdoor ten onrechte voorzien zijn van goedkeurende accountantsverklaringen.

\subsubsection{Consensus: toekomstig onderzoek}

In dit onderzoek is de achtergrond van de participerende accountants met betrekking tot de accountantsorganisatie waartoe zij behoren buiten beschouwing gelaten. Derhalve kan geen uitspraak worden gedaan omtrent de mate van invloed hiervan op de twee onderdelen van de procedural knowledge, te weten:

- de vorming van de 'Semantic procedural knowledge'; en

- de vorming van de 'Episodic procedural knowledge'.

Daarnaast zijn vorenstaande conclusies getrokken op basis van het kennisdomein Bedrijtseconomie; Administratieve Organisatie. Dit is slechts éen kennisdomein van de accountant. Het bezien van het professional judgment op individuele basis wil derhalve in het geheel niet zeggen dat getwijfeld moet worden aan de verklaringen die bij de jaarrekeningen worden gegeven. Immers een accountant gebruikt de uitkomsten van de beoordeling van een bedrijfsproces als één van de constituerende factoren voor het controleprogramma dat daarna verder uitgewerkt dient te worden. 
Toekomstig onderzoek dient dan ook inzicht te geven in:

- de invloed van de accountantsorganisaties op het procedural knowledge en op de vorming van professional judgment;

- de invloed die een oordeel over een bedrijfsproces heeft op het verdere verloop van de accountantscontrole. Hierbij dient tevens nagegaan te worden op welke wijze de verschillende constituerende factoren met elkaar samenhangen. Als andere constituerende factoren zijn onder meer te noemen de omgeving waarin de onderneming werkzaam is, het marktsegment, de marktpenetratie, de lifecycle van het gevoerde product danwel dienst etc;

- de wijze warop het theoretische gedeelte van de accountantstudie wordt omgezet in een praktische benadering van het probleemgebied. Een zelfde opleiding die leidt tot een groot aantal verschillende antwoorden op dezelfde vragen impliceert dat de theoretische basis verstoord wordt door factoren die niet in het curriculum zijn opgenomen. Hierbij kan gedacht worden aan een conservatieve en wellicht controversiële beïnvloeding van de junior medewerkers door oudere medewerkers binnen de werkomgeving;

- hoeverre partners binnen een accountantsmaatschap gezien worden als 'rolemodel' voor de jongere medewerkers en de invloed hiervan op hun redeneren en de wijze waarop zij beslissingen nemen.

\section{3. 'Voorkeur' van de accountant?}

In deze paragraaf wordt eerst kort stilgestaan bij de tweede onderzoeksvraag en de wijze waarop het onderzoek is uitgevoerd. Vervolgens worden de conclusies van de onderzoekshypothese weergegeven. Daama wordt de tweede onderzoeksvraag beantwoord. Deze paragraaf wordt afgesloten met een korte beschouwing aangaande mogelijk toekomstig onderzoek.

\subsection{1. 'Voorkeur': inleiding}

In hoofdstuk 1 is aangegeven dat de verschijningsvorm van het systeem van administratieve organisatie en maatregelen van interne beheersing situationeel bepaald is. $B i j$ de vormgeving van het systeem van administratieve organisatie door het management wordt een keuze gemaakt uit een groot aantal administratief-organisatorische procedures en maatregelen van interne beheersing. Richtinggevend voor de keuze die het management van de organisatie maakt zijn niet alleen hun persoonlijke voorkeuren maar ook de karakteristiek van de onderneming zelve. 
Door systematisch gebruik te maken van gegevens en informatie, ontwikkelt de individuele accountant een relatief begrip van de mate van belangrijkheid van die gegevens en informatie in het oordeelsvormingproces. Dit relatieve begrip wordt weergegeven in een ordening van subjectieve gewichten waarmee een prototypisch mentaal model wordt opgebouwd. Indien dit prototypisch mentaal model van een accountant overeenkomt met objectief bepaalde indicatoren, kan gesteld worden dat die accountant beschikt over een goede 'voorkeur' [Wright, 1977]. Hierbij wordt geappelleerd aan enerzijds de 'Episodic procedural knowledge' en anderzijds aan de toepassing van deze kennis in een specifieke omgeving. Door het ontbreken van een unieke set van maatregelen die een normatief administratief-organisatorisch model vormen [Mouthaan, 2001, 2000; Meservy, Bailey en Johnson, 1986], zal de ontwikkeling van het 'Episodic procedural knowledge' sterk beinvloed worden door directe persoonlijke ervaringen in opdrachtsituaties. De tweede onderzoeksvraag zoals gesteld in hoofdstuk 1 heeft betrekking op het evaluatiecriterium "voorkeur" volgens het framework van Solomon en Shields [1995] en het framework van Ashton $[1983]^{5}$ en luidt:

V2: Is de voorkeur van de accountants voor een bepaald soort beheersingsmaatregel van invloed op de consensus in de oordelen?

Om op deze vraag antwoord te kunnen geven is uitgegaan van het voorkomen van een door de accountant uitgesproken voorkeur voor een type beheersingsmaatregel. Deze voorkeur werd uitgesproken door de desbetreffende maatregel een eerste danwel de tweede plaats toe te kennen. Uit de beantwoording van de onderzoeksvraag is reeds gebleken dat de voorkeur voor de 'Proces' beheersingsmaatregel het hoogst was en voor de 'Informatie' beheersingsmaatregel het laagst.

\subsection{2. 'Voorkeur': conclusies hypotheses}

Ond de tweede onderzoeksvraag te kunnen beantwoorden is gekeken naar de resultaten van een deelonderzoek en het al dan niet verwerpen van de geformuleerde hypothese zoals weergegeven in hoofdstuk 5 , te weten naar de invloed:

- van het voorkomen van beheersingsmaatregelen die de accountant als meest belangrijk vindt op 'consensus', met als variabele de mate van weerspiegeling (\$5.3.).

Zoals in paragraaf 5.3. is weergegeven, is een positieve verschuiving in de waardering vastgesteld indien sprake was van het aanwezig zijn van een beheersingsmaatregel welke door de beoordelende accountant als meest belangrijk wordt aangemerkt. 
Niet is vastgesteld dat de mate van weerspiegeling van invloed is op de variantie in de beoordelingswarde wan de casusstellingen.

Ofschoon niet rechtstreeks gerelateerd an het uitgangspunt van 'voorkeur' is een tweetal opmerkingen met betrekking tot de waarderingen te maken, te weten:

- met betrekking tot het al dan net voorkomen van Financiele beheersingsmaatregelen is geen verschil in de wardering vastgesteld;

- met het afnemen van het antal soorten beheersingsmatregelen is een negatieve verschuiving in de waardering vastgesteld.

\subsection{3. 'Voorkeur': beantwoording tweede onderzoeksvraag}

Op grond van voronstaande conclusies kan een antwoord gegeven worden op de tweede onderzoeksvraag, die luidt als volgt:

V2: Is de vookeur van de accountants voor een bepaald soort beheersingsmaatregel van invloed op de consensus in de oordelen?

Gebaseerd op de resultaten van het onderzoek kan de tweede onderzoeksvraag niet positief worden beantwoord.

Vastgesteld is dat binnen het kennisdomein de accountant beschikt over 'voorkeur'. Het belang dat de accountant hecht aath een groep beheersingsmatregelen wordt gereflecteerd in het door de accountant gegeven oordeel. Het voorkomen van een beheersingsmaatregel die de voorkeur heeft van de beoordelende accountant, heeft invoed op de gegeven wardeoordelen; het leidt tot een positievere waardering. Niet is vastgesteld dat de mate van weerspiegeling van invloed is op de consensus tussen de oordelen van de accountants angaande de toereikendheid wan administratieforganisatorische processen.

\subsection{4. 'Voorkeur': toekomstig onderzoek}

Vorenstaande negatieve conclusie is getrokken op basis van het kennisdomein Bedrijfseconomie; Administratieve Organisatie. Zoals ook in paragraf 6.2. is aangegeven, is dit slechts één kennisdomein van de accountant. Het hebben van 'vootkeur' is derhalve bij een zeer specifiek kennisdomein vastgesteld. Binnen dit kennisdomein is het slechts vastgesteld voor een ondersteunend bedrijfsproces dat bij iedere client van de accountant aanwezig verondersteld wordt. Hierdoor mocht verondersteld worden dat alle accountants betrokken in het onderzoek kennis hebben van het ondersteunend bedrijfsproces. Het belang van deze vaststelling dient gezien te worden tegen de achtergrond van de opleiding tot accountant. Dit kennisdomein 
wordt gevormd met behulp van één van de kernvakken wan de opleiding: het vak Administratieve Organisatie. Op grond hiervan kan nog geen algemene conclusie getrokken worden over de 'voorkeur' van de accountant op zijn volledige vakgebied.

Toekomstig onderzoek dient dan ook inzichtelijk te maken in hoeverre:

- sprake is van 'voorkeur' bij andere al dan niet ondersteunende bedrijfsprocessen. Hierbij zou nagegaan kunnen worden in hoeverre een correlatie bestaat tussen de mate van 'voorkeur' van de accountant en de frequentie warmee het in de beoordeling betrokken bedrijfsproces voorkomt binnen organisaties;

- sprake is van 'voorkeur' in verschillende andere kennisdomeinen welke als belangrijk voor de accountant worden verondersteld, zoals \{Bedrijfseconomie; Informatie Management\}, \{Bedrijfseconomie; Interne Berichtgeving\} of \{Bedrijfseconomie; Exteme Verslaggeving\};

- een correlatie bestaat tussen de mate van 'voorkeur' van de accountant en de ervam ring van de accountant met het bedrijfsproces dat in de beoordeling is betrokken;

- de verschillende opleidingscomponenten en zijn werkervaring een bijdrage leveren aan het prototypisch mentale model van de accountant.

\subsection{Het psychologische profiel van de accountant.}

In deze paragraaf wordt eerst kort stilgestaan bij de derde onderzoeksvraag en de wijze warop het onderzoek is uitgevoerd. Vervolgens worden de conclusies van de onderzoekshypothese weergegeven. Daarna wordt de derde onderzoeksvraag beantwoord. Deze paragraaf wordt afgesloten met een korte beschouwing aangaande mogelijk toekomstig onderzoek.

\subsubsection{De persoonlijkheidskarakteristieken van de accountant : inleiding}

In hoofdstuk 1 is aangegeven dat in de afgelopen decennia een ontwikkeling heeft plaatsgevonden in de wijze van controleren. Deze ontwikkeling geeft een verschuiving te zien van meer gegevensgericht naar meer systeemgericht. Met deze ontwikkeling volgt de accountant de ontwikkelingen op het gebied van beheersing van de bedrijfsprocessen zoals het management van de ondernemingen deze ontwikkeling ondergaat.

Voorts wordt de accountant steeds vaker gevraagd een oordeel te geven over de kwaliteit van de beheersing door het management van de bedrijfsprocessen in het kader van de zogenaamde corporate governance discussie [Public Oversight Board, 2000; 
Gortemaker, Bindenga, Ten Wolde, Van Kollenburg, Wieleman, Krom, Dassen, Coster en Van SJuis, 1998].

Door deze ontwikkelingen mogen van de accountant andere eigenschappen verwacht worden. De derde onderzoekswraag, zoals gesteld in hoofdstuk 1, heeft, in aansluiting op een door Schloemer en Schloemer [1997] uitgevoerd onderzoek, betrekking op de verwachte veranderingen in de persoonlijkheidskarakteristieken van de accountant en luidt:

V3. Wijk het psychologische profiel wan de acom tats die meegewerkt hebben aan deze studie af van dat van accowntants die hebben megewerkt an andere soortgelife stadies?

Om op deze vraag antwoord te kunnen geven is uitgegaan van de cognitieve stijlcategorisatie volgens de Myers-Briggs Type Indicator met als referentie een arntal in het verleden uitgevoerde studies die eveneens gebruik hebben gemaakt van deze indicator en betrekking hadden op accountants.

\subsubsection{De persoonlijkheidskarakteristieken van de accountant: conclusies hypotheses}

Om de derde onderzoeksvraag te kunnen beantwoorden is gekeken naar de resultaten van een deelonderzoek en het al dan niet verwerpen van de geformuleerde hypothese zoals weergegeven in hoofdstuk 5 , te weten naar de:

- invloed die de beoordeling van de toereikendheid van de beheersing van processen heeft op de persoonlijkheidskarakteristieken van de accountant $(\$ 5.4$.).

Zoals in paragraf 5.4. is weergegeven is vastgesteld dat de voorkeur van de accountant voor een cognitieve stijlcategorie ongewijzigd uitgaat naar het ESTJ en het ISTJ-type. Gebleken is dat deze twee types, binnen de onderzoekspopulaties, sterker vertegenwoordigd waren dan op grond van een langjarig onderzoek uitgevoerd door het CAPT verwacht mag worden. Ook het gemiddelde, berekend uit een vijftal andere onderzoeken, was minder sterk.

De verwachting, dat in de voorkeur van de accountant de indicatoren zouden veranderen werd niet bevestigd, hetgeen ansluit bij de bevindingen van Wheeler [2001].

\subsubsection{De persoonlijkheidskarakteristieken van de accountant: beantwoording derde onderzoekswraag}

Op grond van vorenstaande conclusies kan een antwoord gegeven worden op de derde onderzoeksvraag, die luidt als volgt: 
V3: Wijkt het psychologische profiel van de accountants die meegewerkt hebben aan deze studie af van dat van accountants die hebben meegewerkt aan andere soortyelijke studies?

Gebaseerd op de resultaten van het deelonderzoek kan de derde onderzoeksvraag niet positief worden beantwoord.

Een toename in de frequentie waarmee in de onderzoekspopulatie de accountants voorkomen in een tweetal cognitieve stijlcategorieën tendeert naar een verandering van het type mens. Immers, het impliceert een versterking van de cognitieve stijlen waartoe de accountant behoort. Deze versterking van de traditionele cognitieve stijlcategorie van de accountant werd vastgesteld.

Het niet positief kunnen beantwoorden van de derde onderzoeksvraag geeft aan dat de ontwikkelingen in de controlemethodologieën geen invloed hebben op de ontwikkeling van andere dan de traditionele persoonlijkheidskarakteristieken bij de accountant.

\subsubsection{De persoonlijkheidskarakteristieken van de accountant: toekomstig onderzoek}

Vorenstaande conclusie is getrokken op basis van een populatie van afgestudeerde registeraccountants, werkzaam als openbaar accountant. Teneinde verder inzicht te verkrijgen in de ontwikkelingen van de cognitieve voorkeur en dus de persoonlijkheidskarakteristieken van accountants zou een longitudinaal onderzoek uitgevoerd moeten worden. Als gevolg van de ontwikkeling die een individu doormaakt alsmede de ervaringen die hij opdoet, zullen elementen op grond warvan het type waarin een individu kan worden ingedeeld veranderen.

Toekomstig longitudinaal onderzoek dient dan ook inzicht te geven in:

- de veranderingen in het cognitieve stijltype gedurende:

o de opleiding tot de afronding van het theoretische deel van de opleiding;

o de te volgen praktijkstage;

o de permanente educatie periode;

- de invloed van een veranderende controlemethodologie op het type. Hierdoor kan inzichtelijk worden in hoeverre de doelstellingen van een substantiële wijzjging in een controlebenadering daadwerkelijk kunnen worden gehaald alsmede wanneer sprake is van een substantiële wijziging in de controlebenadering;

- wijzigingselasticiteit, gemeten als de tijdsspanne tussen de implementatie van een substantiële wijziging in de controlebenadering en de daadwerkelijke verandering in de persoonlijkheidskarakteristieken van de accountant. 


\subsection{Consequenties voor de accountantsprofessie}

In hoofdstuk 1 is stilgestaan bij de relevantie van dit onderzoek. Verwezen wordt daarbij naar de transparantie bimnen de financiële wereld waarop vanuit diverse kanten wordt aangedrongen. Aangezien de accountant eveneens een rol vervult in de financiële wereld, zal ook bij de accountant aangedrongen worden op transparantie. Deze transparantie vertaalt zich dan in het inzichtelijk maken van het besluitwormingsproces dat de accountant heeft gevolgd om te komen tot zijn verklaring. Het hebben van internationaal aanvaarde controlestandaarden is een eerste stap in die richting, die direct gevolgd wordt door daarop afgestende controlemethodologieën. Dit alles geeft de accountant ondersteuning bij de uitvoering van zijn werkzaamheden. Aangezien het een persoonlijke beroepsuitoefening betreft zal de individuele accountant zijn eigen besluiten moeten nemen. Gebaseerd op de door hem verkregen audit-evidence zal de accountant tot een oordeel moeten komen. Één van de hoekstenen in het controlegebouw is de beoordeling van de administratieve organisatie en de daarin begrepen matregelen van interne beheersing. Met andere woorden het verkrijgen van het antwoord op de vraag: 'heeft het management zijn bedriffsprocessen in de greep?'. Dat het hier een hoeksteen betreft moge onder meer blijken uit de plats die het betreffende vak inneemt in het huidige curriculum van de accountantsopleiding en de plaats die het toegedicht krijgt in de International Education Standards van de IFAC [IFAC, 2003a].

Om een optimale transparantie met betrekking tot het oordeel over de beheersing van bedrijfsprocessen door het management te kunnen bereiken dient het accountantsberoep het bestaan van haar professional judgment duidelijk aan te tonen. De opleiding tot accountant alsmede de verplichte permanente educatie en de bestaande kwaliteitsreviews maken dat de accountant gezien wordt als een professional die zeer zeker 'judgmental' capaciteiten bezit. Daarvoor kan in de uitkomsten van het onderzoeksgedeelte, uitgevoerd met behulp van de Myers-Briggs Type Indicator, bevestiging gevonden worden.

Zoals in hoofdstuk 2 is aangegeven kan bij professional judgment sprake zijn van 'judgment van de professie' danwel van 'judgment van de professional'. Van Eijkelenburg [2001] stelt dat professional judgment meer is dan het judgment van een individuele professional. Het is de representatie van het geheel van oordelen gegeven door het collectief van individuele professionals behorende tot een bepaalde professie. In de onderhavige studie is professional judgment bezien vanuit deze optiek.

Professional judgment wordt in dat geval getoond indien de individuele professionals in gelijke situaties tot gelijkluidende oordelen komen. Consensus van accountantsoordelen, zijnde het niveau van gelijkluidende oordelen [Solomon en Shields, 
1995; Ashton 1983], wordt gezien als een proxy voor professional judgment, bezien vanuit het gezichtspunt van de accountantsprofessie. Voor een dergelijke consensus is een duidelijke normstelling noodzakelijk. Deze normstelling is met betrekking tot het beoordelen van administratief-organisatorische processen evenwel niet voorhanden. De individuele accountant zal ten behoeve van de beoordeling een prototym pisch mentaal model ontwikkelen dat als normstelling door hem wordt gehanteerd Dit prototypisch mentaal model is een gestructureerde weergave van de door instructie en ervaring opgebouwde kennis. Teneinde tot gelijkluidende oordelen in gelijke situaties te kunnen komen zullen de prototypische mentale modellen van de verschillende accountants en de wijze waarop de verschillende accountants hiermee omgaan in hun onderlinge combinatie, eveneens gelijkluidend moeten zijn. Deze combinatie is richtinggevend voor het professional judgment bezien vanuit de accountantsprofessie. Deze prototypische mentale modellen dienen te worden geëxpliciteerd en verder ontwikkeld te worden tot een nomenkader dat tijdens de opleiding tot registeraccountant kan worden gehanteerd en getoetst.

Met behulp van de verplichte permanente educatie [IFAC, 1998] en het zo ontwikkelde normenkader kan de in de praktijk werkzame accountant worden bijgeschoold waardoor de accountantsprofessie kan aantonen over een grote mate van robuustheid ten aanzien van de beoordeling van administratief-organisatorische processen te beschikken. Wel wordt opgemerkt dat de inhoudelijke vrijblijvendheid van de permanente educatie omgezet moet worden naar een systeem van verplichte permanente educatie waarvan sanctioneren onderdeel uitmakkt. Een aanscherping van de huidige wijze waarop de permanente educatie [IFAC, 1998] wordt ingevuld wordt verplicht vanaf 1 januari 2006. Deze intemationale IFAC opleidingsstandaard gaat uit van gestructureerde educatie met een tweetal meetlatten, een minimum aantal uren per jaar danwel 'output'-meting [IFAC, 2004b]. Deze latste wijze van meten van de permanente educatie kan gedaan worden door een periodieke 'reexaminatie". Het voordeel van deze wijze van meeting is dat het effect van de permanente educatie gemeten kan worden. Indien de accountant afgerekend wordt op de door hem gevolgde permanente educatie en in deze permanente educatic aandacht wordt besteed aan de beoordeling van de administratief-organisatorische processen kan dit tevens een verdere ontwikkeling van het zogenaamde 'professional scepticisme' tot gevolg hebben. Ofschoon periodieke 're-examinatie' niet rechtstreeks het geschetste probleem oplost wordt hiermee wel een bijdrage geleverd aan het inzichtelijk maken van het probleem waardoor door gerichte acties tot oplossingen gekomen kan worden.

Samenvattend kan gesteld worden dat de accountantsprofessie gedwongen door de maatschappelijke ontwikkelingen en de roep om meer transparantie gebaat zal zijn bij het aantoonbaar beschikken over professional judgment. Dit professional 
judgment kan tot uitdrukking worden gebracht in de consensus in de oordelen van accountants in gelijke situaties. Indien dit professional judgment wordt geconcretiseerd in nomarieve modellen wordt het maatschappelijk verkeer in de gelegenheid gesteld oordelen van accountants te valideren, met deze modellen als normstelling. De accountants kumnen onder toepassing van deze normstelling een grotere transparantie in hun besluitvorming brengen waardoor het maatschappelijk verkeer beter inzicht wordt gegeven in de hun moverende redenen op grond waarvan een oordeel is gegeven.

\subsection{Samenvatting}

In clit hoofdstuk is antwoord gegeven op de drie onderzoeksvragen zoals geformuleerd in hoofdstuk 1. Uit figuur 6.3. blijkt dat geen van de onderzoeksvragen positief beantwoord kon worden.

\section{Onderzodksvrang}

Vi Komen accomntarts bij de beoordeling van gelijke administratieforganisatorische processen tot gelijkluidende oordelen?

V2 Is de voorkeur wan de accountants voor cen bepald soort betheersingmatregel van invloed op de consensus in de oordelen?

V3 Wijkt het psychologische profiel wain de accountants die meegewerkt hebben an deze studive af van dat van acountants die hebben meegewerkt an andere soortgeligke studies?

Gericht op Uitspraak
Evaluatiecriterium
"Consensus'
Evaluatiecriterium
"Voorkexr
'Cognitieve
stijlcategorie'

Figuur 6.3: Beantwoording onderzocksvragen

De eerste onderzoeksvraag bleek niet positief te beantwoorden. Door de grote mate van spreiding in de gegeven antwoorden kon niet aantoonbaar worden gemaakt dat sprake is van consensus tussen de oordelen van de accountants. Well werd vastgesteld dat de accountant geen voorkeur heeft voor een soort beheersingsmatregel en dat niet het soort beheersingsmaatregell maar het aantal beheersingsmaatrgelen van invloed is.

De tweede onderzoeksvraag bleek niet positief te beantwoorden. Niet is vastgesteld dat het hebben van een voorkeur van invloed is op de consensus tussen de oordelen van de accountants. Opgemerkt wordt dat wel is gebleken dat het hebben van een voorkeur bij de accountant voor een groep beheersingsmaatregelen van invloed is op de door de accountant gegeven oordelen.

De derde onderzoekswraag bleek niet positief te beantwoorden. Accountants bleken ten opzichte van langjarige andere onderzoeken nog steeds een voorkeur te hebben voor dezelfde cognitieve stijlcategorieën. 
Gelet op de conclusie met betrekking tot de theoretische basis waardoor de accountant tot professional is gevormd, is eerder sprake van het 'judgment van een individuele professional' dan van 'professional judgment' zoals verwoord in hoofdstuk 2 . De beoogde transparantie in de oordeelsvorming van de accountant op het gebied van de beoordeling van de beheersing van bedrijfsprocessen wordt hierdoor niet bevorderd. Daarnaast wordt de mogelijkheid om te komen tot een objectief beoordelingskader gericht op de efficiëntie van de werkzaamheden uitgevoerd door een individuele accountant in het kader van de controle van de jaarrekening niet ontwikkeld en gehanteerd.

\section{Noten}

1 Libby [1995] geef de volgende betekenis an de wariabelen:

- enoring: onderwindingen tijdens de uirvoening van opdrachten die de mogeljkblueid bieden dararan te leren (inputvariabele);

- kennis: informatie vastgelegd in het geheugen (intemediate'-output varabele );

- aunleg; capaciteit om informative verwerkende tatksthingen vit te voeren (inputvariabele);

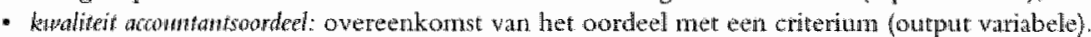

2 Consensus wolgens Solomon en Shields [1995]: het niveaw van gegeven geligkliddendo oordelen.

3 Consensus volgens Ashton [1983]: geljikhidendheid varu cordelen zowel gemeten tussen de accountants van binnen een firma als bimen de totale professie.

4 "Voorkeur" wolgens Solomon en Shields [1995]: de correlatie tussen de modellen van een individu en de mate van relatieve bellangrijkheid van dat model ten opzichte wan andere modellen.

5 "Voorkeur" volgens. Ashton [1983]: de kwaliteitsmatstaf voor het eigen begrip dat de accountant henft ten aanzien wan het eigen besluitvormingsproces. 
192 


\section{Literatuur}

Abdel-Khalik, A.R., Solomon, I., Research Opporturtities in Anditing: The Second Deade, American Accounting Association, 1988

Abdolmohammadi, M., Wright, A., An Examination of the Effects of Experience and Task Complexity on Audit Judgments, The Accounting Review, Vol. 62, No. 1, January, 1987

AICPA, Codjfication of Auditing Standards (indwding AICPA and PCAOB anditing and Attestation Standards), AlCPA, New York, January 2004

Anderson, M.J., A Comparative Analysis of Information Search and Evaluation Behavior of Professional and Non-professional Financial Analysts, Acconating Organizations asd Society, Vol. 13, No. 5, 1988

Ashton, A.H., Experience and Error Frequency Knowledge as Potential Determinants of Audit Expertise, The Accownting Review, Vol. 66, No. 2, April, 1991

Ashton, A.H., Does Consensus Imply Accuracy in Accounting Studies of Decision Making?, The Accownting Review, Vol. 60, 1985

Ashton, R.H., Research in Audit Decision Making: Rationale, Evidence, and Implications, The Canadian Certified General Accountants' Research Foundation, 1983

Ashton, R.H., An Experimental Study of Internal Control Judgments, Joumal of Accounting Researh, Spring, 1974a

Ashton, R.H., Cue Utilization and Expert Judgments: A Comparison of Independent Auditors with Other Judges, Journal of Applied Psychology, Vol. 59, No. 4, 1974b

Ashton, R.H., Ashton, A.H., Perspectives on Judgments and Decision-Making Research in Accounting and Auditing, Judgment and Decision-Making Resewch in Acconting and Anditing, Cambridge University Press, New York, 1995

Ashton, R.H., Brown, P.R., Descriptive Modeling of Auditors Internal Control Judgments: Replication and Extension, Joumal of Acrownting Reyearh, Spring, 1980

Ashton, R.H., Kramer, S.S., Students as Surrogates in Behavioral Research: Some Evidence, Joumal of Accounting Research, Spring, 1980

Bailey C.D., CIAs and CPAs: Do They Agree on Internal Accounting Controls?, Intemal Auditor, February, 1990

Bamber, M.E., Expert Judgment in the Audit Team: A Source Reliability Approach, Joumal of Acosurting Research, 21,1983

Bëdard, ., The Effect of Practice on Content and Structure of Auditors' Knowledge, paper presented at the 17th Annual Congress of the European Accounting Association, Venice, April, 1994

Bedard, J., Unreliable Evidence in Auditing: The Problern, its Impact and Solutions, paper presented at the 14th Annual Congress of the European Accounting Association, Maatricht, The Nethertands, 1991a

Bédard, J., Expertise and its Relation to Audit Decision Quality, Contemporary Acconuting Research, Vol. 8, No. 1, Fall, $1991 \mathrm{~b}$ 
Bédard, J., Expertise in Auditing: Myth or Reality?, Accounitug, Organizations and Society, Vol. 14, Nos. $1 / 2,1989$

Bédard, J.C., Biggs, S.F., Pattern Recognition, Hypothesis Generation, and Auditor Performance in an Analytical Task, The Accounting Review, Vol. 66, No. 3, July, 1991

Bédard, J, Chi, M. T.H., Expertise in Auditing, Awditing: A Joumal of Practice E Theorie, Vol. 12, Supplement, 1993

Bédard, J., Grahan Jr., L.E., Auditors' Knowledge Organization: Observations from Audit Practice and Their Implications, Anditing: A Joumal of Practice and Theory, Vol. 13, No. 1, Spring, 1994

Bedard, J., Graham, L.E., the Effects of Decision Aid Orientation on Risk Factor identification and Audit Test Planning, Atditing: A Joumal of Pratice and Theory, Vol. 21, No. 2, September, 2002

Beek, A., Vaassen, E.H.J., Hoofdlijnen Bestuurlijle Informatievoorziening Adwinistratieve Organisatie, Wolters-Noordhoff, Groningen, derde druk, 1999

Bell, T.B., Mars, F.O., Solomon, 1., Thonas, H. Audining Organizations Through a Strategic-Systems Lens, The KPMG Business Measurement Process, KPMG Peat Marwick LLP, 1997

Biggs, S., Bujink, W., Maijoor, S., Mock, T., Quadackers, L., Schilder, A., An Assessment of the Relevance and Respectability of Audit Research: Reflections on Reflections of Bindenga, De Acoutitont, februari, 1994

Biggs, S.F, Mock, T.J., An Investigation of Auditor Decision. Processes in the Evaluation of Intemal Controls and Audit Scope Decisions, Joursal of Accounting Research, Spring, 1983

Biggs "S.F. Mock, T.J., Watkins, P.R., Auditors" Use of Analytical Review in Audit Program Design, The Acownting Review, Vol. LXIII, No.1, January, 1988

Bindenga, A.J., Het openbar accountantsberoep als professional beroep, $M A B$, december 2000

Bindenga, A.J., Research voor Accountants, Overpeinzingen ma een Symposium, De Accountant, septenber, 1993

Blais, W., Personality Types of Controllers, Sirategic Finame, June, 2000

Blokdijk, J.H., Tests of Control in the Audit Risk Model: Effective? Efficient?, Intemational journal of Auditing, Vol. 8, 2004

Blokdijk, J.H., De toetsing van de werking van de interne controle, $M A B$, december 2002

Boer, H. der, Zutphen, L. C. wan, Business Control en Auditing ,Recente Ontwikkeling in International Verband, Academic Service, Schoonhoven, 1999

Bonner, S.E., Judgment and Decision-Making Research in Accounting, Accounting Horizons, Vol. 13, No.4, December, 1999

Bonner, S.E., Is Experience Necessary in Cue Measurement? The Case of Auditing Tasks, Contempovary Accownting Reseapth, Vol. 8, No. 1, Fall, 1991

Bonner, S.E, Experience Effects in Auditing: The Role of Task-Specific Knowledge, The Accownting Review, Vol. 65, No 1, January, 1990

Bonner, S.E. Lewis, B.L., Determinants of Auditor Expertise, Joum of Arounting Research, Vol. 28 , Supplement, 1990

Bonner, S.E., Pennington, N., Cognitive Processes and Knowledge as Determinants of Auditor Expertise, Jownal of Accounting Literature, Vol. 10, 1991

Bonner, S.E., Walker, P.L., The Effects of Instruction and Experience on the Acquisition of Auditing Knowledge, The Acounting Review, Vol. 69, No. 1, January, 1994

Boritz, J.E., The Use of Artificial Intelligence in Auditing, paper presented at the XIV World Congress of Acowntanis, Washington, October, 1992

Briggs-Myers, I., Introduction to Type, Consulting Psychologists Press, Inc, Palo Alto, 1987

Briggs-Myers, 1., McCaulley, M.H., A Guide to the Development and Use of the Meyers-Briggs Type Indicawor, Consulting Psychologists Press, Inc., Palo Alto, 1990 
Bringhurst, N.C., How Assessing Personality Type Can Benefit You and Your Patctice, Journal of Finamcial Planming, January, 2001

Brown, R.G., Objective Internal Control Evaluation, Joumal of Accomancy, November, 1962

Brown, E., Solomon, Configural Information Processing in Auditing: The Role of Domain-Specific Knowledge, The Accouting Revieu, Vol. 66 , No. 1, Jannary, 1991

Brugman, D., Van Roosmalen, M.E.P.M., Weisfelt, M.E.W., Santenvatiend Verklog wan het Onderzoek Professionele Oordelswowning, Limperg Instituut, Amsterdam, najar, 1997

Brugman, D., Weisfelt, M.E.W., The Development of Moral Reasoning and Professional judgment of Auditors' in Public Practice, De Accomtant, No. 3, november, 1993

Butt, J.L., Frequency Judgments in an Auditing-Related Task, Joumal of Accounting Research, Vol. 26, No. 2, Autumn, 1988

Chenhall, R., Morris, D., The Effect of Cognitive Style and Sponsorship Bias on the Treatment of Opportumity Costs in Resource Allocation Decisions, Accomning, Oryanizations and Saciery, Vol. 16, No. 1., 1991

Choo, $F$., Expert-Novice Differences in Judgment/Decision Making Research "Joumal of Accounting Lirerature, Vol. 8, 1989

Choo, F., Curtis, M. B., Structural Assessment in Accounting Research, Joumal of Acounting Literature, Vol. 19,2000

Choo, F., Trotman, K.T., The Relationship Between Knowledge Structure and Judgments for Experienced and Inexperienced Auditors, The Accounting Review, Vol. 66, No. 3, July, 1991

Colbert, J.L., The Effect of Experience on Auditors' Judgments, Jourwal of Accourting Literature, Vol. 8 . 1989

Commissie Corporate Governance, Corporate Gowernance in Nederland, Secretariatat Corporate Governance, Elco B.V., Amsterdam, 1997

Commissie Corporate Govemance, Aanbevelingen Inzake Conporate Govemance, Secretariat Corporate Governance, Elco B.V., Amsterdam, 1996

Committee of Sponsoring Organizations of the Treadway Commission (COSO), Enterprise Risle Maragement-Integrated Framework, AICPA, Jersey, September 2004.

Committee of Sponsoring Organizations of the Treadway Commission (COSO), Internal ControlIntegrated Frantework, AICPA, New York, September 1992.

Cruz, C.A., Understanding Neural Networks: A Primer, Cutter Information Corp., Arlington, USA, second edition, 1991

Davis, D.L., Grove, S.J., Knowkles, P.A., An Experimental Application of Personality Type as an Analogue for Decision-Making Style, Psychological Reports, 66, 1990

Davis, $\mathbb{E}$. B., Kennedy, S.J., Maines, L.A., The Relation between Consensus and Accuracy in Low-toModerate Accuracy Tasks: An Audit Example, Auditing: A Joumal of Practice \& Theory, Vol. 19, No. 1, Spring 2000

Davis, J.S., Solomon, I., Experience, Expertise, and Expert-Performance Research in Public Accounting, Joumal of Accounting Literature, Vol. 8, 1989

Doktor, R.H., F-Familton, W.F., Cognitive Style and the Acceptance of Managenent Science Recommendations, Managenent Scienc, April, 1973

Dué, R.T., The Wisdom of Patterra, CutterT Joumal, Vol, 13, No.8, August 2000

Eijkelenburg, S. van, Professional Judgment: een eigen mening?, De Accownant, Nr. 10 juni, 2001

Eilifsen, A., Knechel, W.R., Wallage, P., Application of the Business Risk Audit Model: a Field Study, accounting Horizons, Vol. 15, No. 3, September 2001

Eimers, P.W.A., Biggs, S.F., Mock, T.J., Oordeelswoming bij Cijferanalyse, Conclusies uit Cognitief Onderzoek, MAB, april,1997 
Erickson, M., Maytiew, B.W., Felix, W. L., jr, Why Do Audits Fail Evidence from Lincoln Savings and Loan, Joumal of Accounting Researh, Vol. 38 No. 1, Spring, 2000

Felix, W.L. Kimney, W.R. Jr., Research irs the Auditor's Opinion Formulation Process: State of the Art, The Accounting Review, Vol. 57, No. 2, April. 1982

Fink, D. Mewory-Judgement Audit Researdn, Work Paper, Rijksuniversiteit Limburg, Maastricht, 1995

Frederick, D.M. Auditors' Representation and Retrieval of Internal Control Knowledge, The Acconnting Review, Vol. 66, No. 2, April, 1991

Frederick, D.M, Heiman-Hoffinan, V.B., Libby, R., The Structure of Auditors' Knowledge of Financial Statement Errors, Auditing: A Journal of Prattice and Theory Vol. 13, No. 1, Spring, 1994

Frederick, D.M. Libby, R., Expertise and Auditors' Judgments of Conjunctive Events, Jourval of Accowating Researh, Vol. 24, No. 2, Autumn, 1986

Gaumnitz, B.R. Nunamaker, T.R., Surdick, JJ. Thonas, M.F., Auditor Consensus in Irternal Control Evaluation and Audic Program Planning, Joumal of Accounting Research, Vol. 20, No. $2 \mathrm{Pt}$. II, Auturnn, 1982

Gibbins, M., Propositions about the Psychology of Professional Judgment in Public Accounting, Joumal of Acconnting Research, Vol. 22, No. 1, Spring, 1984

Gibbins, M., Mason, A.K., Professional Judgment in Financial Reporting, Research Study, The Canadian Institute of Chartered Accountants, 1988

Gortemaker, J.C.A.; Bindenga, A.J., Wolde J. ten, Kollenburg, J.C.E. van, Wieleman, H.H.H., Krom, J.P.J., Dassen, R.J.M., Coster, A.J., Sluis, M.W. van, De Rol van de Acoonntant, Nu en in de Toekomst, Elsevier Bedrijfsinfontatie B.V., "s-Gravenhage, 1998

Gregory, H.J., Simmelkjaer, R.T., Comparative study of corporate govemance codes reletanit to the European Union and its mewher states, Brussel, January 2002

Groot, A.D. de, Methodologie, Grondslagen van Onderzode en Denken in de Gedragswetensichappen, Van Gorcum, Assen, 1994 (herdruk van 1961)

Hamilton, R.E., Wright, W.F., Internal Control Judgments and Effects of Experience: Replications and Extensions, Journal of Accoutting Research, Vol. 30, No. 2 Pt. II. Antunnn, 1982

Hartman, W. . Oganisatie van de Informatie-Verzorging, tweede herziene druk, Codis, Rotterdan, 1993

Hastie, R., Problems for Judgment and Decision Makng, Annual Review Psychology, 2001

Hayes, R., Schilder A., Dassen, R., Wallage, P., Principles of Auditing: An Intewational Perspective, McGraw-Hill Publishing Company, London, 1999

Holsheiner, M., Siebes A. P.J.M., Data Mining "The Searh for Knowledge in Databases, Computer Science, Department of Algoritlinuics and Architecture, Report CS-R9406, Amsterdam, January, 1994

Hunton, J.E., Wier, B., Stone, D.N., Succeeding in Managerial Accounting. Part 2: A Structural Equations Analysis, Accounting, Organizations and Society, 25, 2000

Institute of Chartered Accountants in England \& Wales, the Power of Tree, Understanding the role and relationships of infemal and extemal auditors and audit committees, $\mathbb{C A A E W}$, London, May 2003

International Federation of Accountants, Handbook of Intemationd Auditing, Asstrance, and Eehics Pronow wements, IFAC, edition 2004, New York, 2004a

International Federation of Accountants, Intewarional Education Statdard 7, Continuing Professional Dewelopwent: A Program of Longlife Leaming and Continuing Development of Professiond Competence, IFAC Education Committee, New York, $2004 b$

International Federation of Accountants, Intertational Edwcation Standards, IFAC Education Committee, New York, 2003a

International Federation of Accountants, Interwational Framework for Assurance Engagements, IFAC/IAASB, New York, $2003 \mathrm{~b}$ 
International Federation of Accountants, Intentational Standard on Asswrance Engegenents 3000, Assurance engagements other than audits or review of historial financial infornation, IFAC/IAASB, New York, $2003 c$

International Federation of Accountants, Rebuilding Public Confidence in Finawcial Reporting, aw IntematioNal Perspective, IFAC, New York, 2003d

International Federation of Accountants, Handbook 1999 Technical Pronouncements, $₫ F$ AC, edition 1999 , New York, 1999

International Federation of Accountants, Continuing Professional Education, IFAC Education Committee, New York, 1998

International Federation of Accountants, Prequalification Edwation, Assessment of Professiond Competence and Expenience Requirements of Professional Accountants, IFAC Education Committe, 1996

Jacoby, P.F., Tiger Stripes and Accontant Types. Personality Charateristics and Career Sincess in the Arcomving Profession, "The American University, Washington D.C., 1980

Jans, E.O.J, Grondslagen Administratieve Organisatie, Deel A, Samsom Bedriffilnformatie, Alphen aan den Rijn / Zaventem, 1994

Johnson, P.E., Jamal, K., Berryman, R.G., Audit Judgment Research, Acconning Organizations and Saciety, Vol. 14, Nos. 1-2, 1989

Keasey, K., Watson, R., Consensus and Accuracy in Accounting Studies of Decision-Making: a note on a new measure consensus, Accounting Organizations, and Society "Vol. 14. no 4., 1989

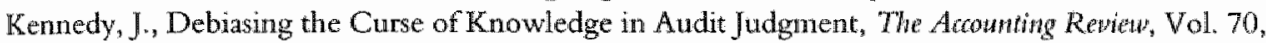
No. 2, April, 1995

Klijnsmit, P., Sodekamp, M. Wallage, P., Bedrijfrisico's van de accountant en het Audit Risk Model, $M A B$, mei 2003

Knechel, W.R., Auditing, Assurance \& Risk, South-Western College Publishing, Forida, 2001

Koning, F., Beoordeling varn de interne controle in het kader van de accountantscontrole, $M A B$, juni 2002

Kujck, J.R.H.J. van, Een pleidooi woor veld-onderzoek in auditing, enkele anknopingspunten, $M A B$, oktober, 2000

Kuijck, J.R.H.J van, Control of Judgenent Peyformance in Auditing, Vrije Universiteit Amsterdam, 1999

Lacey, A.R., Een Woordenboek van de Filosofic, Begrippen, Stromingen, Denkers, Bert Bakker, Amsterdam, 1989

Leeuwen van, $\mathrm{O}$. Wallage, P. Moderne controlebenaderingen steunen op interne beheersing, $M A B_{1}$ maart 2002

Lemon, W.M., Tatum, K.W., Turley, W.S., Developments in the audit methodologies of latge acconnting firms, Stephen Austin \& Sons LTD, Caxton Hill, Hertford, May 2000

Leonard, S., Lindsell, D., Turley, S., Improving the auditing of entities subject to common control, the Audining Practices Board, London, October 2003

Lewis, B.L., Expert Judgment in Auditing: An Expected Utility Approach, Joumal of Accounting Researd, Vol. 18, No. 2, Autumn, 1980

Lewis, B.L., Shields, M.D., Young, S.M., Evaluating Human Judgments and Decision Aids, Jourral of Accounting Research, Vol. 21, No. 1, Spring, 1983

Libby, $\mathbb{R}$., The Role of Knouledge and Mennory in Audit Judgment, Judgment and Decision-Making Research in Accounting and Auditing, Cambridge University Press, New York, 1995

Libby, R. Artman, J.T., Willingham, J. J, Process Subceptibility, Control Risk, and Audit Planning, The Accounting Review, Vol. LX, No. 2, April, 1985

Libby, R., Frederick, D.M., Experience and the Ability to Explain Audit Findings, Joumal of Aconnting Research, Vol 28, No. 2, Autumn, 1990 
Libby, R., Hun-Tong Tan, Modeling the Determinants of Audit Expertise, Accounting, Organizations and Society, Vol. 19, No. 8, Pergamon Press, 1994

Libby, R, Lewis, B.L., Human Information Processing Research in Accounting: The State of the Art, Acrounting, Organizations and Society, Vol. 2, No. 3, Pergamon Press, 1977

Libby, R, Libby, P.A., Expert Measurement and Mechanical Combination in Control Reliance Decisions, The Acowning Review, Vol. LXIV, No. 4, October, 1989

Libby, R., Lipe, M.G., Incentives, Effort, and the Cognitive Process Involved in Accounting-Related Judgments, Jounal of Accounting Research, Vol. 30, No. 2, Autumm, 1992

Liblyy, R, Luft, J., Determinants of Judgment Performance in Accounting Settings: Ability, Knowledge, Motivation, and Environment, Accounting, Organizations and Society, Vol. 18, No. 5, 1993

Limperg Institutut, Risico's en Oordeelsworming in de Accountantspraletijk, Limperg Instituut, Amsterdan, augustus, 1.990

Lloyd, P., Goldschmidt, P., Modelling Audit Risk assessments: Exploration of an Alternative to the Use of Knowledge-based Systems, International Jownal of Auditing, Vol. 7, 2003

MacDonald, A.P., Jr., Revised Scale for Ambiguity Tolerance: Reliability and Validity, Psychological Reports, 1970

Maijoor, S., Meuwissen, R., Quadackers, L., Accounting in Europe, The Effects of National Institutions on Audit Research: Evidence from Europe and North America, The European Accounting Review, 2000, 9:4

Majoor, G.C.M. , Gezag van Richtlijnen voor de Accountantscontrole, Eburon, Maartensdijk, mei, 1997

Marchant, G., Discussion of Determents of Auditor Expertise, Joumal of Accounting Researd, Vol. 28, Supplement, 1990

Mascha, M.F., Miller, C.L., The Effect of Task Complexity and a Decision Aid on Decision Accuracy, Conserysus, and Efficiency, unpublished study, September 2000

Masuch, M., LaPotin, P., Beyond Garbage Cans: An AI Model of Organizational Choice, Administrative Science Quarterly, March, 1989

Mayper, A.G., Consensus of Auditor's Materiality Judgments of Internal Accounting Controls Weaknesses, Joumal of Accounting Research, Vol. 20, No. 2, Autumn, 1982

Mayper, A.G., Doucet, M.S., Warren, C.S., Auditor's Materiality Judgments of Internal Accounting Control Weaknesses, Auditing: A Journal of Practice \& Theory, Vol. 9. No. 1, Fall, 1989

Meixner, W.F., Welker, R.B., Judgment Consensus and Auditor Experience: An Examination of Organizational Relations, The Acionming Rewiew, Vol. LXIII, No. 3, Jully, 1988

Meservy, R D., Bailey Jr., A.D., Johnson, P.E., Internal Control Evaluation: A Computational Model of the Review Process, Auditing: A Joumal of Pratice \& Therr, Vol. 6, No. 1 Fall, 1986

Minsky, M., The Soriety of Minds, Sinon and Schuster, New York, 1986

Mock, T.]., Turner, J L., Intemal Acconntivg Control Esolwation and Auditor Judgment; An Anthology, Garland Publishing Inc, New York and London, 1999

Mouthaan, H.J., Corporate Governance: de verantwoordelijkheid woor het intemal control systen, Tijdschiff woor Bedrifsadwinistratie, 105e jaargang, maart, 2001, nummer 1240

Mouthaan, H.J., Corporate Govemance de verantwoordelijkheid voor het internal control system en het Rapporteren terzake, Leiden, september 2000

Nederlands Institunt van Registeraccountants, Richtlijnen yoor de Acountantscontrole, Editie 2002, maart, 2003

Nederlands Irstituut van $\mathbb{R}$ egisteraccountants, Accountantscontrolerisico, NIVRA-geschrift mamwer 49, Kluwer Bedrijfswetenschappen, Deventer, september, 1989

Nederlands Instituut van Registeraccountants, Vakkundige Oordeelsvorning van de Accountant, NIVRA-geshrift numwer 41, Kluwer Bedrijfswetenschappen, Deventer, mei, 1986 
Newell, A., Unified Theories of Cognition, Harvard University Press Cambridge, Massachusetts, London, England, 1994

Nieuwelaar, M.J.J. van den, Vaassen, E.H., Beheersing van de Postmoderne Organisatie, Tyjdshtiff poor Bedriffsadministratie, 105 e jaargang, maart, 2001 nummer 1240

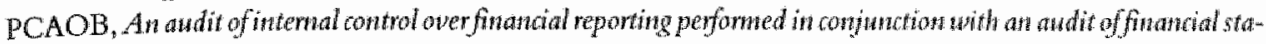
tements, PCAOB, Washington, March, 2004

$\mathrm{PCAOB}$, Briefing paper for the roundtable on reporting on intenal control, $\mathrm{PCAOB}$, Washington, $\mathrm{March}$, 2003

Peecher, E., Solomon, 1., Theory and Experimentation in Studies of Audit Judgments and Decisions: Avoiding Common Research Traps, International Jowmal of Auditing, Vol. 5,2001

Pincus, K.V., Audit Judgment Consensus: A Model for Dichotomous Decisions, Auditing: A Joumal of Pratice E Theory, Vol. 9, No. 2, Spring, 1990

Poel, J.H.R. van de, Judgment and Control; Hudividual and Organizational Aspects of Performance Evaluation, Wolters-Noordhoft B.V., Groningen, 1986

Poel, J.H.R. van de, Vaassen, E.H.J., Andit Judgment Researd, Accountantscontrole en Menselijke Beslissingsprocessen, Research Memorandum, Rijksuniversiteit Limburg, RM 88-033, december, 1988

Public Oversight Board, The Panel on Awdit Effectiveness, Exposure Draft, May 31, 2000

Roberts, M.L., Dillard-Eggers, J., A Cognitive Task Andysis Approach to Understawding the Acquisition of Audit Kuowledge, University of Alabama and Belmont University Nashville, November 2003

Rosch, E., Principles of Catcgorization, in Cognition and Categorization, $28-48$ Hillsdale, NJ: Lawrence Erlbaum, 1978

Rydell, S.T., Tolerance of Ambiguity and Semantic Differential Ratings, Psychological Reparts 1966, Southern Universities Press, 1966

Rydell, S.T', Rosen, E., Measurement and Some Correlates of Need-Cognition, Pyycholngical Reports 1966, Southern Universities Press, 1966

Sarbanes-Oxley Act of $2002107^{\text {th }}$ Congress $2^{\text {nd }}$ session, house of representatives, F:P7MACTREFH3763 CR.HSE, July, 2002

Schachner Chanen, J., Try a Little Typecasting Tests helps define Personality Traits compatible with Solo Practice, $A B A$ Jounal, November, 2000

Schilder, A., Na 100 Jaar Opnieuw? De Functie van de Accountant, De Accountamt, No. 3, november, 1994

Schilder, A., Risico-Analyse: Rekemmodel, Denkmodel of Wedstrijdnodel? Een Nabeschouwing van een Boeiend Debat, De Accountant, No. 9, mei, 1991

Schloemer, P.G., Schloemer, M.S., The Personality Types and Preferences of CPA Firm Professionals: An Analysis of Changes in the Profession, Accounting Horizons, December, 1997

Schwarz, C.A., Corporate Governance, Een Themanummer, Tijdsdhiff wor Bedriffodministratic, Jaargang 102, Nummer 1231, juni, 1998

Scott, W.R., The State of the Art of Academic Research in Auditing, Joumal of Accounting Liferame, Vol. 3, 1984

Shelton, S.W., The Effect of Experience on the Use of Irrelevant Evidence in Auditor Judgrnent, The Accouting Review, Vol. 74, No, 2, April, 1999

Slotboom, A., Siatistiek in woorden, De meest voorkomende termen en technieken, Wolters Noordhoff, Grow ningen, tweede druk, 1996

Soeting, R., Spoor, L., COSO na 10 jaar, AO na 100 jaar, MAB, september 2003

Solomon, I., Shields, M.D., Judgment and Decision-Making Research in Auditing, Judgunent and Decision-Making Restarch in Acounting and Auditing, Cambridge Unversity Press, New York, 1995

Starreveld, R.W., Mare, H.B. de, Joels, E.J., Bestwurlijte Informatheverzorging deel 1 Algennene Grondslapen, Samsom Alphen aan den Rijn / Brussell, vierde druk, 1997 a 
Starreveld, R.W., Mare, H.B. de, Joels, E.J., Bestuwrlyke Informatieverzorging deel $2 b$ Toepassingen, Typologie vati de Bedrifshuishoudingen, Samsom Alphen aan den Rijn / Brussel, wierde druk, 1997b

Starteveld, R.W., Leer wat de Administratieve Onganisatic, Samsom Alphen aan den Rijn / Bnussel, 1962

Swighem ${ }_{\text {, }}$. van, Bestumrlijle lifforwatieverzonging, Academic Service, Addison-Wesley, Schoonhoven, 1987

Swinkels, W, Tone at the Top, consistentie twssen woorden en daden wan het mantagement, Kluwer, Deventer, augustus 2003

Tabaksblat, M., De Nederlandse corporate govenuancecode. Beginselen wan dengdelijk ondervemingsbestuur en best practice bepalingen, december, 2003

Tabor, R.H., Internal Control Evaluations and Audit Program Revisions: Some Additional Evidence, Joumal of Accounting Rescarch, Vol. 21, No. 1, Spring, 1983

Tamboer, $T_{j}$, Professionalisering wan vrije beroepen, MAB, Decenber 2000

Tan, $\mathrm{H} . \mathrm{T}, \mathrm{KaO}_{2}$ A. Accountability Effects on Auditors' Performance: The Influence of Knowledge, Problem-Solving Ability, and Task Complexity, Jounal of Acromning Resarch, Vol. 37, No. 1, Spring, 1999

Trotman, K T., Design issues in Audit DM Experiments, International Joumal of Auditing, Vol 5, 2001

Troman, K.T. The Review Process and the Accuracy of Auditor Judgments, Joumal of Accounting Researth, Vol. 23, No. 2, Autumn, 1985

Trotman, K.T., Yetton, P.W., The Effect of the Review Process on Auditor Judgments, Jourral of Accousting Rescarch, Vol. 23, No. 1, Spring, 1985

Trotman, K.T., Wood, R., A Meta-Analysis of Studies on Internall Control Judgments, Joumal of Accounting Researh, Vol 29, No.1. Spring, 1991

Tubbs, R.M., The effect of experience on the Auditor's Organization and Amount of Knowledge, The Accownting Review, Vol. 67. No. 4, October, 1992

Turnbull, Internal Control-ghidance for directors on the Combined Code, ICAEW, London, 1999

United Nations, Integrating Enwironmemtal asd Financial Peyformance at the Enterprise Level, a Methodology for Standardizing Eca-efficiency Indicators, New York and Geneva, 2000

University of Florida, Isabel Briggs Myers Papers, Manwcript Group 64, Tim Petit, Spring, 1998, Revised $9 / 20 / 2000$, http //web.uflib.ufledu/spec/manuscript/guides/Myers.hem

Vaassen, E.H.J. Auditors' Decision Processes in Audh Planning Stage Materiality Judgments, Universitaire Pers Matastricht, 1994

Vaassen, L.H.J., An Onemieu of Akdit Judgmen Researh, Research Menonandum, Rijksuniversiteit Limburg, 1993

Vaassen, E.H.J., Beek, A., Administratieve Organisatie in Intemationaal perspectief, het enige verschil is de naam van het vak, Tijdshrift woor Bedrifsadministratic, $101 \mathrm{e}$ jaargang, maart, nummer 1203, 1997

Vaatstra, H.F., Expertise in Accountancy, Universicaire Pers Maastricht, 1996

Waller, W.S., Decision-Making Research in Managerial Accounting: Return to Behavioral-Economics Foundacions, Jadgment and Decision-Making Research in Accounting and Anditing, Cambridge University Press, New York, 1995

Wheeler, P., The Myers-Briggs "Type Indicator and Applications to Accounting Education and Research, Accomting Efucation, Vol. 16, No.1, February, 2001

Wilschut, K.P.G., Accountantscontrolerisico en Bedrijfsrisico, De Accountant, No. 2, oktober, 1997

Winter, J., Garrido Garcia, J.M., Hopt, K.J., Rickford, J, Rossi, G, Schans Christensen, J., Simon, J., Report of the high level group of company law expents on a modern regulatory framework for company law in Europe, Brussel, 4 november 2002

Wright, M.E., Davidson, R.A., The Effect of Auditor Attestation and Tolerance for Ambiguity on Conmercial Lending Decisions, Auditing: A Joumal of Practice \& 'Theory, Vol. 19, No. 2, Fall, 2000 
Wright, W.F., Self-Insight into the Cognitive Processing of Financial lnformation, Accownting, Onganizations and Saciety, Vol. 2, No. 4, Pergamon Press, 1977

W/u, B.K. H., Roebuck, P., Fargher, N., A Note on Auditors" Perception of Business Risk, Intewational Jourytal of Auditing, Vol. 6, 2002

Zebda, A., Fuzzy Set Theory and Accounting, Joumal of Accounting Literature, Vol. 8, 1989

Zwaan, A.H. van der, Organisatie Onderzoek Leerboek voor de Praktijk: Het Ontwerpen wan Onderzoek in Organisaties, Van Gorcum, Assen/Maastricht, tweede druk, 1992. 


\section{Bijlagen}

Bijlage 1: Data model ........................ 204

Bijlage 2: Demografische gegevens, de vragenlijst........... 205

Bijlage 3: Beheersingsinstrumentarium, de vragenlijst . . . . . . . 208

Bijlage 4: Myers Briggs type indicator, de vragenlijst. . . . . . . . . . 209

Bijlage 5: Ambiguity tolerance indicator, de vragenlijst . . . . . . 214

Bijlage 6: Personeelszakenproces, de casusstelling . . . . . . . . . 215

Bijlage 7: Deelprocessen, procedures, activiteiten en beheersing . . . . 228

Bijlage 8: Overzicht casusstellingen met aanwezige beheersingsmaatregelen 231

Bijlage 9: Myers-Briggs type indicator, een leeswijzer ........ 233

Bijlage 10: Overzicht beoordeelde casusstellingen. . . . . . . . 239

Bijlage 11: Verdeling 'Voorkompercentages' per casusstelling . . . . . . . 240

Bijlage 12: Overzicht beoordeelde casusstellingen en beheersingsmaatregelen 241

Bijlage 13: Overzicht gegeven waardeoordelen en consensuswaarden . . . 242

Bijlage 14: Overzicht gegeven waardeoordelen, diverse dwarsdoorsneden . . 244

Bijlage 15: Verdeling waardeoordelen per ervaringsjaren en beoordelingswaarden . . . . . . . . . . . . . 246

Bijlage 16: Verdeling waardeoordelen per beheersingsmaatregel en beoordelingswaarden . . . . . . . . . . . . . . 248

Bijlage 17: Verdeling waardeoordelen per voorkompercentage en beoordelingswaarden . . . . . . . . . . . . . . . 250

Bijlage 18: Verdeling waardeoordelen per voorkeur en beoordelingswaarden 252 
Bijlage 19: Verdeling waardeoordelen per MBTI type en beoordelingswaarden . . . . . . . . . . . . . 254

Bijlage 20: Verdeling waardeoordelen per ambiguiteitwaarde en beoordelingswaarden . . . . . . . . . . . . . . 256

Bijlage 21: Verdeling waardeoordelen per mate van weerspiegeling en beoordelingswaarden . . . . . . . . . . . . . . 258

Bijlage 22: Verdeling waardeoordelen conform voorkeur en beoordelingswaarden . . . . . . . . . . . . . . . 2 260

Bijlage 23: Verdeling waardeoordelen zonder voorkeur en beoordelingswaarden. . . . . . . . . . . . . . . 262

Bijlage 24: MBTI indicatoren van 143 accountants volgens CAPT . . . . 264

Bijlage 25: MBTI indicatoren van 143 accountants en 89 consultants volgens CAPT . . . . . . . . . . . . . . 266

Bijlage 26: MBTI uitkomsten van 1181 accountants volgens diverse onderzoeken . . . . . . . . . . . . . . . . . . . 267

Bijlage 27: MBTI indicatoren van 199 accountants volgens huidig onderzoek. . . . . . . . . . . . . . . . . . . . . . . . . 268

Bijlage 28: MBTI indicatoren huidig onderzoek versus CAPT en overige onderzoeken . . . . . . . . . . . . . . . . . . . . . 269 


\section{Bijlage 1: Data model}

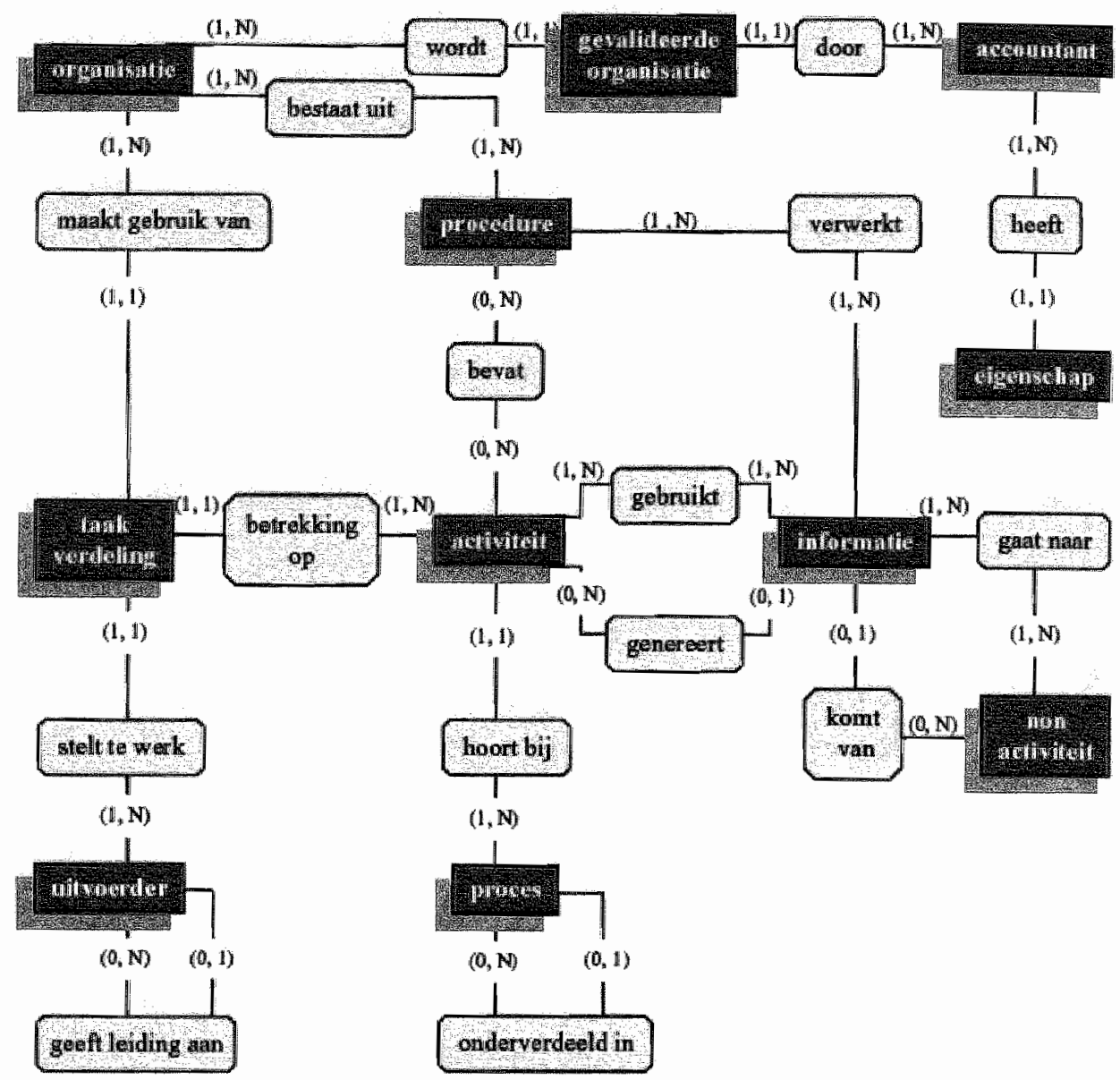




\section{Bijlage 2: Demografische gegevens, de vragenlijst}

\section{Belangrijke data}

\begin{tabular}{|l|c|c|c|}
\hline omschrijving & dag & maand & jaar \\
\hline Datum van invullen wan deze vragenlijst & & & \\
\hline Uw geboortedatun & & & \\
\hline Begindatum van uw werkzame leven & & & \\
\hline Werkzaam binnen accountancy: vanaf & & & \\
\hline \multicolumn{1}{|c|}{ tor } & & & \\
\hline
\end{tabular}

\section{Overige belangrijke gegevens}

\begin{tabular}{|c|c|c|c|c|c|c|c|}
\hline \multicolumn{8}{|l|}{ In welk land bent u geboren } \\
\hline Uw geslacht & \multicolumn{3}{|l|}{$\operatorname{man}$} & \multicolumn{4}{|l|}{ vroum } \\
\hline \multicolumn{8}{|l|}{$\begin{array}{l}\text { Vestigingsplaats, kantoor/bedrijf, van } \\
\text { walruit uw werkzaamheden nu worden } \\
\text { verricht }\end{array}$} \\
\hline $\begin{array}{l}\text { Aantal wisselingen van werkgever danwel } \\
\text { van kantoor bij dezelfde werkgever }\end{array}$ & $\begin{array}{c}\text { eerste } \\
\text { kantoor }\end{array}$ & $1 x$ & $2 \mathrm{x}$ & $3 x$ & $4 x$ & $5 x$ & $\begin{array}{r}75 \mathrm{x} \\
\text { wissel } \\
\end{array}$ \\
\hline $\begin{array}{l}\text { Hoeveel gekwalificeerde accountants zijn } \\
\text { werkzaam binnen uw kantoor }\end{array}$ & 1 & $2-5$ & $6-10$ & $11-25$ & $26-100$ & & 100 \\
\hline Momenteel werkzaam als & \multicolumn{7}{|c|}{$\begin{array}{l}\text { Openbaar accountant } \\
\text { Overheidsaccountant } \\
\text { Interne accountant } \\
\text { Finad-sector'. } \\
\text { Onderwijs } \\
\text { Niet actief } \\
\end{array}$} \\
\hline In vorige functie werkzam als & \multicolumn{7}{|c|}{$\begin{array}{l}\text { Openbar accountant } \\
\text { Overheidsaccountant } \\
\text { Interne accountant } \\
\text { Finad-sector } \\
\text { Onderwijs } \\
\text { Niet actief } \\
\end{array}$} \\
\hline $\begin{array}{l}\text { Afgestudeerd alls registeraccountant c.q. } \\
\text { Accountant Administratieconsulent }\end{array}$ & \multicolumn{7}{|c|}{$\begin{array}{l}\text { NIVRA-opleiding: } \\
\text { Nijenrode } \\
\text { Universitari } \\
\text { NOvAA-opleiding } \\
\text { HEAO } \\
\text { Buitenlandse opleiding }\end{array}$} \\
\hline $\begin{array}{l}\text { Welke andere universitaire of Hbomoplei- } \\
\text { ding heeft } u \text { gevolgd. }\end{array}$ & & & & & & & \\
\hline
\end{tabular}

1. Werkzaam als directeur, controller, administrateur, bedrijfseconoom, etc 
Alleen in te wullen indion ts werkzaam bent als openbaat accountant.

Verdleling wan uw portefeuille naar klant soort

\begin{tabular}{|l|c|}
\hline Samenstelling klantenportefeuile & Aanceel in aw klantenportefeuille \\
\hline Handel & $\%$ \\
\hline Irdustrie & $\%$ \\
\hline Agrarische bedrijver & $\%$ \\
\hline Dienstverlening & $\%$ \\
\hline Financiele instellingen & $\%$ \\
\hline Rijksoverheid & $\%$ \\
\hline Laggere overbed & $\%$ \\
\hline Stichtingen en verenigingen & $100 \%$ \\
\hline Totaal & $\%$ \\
\hline
\end{tabular}

Verdeling van uw portefeuille naar kdantgrootte

\begin{tabular}{|l|c|}
\hline Klankgroote & Aande lin uw klantenportefenille \\
\hline $0-10$ werknemers & $\%$ \\
\hline $11-100$ werknemers & $\%$ \\
\hline $101-250$ werknemers & $\%$ \\
\hline $251-1000$ werknemers & $\%$ \\
\hline$>1000$ werknemers & $100 \%$ \\
\hline Total & $\%$ \\
\hline
\end{tabular}

Verdeling van uw portefeuille natar type opdracht

\begin{tabular}{|l|c|}
\hline Type opdrachten & Aanded in totale klanterportefeuille \\
\hline Controleopdrachten & $\%$ \\
\hline Samenstelopdrachten & $\%$ \\
\hline Becordelingsopdrachten & $\%$ \\
\hline Advies opdachten & $\%$ \\
\hline LDP-audir opdrachten & $\%$ \\
\hline Milieu-audit opdrachten & $\%$ \\
\hline Operational-audit opdrachten & $\%$ \\
\hline Overige opdrachten, $\mathrm{nl}$ & $\%$ \\
\hline Overige opdrachten, $\mathrm{nl}$. & $\%$ \\
\hline Overige opdrachten, $\mathrm{nl}$ & $\%$ \\
\hline Totial & $100 \%$ \\
\hline
\end{tabular}


Alleen in te vullen als u doceert

\begin{tabular}{|c|c|}
\hline \multicolumn{2}{|l|}{ Sinds warneer doceert u (allieen jaar) } \\
\hline In welk vakgebied doceert u & $\begin{array}{l}\text { Controlelet } \\
\text { Administratieve Organisatie } \\
\text { EDP-auditing } \\
\text { Milien-auditing } \\
\text { Operational-anditing } \\
\text { Overige, nl: }\end{array}$ \\
\hline Aan wellk onderwijs instituut doceert u & $\begin{array}{l}\text { NIVRA-opleiding } \\
\text { Nijenrode } \\
\text { Universitatr } \\
\text { NOVAA-opleiding } \\
\text { HEAO } \\
\text { Buitenlandse opleiding }\end{array}$ \\
\hline
\end{tabular}




\section{Bijlage 3: Beheersingsinstrumentarium, de vragenlijst}

Onderstaande tabel geeft een vijftal soorten beheersingsmaatregelen weer welke door het management gehanteerd worden om bedrijfsprocessen te kunnen beheersen.

Kunt $\mathrm{u}$ in eert ranking van 1 (belangrijkst) tot 5 (minst belangrijk) angeven wat naar uw mening de belangrijkheidvolgorde zou moeten zijn van deze instrumenten bij ber beheersen van processen.

U mag slechts één cijfer per onderdeel geven waarbjj ieder cijfer maar éẻn maal gebruikt mag worden.

\section{Beheersingsinstrumentarium}

\begin{tabular}{|l|lllll|}
\hline $\begin{array}{l}\text { Procesbeheersing: } \\
\text { zoals interne beheersingsmaatregelen in het proces zelf }\end{array}$ & 1 & 2 & 3 & 4 & 5 \\
\hline $\begin{array}{l}\text { Financiele beheersing: } \\
\text { zoals budgettering }\end{array}$ & 1 & 2 & 3 & 4 & 5 \\
\hline $\begin{array}{l}\text { Organisatorische beheersing: } \\
\text { zoalls functiescheiding }\end{array}$ & 1 & 2 & 3 & 4 & 5 \\
\hline $\begin{array}{l}\text { Informatiebeheersing: } \\
\text { zoals standenregisters }\end{array}$ & 1 & 2 & 3 & 4 & 5 \\
\hline $\begin{array}{l}\text { Prestatiebeheersing: } \\
\text { zoals productregistraties en ziekteverzuin }\end{array}$ & 1 & 2 & 3 & 4 & 5 \\
\hline
\end{tabular}




\section{Bijlage 4: Myers Briggs type indicator, de vragenlijst}

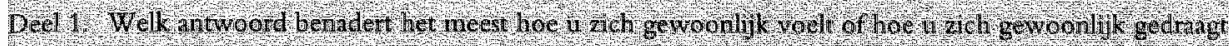

1 Als ut een dagje ergens mar toe gaat bent u dan geneigd

A te plannen wat u wilt doen en wanneer

B te gan an zien hoe het vitkomt

2 Als u een leraar zon zijin wat wilt u dan thet liefst onderwijzen

A praktische wakken

$B$ theoretische vakken

3 Bent u gewoonlijk

A iemand die zich gemakkelijk arashun

B tamelijk rustig en gereserveerd.

4 Geeft u er de voorkeur an

A afspraken, feesten etc. ruim van te voren vast te leggen

B vij te zijn om te kiezen wat w leuk windt als het zover is

5 Kunt u gewoonlijk meer opschieten met

A Gantasierijke mensen

$B$ realistische mensen

6 Wat doet u vaker
A urw hart laten spreken
B uw verstand laten spreken

7 Als u in een groep mensen zit zou u dan eerdier

A u mengen in een gesprek van de groep

B mar met een persoon tegrelijk praten

8 Bent u beter in

A snel reageren op onverwachte dingen

$B$ het volgen wan cen zorgvildig uitge wertkt plan

9 Wilt u liever gezien worden als
A een praktisch mens
B een vindingrijk mens
A Introduceert $u$ in een groep walk anderen

B wotdt watk geintroduceerd.

Heeft u mear bewondering voor mensen die

A gewoon onopvallend zijn en niet de aandacht trekken

B zo origimeel en individualistisch zijn dat ze zich er niets van antrekken of ze in het oog lopen of niet 

A trekt u dat an
$\mathrm{B}$ beriauwi u

A diepe wriendschappen met exy par mensen.

B Jostere wiendschappen met veel verschillendie mensen

14. He⿱ idee on een lijst te maken wan wat u zou moeten doen in een weekend
A redat uan
B laat u komd
C makt w sacherignig

15 Is het een groter compliment voor ty orn betiteld te worden als
A exin gevoelsmers
$B$ een verstandsmens

\section{Bent u onder wrienden}

A één van de laatste die te horen krijgt wat er gebeurt

B weet $u$ altijd precies hoe het met iedereen gaxt

(alleen bij deze vragg twee antwoorden geven als ze beide war zijn)

17 In uw dagelijkse werk
A vindt $u$ ean haastige opdracht wel leak zodat u tegen de klok moet werken
$B$ heeft $u$ er een thekel an onder druk te werken
C plant u ww werk gewoonlijk zo dat u miet onder druk hoeft te werken

18 Wilt u liever ienand als vriend hebben
A die allijd nieuwe ideeern heeft
B dite met beide voeten op de grond stat

19 A Praat u gemakkelijk met bijna iedereen zolang het gewenst is

B theeft a allieen gesprekstof genoeg bij bepaalde mensen of onder bepralde omstandigheden

20 Als a een specialle opdrache moet doen wilt wi dan liever

A thet zorguldig onganiseren voordat a begint

B. ontdekken wadig is als u bezig bent

21 Vindt $u$
A gevol belangujker dan logica
B logica belangrijker dan gevoel

22 Als a voor un plezier leest

A geniet $\mathrm{u}$ dan meer van vreende of originele uitdrakkingswijzen

B. houdt u meer van schrijven die precies zeggen wat ze bedoelen

23 Kumnen nieuwe mensen dis u ormoet

A al gaw vertellen wat u in geinteresseerd bent

B pas vertellan warin u geinterescerd bent als ze u erg goed kenner 
Als thet van tevoren vaststaxt dat u een bepalde task op en wastgestelde tijd moet doen vindt u het dan
A pretrig om in staat te zijn het ook zodanig te planmen
$B$ ren beetje onplezierig on zo vastgellegd te zijn

25 As w iets doet wat ook ved andere mensen down the fo dan de neiging

A om het op exn gangbare manier te doen
B een eigen manier te ontdekken

26 Is het gewoonlijk zo

A dat unw gevoelens openlijk toont.

$B$ dat u uw gevoelens woor u houdt

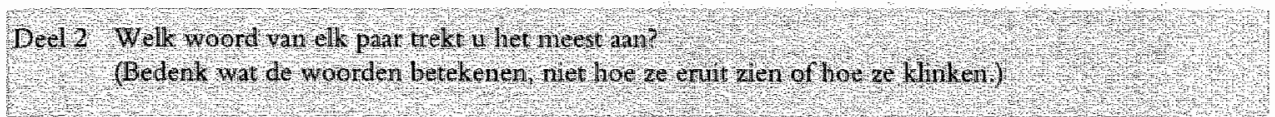

\begin{tabular}{|c|c|c|c|}
\hline 27 & A planmatig & $B$ & toevallig \\
\hline 28 & A rriendelijk & $B$ & resoluut \\
\hline 29 & A fienten & $\mathrm{B}$ & denkbeelden \\
\hline 30 & denkend & $\mathrm{B}$ & woelend \\
\hline 31 & A joviaal & $B$ & kalm (rustig. stil) \\
\hline 32 & A overtuigend & $\mathrm{B}$ & ontroerend \\
\hline 33 & bewering & $\mathrm{B}$ & begrip \\
\hline 34 & analyseren & $\mathrm{B}$ & sympathe voor voelen \\
\hline 35 & systematisch & $\mathrm{B}$ & spontaan \\
\hline 36 & reclutvardigheid & B & barmhartigheid \\
\hline 37 & weraghoudend & $\mathrm{B}$ & sprankzaam \\
\hline 38 & deernis (medelijden) & $\mathrm{B}$ & voorutitzien \\
\hline 39 & systematisch & $\mathrm{B}$ & bij toeval \\
\hline 40 & $\mathrm{kalm}$ & $\mathrm{B}$ & levendig \\
\hline 41 & woorrecht & B & gunst \\
\hline 42 & A theoric & $\mathrm{B}$ & zekerheid \\
\hline 43 & beslissend & $B$ & toegewijd \\
\hline 44 & letterlijk & B & Ggumlijk \\
\hline 45 & standvastig & $B$ & barteligk \\
\hline 46 & fantasierijk & $\mathrm{B}$ & bij de feiten houdend \\
\hline 47 & verzoener & $\mathrm{B}$ & rechiter \\
\hline 48 & vervaardigen & $B$ & ontwerpen \\
\hline 49 & zacht & $\mathrm{B}$ & hard \\
\hline 50 & waancenbaar & $\mathrm{B}$ & betoverend \\
\hline 51 & wergeven & $\mathrm{B}$ & verdragen (tolereren) \\
\hline 52 & productie & $B$ & ontwerp \\
\hline 53 & opwelling (impuls) & $B$ & besluitraardigheid \\
\hline 54 & wite & $\mathrm{B}$ & Wat \\
\hline 55 & spreken & B & schrijver \\
\hline 56 & onkritsch & $\mathrm{B}$ & kritischn \\
\hline 57 & punctueel & $B$ & op low gemak \\
\hline 58 & A concreet & $B$ & abstract \\
\hline 59 & veranderend & $B$ & blijvend \\
\hline 60 & op zijn hoede & $\mathrm{B}$ & goed wan vertrouwen \\
\hline 61 & A maken (bouwen) & B & verzinnen (uitvinden) \\
\hline 62 & ordelyk (opgentind) & $\mathrm{B}$ & nonchalant \\
\hline 63 & A basis & $B$ & top \\
\hline 64 & A snel & $B$ & zorgvuldig \\
\hline
\end{tabular}




\begin{tabular}{|c|c|c|c|}
\hline 65 & A theorie & $\mathrm{B}$ & emaring \\
\hline 66 & atirdig & $B$ & gereserveerd \\
\hline 67 & teken (afbeelding) & B & symbool \\
\hline 68 & A reteste & $B$ & schouwburg \\
\hline 69 & A accepteren & B & veranderen \\
\hline 70 & A instemumen & B & bediscussierren \\
\hline 7 & A bekend & $B$ & onbekend \\
\hline
\end{tabular}

72 Wilt wan jezelf zegren dat a in verhouding tot de gemiddelde mens

A earter warm loopt voor dingen

13 minder gaw wam loopt voor dingen

73 Vindt u het erger on

A onsympativek te zijn

B ontedalijk te zilin

74 Bent u

A nogal geneigd om dingen op her larste moment te doen

B werkt het u op ux zenwwen: on dingen op het laatste moment te doen

75 A Vervedt uzich wel eens op feestjes

$B$ heef u op feestjes altijd wel plezier

76 Vinde u het habben van dageljikse routine

A een pretrige manier om de dingen te laten verlopen

B lastig, zelfs al is het noodzakelijk

77 Als er iets nieuws in de mode komt, bent u dan gewoonlijk

A cén van de eersten on het te proberen

B rivet zo geinteresserd

78 Als u denkwan een kleingheid die a eigenlijk moet doen of kopen

A verget a het dan wak wer ean hele tijd

D schriju w het op een briefe om eran te denken

C doet w het zonder gehetigensteuntje

Is het

A genakkelijk onu u te leren kenmen

$B$ moeilijk om u te leren kennen

80 Geeft u or in aw lewenstijl de voorketur an om

A ontigined ta zijn

B conventioneel te zijn

81. Wat doet u gewoonlijk wanneet" u zich in een pijnlijke situatie bevindt

A van ondentwerp veranderen

$B$ een grapje erviun maken

C dagen later bedenken wat a had moeten zeggen 

A een routine
$B$ ean voorturende verandering

83 Het is een groter compliment wan lemand te zeggen dar hij

A visie heeft

$B$ verstand heett

84 Als $\mathbf{n}$ begint an een opdracht waar $\mathrm{u}$ een hele week woor nodig ha f
A neent u de tijd om en lijgt te maken om de afronderlijke taken in de wolgorde waarin ze gedaan moeten worden te zetten
B stort u zich erin

85 Denkt u dat het belangrijker is in stat te zijn

A de verschillende mogeligheder in teen situatie te zien

B $u$ ana te passen an de gegeven feiten

86 Denkt $u$ dat de mensen uit uw nabijheid weten wat u vindt (how w stat to.v.)
A wan de meeste dingen
$B$ alleen als u cen speciale reden had on thet hen te vertellen.

87 Wilt u hever werken onder iemand die
A altijd vriendelijk (aandig) is
$B$ altijd eerlijk is

88 Als er een opdracht gedaan moet worden, zorgt u ervoor

A bijtrids te beginnen zodat u eventueel tijd over heef

$B$ rekent $u$ op de extra snelheid die $u$ op het latst ontwikkelt

Denllet $u$ dat het erger is
A teveel warmie te tonen
$B$ nitet genoeg warmte te tonen

90 Als u op een feestje bent vindt u het dian leuker om (houdt a er mear van)
A te helpen dat het goed loopt
$B$ jeder zich op zijn manier te laten amuseren

91 Willt u eerder
A de geijkte methode on iets goed to doen, ondersteunen
$B$ analyseren wat er nog fout is en onopgeloste problemen anpakken

Gaat u zorgvuldiger om met

A de gevoelens varu mensen

B de rechten van menseri

93 Als iemand un op zaterdagochtend vrage wat w die dag gaat doem. will u dan
A in staat zijn het ongeveer te zeggen
B twee keter zoveel dingen opnoemen
C afwachten en he bekijken

94 Vindt w a de routine van de dag
A rustgevend, of
$B$ vervelend 


\section{Bijlage 5: Ambiguity tolerance indicator, de vragenlijst}

Bent u het eens of oneens met onderstande witspraken?

Omaikel thet antwoord van uw keuze. Denk niec te lang na, er zijn geen juiste en orjuiste antwoorden

1 As u wermoedt dat cen bepasld probleen geen oplossing heeft, vindt u het niet de noeite waard er verder aandacht aan te schenken.

2 Bij mensen die uniek begrijpt, voelt u zich nooit helemaal op uw gemak.

Eens Oneens

3 Vrijwel alles kan op een juiste of onjuiste manier gedaan worden.

Eens Oneens

4 U doer liever mee an een loterij met kleine knsen op hoge prijzen, dan

4 U doet liever mee aan een loterij met kleine kansen op hoge prijzen, dan een anet grote kansen en lage prijzen.

5 Om een complex probleem te begrijpen, moet $u$ het in zijn ruimere context zien in plasts van het in kleine stukjes uireen te rafelen.

6 U voelt zich belhoorlijk onzeker als u zich in een siruatie bevindt die u niet kunt beinvloeden.

7 Praktischi ieder probleem heeft een oplossing.

Eens

Oneens

Eens

Oneens.

Eens

Oneeus

Eens

Oneens

$8 \mathrm{U}$ windt het vervelend als $\mathbf{u}$ de gedachtegang van iemand anders niet kunt volgen.

9 U bent er wan overtuggd dat er altijd een scherp onderscheid te maken is tussen 'goed' en 'slecht'.

10 Wanneer un niet weet hoe anderen op k reageren, kunt u daar behoorlijk over inzitten.

11 Als u zich njet aan een par basisregels houdt, makt u in deze wereld niets klaır.

Eens

Oneens

Eens

Oneens

Eens

Oneens

Eens

Oneens

12 Als u medicus was, zou u de turbuliente werksfeer van de psychiater prefereren bover de strak georganiseerde werkomgeving van de chirurg.

13 Onduidelijke en impressionistische afbeeldingen zeggen u niet zoveel.

14 Als w onderzoeker was, zou het u storen dat uw werk nooit af zon zijn omdat er altijd weer nieuwe resultater konen.

15 Als u van te voren weet hoeveel vragen er gesteld worden op een examen, voelt u zich lang niet zo zenuwachtig.

16 Het leukste moment wan her maken van een legpuzzel is het aunbrengen wan het laatste stukje.

Eens

Oneerns

Eens

Oneens

Eens

Oneerns

Eens

Oneans

Eens

Oneens

Eens

Oneens

17 Soms vindt $u$ bet lleuk om regels te overtreden en dingen te doen die u niet

Eens

Oneens geache wordt te doen.

$18 U$ windt er weinig aan on an een probleem te werken zonder in staat te zijn met een duidelijke en ondubbelzinnige oplossing te komen.

Eens

Oneens

$19 U$ vindt het wel a ardig om met nieuwe ideeën te spelen, ook al blijkt later dat ze geen enkel nut hebben.

Eens

Oneens

20 Een goed schriftelijk rapport is bovenal evenwichtig.

Eens

Oneens 


\section{Bijlage 6: Personeelszakenproces, de casusstelling}

\section{$\begin{array}{ll}\text { Omgeving van de casus } & 217\end{array}$}

$\begin{array}{ll}\text { Processen, procedures en activiteiten } & 218\end{array}$

Verkrijging. . . . . . . . . . . . . . . . 218

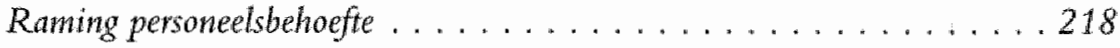

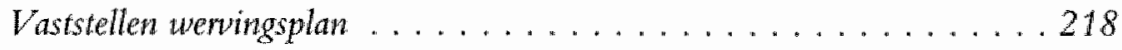

Vaststellen pacatures..................... . 218

Werving en selectie . . . . . . . . . . . . . . . 218

Aanmaken arbeidsovereenkomst. . . . . . . . . . . . . 219

Verwerken arbeidsovereenkomsten. ..............219

Controleren verwerken arbeidsovereenkomsten . . . . . . . . . 219

Exploitatie . . . . . . . . . . . . . . . . . 220

Muteren stamgegevens. . . . . . . . . . . . . . . 220

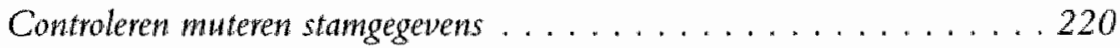

Opleiden/trainen. ...................... . 220

Beoordelen functioneren . . . . . . . . . . . . . . . . 220

Bevorderen..........................221

Periodick muteren loon . . . . . . . . . . . . . . 221

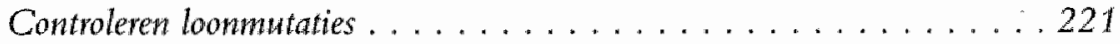

Registreren ziekte/verlof . . . . . . . . . . . . . . 222

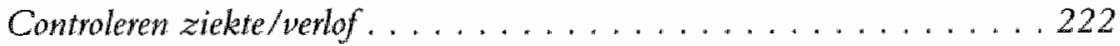

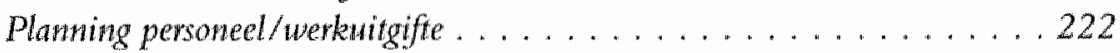

Vastleggen aanwezigheid personeel . . . . . . . . . . . . 222

Vaststellen prestatie werknemers. . . . . . . . . . . . . 223

Controleren aanwezigheid . . . . . . . . . . . . . . 223

Overplaatsen personeel . . . . . . . . . . . . . . . 223

Controleren overplaatsen personeel . . . . . . . . . . . 224

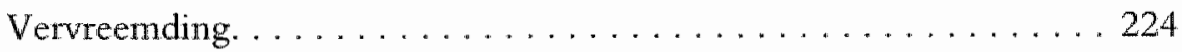

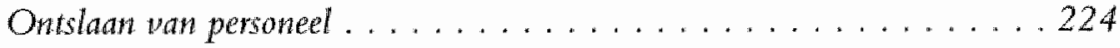

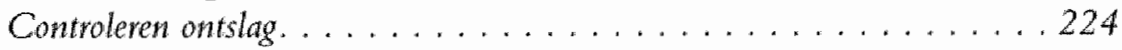

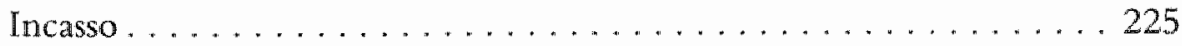

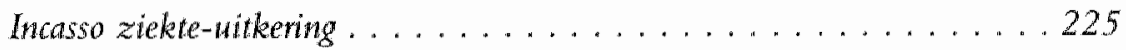

Controleren incasso ziekte-uitkering . . . . . . . . . . . 225 
Excasso . . . . . . . . . . . . . . . . . . . . . 225

Vaststellen loongegevens. . . . . . . . . . . . . . . . 225

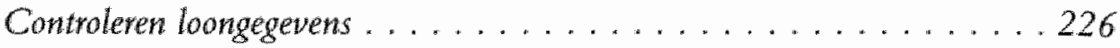

Betalen verschuldigd loon. . . . . . . . . . . . . 226

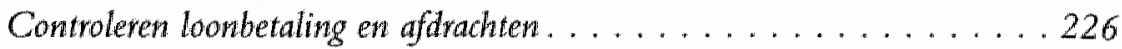

Journaliseren loonbetalingen . . . . . . . . . . . . 227

Controleren joumaliseren lonew . . . . . . . . . . . . . 227 


\section{Omgeving van de casus}

Het onderstaande Personeelszakenproces $(\mathrm{PZ})$ wordt toegepast binnen een productie onderneming met een omvang van 2000 werknemers waarvoor een $\mathrm{CAO}$ is afgesloten. In de CAO is afgesproken dat bij ziekte aanvulling tot $100 \%$ plaatsvindt. Het bedrijf kan worden getypeerd als een financieel gezonde onderneming met expansiemogelijkheden in een rustig groeiende markt.

De onderneming kent een aparte afdeling personeelszaken met daarbinnen twee onderafdelingen te weten personeelsbureau en personeelsadministratie.

Binnen de afdeling personeelszaken wordt gebruik gemaakt van de volgende geautomatiseerde informatiesystemen:

- het personeelsregistratiesysteem (PRS) met individuele gegevens van personeelsleden;

- het personeelsregistratiesysteem-controle (PRS-C) met standenregisters;

- het salarisregistratiesysteem (SRS) met bruto en netto salarisgegevens ten behoeve van het daadwerkelijk uitvoeren van betalingen;

- het financieel registratiesysteem (FRS) met de financiële administratie.

Alle systemen zijn ontwikkeld door een extern softwarehouse met een ISO-9000certificaat en zijn een groot aantal keren geïmplementeerd (grote "installed base"). Voor de onderneming zijn geen specifieke aanpassingen gemaakt en het onderhoud is uitbesteed aan het softwarehouse.

De informatiesystemen draien op een mainframe van de onderneming waarbij gebruik wordt gemaakt van een database die door een goede inrichting van de logische toegangsbeveiliging alleen beschikbaar is voor de daartoe geautoriseerde functionarissen. Mutaties worden real-time verwerkt.

Maandelijks worden interne controles uitgevoerd onder eindverantwoordelijklheid van de financiële administratie. Er wordt zowel een formele als een materiële controle uitgevoerd. Hierbij wordt gebruik gemaakt van door de directie vastgestelde taak- en functieomschrijvingen met daarin opgenomen bevoegdheden en daarmee corresponderende handtekening- en parafenlijsten. Waar mogelijk wordt de controle ondersteund door vergelijking van het PRS met het PRS-C. Standaard is dat na iedere controle een rapportage plaatsvindt ten behoeve van de directie, welke daarna beslissingen neemt ten aanzien van te nemen maatregelen.

De onderneming heeft al haar procedures gedocumenteerd waarbij als normatieve indeling per procedure is aangehouden: verkrijging, exploitatie, vervreemding, incasso, excasso. 
Algemeen geldt binnen de onderneming dat alle extern ontvangen en intern vervaardigde documenten, tenzij anders vermeld, gearchiveerd worden conform de daaraan te stellen eisen.

\section{Processen, procedures en activiteiten}

\section{Verkrijging}

Raming personeelsbehoefte

Alvorens personeel kan worden aangenomen dient eerst een raming te worden gemaakt van de personeelsbehoefte. Hiertoe wordt jaarlijks aan de afdelingshoofden gevraagd om per functiecategorie een voorstel te doen inzake invulling van het formatieplan. Op basis van deze voorstellen stelt de directie het definitieve formatieplan voor de gehele onderneming vast. Door de directie wordt voorts het op dit formatieplan gebaseerde personeelsbudget vastgesteld. De administratie voert het personeelsbudget in, in het PRS. Op het personeelsbureau wordt aan de hand van de gegevens uit het PRS de huidige personeelscapaciteit vastgesteld. Tevens ontvangt het personeelsbureau van de afdelingshoofden een rapportage over het te verwachten personeelsverloop. Op basis van het personeelsbudget, de huidige capaciteit, het te verwachten personeelsverloop en het formatieplan, stelt het personeelsbureau de 'raming personeelsbehoefte' per afdeling en functie vast, welk document wordt gebruikt bij het vaststellen van het wervingsplan.

\section{Vaststellen wervingsplam}

Op basis van de 'raming personeelsbehoefte', het personeelsbudget en het door de directie opgestelde langetermijn plan stelt het personeelsbureau een wervingsplan op. Dit wervingsplan wordt gebruikt als sturingsinstrument bij het vaststellen van de vacatures.

\section{Waststellen vacatures}

Wekelijks stelt het personeelsbureau de vacatures vast. Dit gebeurt aan de hand van het wervingsplan en het PRS. De vacatures worden uitgedraaid en gebruikt bij de werving en selectie van personeel.

\section{Werving en selectie}

Op basis van de opengestelde vacatures, wervingsplan en mutatieverslag overplatsingen werft het personeelsbureau kandidaten voor de beschikbare functies. De selectie wordt mede uitgevoerd aan de hand van de van de sollicitant ontvangen sollicitatiebrief. Van de gehele sollicitatie wordt een sollicitatiebeoordeling opgesteld. Op basis van deze beoordeling en het van de keuringsarts ontvangen keuringsrapport 
beslist het personeelsbureau over aanname of afwijzing. Als de sollicitant wordt aangenomen, stelt het personeelsbureau in tweevoud een schriftelijke voordracht op. Een exemplaar is voor de sollicitant; het andere exemplaar wordt later gebruikt bij het aanmaken van de arbeidsovereenkomst. Als de kandidaat wordt afgewezen, stelt het personeelsbureau een afwijzingsbrief op die naar de sollicitant wordt opgestuurd.

\section{Aanmaken arbeidsovereenkomst}

Op basis van de voordracht, persoonsgegevens en conform richtlijnen van de directie, maakt de personeelsadministratie de arbeidsovereenkomst aan. Hierbij wordt uitgegaan van de $\mathrm{CAO}$-voorwaarden welke in de directierichtlijn zijn verwerkt. De arbeidsovereenkomst wordt in tweevoud opgemaakt. De directie controleert de arbeidsovereenkomst. Bij goedkeuring ondertekent de directie de arbeidsovereenkomst. De personeelsadministratie stuurt beide exemplaren naar de sollicitant ter ondertekening. Bij afkeuring wordt de arbeidsovereenkomst met opmerkingen van de directie teruggestuurd naar de personeelsadministratie. De arbeidsovereenkomst wordt gecorrigeerd en dezelfde goedkeuringsprocedure wordt opnieuw doorlopen.

\section{Verwerken arbeidsovereenkomsten}

Nadat de arbeidsovereenkomst en de loonbelastingverklaring ondertekend van de sollicitant retour zijn ontvangen muteert het personeelsbureau de standenregisters in het PRS-C. Hierna verwerkt de personeelsadministratie de individuele gegevens in het PRS en draait hiervan een mutatieverslag uit. Tenslotte confronteert het personeelsbureau het PRS met het PRS-C waarna, ook indien geen verschillen worden geconstateerd, een verschillenlijst wordt gedraaid.

\section{Controleven verwerken arbeidsovereenkornsten}

Bij de controle wordt gebruik gemaakt van mutatieverslagen, de arbeidsovereenkomsten, loonbelastingverklaringen, directierichtlijnen, een speciaal voor dat doel aitgegeven en door de directie goedgekeurde checklist aangande fiscaal/juridische aspecten en het PRS en het PRS-C.

Bij de formele controle wordt vastgesteld dat:

- de arbeidsovereenkomsten opgesteld zijn conform de richtlijnen en voorschriften;

- aan alle fiscaal/juridische aspecten aandacht is gegeven.

Bij de materiële controle wordt vastgesteld dat:

- alle arbeidsovereenkomsten tijdig verwerkt zijn, waarbij gekeken wordt naar de doorlopende nummervolgorde en de datum waarop de arbeidsovereenkomst is ondertekend;

- alle aannamegegevens juist zijn ingevoerd in het PRS;

- de tellingen uit het PRS aansluiten op de standenregisters uit het PRS-C. 


\section{Exploitatie}

\section{Muteren stamgegevens}

Er zijn twee mogelijke aanleidingen voor het wijzigen van de stamgegevens van de personeelsleden. De eerste is dat een personeelslid een wijziging varn zijn gegevens doorgeeft. De tweede heeft betrekking op de verschillenlijsten die in de diverse gegevensverwerkende processen ontstaan. Deze lijsten worden namelijk in dit proces afgewerkt. Doet zich een wan deze mogelijkheden voor, dan verwerkt het personeelsbureau de gegevens in de standenregisters in het PRS-C. De personeelsadministratie voert de mutatie van de individuele gegevens door in het PRS en draait hiervan een mutatieverslag uit. Tenslotte confronteert het personeelsbureau het PRS met het PRS-C waarna, ook indien geen verschillen worden geconstateerd, een verschillenlijst wordt gedraaid.

\section{Controleren mutteren stamgegevens}

Bij de controle wordt gebruik gemaakt van mutatieverslagen en het PRS en het PRS-C.

$\mathrm{Bij}$ de formele controle wordt vastgesteld dat:

- de verschillenlijsten zijn opgesteld en afgewerkt conform de richtlijnen;

- de gegevens gemuteerd zijn binnen de richtlijnen en voorschriften.

Bij de materiële controle wordt vastgesteld dat:

- alle mutaties tijdig verwerkt zijn;

- alle mutaties juist zijn ingevoerd in het PRS;

- de tellingen uit het PRS aansluiten op de standenregisters uit het PRS-C.

\section{Opleiden/trainen}

Op basis van het loopbaanplan (ontstaan tijdens het beoordelen van het personeelslid), een opleidingsverzoek van het personeelslid dan wel afdelingshoofd en het opleidingsaanbod, schrijft het personeelsbureau de personeelsleden in voor een cursus. Hiertoe stuurt het personeelsbureau een blanco inschrijvingsformulier naar het personeelslid en het retour ontvangen (ingevulde) formulier naar het afdelingshoofd en het opleidingsinstituut. De personeelsadministratie verwerkt de gegevens in het PRS.

\section{Beoordelen functioneren}

Het personeelsbureau draait uit het PRS een prestatielijst per personeelslid.

Op basis van deze prestatielijst, het functioneringsrapport opgesteld door het afdelingshoofd, de reactie hierop van het personeelslid alsmede de door het personeelslid ingevulde functioneringsvragenlijst en de door de directie vastgestelde beoordelingscriteria voert het personeelsbureau jaarlijks een functionerings- en beoordelingsgesprek met de personeelsleden. Resultaat van het gevoerde gesprek is een func- 
tiebeoordeling en een loopbaanplan. De gegevens uit deze twee formulieren worden op de personeelsadministratie ingevoerd in het PRS. Het loopbaanplan wordt vervolgens gebruikt bij het opleiden/trainen wan het personeel; de functiebeoordeling wordt naderhand gebruikt bij het bevorderen van personeelsleden.

\section{Bevorderen}

Het bevorderen van medewerkers en het geven van individuele salarisverhogingen gebeurt op aanvraag van een afdelingshoofd of het desbetreffende personeelslid zelf. Vervolgens stelt het personeelsbureau aan de hand van de functiebeoordeling, het personeelsbudget, de directierichtlijnen en het loopbaanplan een voorstel voor de bevordering en de loonmutatie op. Het voorstel wordt voor autorisatie naar de directie doorgestuurd. Slechts bij goedkeuring werkt het personeelsbureau de standenregisters in het PRS-C bij. Hierna verwerkt de personeelsadministratie de individuele gegevens in het PRS en stelt het personeelslid op de hoogte van de beslissing. Tevens wordt er een mutatieverslag uitgedraaid. Tenslotte confronteert het personeelsbureau het PRS met het PRS-C waarna, ook indien geen verschillen worden geconstateerd, een verschillenlijst wordt gedraaid.

\section{Periodiek muteren loon}

De periodieke salarismutaties zijn het resultaat van het $\mathrm{CAO}$-overleg. De uitkomst van dit overleg is de basis voor een door het personeelsbureau uitgevoerde simulatieberekening waarbij de gevolgen van de invoering van de nieuwe $\mathrm{CAO}$ zichtbaar worden gemaakt. Op basis van deze simulatie wordt de $\mathrm{CAO}$ door de directie geautoriseerd. Als de autorisatie niet wordt gegeven wordt de mutatie niet doorgevoerd. Bij goedkeuring wordt het personeelsbureau daarvan in kennis gesteld. Het personeelsbureau verwerkt de autorisatie in het PRS-C. De personeelsadministratie verwerkt de CAO-gegevens op individuele basis in het PRS en draait hiervan een mutatieverslag uit. Tevens stelt zij de personeelsleden ervan in kennis. Tenslotte confronteert het personeelsbureau het PRS met het PRS-C waarna, ook indien geen verschillen worden geconstateerd, een verschillenlijst wordt gedraaid.

\section{Controleren loonmutaties}

Bij de controle wordt gebruik gemaakt van de mutatieverslagen, de aanvragen loonmutaties en promoties, de CAO-gegevens, functiebeoordelingen, loonmutaties, richtijnen van de directie en budgetten en het PRS en het PRS-C.

Bij de formele controle wordt vastgesteld dat:

- de juiste procedure is gevolgd bij de beoordeling, bevordering en toekenning van individuele loonmutatie;

- de juiste procedure is gevolgd bij het afsluiten van de CAO;

- de gegevens gemuteerd zijn binnen de richtlijnen en voorschriften. 
Bij de materiële controle wordt vastgesteld dat:

- alle mutaties tijdig verwerkt zijn;

- alle mutatiegegevens juist zijn ingevoerd in het PRS;

- de controletotalen op de mutatieverslagen, zowel in aantal als waarde, aansluiten bij de gegevens volgens de $\mathrm{CAO}$ en de door de directie goedgekeurde loonmutaties;

- de tellingen uit het PRS aansluiten op de standenregisters uit het PRS-C.

\section{Registreven ziekte/verlof}

Dagelijks ontvangt de personeelsadministratie van de afdelingshoofden een opgave van de medewerkers die verlof hebben opgenomen en van de personeelsleden de ziekmeldingen. Deze gegevens worden conform directierichtlijnen in het PRS verwerkt. Na verwerking worden totaaloverzichten uitgedraaid en ten behoeve van de incasso van de ziekte-uitkering naar de ARBO-verzekering gezonden. Tevens wordt een mutatieverslag uitgedraaid.

\section{Controleren ziekte/terlof}

Bij de controle wordt gebruik gemaakt van de mutatieverslagen, de ziekteoverzichten, de verlof- en ziektemeldingen, de richtlijnen van de directie en het PRS.

Bij de formele controle wordt vastgesteld dat:

- de juiste procedure is gevolgd bij ziektemelding en toekennen van verlof;

- de gegevens gemuteerd zijn binnen de richtlijnen en voorschriften.

$\mathrm{Bij}$ de materiële controle wordt vastgesteld dat:

- alle mutaties tijdig verwerkt zijn;

- alle mutatiegegevens juist zijn ingevoerd in het PRS;

- de controletotalen op de mutatieverslagen, zowel in aantal als waarde, aansluiten bij de gegevens volgens de ziektemeldingen, verloftoekenningen en ziekte-uitkering.

\section{Planning personeel/werkuitgifte}

Wekelijks maakt het bedrijfsbureau met behulp van het PRS een werkopdracht en werkroosters aan. Deze worden zowel aan de personeelsleden als aan de afdelingshoofden verstrekt.

\section{Vastleggen anmwezigheid personeel}

De personeelsleden registreren dagelijks, onder oogtoezicht van de portier, hun aanwezigheid in het PRS door "klokken" bij binnenkomst en verlaten van het gebouw. De aanwezigheid op de afdelingen wordt vastgelegd door de afdelingshoofden die de tijdverantwoordingen voor verwerking in het PRS aanbieden aan de personeelsadministratie, alwaar verwerking plaatsvindt. Hierbij maakt de personeelsadministratie 
gebruik van het portiersrapport. Na de verwerking draait de personeelsadministratie een mutatieverslag uit.

\section{Vaststellen prestatie werknemers}

Het bedrijfsbureau verwerkt in het PRS de individuele prestaties van de personeelsleden. Dit vindt plaats op basis van de op de werkopdrachten en de van de afdelingshoofden ontvangen productierapporten. Door de personeelsadministratie wordt een tweetal overzichten vervaardigd te weten: een job-shop-time overzicht en een shopcontract-time overzicht. Hierbij wordt gebruikgemaakt van het PRS en het PRS-C. Op basis van de aangeleverde overzichten neemt het personeelsbureau follow-upmaatregelen welke schriftelijk worden vastgelegd.

\section{Controleren aanwezigheid}

Bij de controle wordt gebruik gemaakt van de mutatieverslagen, de tijdverantwoordingen, de overzichten job-shop-time en shop-contract-time, portiersrapporten, arbeidsovereenkomsten, richtlijnen van de directie, documenten waarop de genomen follow-up-maatregelen vermeld staan en het PRS en het PRS-C.

Bij de formele controle wordt vastgesteld dat:

- de juiste procedure is gevolgd bij het vaststellen van de aanwezigheid;

- de gegevens gemuteerd zijn binnen de richtlijnen.

Bij de materiële controle wordt vastgesteld dat:

- alle aanwezigheidsgegevens tijdig verwerkt zijn;

- alle planningen zijn verwerkt aan de hand van de doorlopende weeknummers;

- alle aanwezigheidsgegevens juist zijn ingevoerd in het PRS;

- de aanwezigheid overeenkomstig is met het arbeidscontract;

- de controletotalen op de mutatieverslagen, zowel in aantal als waarde, ansluiten bij de gegevens volgens week-werkplanningen;

- de reacties op door het PRS gesignaleerde afwijkingen goed zijn uitgevoerd, overeenkomstig de richtlijnen en voorschriften;

- de tellingen uit het PRS aansluiten op de standenregisters uit het PRS-C.

\section{Overplaatsen personeel}

Afdelingshoofden en personeelsleden kunnen bij het personeelsbureau een verzoek indienen tot overplaatsing. Bij het afdelingshoofd gaat het om een verzoek aangaande een op de desbetreffende afdeling werkzame persoon terwijl het bij het personeelslid om een verzoek voor het personeelslid zelf gaat. Het personeelsbureau beoordeelt dit verzoek. Zowel bij goed als afkeuring verwerkt de personeelsadministratie de aanvraag en de beslissing in het PRS waarna een mutatieverslag wordt uitgedraaid dat gebruikt wordt bij het werven en selecteren ten behoeve van open- 
gestelde vacatures. Van de beslissing wordt zowel het afdelingshoofd als de medewerker op de hoogte gesteld.

\section{Controleren overplaatsen persomee!}

Bij de controle wordt gebraik gemaakt van de verzoeken en besluiten tot overplatsing, mutatieverslagen, directierichtlijnen en het PRS.

Bij de formele controle wordt vastgesteld dat:

- de verzoeken opgesteld zijn conform de richtlijnen aanvragen overplaatsing;

- de juiste procedure is gevolgd bij het overplaatsingsbesiluit.

Bij de materiele controle wordt vastgesteld dat:

- alle besluiten tot overplaatsing tijdig verwerkt zijn;

- alle besluiten tot overplaatsing juist zijn ingevoerd in het PRS.

\section{Vervreemding}

\section{Ontslan van personeel}

Door een afdelingshoofd of een personeelslid kan een schriftellijk verzoek tot ontslag worden ingediend bij het personeelsbureau. Een dergelijk verzoek dient eveneens te worden ingediend bij het bereiken van de pensioengerechtigde leeftijd, VUT-leeftijd of afkeuring in het kader van de WAO. Het personeelsbureau neemt mede op basis van in- en externe richtlijnen een besluit. Het personeelsbureau werkt vervolgens de standenregisters in het PRS-C bij. Hiema verwerkt de personeelsadministratie de individuele gegevens in het PRS en stelt het afdelingshoofd en het personeelslid op de hoogte. Tenslotte confronteert het personeelsbureau het PRS met het PRS-C waarna, ook indien geen verschillen worden geconstateerd, een verschillenlijst wordt gedraaid.

\section{Controleren ontslag}

Bij de controle wordt gebruik gemaakt van de mutatieverslagen, de ontslagaanvragen en de ontslagbesluiten, richtlijnen van de directie en het PRS en het PRS-C.

Bij de formele controle wordt vastgesteld dat:

- de juiste, zorgvuldige, procedure is gevolgd bij de ontslagaanvraag;

- de gegevens gemuteerd zijn binnen de richtlijnen en voorschriften.

Bij de materielle controle wordt vastgesteld dat:

- alle mutaties tijdig verwerkt zijn;

- alle mutatiegegevens juist zijn ingevoerd in het PRS;

- de controletotalen op de mutatieverslagen, zowel in antal als waarde, aanshiten bij de gegevens volgens de ontslagverleningen;

- de tellingen uit het PRS aansluiten op de standenregisters uit het PRS-C. 


\section{Incasso}

\section{Incasso ziekte-tuitkering}

Maandelijks controleert de personeelsadministratie of de van de ARBO-verzekering ontvangen declaratie ten aanzien van de ziekte-uitkering, overeenstemt met de kopie van het ziekteoverzicht zoals dat is aangemaakt tijdens het registreren van ziekte en verlof en de vergoedingsregeling van de $A R B O$-verzekering. Indien afwijkingen worden geconstateerd wordt de declaratie geretourneerd aan de ARBO-verzekering. Indien de declaratie wordt goedgekeurd voert de financiële administratie de gegevens in het debiteurenbestand van het FRS. Op basis van het van de bank ontvangen dagafschrift boekt de financiële administratie het FRS af.

\section{Controleven incasso ziekte-witkering}

Bij de controle wordt gebruik gemaakt van de bankafschriften, de ziekteoverzichten en de declaratie, richtijinen van de directie, de vergoedingsregeling van de ARBOverzekering bij ziekte en het FRS.

Bij de formele controle wordt vastgesteld dat:

- de juiste procedure is gevolgd bij de controle en incasso van de ontvangen declaratie;

- de gegevens gemuteerd zijn bimnen de richtlijnen en voorschriften.

Bij de materiële controle wordit vastgesteld dat:

- alle mutaties tijdig verwerkt zijn;

- alle mutatiegegevens juist zijn ingevoerd in het FRS;

- de controletotalen op de mutatieverslagen, zowel in aantal als waarde, aansluiten bij de gegevens volgens de declaratie.

\section{Excasso}

\section{Vaststellen loongegevens}

Door de personeelsadministratie wordt het PRS en het PRS-C voor de contracturen in totalen op elkaar aangesloten. Verschillenlijsten worden aangemaakt ongeacht of verschillen zijn geconstateerd. Indien geen verschillen zijn geconstateerd ontleent de personeelsadministratie brutoloongegevens, op basis van contract- en overuren, aan het PRS en schrijft dit weg in het SRS. Door de personeelsadministratie wordt vervolgens de bruto/netto berekeningsmodule opgestart die de nettoloongegevens berekent en wegschrijft in het SRS. 


\section{Controleren loongegevens}

Bij de controlle wordt gebruik gemaakt van controlebevindingen, het PRS, het PRS-C en het SRS.

Bij de formele controle wordt vastgesteld dat:

- alle controlebevindingen zijn afgehandeld conform de daarvoor door de directie gegeven richtlijnen.

Indien dit niet is gedan worden de bevindingen voorgelegd an de directie en wordt verdere afhandeling stopgezet.

Bij de materiele controle wordt vastgesteld dat:

- de juiste versie van de bestanden is gebruikt;

- de tellingen uit het PRS en het SRS aansluiten op de standenregisters wit het PRSC.

Naar aanleiding van de uitkomsten van de controle wordt het SRS vrijgegeven voor betaling. Dit vrijgeven vindt plaats door het in een zodanige status brengen van het SRS dat deze niet meer langs de normale weg gemuteerd kan worden.

\section{Betalen verschuldigd loon}

De personeelsadministratie vervaardigt met behulp van het PRS en het vrijgegeven SRS loonoverzichten per werknemer en per periode, de periodieke opgave belastingen en sociale wetten alsmede de betalingsopdracht lonen. De afdeling Financiën autoriseert de loonbetaling en de afdrachten en werkt het SRS en het FRS bij. Hierbij maakt zij gebruik van het PRS en het vrijgegeven SRS. Na goedkeuring zorgt zij voor de verzending van de opdracht naar de bank. Op basis van het ontvangen dagafschrift van de bank werkt de financiële administratie het vrijgegeven SRS en het FRS bij.

\section{Controleven loonbetaling en afdrachten}

Bij de controle wordt gebruikgemakt van de betalingsopdracht lonen, de bankafschriften en het PRS, SRS en FRS. Er wordt wastgesteld dat:

- de juiste procedure is gevolgd bij het aanmaken van de betaling;

- de betaling tijdig heeft plaatsgevonden;

- de juiste bestanden met betaalgegevens zijn gebruikt;

- het totaalbedrag van de betaling overeenstemt met de te betalen loonbedragen, afdrachten en te betalen loonbelasting volgens het afgifteformulier;

- de reacties op door het systeem van financiën gesignaleerde afwijkingen goed zijn uitgevoerd, overeenkomstig de richtlijnen en voorschriften;

- de doorverwerkingen in het FRS zijn uitgevoerd. 


\section{Joumaliseren loonbetalingen}

Door de personeelsadministratie worden maandelijks na de definitieve betaling de lonen verder doorgeboekt in het grootboek door het opstarten van de loonverdeelstaat-routine. Gebruik wordt gemaakt van het SRS, FRS en het PRS. Als resultaat wordt een loonverdeelstaat aangemaakt.

\section{Controleven journaliseren lonen}

Bij de controle wordt gebruik gemaakt van de loonverdeelstaat en het PRS, FRS en SRS. Er wordt vastgesteld dat:

- de juiste procedure is gevolgd bij het journaliseren;

- de journalisering tijdig heeft plaatsgevonden;

- de totaalbedragen van de journalisering overeenstemmen met de te betalen loonbedragen, afdrachten en te betalen loonbelasting volgen het afgifteformulier.

\section{Uw oordeel}

Uw oordeel over de administratieve organisatie zoals beschreven in bovenstaande case:
Uitstekend
Zeer goed
Goed
Voldoende

Onvoldoende

Slecht

Zeer slecht

Hoe vaak schatu dat deze case in uw praktijk voor komt:

\begin{tabular}{lll}
\hline $0 \%$ & $10 \%$ & $20 \%$ \\
$30 \%$ & $40 \%$ & $50 \%$ \\
$60 \%$ & $70 \%$ & $80 \%$ \\
$90 \%$ & $100 \%$ &
\end{tabular}




\section{Bijlage 7: Deelprocessen, procedures, activiteiten en beheersing}

\section{Deelproces: \\ Verkrijging \\ Verkriger \\ ramings \\ personeelsbehoefte}

\section{Activiteit}

vaststellen formatieplan

vaststellen personicelsbuidget

invoeren personeelsbudget

vaststellen huidige capaciteit

inschatten verwachte verloop

vaststellen personeclisbehoefte

vaststellen wervingsplan

vaststellen vacatures

werving en selectie

aanmaken

arbeidsovereenkomst

verwerken

arbeidsowereenkonst

controleren verwerken arbeidsovereenkomsten.

Exploitatite muteren stamgegevens

controleren nuteren stangegevens

opleiden / trainen opstellen wervingsplan

vaststellen vacatures

werwing personeelsleden

afwijzen

voordragen

aanmaken arbeidsovereenkomst

beoordeleru arbeidsovereenkomst

werwerken afwijzen arbeidsovereenkonst

ondertekenen arbeidsovereenkornst

versturen arbeidsovereenkomst

verwerken arbeidsovereenkomst PRS-C

verwerken arbeidsovereenkomsten PRS

aanmaken werschillenlijst

arbeidsovereenkomst.

controleren arbeidsovereenkomsten.

controleren verwerken

arbeidsovereenkomsten

verwerken gegevens PRS-C

muteren stamgegevens PRS

aanmaken verschillenlijst stamgegevens

controleren muteren persoonsgegevens

controleren verwerken mutatie

stitngegevers

inschrijven opleidingen

verwerken inschrijving opleiding $\mathrm{v}$

E

Beheersing

$\mathrm{V}$

F

F

$\mathrm{v}$

$\mathrm{V}$

V

V

$\mathrm{V}$

$\mathrm{V}$

$\mathrm{V}$

V

V

V

V

V

v

I

V

I

P

P

I

P

P

E 


\section{Deelproces

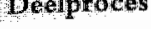

\section{Procedure}

beoordelen funcrioneren

bevorderen

periodiek muteren loon

controleren loon mutaties

registreren ziekte / verlof

controleren ziekte /

verlof

planning personeel/

werkuitgifte

vastleggen aanwezigheid

personeel

vaststellen prestatie

werknemers

controleren aanwerigheid

overplaatsen personicel

controle overplatsen

personeel

Vervremding ontslaan van personeed

\section{Activiteit}

uitdraiaen prestatie

functioneringsgesprek woeren

invoeren functionering

vaststellen loonmutatie

autoriseren loonnutittie

verwerken loonmutatie PRS-C

invoeren loonmutatie PRS

aanmaken verschillenlijst loonmutatie

simulatie

autoriseren $\mathrm{CAO}$

verwerken autorisatie $\mathrm{CAO}$ in PRS-C

verwerken periodieke loonmutatie PRS

aanmaken verschillenlijst loonnutatie

controleren mutaties lonen

controleren verwerken mutaties

registreren ziekte / verlof

controleren ziekte / verlof

controleren registratie ziekte / verlof

indelen personeel

registratie anwezigheid

invoeren productie

anmmaken controlelijsten

nemen van follow-up-matregelen

controleren anwezigheid

controleren registratic anwezigheid

verzoek owerpllatsen beoordelen

verwerken besluit owerplatsing

controleren overplaatsing

controleren verwerking overplaatsing

verzoek ontslag beoordelen

verwerken besluit ontslag in PRS-C

verwerken besluit ontslag in PRS

aanmaken verschillemlijst ontslag

\section{Boheersing}

E

E

E

V

$\mathrm{v}$

I

V

1

V

V

1

v

II

p

P

E

P

P

V

E

E

E

E

P

$\mathrm{P}^{3}$

v

W

P

P 


\begin{tabular}{|c|c|c|c|}
\hline \multirow[t]{3}{*}{ Deelproces } & Procedure & Activiteit & Beheersing \\
\hline & \multirow[t]{2}{*}{ controleren ontslidg } & controleren ontslag personed & $\mathrm{P}$ \\
\hline & & controleren werwerken ontslags & $\mathrm{p}$ \\
\hline \multirow[t]{5}{*}{ Incassoo } & \multirow[t]{3}{*}{ inciasso zickte-tutkering } & controleren zieken-declaraties & $\mathbb{E}$ \\
\hline & & werwerken declaratie ziektedagen & $E$ \\
\hline & & verwerken ontwangst declaratic & E \\
\hline & controleren incasso & controleren zieken-declaraties & $\mathbb{P}$ \\
\hline & ziekte-uitkering & controleren registratie ziekengelden & $\mathrm{p}$ \\
\hline \multirow[t]{14}{*}{ Excasso } & \multirow[t]{4}{*}{ vastitellen loongegevens } & matchen PRS en PRS-C & I \\
\hline & & aanmaken verschillenlijst loongegevens & 1 \\
\hline & & berekenen bruto loongrgevens & $v$ \\
\hline & & berekenen netto loongegevers & $v$ \\
\hline & \multirow[t]{4}{*}{ controleren loongegevens } & $\begin{array}{l}\text { controleren afluandeling } \\
\text { controlebevindingen }\end{array}$ & P \\
\hline & & opstellen controlebevindingen & $\mathrm{p}$ \\
\hline & & controle loongegevens & $\mathrm{P}$ \\
\hline & & vrijgeven voor betaling & $\mathrm{P}$ \\
\hline & \multirow[t]{3}{*}{ betalen verselxuldigd loon } & anmaken owerzichten & $\mathrm{V}$ \\
\hline & & autoriseren Loonbetaling / afdrachten & $\mathrm{V}$ \\
\hline & & verwerket loonbetaling & $\mathrm{V}$ \\
\hline & controleren betallingen & controlerem loonbetalingen en afdrachten & $\mathrm{P}$ \\
\hline & $\begin{array}{l}\text { journaliseren } \\
\text { Joonbetalingen }\end{array}$ & verwerken lonen in grootboek & V \\
\hline & $\begin{array}{l}\text { controleren journaliseren? } \\
\text { lonen }\end{array}$ & controleren journaliseren lonen & $\mathrm{P}$ \\
\hline
\end{tabular}

Legenda beheessingsirstrumentarium per activiteit

$V:$ "verplictat" opgenomen in alle cases:

P: opgenomen in alle cases waarin maatregelen wan 'Procesbeheersing" zijn verwerkt,

fl: opgenomen in alle casses warin maatregelen wan 'Financiele beheersing' zijo verwerkt;

$O$ : maatregelen van 'Organisatorische beheersing' zijn verwerkt in de ongeving van alle cases waardoor geen verwijzing naar activiteiten plats heeft gevonden;

1: opgenomen in alle cases watin maatregelen van "Informatie beheersing" zijn wenwerkt;

E: opgenomen in alle cases warin maatregelen van 'Prestatiebeheersing' zijn werwerkt. 


\section{Bijlage 8: Overzicht casusstellingen met aanwezige beheersingsmaatregelen}

Concretisering van NIET opge- Omschrijving van WEL opgenomen beheersingsmantre nomen beheersingsmaatregelen gelen

zoals besclireven in de casusstelling

Proces Financieel Organisatie Informatie Prestatie (P)

(P)

(F)

(o)

())

(E)

(basis-model)

$\mathrm{p}$

F

controle

$\mathrm{F}$

PRS-C.

F

$\mathrm{O}$

E

$2 \mathrm{PK}^{2}$

P

F"

0

E

budget

P

o

E

P

o

0

\section{E}

P F

E

functiescheiding

F

E

controle, ZPK

F

o

controlle, budget

o I

controle, functiescheiding

o

E

PRS-C, ZPK

F

E

PRS-C, budget

F

0

$\mathrm{P}$

O

$\mathbb{E}$

PRS-C, functiescheiding

P

$\mathrm{F}$

E

14. ZPK, budget

P

$p$

F

o

ZPK, funcriescheiding

P

budget, funcriescheiding

controlle, PRS $S-C, Z P K$

controle, PRS-C, budget

controle, PRS-C, functicscheiding.

controle, ZPK, budget

controle, ZPK, functiescheiding

controle, budget, functiescheiding

E

23 PRS-C, ZPK, budget

P

o

PRS-C, ZPK. functiescheiding

$\mathrm{P}$

$\mathrm{F}$

PRS $\mathrm{C}$, budget, functiescheiding

P

E

$Z \mathrm{PK}$, butget, functiescheiding

P

controle, PRS-C, ZPK, budget

controle, PRS-C, ZPK,

functiescheiding

$\mathbb{E}$ 
Coneretisering van NUET opge- Onschrijving yan WEL opgenomem beheersingsnantrenomen beheet thingmiatregellen gelen

zoals beschreven in ale castusstelling

Proces Financied Organisatie Informatie Prestatie

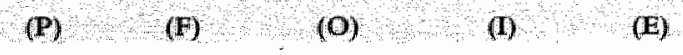

29 controle, $\operatorname{MRS}-\mathrm{C}$, budger.

finctiescherding

30 controle, ZPK, budget, functiescheiding

31 PRS $-\mathrm{C}, \mathrm{ZPK}$, budget; P functiescheiding

32 controle, PRS-C, ZPK, budget huctieschaiding (alles)

1. 'Zonder PRS-C' impliceent dat geen gebruik gemaakt wordt van mogelijheden als standenregisters.

2. 'Zonder ZPK' implicest dat geen tegistratie platsvindt van ziekteverzum, anbeidsprestarie en kennisontwikkeling. 


\section{Bijlage 9: Myers-Briggs type indicator, een leeswijzer}

De basis bestaat uit een wiertal sets van twee bij elkaar behorende indicatoren. Op basis van deze indicatoren zijn de zogenaamde MBTI types geformeerd en met vier verschillende letters geïdentificeerd.

De positie van de verschillende letters is als volgt:

1 op de eerste positie staat de attitude-index: 'Extraversion (E) - Introversion (I)';

2 op de tweede positie staat de waarnemingsprocesindex: 'Sensing (S)-Intuition $(\mathrm{N})$;

3 op de derde positie staat de oordeelsvormingprocesindex: "Thinking ( $T$ )Feeling (F)';

4 op de vierde positie staat de voorkeursindex: 'Judging (0)-Perceiving (P)'.

Bij het lezen van de codes dienen de volgende stappen doorlopen te worden:

1 stel vast wat de vierde letter, de voorkeursindex, is:

- een J (Judging) wijst naar het oordeelsvormingproces, de derde letter;

- een P (Perceiving) wijst naar het waarnemingsproces, de tweede letter;

2 stel vast wat de eerste letter, de attitude-index, is. De verwijzing vanuit de voorkeursindex is gebaseerd op een extroverte situatie.

- geeft de attitude-index extrovert aan dan verwijst de voorkeursindex naar de dominante indicator;

- geeft de attitude-index introvert aan dan verwijst de voorkeursindex naar de secundaire indicator;

3 de indicator waarnaar de voorkeursindex niet verwijst is:

- in het geval de attitude-index extrovert aangeeft de secundaire indicator;

- in het geval de attitude-index introvert aangeeft de dominante indicator;

4 de als derde en vierde te boek staande indicatoren zijn de indicatoren uit het oordeelsvorming-en waarnemingsproces welke niet in de identificatie van het type is opgenomen. Als derde wordt benoemd de tegenpool van de secundaire indicator en als vierde de tegenpool van de dominante indicator.

Bij het doorlopen van de vorenstaande stappen ontstaat het volgende beeld wan een viertal types. 


\section{ESTY}

de voorketrsindex is aen J (Judgutent) en werwight nat de oordelswormigprocesindex $T$ (Thinking)

de attitude index is $\mathrm{E}$ (Extrovert) dus:

- het oordedsyoninugproces mat als indicator $T$ (Thinkmg is extrovert en dominatit;

- het wadnetwingsproces mer als indicator $S$ (Sensing) is introwert secundair.

Overige indicatorem:

- Het waarnemingsproces met als indicator N (Intu ition) is introvert en derde indicator;

- het oordeelsvormingproces met all indicator $F$ (Feeling is introvert an vierde indicator.

\section{ENFP}

de woorkeursindex is een $P$ (Perception) en verwijst natar de wamemingsprocesindex N (Intwition)

de attitude-index is E (Extrovert) dus:

- het warnemingsproce met als indicator N (Intuition) is extrovert en dominant;

- het oordeelsvormingproces met als indicator $F$ (Feeling) is introwert en secundair.

Overige indicatoren:

- het oordeelswormingproces me als indicator $\mathbb{T}$ (Thinktng is introvert en derde indicator;

- her warneringsproces me als indicator S (Sensing) is introvert en vierde indicator.

\section{IST)}

de wookentsindex is eer J (Judgunent) en verwijst nat de oorde elswomingprocesindex T (Thinking)

de atritude index is I (Iraverer) dus:

- het ootdeelsvormingproces met als indicator T (Thinkifug) is extrovert en secundain:

- het warnerningsproces met als indicator $\$$ (Sensing) is introvert en domimant.

Overige indicatoren:

- Het oordeelsvormingproces met als indicator $F$ (Feeling) is extrovert en derde indicator;

- het wamemingsproces met als indicator $N$ (nntuition) is extrovert en vierde indicator.

\section{INFP}

de vookeursindex he en P (Perception) en verwajtst natr de warnemingsprocesindex $\mathrm{N}$ (Intuition.)

de attitude-index is I (Introvert) dus:

- het waarnemingsproces met als indicator N (Inouthion) is extrovert en secundair;

- het oordeelsvomingproces met als indicator $F$ (Feeling) is introvert en dominant.

Orerige indicatoren:

- het wannemingsproces met als indicator $S$ (Sensing) is extrovert en derde indicator;

- het oordeelsvomingproces met als indicator $T$ (Thinking) is extrowert en viende indicator.

In de theorie wordt naar voren gebracht dat het meest vertrouwd wordt op de dominante indicator, die tevens het meest gebruikt wordt, het meest ontwikkeld wordt maar tevens vormbepalend is bij de persoonlijkheidsstructuur van het individu. De niet dominante indicatoren geven, afhankelijk van hun plaats, steeds ondersteuning aan het streven dat geïnitieerd wordt door de dominante indicator.

Ook hier kan weer gebruik worden gemaakt van de voorkeursterkte bij de validatie van de uitkomsten van een categorisatie. Hierbij vindt een vergelijking plaats van de voorkeursterkten van de dominante en de secundaire indicator plaats. Als stelregel geldt dat de voorkeursterkte van de dominante indicator altijd groter is dan die van de secundaire indicator. Hierbij moet rekening gehouden worden met het verschil in de waarderange dat anwezig is binnen de verschillende sets van indicatoren. Als de score van de dominante indicator veel lager is dan die van de secundaire indicator, en de indicator van de attitude-index of van de voorkeursindex is laag, zou wijziging van de indicator in de lage index wel eens tot betere resultaten kunnen leiden. Aan- 
getekend moet worden dat het geen wetmatigheid betekent. Het kan voor de onderzoeker een handreiking zijn bij het valideren van de uitkomsten van de categorisatie.

Binnen de categorisering volgens de MBTI ontstaan een zestiental verschillende types waarbij het leespatroon in onderstaande figuur is weergegeven.

Het is niet eenvoudig exact te omschrijven wat de karakteristieken zijn van de verschillende combinaties van waarnemings- en oordeelsvormingprocessen en daarbinnen de verschillende plaatsen van de indicatoren. Niet alleen de plaats van een indicator maar ook de waarde die zij hebben verkregen op basis van de beantwoording van de vragen dient bij de categorisering te worden meegenomen. Voorts wordt nogmaals benadrukt dat ook in de tijd gezien veranderingen kunnen optreden in het type waarin een individu wordt ingedeeld, dan wel de waarde welke de verschillende indicatoren hebben [Schachner Chanen, 2000]. Dit is weer het gevolg van de ontwikkeling welke het individu doormaakt en de verschillende stimuli waaraan hij bloot staat. Dit is overeenkomstig hetgeen gesteld is ten aanzien van de ontwikkeling van het "professional judgment". De gevolgde opleiding en de opgedane ervaringen hebben zo niet alleen een directe invloed op de zich ontwikkelende kennis maar zullen tevens invloed hebben op de ontwikkeling van de gevoeligheidssterkten van de verschillende indicatoren en daarmee op het soort type waartoe men behoort. In de hierna volgende twee tabellen is een algemene beschrijving van de verschillende types opgenomen. 


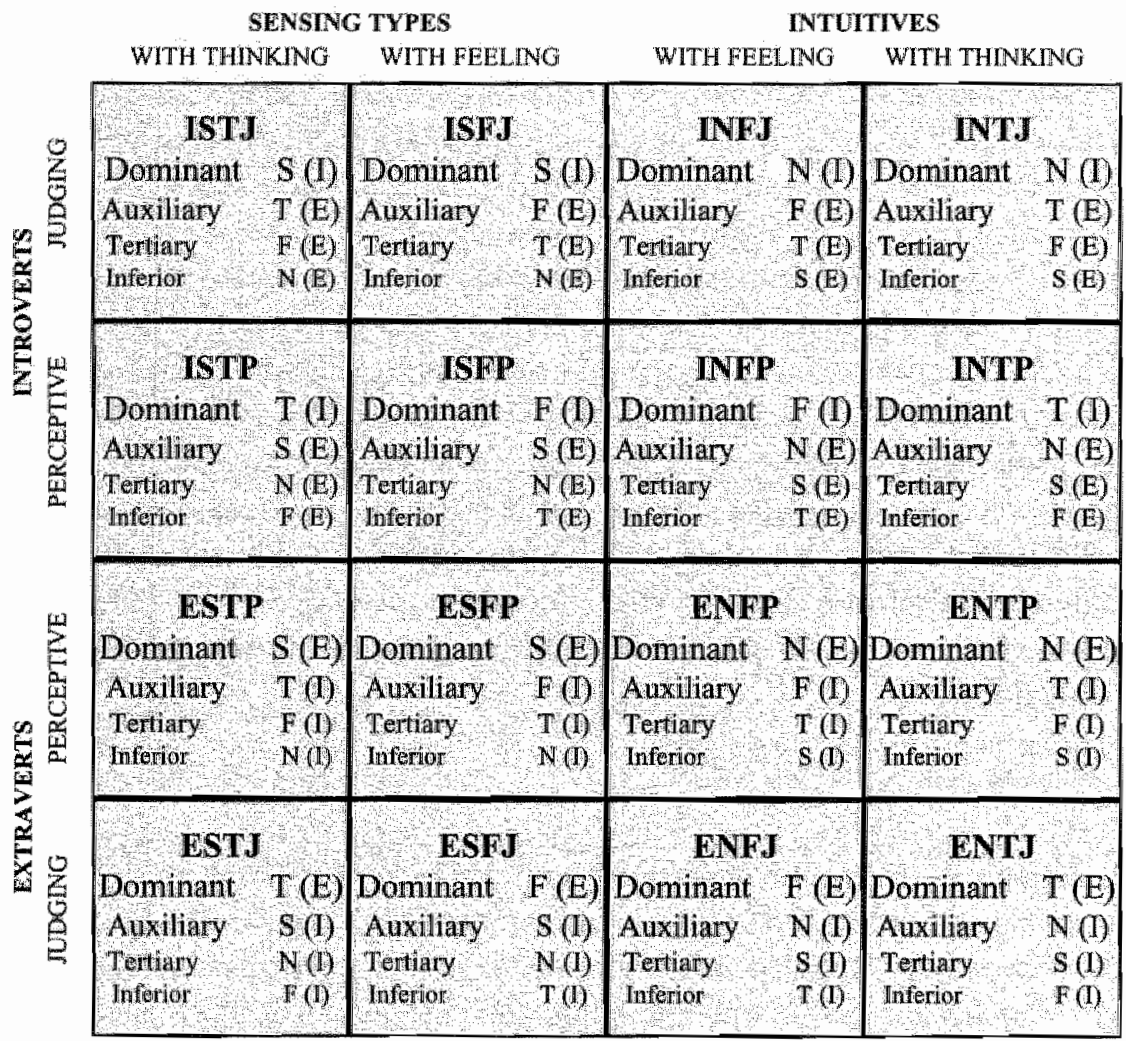

Serious, quidet, warn suecess by concentration and thom Quiet, friendly, responsible, and conscientious. Work. roughuess. Practical, orderly, mater-of-fact, logical, devotedly to neet their obligations. Lend stability to realistic, and dependable. See to it that everything is any project or group. Thorough, painstaking, accuwhell organized. Take responsibility. Make up their rate. Their interests are usually not techaical. Can be own minds as to what should be incomplished and patent with necessary details. Loyal, considerate, perwork toward it stendily, regardless of protests or dis- ceptive, concerned with how other people feel. unctions.

Live their outer life nore whth thinking, inner more Live their outer life nore with feling, inner more with sensing. with sensing. 
Cool onlookers, quiet, reserved, observing and analyw zing life with detached curiosity and unexpected flashes of original humor. Usually interested in cause and effect, how and why rnechanical things work, and in organizung facts using logical principles.
Retiring, quiedly friendly, sensitive, kind, and modest about their abilinies. Shun disagreements; do not force their opinions or values on others. Usually do not care. to lead but are often loyal followers. Often relaxed about getting things done, because they enjoy the present moment and do not want to spoil it by undue haste or exertion.

Live their ofuter life more with sensing, inner more with thinking.

\section{Sensing / Extraversion}

\section{ESTP}

\section{ESFP}

Good at on-the-spot problem solving. Do not worry, Outgoing, easygoing, accepting, friendly, enjoy eveenjoy whatever comes along. Tend to like mechanical rything and make things more fun for others by their things and sports, with friends on the side. Adaptable, enjoyment. Like sports and making things happen tolerant, generally conservative in values. Dislike long Krow what's going on and join in eagerly. Find explanations. Are best with real things that can be remembering facts easier than mastering theories. Are worked, handled, taken apart, or put together. best is situations that need sound common sense and practical ability with people as well as with things.

Live their outer life more with sensing, inner more Live their outer life more with sensing, inner more with thinking. with feeling

\section{ESTIJ}

\section{ESFJ}

Practical, realistic, matcer-of-fact, with a natural head Warm-hearted, talk active, popular, conscientions, for business or mechanics. Not interested in subjects born cooperators, active committee members. Need they see no use for, but can apply themselves with harmony and may be good at creating it. Always necessary. Like to organize and run activities. May doing something nice for someone. Work best with make good administrators, especially if they remem- encouragement and praise. Main interest is in things ber to consider others' feelings and points of view. that directly and visibly affect people's lives.

Live their outer life more with thinking, inner more Live their outer life more with feeling, inner more with sensing. with sensing.

Based on Ancona, Kochan, Scully, Van Maanen \& Westmey, Mathing for whe Futur, Southw Westetn College Publishers, 1996

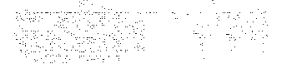

\section{INFJ}

Succeed by perseverance, originality, and desire to do whatever is needed on wanted. Put their best efforts into their work. Quietly forceful, corscientious, concerned for others. Respected for their firm principles. Likely to be honored and followed for their clear convictions as to how best to serve the common good.

Live their outer life more with feeling, inner more with intuition.

\section{Intuition / Introversion}

\section{INTJ}

Ustally have original minds and great drive for their own ideas and purposes. In felds that appeal to them. they have a fine power to organize a job and carry it through with or without help. Sceptical, critical, independent, determined, sometimes stubborn. Must learn to yield less important points in order to win the most important.

Live their outer life more with thinking, inner more with intuition. 


\section{INFP}

Full of enthusiasms and loyalties, but seldorn talk of these until they know you well. Care about learning. ideas, language, and independent projects of their own. Tend to undertake too much, and then somehow get it done Friendly, but often too absombed in what they are doing to be sociatlse. Little concerned with possessions or physical surroundings.

Live their outer life more with intuition, inner more with feeling.

\section{INTP}

Quiet and reserved. Especially enjoy theoretical or scientific pursuits. Like solving problemss with logic and andlysis. Usually interested mainly in ideas, with little liking for parties or small talk. Tend to have sharply defined interests. Need careers where some strong interest can be used awns useful.

Live their outer life more with intuition, imner more with thinking.

\section{ENFP}

Warmly enthusiastic, high-spirited, imgenous, imagmatwe. Able to do almost anything that interests them. Quick with at solution for any difficulty and ready to help anyone with a problem. Often rely on their abiulity to improvise instead of preparing in advance. Can usually find compelling reasons for whatewer they want.

Live their outer life more whin intuition, inner more with feeling.

\section{ENFI}

Responsive and responsible. Generally feel real conceru for what others think or want and try to handle things with due regard for the other person "s feelings. Can present a proposal or lead a group discussion with ease and tact Sociable, popular, sympatheric. Responsive to praise and criticism.

Live their outer life more with feeling inner more with intulition.

\section{ENTP}

Quick, ingenious, good at many things. Stimulating company, alert and otutspoken. May argue for fun either side of a question. Resourcetul in solving new and challenging problenus, but nay neglect routine assignments. Apt to kurn to one new interest after another. Skillful in finding logical reasons for what they want.

Live their onter life more with intution, inner more with thinking.

\section{ENTI}

Hearty, frink, decisive, leaders in activities. Usually good in anything that requires reasoning and intelligent talk, such as public speaking. Are wsually well informed and enjoy adding to their fund of knowa ledge. May sometimes appear more positive and confdent than their experience in an area warrants.

Live their outer life more with thinking, inner more with intuition.

Based on Ancona, Kochan, Scully, Van Maanen ge Westney, Mandging, for the Fufure, Sonth-Western College Publiskers, 1996 


\section{Bijlage 10: Overzicht beoordeelde casusstellingen}

\begin{tabular}{|c|c|c|}
\hline Castusstelling & Aantallen & Bijdrage aan verzameling onderzoeksgegevens \\
\hline OR001 & 22 & $4,17 \%$ \\
\hline OR002 & 15 & $2,85 \%$ \\
\hline OR003 & 19 & $3,61 \%$ \\
\hline OR004 & 14 & $2,66 \%$ \\
\hline OROO5 & 14 & $2,66 \%$ \\
\hline OROOO6 & 15 & $2,85 \%$ \\
\hline OR007 & 17 & $3,23 \%$ \\
\hline OR008 & 13 & $2,47 \%$ \\
\hline OROOO & 18 & $3,42 \%$ \\
\hline OR010 & 13 & $2,47 \%$ \\
\hline OR011 & 15 & $2,85 \%$ \\
\hline OR012 & 14 & $2,66 \%$ \\
\hline OR013 & 13 & $2,47 \%$ \\
\hline OROL 4 & 16 & $3,04 \%$ \\
\hline OR015 & 13 & $2,47 \%$ \\
\hline OR016 & 23 & $4,36 \%$ \\
\hline OR017 & 14 & $2,66 \%$ \\
\hline OR018 & 20 & $3,80 \%$ \\
\hline OR019 & 20 & $3,80 \%$ \\
\hline OR020 & 19 & $3,61 \%$ \\
\hline OR021 & 25 & $4,74 \%$ \\
\hline OR022 & 12 & $2,28 \%$ \\
\hline OR023 & 15 & $2,85 \%$ \\
\hline OR024 & 12 & $2,28 \%$ \\
\hline OR025 & 15 & $2,85 \%$ \\
\hline OR026 & 16 & $3,04 \%$ \\
\hline OR027 & 20 & $3,80 \%$ \\
\hline OR028 & 23 & $4,36 \%$ \\
\hline OR029 & 14 & $2,66 \%$ \\
\hline OR030 & 19 & $3,61 \%$ \\
\hline OR031 & 16 & $3,04 \%$ \\
\hline OR 032 & 13 & $2,47 \%$ \\
\hline Totalen & 527 & $100,00 \%$ \\
\hline
\end{tabular}




\section{Bijlage 11: Verdeling 'Voorkompercentages' per casusstelling}

$\begin{array}{lccccccccccccc}\text { Canits } & 0 \% & \mathbf{1 0 \%} & \mathbf{1 5 \%} & \mathbf{2 0 \%} & \mathbf{3 0 \%} & \mathbf{4 0 \%} & \mathbf{5 0 \%} & \mathbf{6 0 \%} & \mathbf{7 0 \%} & \mathbf{8 0 \%} & \mathbf{9 9 \%} & \text { antal } \\ \text { OR001 } & 7 & 11 & 0 & 0 & 1 & 1 & 0 & 2 & 0 & 0 & 0 & 22 \\ \text { OR002 } & 3 & 4 & 1 & 1 & 1 & 3 & 1 & 1 & 0 & 0 & 0 & 15 \\ \text { OR003 } & 6 & 3 & 0 & 6 & 1 & 2 & 0 & 1 & 0 & 0 & 0 & 19 \\ \text { OR004 } & 5 & 1 & 0 & 2 & 1 & 4 & 0 & 0 & 1 & 0 & 0 & 14 \\ \text { OR005 } & 6 & 2 & 0 & 0 & 1 & 2 & 2 & 0 & 1 & 0 & 0 & 14 \\ \text { OR006 } & 2 & 6 & 0 & 0 & 2 & 2 & 1 & 0 & 2 & 0 & 0 & 15 \\ \text { OR007 } & 5 & 1 & 0 & 1 & 4 & 3 & 1 & 1 & 1 & 0 & 0 & 17 \\ \text { OR008 } & 4 & 4 & 0 & 1 & 1 & 2 & 0 & 1 & 0 & 0 & 0 & 13 \\ \text { OR009 } & 4 & 2 & 0 & 1 & 2 & 4 & 5 & 0 & 0 & 0 & 0 & 18 \\ \text { OR010 } & 4 & 4 & 0 & 2 & 1 & 1 & 0 & 1 & 0 & 0 & 0 & 13 \\ \text { OR011 } & 4 & 1 & 0 & 3 & 2 & 2 & 0 & 1 & 2 & 0 & 0 & 15 \\ \text { OR012 } & 4 & 2 & 0 & 3 & 1 & 0 & 2 & 1 & 0 & 1 & 0 & 14 \\ \text { OR013 } & 5 & 2 & 0 & 3 & 1 & 1 & 1 & 0 & 0 & 0 & 0 & 13 \\ \text { OR014 } & 4 & 3 & 0 & 1 & 2 & 2 & 1 & 1 & 1 & 1 & 0 & 16 \\ \text { OR015 } & 0 & 2 & 0 & 6 & 4 & 0 & 1 & 0 & 0 & 0 & 0 & 13 \\ \text { OR016 } & 6 & 6 & 0 & 3 & 1 & 4 & 2 & 0 & 0 & 1 & 0 & 23 \\ \text { OR017 } & 4 & 2 & 0 & 0 & 2 & 3 & 0 & 0 & 2 & 1 & 0 & 14 \\ \text { OR018 } & 2 & 4 & 0 & 1 & 2 & 3 & 1 & 2 & 3 & 2 & 0 & 20 \\ \text { OR019 } & 4 & 4 & 0 & 1 & 2 & 3 & 1 & 2 & 2 & 1 & 0 & 20 \\ \text { OR020 } & 7 & 3 & 0 & 1 & 1 & 1 & 2 & 1 & 2 & 0 & 1 & 19 \\ \text { OR021 } & 3 & 7 & 0 & 4 & 3 & 2 & 2 & 2 & 2 & 0 & 0 & 25 \\ \text { OR022 } & 4 & 1 & 0 & 2 & 0 & 3 & 1 & 0 & 1 & 0 & 0 & 12 \\ \text { OR023 } & 5 & 2 & 0 & 2 & 1 & 3 & 0 & 1 & 0 & 1 & 0 & 15 \\ \text { OR024 } & 2 & 4 & 0 & 3 & 2 & 0 & 1 & 0 & 0 & 0 & 0 & 12 \\ \text { OR025 } & 2 & 0 & 0 & 5 & 2 & 2 & 3 & 0 & 0 & 1 & 0 & 15 \\ \text { OR026 } & 5 & 2 & 0 & 2 & 2 & 2 & 0 & 1 & 2 & 0 & 0 & 16 \\ \text { OR027 } & 2 & 5 & 0 & 1 & 4 & 3 & 2 & 1 & 1 & 1 & 0 & 20 \\ \text { OR028 } & 7 & 3 & 0 & 3 & 1 & 1 & 3 & 4 & 1 & 0 & 0 & 23 \\ \text { OR029 } & 1 & 3 & 0 & 2 & 2 & 4 & 0 & 2 & 0 & 0 & 0 & 14 \\ \text { OR030 } & 4 & 2 & 0 & 4 & 4 & 0 & 3 & 2 & 0 & 0 & 0 & 19 \\ \text { OR031 } & 6 & 3 & 0 & 2 & 2 & 0 & 3 & 0 & 0 & 0 & 0 & 16 \\ \text { OR032 } & 3 & 2 & 0 & 1 & 2 & 0 & 2 & 0 & 3 & 0 & 0 & 13 \\ \text { Totaal } & 130 & 101 & 1 & 67 & 58 & 63 & 41 & 28 & 27 & 10 & 1 & 527\end{array}$




\section{Bijlage 12: Overzicht beoordeelde casusstellingen en beheersingsmaatregelen}

\begin{tabular}{|c|c|c|c|c|c|c|}
\hline Casus & Aantal & $\begin{array}{l}\text { Proces } \\
\text { (P) }\end{array}$ & $\begin{array}{c}\text { Financieel } \\
(\mathrm{F})\end{array}$ & $\begin{array}{l}\text { Organisatie } \\
\text { (O) }\end{array}$ & $\begin{array}{c}\text { Informatis } \\
\text { (I) }\end{array}$ & $\begin{array}{c}\text { Prestatie } \\
\text { (E) }\end{array}$ \\
\hline ORO01 & 22 & 22 & 22 & 22 & 22 & 22 \\
\hline OROO2 & 15 & & 15 & 15 & 15 & 15 \\
\hline OR003 & 19 & 19 & 19 & 19 & & 19 \\
\hline OR004 & 14 & 14 & 14 & 14 & 14 & \\
\hline OR005 & 14 & 14 & & 14 & 14 & 14 \\
\hline ORO06 & 15 & 15 & 15 & & 15 & 15 \\
\hline OR007 & 17 & & 17 & 17 & & 17 \\
\hline OR008 & 13 & & 13 & 13 & 13 & \\
\hline OR009 & 18 & & & 18 & 18 & 18 \\
\hline OR010 & 13 & & 13 & & 13 & 13 \\
\hline OR011 & 15 & 15 & 15 & 15 & & \\
\hline OR012 & 14 & 14 & & 14 & & 14 \\
\hline OR013 & 13 & 13 & 13 & & & 13 \\
\hline OR014 & 16 & 16 & & 16 & 16 & \\
\hline OR015 & 13 & 13 & 13 & & 13 & \\
\hline OR016 & 23 & 23 & & & 23 & 23 \\
\hline OR017 & 14 & & 14 & 14 & & \\
\hline OR018 & 20 & & & 20 & & 20 \\
\hline OR019 & 20 & & 20 & & & 20 \\
\hline OR020 & 19 & & & 19 & 19 & \\
\hline OR021 & 25 & & 25 & & 25 & \\
\hline OR022 & 12 & & & & 12 & 12 \\
\hline OR023 & 15 & 15 & & 15 & & \\
\hline OR024 & 12 & 12 & 12 & & & \\
\hline OR025 & 15 & 15 & & & & 15 \\
\hline OR026 & 16 & 16 & & & 16 & \\
\hline ORLO27 & 20 & & & 20 & & \\
\hline OR028 & 23 & & 23 & & & \\
\hline OR029 & 14 & & & & & 14 \\
\hline OR030 & 19 & & & & 19 & \\
\hline OR031 & 16 & 16 & & & & \\
\hline Or032 & 13 & & & & & \\
\hline Totaal & $527 / 1311$ & 252 & 263 & 265 & 267 & 264 \\
\hline Relatief & $100 \%$ & $19,2 \%$ & $20,1 \%$ & $20,2 \%$ & $20,4 \%$ & $20,1 \%$ \\
\hline
\end{tabular}




\section{Bijlage 13: Overzicht gegeven waardeoordelen en consensuswaarden}

\begin{tabular}{|c|c|c|c|c|c|c|c|c|c|c|c|c|c|c|c|}
\hline$c$ & B & $\mathrm{B}$ & $\mathrm{cw}$ & B & $\mathrm{CW}$ & B & CW & B & $\mathrm{cW}$ & B & $\mathrm{CW}$ & B & $\mathrm{CW}$ & B & $\mathrm{cw}$ \\
\hline Oro01 & 22 & 2 & 9,1 & 13 & 6. & 6 & 27.3 & 1 & 4,5 & & & & & & \\
\hline OR002 & 15 & 2 & 13,3 & 4 & 26.7 & 6 & 40 & 2 & 13,3 & $\|$ & 6.7 & & & & \\
\hline OR003 & 19 & 4 & 21,1 & 7 & 36,8 & 6 & 31,6 & 2 & 10,5 & & & & & & \\
\hline Oroo4 & 14 & 3 & 21,4 & 3 & 21.4 & 5 & 35,6 & 1 & 7,2 & 1 & 7,2 & 1 & 7,2 & & \\
\hline Oro05 & 14 & 3 & 21,4 & 5 & 35,7 & $\mathbb{1}$ & 7,2 & 4 & 28,5 & 1 & 7.2 & & & & \\
\hline OR006 & 15 & & & 2 & 13,3 & 7 & 46,7 & 2 & 13,3 & 4 & 26.7 & & & & \\
\hline OR007 & 17 & & & 4 & 23,5 & 4 & 23,5 & 4 & 23,5 & 4 & 23,5 & 1 & 6,0 & & \\
\hline OR008 & 13 & 1 & 7,7 & 5 & 38,5 & 2 & 15,3 & 4 & 30,8 & & & 1 & 7,7 & & \\
\hline OR009 & 18 & & & 6 & 33,3 & 6 & 33,3 & 6 & 33,4 & & & & & & \\
\hline OR010 & 13 & & & 2 & 15,3 & 6 & 46,2 & 1 & 7,7 & 3 & 23,1 & 1 & 7,7 & & \\
\hline OR011 & 15 & & & 5 & 33,3 & 7 & 46,7 & 2 & 13,3 & 1 & 6,7 & & & & \\
\hline OR01.2 & 14 & 1. & 7,1 & 6 & 42,9 & 5 & 35,7 & 2 & 14,3 & & & & & & \\
\hline OR013 & 13 & 3 & 23,1 & 3 & 23,1 & 3 & 23,1 & 2 & 15,3 & 1 & 7,7 & 1 & 7,7 & & \\
\hline OR014 & 16 & 2 & 12,4 & 6 & 37.5 & 6 & 37,5 & 1 & 6,3 & 1 & 6,3 & & & & \\
\hline OR015 & 13 & 2 & 15,3 & 3 & 23,1 & 4 & 30,8 & $\mathbb{1}$ & 7.7 & 3 & 23,1 & & & & \\
\hline OR016 & 23 & 4 & 17.4 & 2 & 8.7 & 11 & 47,8 & 3 & 13,0 & 2 & 8,7 & 1 & 4,4 & & \\
\hline ORO17 & 14 & 2 & 14.3 & 3 & 21,4 & 4 & 28,6 & 3 & 21,4 & 2 & 14,3 & & & & \\
\hline OROA & 20 & 1 & 5 & 5 & 25 & 6 & 30 & 4 & 20 & 3 & 15 & $\mathbb{1}$ & 5 & & \\
\hline OR019 & 20 & & & 3 & 15 & 9 & 45 & 4. & 20 & 3 & 15 & & & 1 & 5 \\
\hline ORO20 & 19 & & & 4 & 21,0 & 8 & 42,1 & 5 & $26 n^{3}$ & 1 & 5,3 & 1 & 5,3 & & \\
\hline OR021 & 25 & & & 2 & 8 & 8 & 32 & 2 & 8 & 11 & 44 & 2 & 8 & & \\
\hline OR022 & 12 & & & 2 & 16.7 & 5 & 41,7 & 1 & 8,3 & 3 & 25 & 1 & 8,3 & & \\
\hline OR023 & 15 & 1 & 6,7 & 4 & 26,7 & 5 & 33,3 & 2 & 13.3 & 3 & 20 & & & & \\
\hline OR024 & 12 & & & 2 & 16,7 & (2) & $(56,)^{2}$ & & & 2 & 16,7 & 1 & 8,3 & & \\
\hline OR025 & 15 & 3 & 20 & 7 & 46,7 & 2 & 13,3 & 2 & 13,3 & 1 & 6,7 & & & & \\
\hline
\end{tabular}




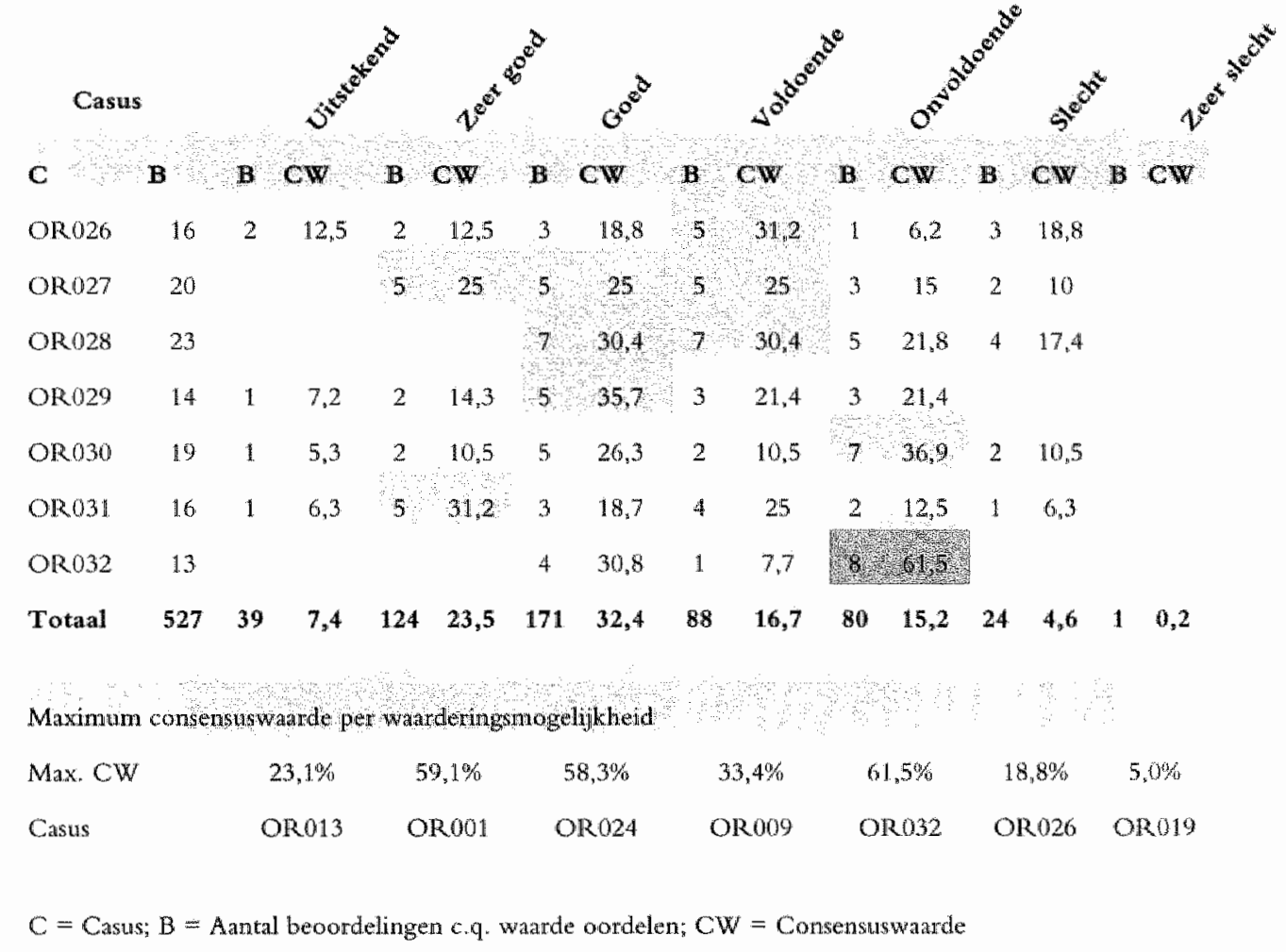

Hoogste consencuswatrde per casusstelling

Hoogste consenususwaarda $>50 \%$ 


\section{Bijlage 14: Overzicht gegeven waardeoordelen, diverse dwarsdoorsneden}

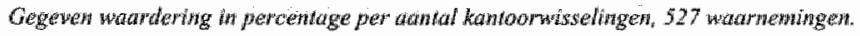

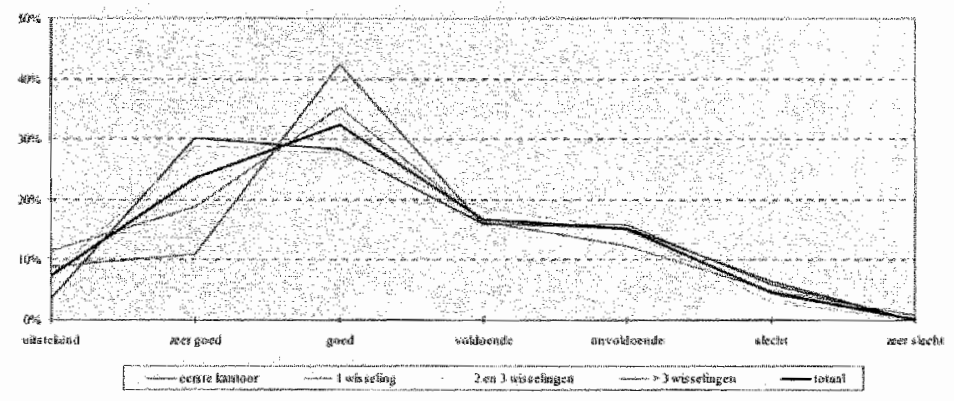

Gegeven waardering in percentage per enaringsiarew, 78 watheningen.

De groep $30-\$ 0$ jaar ervaring is wegens hat kleine antal waarderïngen, te weten 49 , niet in de grafiek opgenomen.

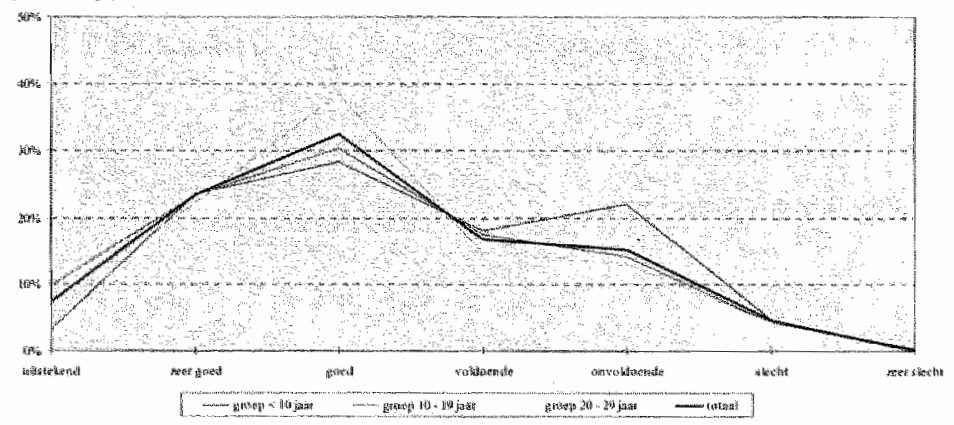


Gegeven wardering in percentoge woor whe leefijdsgropen. 428 wamemingen.

De groepen $25-29$ jaar en $50-77$ jaar zijn wegens het klewne aantal waarderingen, te weten 39 respectievelijk 60 . niet in de grafiek opgenomen.

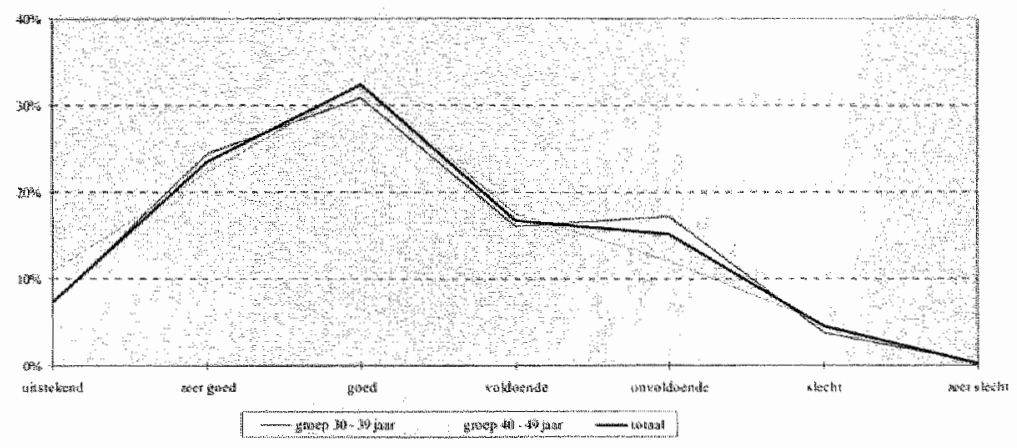

Gegeven wardering in perceniage per soort oplleiding, 525 watphemingen.

Een tweetal accountants ieder met én beoordeling, hebben een andere opleiding opgegeven

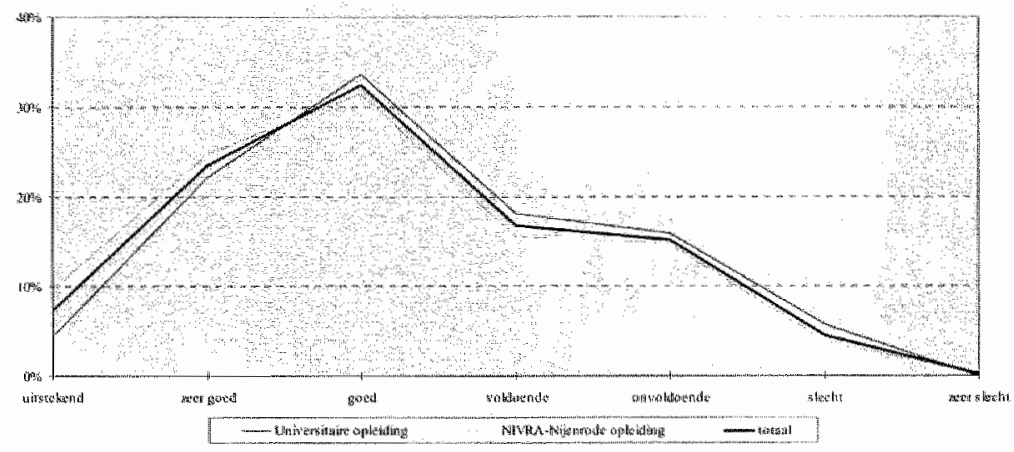

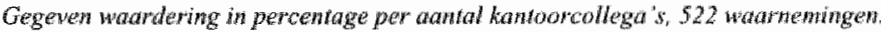
Van éen accountant met een wijftal beoordelingen is dit gegeven oabekend.

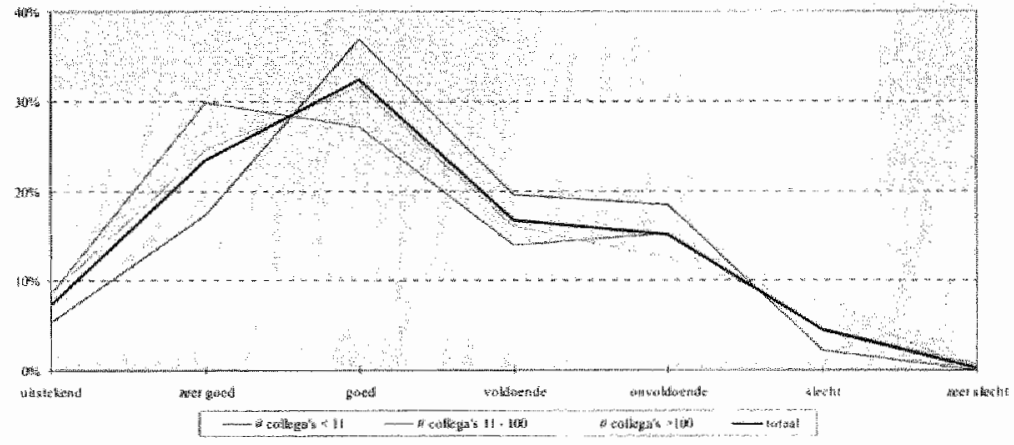




\section{Bijlage 15: Verdeling waardeoordelen per ervaringsjaren en beoordelingswaarden}

\begin{tabular}{|c|c|c|c|c|c|c|c|c|c|}
\hline \multicolumn{10}{|l|}{$\begin{array}{l}\text { Aantal soorten } \\
\text { beheersingsimaatregelen }\end{array}$} \\
\hline 5 beherersingsinatatregelen & 3 & & 3 & & & & & & 6,0000 \\
\hline 4. beheersingsinatregelen & 22 & & 6 & 10 & 3 & 3 & & & 4,8636 \\
\hline 3 beheersingsmatragelen & 36 & 3 & 12 & 10 & 7 & 3 & 1 & & 5,0556 \\
\hline 2 beheersingmanatregelen & 34 & 1 & 5 & 9 & 5 & 12 & 2 & & 4,1765 \\
\hline 1. beheersingsunaatregel & 27 & & 4 & 6 & 7 & 7 & 3 & & 4,0370 \\
\hline Geen beheersingsmatregel & 5 & & & 1. & $\mathbb{1}$ & 3 & & & 3,6000 \\
\hline Totaal & 127 & 4 & 30 & 36 & 23 & 28 & 6 & 0 & 4,5354 \\
\hline \multicolumn{10}{|l|}{ 10 tot en met 19 jatr } \\
\hline 5 beheersingsmatregetlen & 10 & 2 & 5 & 3 & & & & & 5,9000 \\
\hline 4 beheersingsmatregelen & 28 & 8 & 6 & 7 & 4 & 3 & & & 5,4286 \\
\hline 3 beheersingsmatregelen & 70 & 7 & 18 & 20 & 12 & 9 & 4 & & 4,8571 \\
\hline 2 beheersingsratatregelen & 84 & 3 & 21 & 30 & 15 & 11 & 3 & 1 & 4,7262 \\
\hline 1 beheersingsmaatregel & 37 & 3 & 5 & 9 & 10 & 7 & 3 & & 4,4054 \\
\hline Geen beheersingsmaatiegel & 5 & & & 2 & & 3 & & & 3,8000 \\
\hline Total & 234 & 23 & 55 & 71 & 41 & 33 & 10 & 1 & 4,8291 \\
\hline \multicolumn{10}{|l|}{20 tot en met 29 Jaar } \\
\hline 5 beh้eersingsmatregelen & 8 & & 4 & 3 & 1 & & & & 5,3750 \\
\hline 4 beheersingsmatregelen & 19 & 4 & 6 & 6 & 1 & 1 & 1 & & 5,4211 \\
\hline 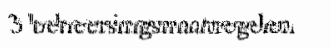 & $34:$ & 3 & 7 & 16 & 6 & 2 & & & 5,0882 \\
\hline 2 beheervingswatregelen & 35 & 2 & 6 & 13 & 6 & 5 & 3 & & 4,5714 \\
\hline 1 beheersingsmaatregel & 19 & & 3 & 7 & 3 & 5 & 1 & & 4,3158 \\
\hline Geen beheersingernatregel & 2 & & & & & 2 & & & 3,0000 \\
\hline Totaal & 117 & 9 & 26 & 45 & 17 & 15 & 5 & 0 & 4,8462 \\
\hline \multicolumn{10}{|l|}{30 tot en met 50 jaar } \\
\hline Sbehtersingsmatregelen & $\|$ & & $\mathbb{1}$ & & & & & & 6,0000 \\
\hline 4 beheersingsmatregelen & 8 & & 3 & 2 & 3 & & & & 5,0000 \\
\hline 3 beheersingsmatregelen & 15 & & 5 & 8 & 1. & 1 & & & 5,1333 \\
\hline 2 belneersingsmatregelen & 1.5 & 3 & 2 & 5 & 2 & 2 & 1 & & 4,9333 \\
\hline I beheersingmaatecell & 9 & & 2 & 3 & 1 & 1 & 2 & & 4,2222 \\
\hline Geen beheersingsmaatregel & 1 & & & 1 & & & & & 5,0000 \\
\hline Totmal & 49 & 3 & 13 & 19 & 7 & 4 & 3 & 0 & 4,8980 \\
\hline
\end{tabular}




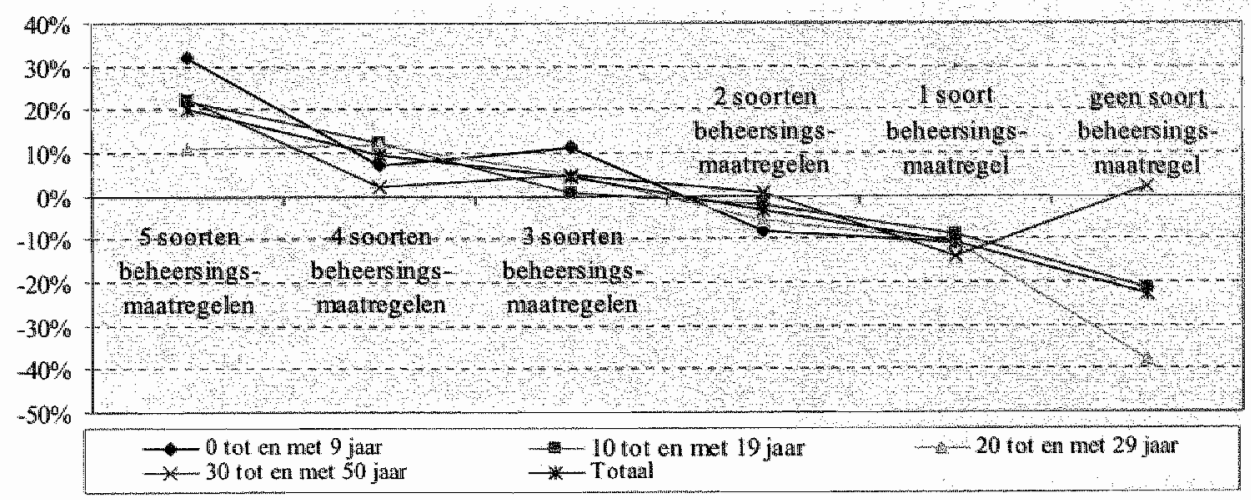

Procentuele verloop van de beoordelingswarden per subselecrie 'jaren warkervaring' ten opzichte van de totale beoordelingswarde van die selectie en de totale beoordelingswarde van de totale populatie. 


\section{Bijlage 16: Verdeling waardeoordelen per beheersingsmaatregel en beoordelingswaarden}

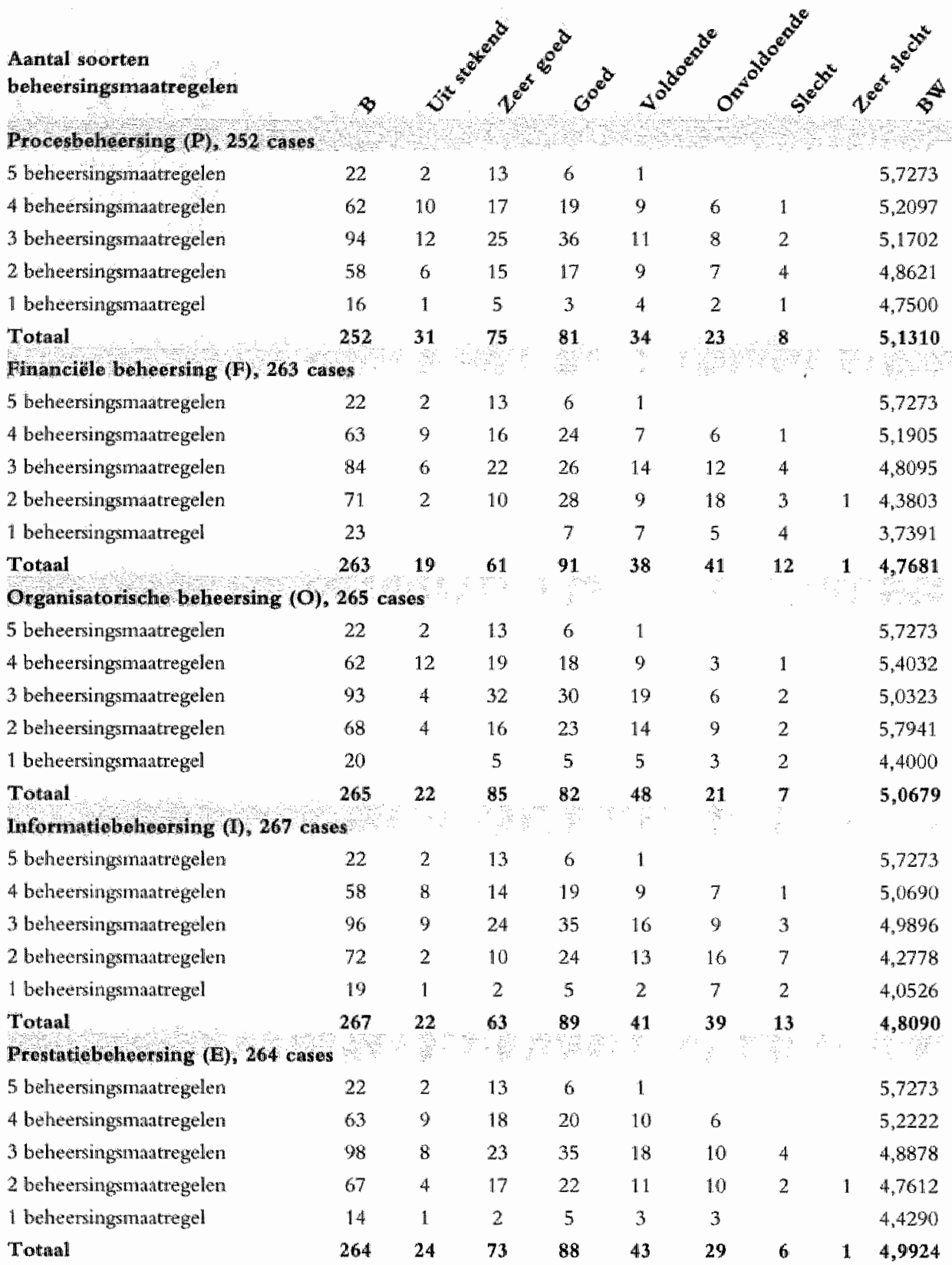




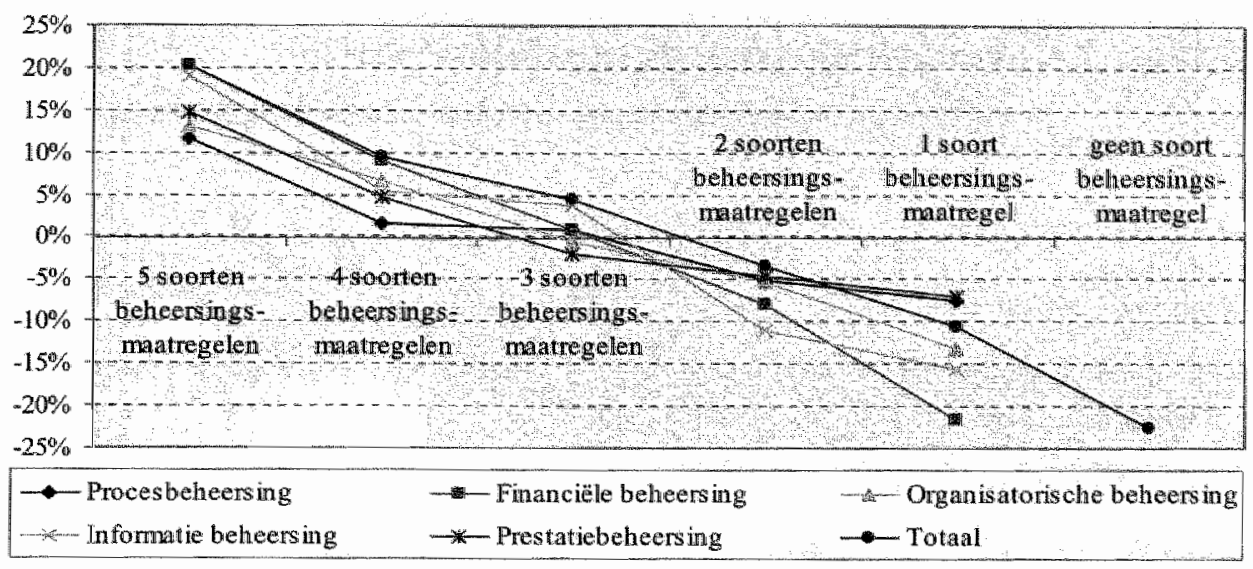

Procentuele verloop van de beoordelingswarden per subselectie "soort beheersingsmantregel" ten opzictlte van de totale beondelingswarde varx die selectie en de totale beoordelingwwaarde van de totale populatie. 


\section{Bijlage 17: Verdeling waardeoordelen per voorkompercentage en beoordelingswaarden}

\section{Aantali soorten beheersingsmaatregelen}

Voorkonipercentage $0-20 \%$

5 behersingsnatregelen

4 beheeringsinatregelen

3 beheersingsmaatregelen

2 beheersingstatategelen

1. beheorsingmatrogel

Geen beheersingsmatregel

"ilotaral:

Voorkonmpercentage $21-40 \%$

5 behersingsmaatragelen

4. beheersingsmatregelen

3 beheersingsmatregelen

2 beheersingsmaatregelen

1. beheersingsmatregel

Geen beheersingsmatregel

\section{Totaal}

Voorkompereentagge $41-60 \%$

5 beheersingsmaatregelen

4. beheersingsmaatregalen

3. behersingsmatregelen

2 beheersingsmatregelen

1 behersingswatreysel

Geen beheersingsmatregel

Totanl

Vookkonpetcentage $61-80 \%$

5 beheersingsmatregelen

4 behentingsmantregelen

3 bohersingsmatregelen.

2 behetringmatregelen

$\forall$ bethersingsmatrey

Geen beheersingmantriegel

Totanal

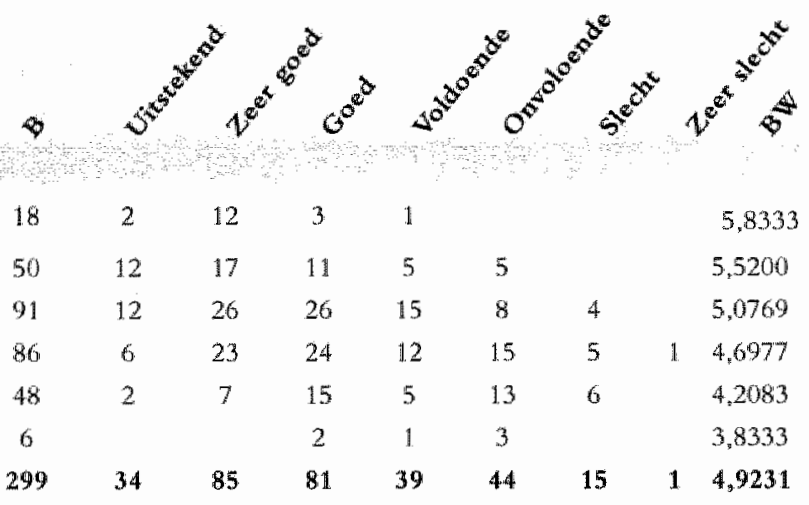

$\begin{array}{cccccccc}2 & & 1 & 1 & & & & 5,5000 \\ 19 & 2 & 4 & 8 & 3 & 1 & 1 & 5,0000 \\ 38 & 1 & 8 & 14 & 8 & 7 & & 4,6842 \\ 40 & 1 & 5 & 18 & 7 & 7 & 2 & 4,5000 \\ 20 & & 4 & 4 & 7 & 4 & 1 & 4,3000 \\ 2 & & & 1 & & 1 & & 4,0000 \\ 121 & 4 & 22 & 46 & 25 & 20 & 4 & 4,6116\end{array}$

\begin{tabular}{|c|c|c|c|c|c|c|c|}
\hline 2 & & & 2 & & & & 5,0000 \\
\hline 6 & & & 2 & 3 & $\mathbb{1}$ & & 4,1667 \\
\hline 19 & & 5 & 11 & 2 & & 1 & 5,0000 \\
\hline 20 & & 3 & 5 & 6 & 5 & 1 & 4,2000 \\
\hline 20 & 1 & 3 & 4 & 9 & 1 & 2 & 4,4000 \\
\hline 2 & & & 1 & & 1 & & 4,0000 \\
\hline 69 & 1 & 11 & 25 & 20 & 8 & 4 & 4,4928 \\
\hline
\end{tabular}

$\begin{array}{ccccccc}4 & & 4 & & & & 5,0000 \\ 7 & 3 & 3 & 1 & & & 5,2857 \\ 20 & 3 & 9 & 3 & 4 & 1 & 4,4500 \\ 3 & & 2 & & 1 & & 4,3333 \\ 3 & & & & 3 & & 3,0000 \\ 37 & 6 & 18 & 4 & 8 & 1 & 4,5405\end{array}$




\section{Aantal soorten} beheersingsmaatregelen

Voorkompercentage $81-100 \%$

5 beheersingsmaatregelen

4 beheersingsmaatregelen

3. beheersingsmatregelen

2 beheersingsmaatregelen

1 beheersingsmaatregel

Geen beheersingsmatregel

Totaal

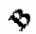
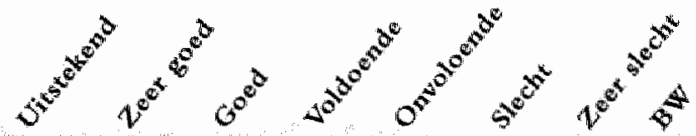

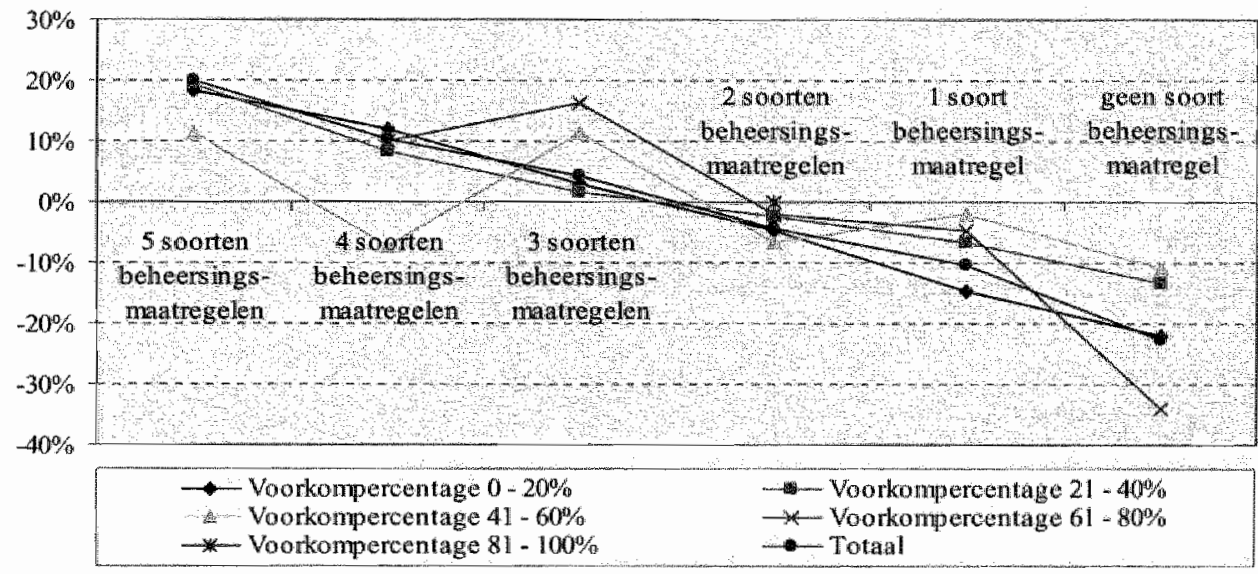

Procentuele verloop wan de beoordelingswarden per subselecte "voorkompercentage" tern opzichte van de totale beoordelingswarde wan die selectie en de totale beoordelingswarde van de totale populatie. 


\section{Bijlage 18: Verdeling waardeoordelen per voorkeur en beoordelingswaarden}

\begin{tabular}{|c|c|c|c|c|c|c|c|c|c|}
\hline \multicolumn{10}{|c|}{$\begin{array}{l}\text { Aantal sowrten } \\
\text { beheersingsumatregelem } \\
\text { Procesbeheersing (P), } 319 \text { cases }\end{array}$} \\
\hline 5 beheersingenaatregelen & 16 & 2 & 9 & 4 & 1 & & & & 5.7500 \\
\hline 4 beheersingsimatregelen & 43 & 7 & 1.2 & 13 & 5 & 5 & 1 & & 5,1860 \\
\hline 3 belwersingsmatregelen & 91 & 8 & 22 & 33 & 16 & 11 & 1 & & 4,9670 \\
\hline 2 beheensingsmatregelen & 104 & 3 & 17 & 37 & 17 & 22 & 7 & 1 & 4,3942 \\
\hline 1 beheersingsmatregel & 57 & 2 & 7 & 18 & 11 & 14 & 5 & & 4,2456 \\
\hline Geen beheersingsmatregel & 8 & 0 & 0 & 2 & 1 & 5 & & & 3,6250 \\
\hline Total & 319 & 22 & 67 & 107 & 51 & 57 & 14 & 1 & 4,6865 \\
\hline \multicolumn{10}{|c|}{ Financléle beheersing (F), 201 cases } \\
\hline 5 beheersingsmaatregelen & 6 & & 2 & 3 & 1 & & & & 5,1667 \\
\hline 4. beheersingsmatregelen & 28. & 5 & 5 & 11 & 4 & 3 & & & 5,1786 \\
\hline 3 beheersingsmatregelen & 61 & 6 & 17 & 19 & 13 & 4 & 2 & & 5,0328 \\
\hline 2 beheersingsmatregelen & 65 & 3 & 14 & 22 & 10 & 12 & 3 & $\mathbb{1}$ & 4,5846 \\
\hline 1 beheensingsmaatregel & 34 & 2 & bi & 10 & 8 & 6 & 2 & & 4,5294 \\
\hline Geen beheersingsmatregel & 7 & & & 3 & 0 & 4 & & & 3,8571 \\
\hline Totaal & 201 & 16 & 44 & 68 & 36 & 29 & 7 & 1 & 4,7861 \\
\hline
\end{tabular}

Organisatorische beheersing ( 0 ), 189 cases

5 beheeningsmaatregellen

4 belleersingsmatregelen

7

3 beheersingsmatatregelen

$5,71.43$

$\begin{array}{llll}27 & 5 & 6 & 9\end{array}$

5,2963

2 behersingomatregelen

$63 \quad 4 \quad 20 \quad 21$

$$
61
$$

1242

1 beheeringsmatregel

Geen beheersingsmatuegel

\section{6}

Totanl

Informatiobehoersing (1), 63 cases

5 behersing romatregelen

4 beheorsingrimatreguelen

3. behexringsmatregelen

2 beheersingswatregelen

1 beheersing wratatregel

Coen behersingsmatregel

Totanl
63

$58 \quad 3 \quad 10 \quad 20$

4.5517

26

3

4,3214
189

$$
11
$$$$
1113
$$$$
3,33,3
$$

4,7884

$\begin{array}{llllllll}3 & & 2 & 1 & & & & 5,6667 \\ 11 & & 3 & 5 & 3 & & & 5,0000 \\ 19 & 2 & 2 & 9 & 2 & 3 & 1 & 4,7368 \\ 22 & 4 & 5 & 5 & 5 & 3 & & 5,0909 \\ 8 & & & 2 & 2 & & 4 & 3,2500\end{array}$




\section{Aantal soorten}

beheersingsmaatregelen

Prestatiebeheersing (E), 206 cases
5 beheersingsmaatregelen

4 beheersingsmaatregelen

3 beheersingsmatregelen

2 beheersingsmaatregen

1 beheersingsmaatregel

Geen beheersingsmaatregel

Totaal
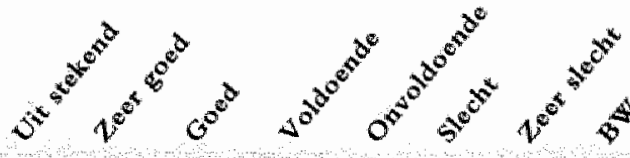

$\begin{array}{ccccccc}12 & 1 & 10 & 1 & & & \\ 27 & 5 & 8 & 6 & 4 & 3 & 1 \\ 52 & 4 & 17 & 18 & 5 & 6 & 2 \\ 69 & 5 & 20 & 18 & 11 & 12 & 3 \\ 41 & 2 & 10 & 5 & 9 & 10 & 5 \\ 5 & & & 2 & 1 & 2 & \\ 206 & 17 & 65 & 50 & 30 & 33 & 11\end{array}$

6,0000

5.1952

5,0385

4.7971

42683

4,0000

4,8544

\section{Geen voorkeur witgesproken, 38 cases}

5 beheersingmaatregelen

4 beheersingsmatregelen

3 behcersingmatregelen

2 beheersingsmantregelen

1 beheersingsmatregel

$\begin{array}{llllll}9 & 1 & 4 & 3 & & 1 \\ 12 & 1 & 3 & 4 & 2 & 1 \\ 9 & & 1 & 6 & 1 & \\ 8 & & 1 & 2 & 3 & 1\end{array}$

5,4444

4.8333

4,6667

4,1250

Geen beheersingsmaatregel

Totaal

$\begin{array}{llllll}9 & 15 & 6 & 3 & 3\end{array}$

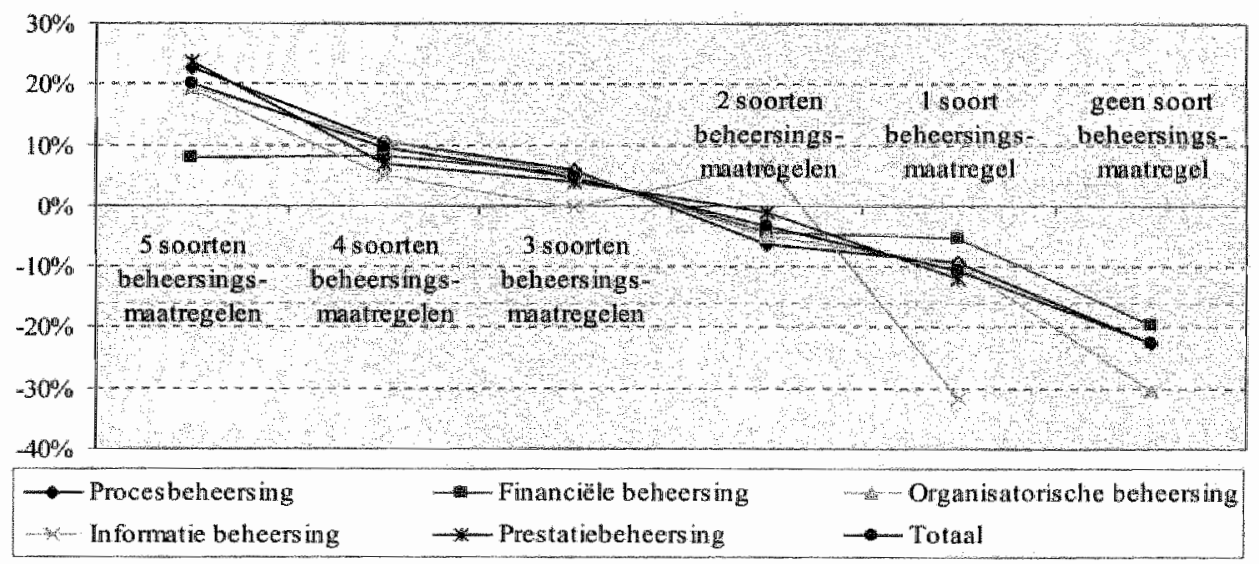

Procentuele verloop van de beoordelingswaarcen per subselectie "soort behearsingsmatregel op certe en tweede voorkeursplaats" ten opzichte van cle cotale beoondelingss wazde wan die selectie en de totale beootdelingswarde warn de totale populatie. 


\section{Bijlage 19: Verdeling waardeoordelen per MBTI type en beoordelingswaarden}

\section{Aantal soorten \\ beheersingsmatregelen}

9

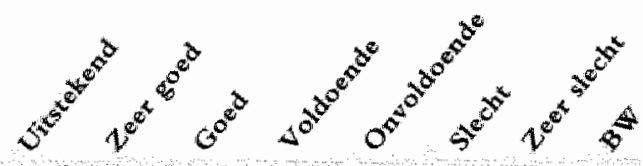

NP, 36 case, 12 accountants

5 beliedringsmatregen

4. befieversingsmatregelen

3 beheersingmantregelen

2 beheersingmantregelen

1 behyersingsiatratrel

Geen beheeringswatregel

Totanal

- NT, 170 cases, 59 accountants

5 behewingsmantregelen

4 bahexringsmatregelen

3 beheersingsmatregelen

2 beheersingsmatre gelen

1 beheersingsmatregel

Geen beheersingsmatrege:

Total

$-5 P-32$ cases 20 accountants

\begin{tabular}{|c|c|c|c|c|c|c|c|}
\hline 2 & & 1 & 1 & & & & 5,5000 \\
\hline 5 & & 3 & & 1 & & 1 & 4,8000 \\
\hline 13 & 1 & 3 & 6 & 2 & & 1 & 5,0000 \\
\hline 12 & & 2 & 5 & 4 & 1 & & 4,6667 \\
\hline 4 & & & 2 & 1 & 1 & & 42500 \\
\hline
\end{tabular}

5 beheersingsmatregelen

4 belweersingsmatregelen

3 behersingsmaatregelen

2 betsectingrinatiregelen

1 beheeningsmaatregel

Geen beheeringmatregell

Totan!

- $8 \mathrm{~T}-289$ cases, 108 accountants

5 behtersingsmantregen

4 behersingatratregelen

3 behearingmantrogelen

2 behearsingundatregelen

1 behersingsmatregel

Geer boherwingmatregel

Totial

$$
36
$$

36

1

$8 \quad 1$

204

49

58

29

6

170

9

14

2.2

4.8056

\begin{tabular}{|c|c|c|c|c|c|c|c|c|}
\hline 11 & 1 & 5 & 4 & 1 & & & & 5,5455 \\
\hline 50 & 8 & 11 & 19 & 8 & 4 & & & 5,2200 \\
\hline 81 & 9 & 21 & 29 & 13 & 7 & 2 & & 5,0741 \\
\hline 93 & 7 & 20 & 32 & 13 & 17 & 3 & 1 & 4,7204 \\
\hline 48 & 2 & 9 & 12 & 13 & 9 & 3 & & 4,4375 \\
\hline 6 & & & 3 & & 3 & & & 4,0000 \\
\hline 289 & 27 & 66 & 99 & 48 & 40 & 8 & 1 & 4,8754 \\
\hline
\end{tabular}




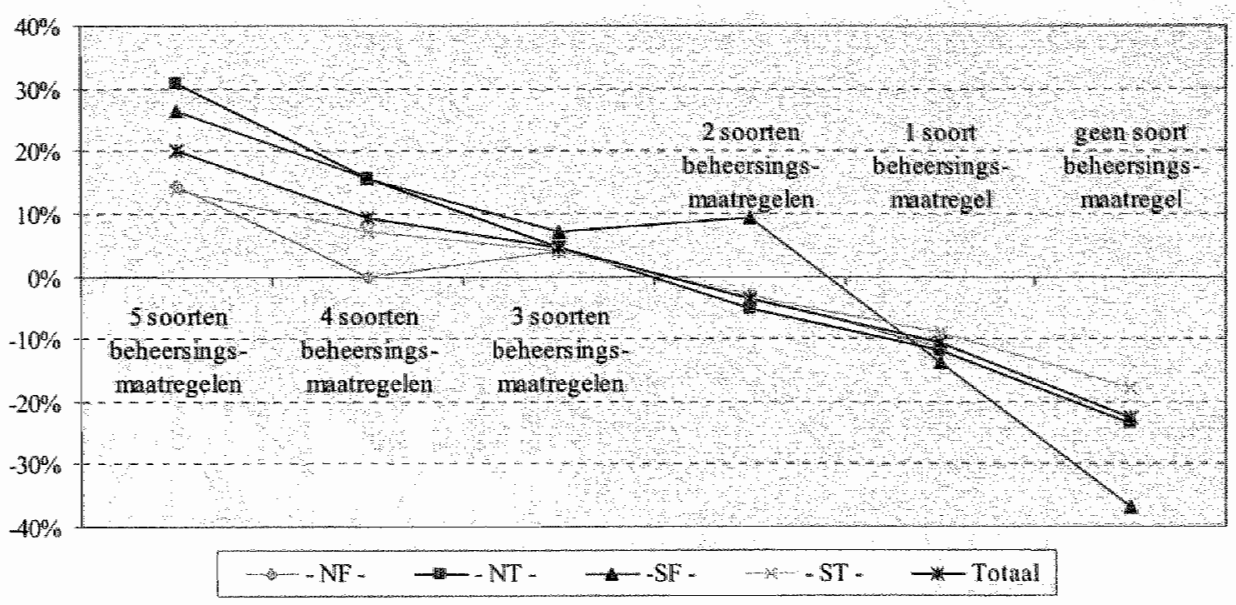

Procentuele verloop van de beoordelingswaarden per subselectie 'combinatie van waanemuing-index ens aordeelsvormingindex' ten opzichte van de totale beoordelingswarde van die selectie en de totale beoordelingswarcle van de totale populatie. 


\section{Bijlage 20: Verdeling waardeoordelen per Ambiguiteitwaarde en beoordelingswaarden}

Verdeling van de ambiguiteitwaarde, 199 accountants

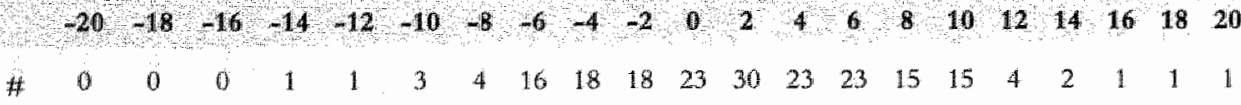

Aantal soorten

behoorsingsmaatregelen
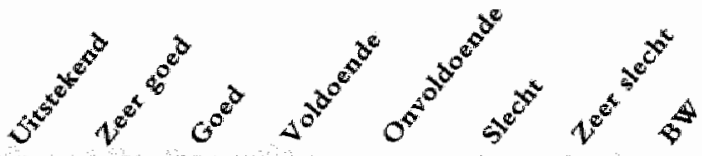

-1-20 tot en inet $-1-8,20$ cases, 9 accountants

5 behewringsmatregelen

6,0000

4 beheersingsmatregelen

3 bethersingswanatregelen

2 beheersingmatregelen

1 beheersingsinatregel

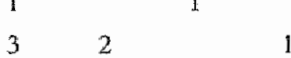

6,3333

51.3

5.2000

$\begin{array}{llll}7 & 1 & 2 & 2\end{array}$

5,0000

Geen beheersingmatregel

Totral

204

-16 6ot en net 0,210 eases, 75 accountants

5 beheersingsmatregelent

4 beheersingsmatregelen

3 beheersingsmatatriegelen

2 beheersingsmatregelen

1 beheersingsmaatregel

Geen belteersingsmatregel

\begin{tabular}{|c|c|c|c|c|c|c|c|c|}
\hline 6 & & 6 & & & & & & 6,0000 \\
\hline 33 & 3 & 9 & 12 & 4 & 4 & 1 & & 5,0000 \\
\hline 67 & 4 & 21 & 24 & 1 & 4 & 3 & & 5,0149 \\
\hline 67 & 7 & 15 & 21 & 10 & 11 & 2 & 1 & 4,8060 \\
\hline 33 & 1 & 4 & 6 & 11 & 8 & 3 & & 4,0909 \\
\hline 4 & & & 1 & & 3 & & & 3,5000 \\
\hline 210 & 15 & 55 & 64 & 36 & 30 & 9 & 1 & 4,8000 \\
\hline
\end{tabular}

"Totatal

2 lot on met 6,209 cases, 76 accountants

5 behersingmatregelen

$$
1
$$

4 behesringsmatregelen

3 boheersingsmatuegelen

2 beheersingmatregelen

1 beheersingmautregel

$\begin{array}{cccc}11 & 1 & 5 & 4 \\ 30 & 5 & 6 & 11 \\ 59 & 7 & 15 & 18 \\ 62 & 1 & 13 & 21 \\ 40 & 2 & 7 & 13 \\ 7 & & & 3 \\ 209 & 16 & 46 & 70\end{array}$

Geen behersingsmatregel

\section{ocinatants}

5 tot on met 20,88 cas

4 beheersingsmatregelen

3 behexsingsmatregelen

2 bethersingmaatregelen.

1 beheersingsmatrege]

Geen beheersingsmaatregel

Total

$\begin{array}{cccc}4 & 1 & 1 & 2 \\ 11 & 2 & 6 & 1 \\ 24 & 1 & 6 & 9 \\ 32 & & 4 & 13 \\ 15 & 1 & & 5 \\ 2 & & & \\ 88 & 5 & 17 & 30\end{array}$

$\begin{array}{cccc}2 & & & \\ 1 & & 2 & \\ 9 & 4 & 3 & 1 \\ 13 & 6 & 5 & 4 \\ 5 & 4 & 5 & \\ & & 2 & \\ 30 & 14 & 17 & 5\end{array}$

5,5455

5,2333

5,0909

4.5161

4.3750

4,0000

4,7656

5.7500

5.5455

4,7917

4.2500

4,2000

3,0000

4,5909 


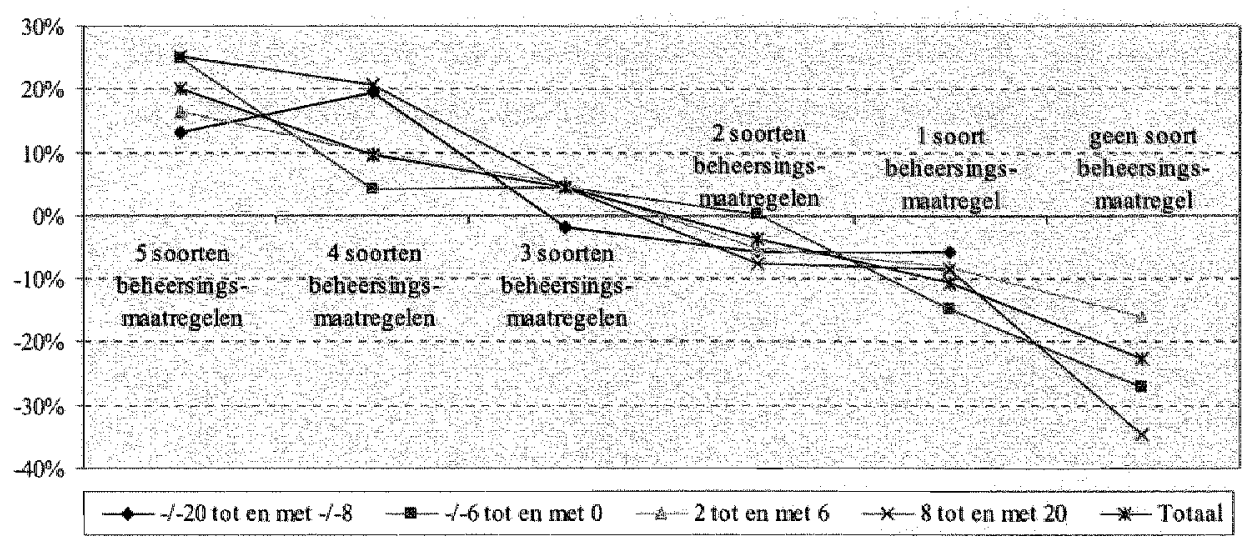

Procentuele verloop van de beoordelingswarden per subselectie 'ambiguiteitsgroep' ten opzichte wan de totale beoordelingswaarde van die selectie en de totale beoordelingswaarde van de totale populatie. 


\section{Bijlage 21: Verdeling waardeoordelen per mate van weerspiegeling en beoordelingswaarden}

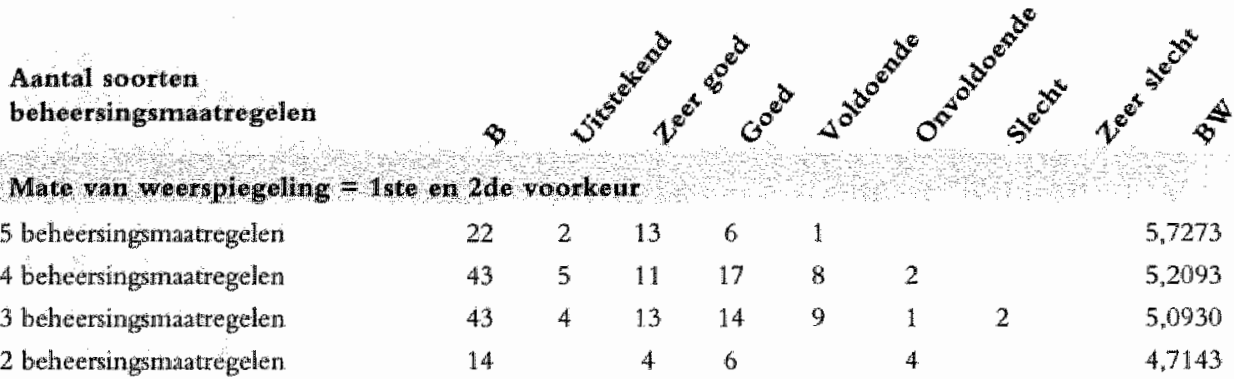

1 beheersingsmatregel

Komen hier niet woor

Geen beheersingsmaatregel

Komen hier niet voor

Totaal 12

$22 \quad 11$

$41 \quad 43$

18

7

5,2049

Mate ran we erspiegelling $=1$ ste of 2 de yoonkevir

5 beheersingsmatregelen

4 beheersingsmatregelen

3 beheersingsmaratregelen

2 beheersingstabatregelen

1 beheersingsmaatregel

Geen beheersingsmantegel

Total
Komen hier niet woor

\begin{tabular}{|c|c|c|c|c|c|c|c|c|}
\hline 25 & 6 & 6 & 5 & 3 & 4 & 1 & & 5,1600 \\
\hline 85 & 8 & 21 & 30 & 1.4 & 11 & 1 & & 4,9765 \\
\hline 94 & 6 & 19 & 32 & 16 & 15 & 5 & 1 & 4,6383 \\
\hline 28 & 1 & 4 & 7 & 10 & 3 & 3 & & 4,3214 \\
\hline
\end{tabular}

Komen hier riet woor

$\begin{array}{lllllllll}232 & 21 & 50 & 74 & 43 & 33 & 10 & 1 & 4,7802\end{array}$

Mate ran weerspiegeling = geen voorkeur

5 beheemingsmatregelen

4 beheersingsmatregelen

3 behearsingsinatregelen

2 beheresings matregelen

1 behereringsmatregel

Geen belyersingsmatregel

Totaal
Komen hiver niet voor

$\begin{array}{cccccccc}9 & 1 & 4 & 3 & & 1 & & 5,4444 \\ 27 & 1 & 8 & 10 & 3 & 3 & 2 & 4,8148 \\ 60 & 3 & 11 & 19 & 12 & 11 & 4 & 4,5167 \\ 64 & 2 & 10 & 18 & 11 & 17 & 6 & 4,2344 \\ 13 & & & 4 & 1 & 8 & & 3,6923 \\ 173 & 7 & 33 & 54 & 27 & 40 & 12 & 4,4451\end{array}$




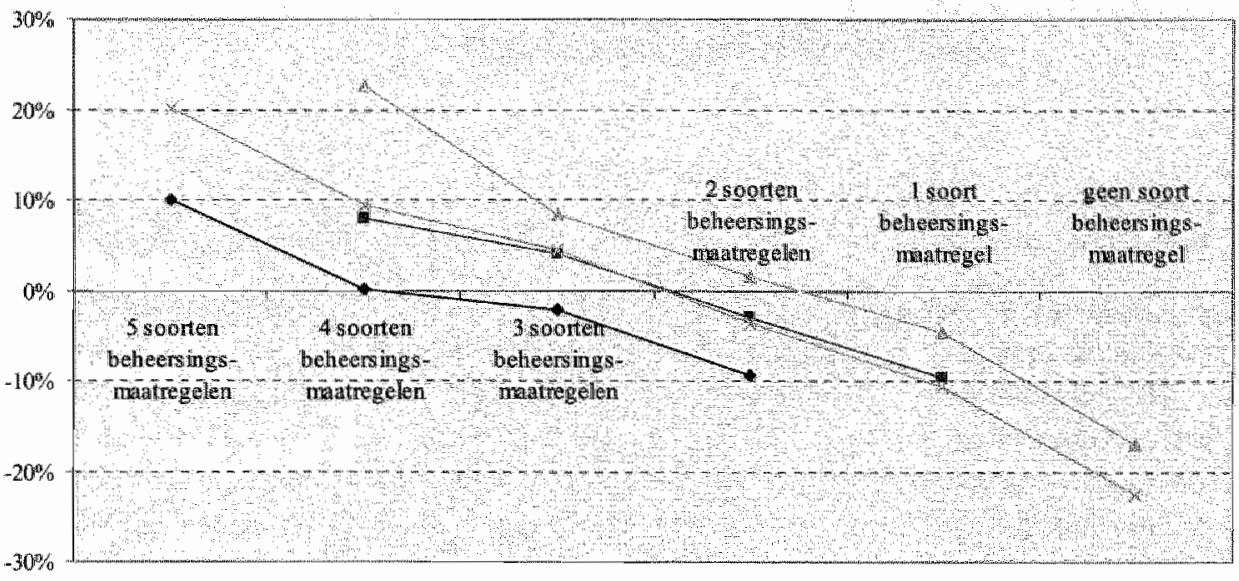

- Mate van weers piegeling $=0-$ Mate wan weerspiegeling $=1-$ Mate van weerspiegelling $=2-$, Total

Procentuele verloop van de beoordelingswaarden per subselectie 'mate van weerspiegeling' ten opzichte van de totale beoordelingswatarde van die selectie en de totale beoordelingswarde van de totale populatie. 


\section{Bijlage 22: Verdeling waardeoordelen conform voorkeur en beoordelingswaarden}

\begin{tabular}{|c|c|c|c|c|c|c|c|c|c|}
\hline \multicolumn{10}{|l|}{$\begin{array}{l}\text { Aantal soorten } \\
\text { beherersingsmaatregelen }\end{array}$} \\
\hline \multicolumn{10}{|c|}{ Procesbeheorsing (P), 152 cases } \\
\hline 5 beheeringsmatregelen & 16 & 2 & 9 & 4 & 1 & & & & 5,7500 \\
\hline 4 beheersingsmatregelen & 34 & 5 & 8 & 11 & 5 & 4 & 1 & & 5,0588 \\
\hline 3 beheersingsmaatregrelen & 57 & 7 & 12 & 22 & 9 & 7 & & & 5,0526 \\
\hline 2 beheersingsmatregelen & 36 & 2 & 6 & 13 & 6 & 6 & 3 & & 4,5278 \\
\hline 1 beheersingsmatregel & 9 & & 2 & 3 & 3 & & 1 & & 4,5556 \\
\hline Geen belieersingsmatreged & \multicolumn{9}{|c|}{ Konnen hier niet woor } \\
\hline Totaal & 152 & 16 & 37 & 53 & 24 & 17 & 5 & & 4,9737 \\
\hline \multicolumn{10}{|c|}{ Financiale bohnersing ( $F$ ), 99 cases } \\
\hline 5 beheersingsmaatregelen & 6 & & 2 & 3 & 1 & & & & 5,1667 \\
\hline 4 belnetsingsmatregelen & 24 & 4 & 4 & 11 & 3 & 2 & & & 5,2083 \\
\hline 3 beheersingsmatregelen & 32 & 3 & 9 & 8 & 8 & 2 & 2 & & 4,9063 \\
\hline 2 beheersingsnatregelen & 30 & & 5 & 116 & 1. & 7 & & 1 & 4.5333 \\
\hline 1 beheersingsnaatregel & 7 & & & 2 & 3 & 1 & 1 & & 3,8571 \\
\hline Geen beheersingsmatregel & \multicolumn{9}{|c|}{ Komen hier niet voor } \\
\hline Totaal & 99 & 7 & 20 & 40 & 16 & 12 & 3 & 1 & 4,8081 \\
\hline \multicolumn{10}{|c|}{ Organisatorische heheersing $(0), 95$ cases } \\
\hline 5 beheersingsmaatregelen & 7 & 1 & 3 & 3 & & & & & 5,7143 \\
\hline 4 beheersingsmatregelen & 24 & 5 & 6 & 8 & 5 & & & & 5.4583 \\
\hline 3 beheersingsmatregelen & 38 & 1 & 15 & 11 & 9 & 1 & 1 & & 5.0789 \\
\hline 2 beherersingentaatregeley & 21 & 2 & 4 & 7 & 5 & 2 & $\mathbb{1}$ & & 4,8095 \\
\hline 1 butheersingymantregel & 5 & & 1 & 2 & 2 & & & & 4,8000 \\
\hline Geen belweersingsmatregel & \multicolumn{9}{|c|}{ Kornen bier nuet voor } \\
\hline Totaral & 95 & 9 & 29 & 31 & 21 & 3 & 2 & & 5,14474 \\
\hline \multicolumn{10}{|c|}{ Informativeboheersing ( $), 36$ cases } \\
\hline 5 beheersingstmatregelen & 3 & & 2 & 1 & & & & & 5,6667 \\
\hline 4 betreesingsmatregelen & 9 & & 2 & 5 & 2 & & & & 5,0000 \\
\hline 3 beheeringmaatregelen. & 1.3 & 2 & 1 & 7 & 1 & 1 & 1 & & 4,9231 \\
\hline 2 beheersingsnaatregelen & 10 & 1 & 3 & 3 & 1 & 2 & & & 5,0000 \\
\hline 1 beheersingsmatregel & $\mathbb{1}$ & & & & & & 1 & & 2,0000 \\
\hline
\end{tabular}

Totaal

$36 \quad 3 \quad 8$

1643

4,9444 
Aantal soorten

beheersingsmaatregelen

Prestatiebeheersing (E), 94 cases

5 beheersingmaatregelen

4 beheersingsmaatregelen

3 betheersingsmaatregelen

2 beheerkingsmaatregelen

1 beheersingsmaatregel

Geen behersingsmaatregel

Totaal

$\$$
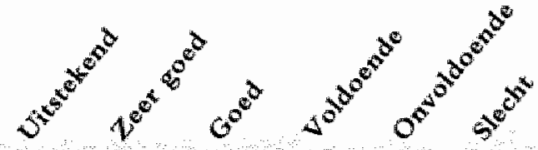

$4^{2}$

12

20

20

3

2

25

$\begin{array}{lll}6 & 1 & 1\end{array}$

Komen hier niet voor

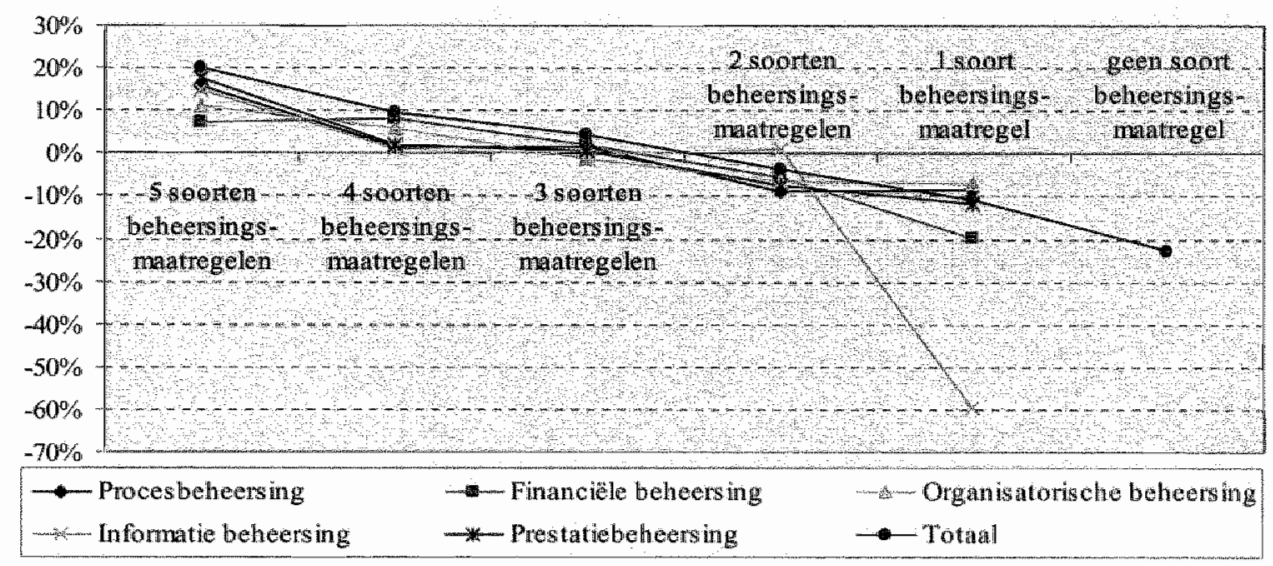

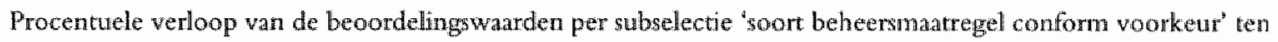
opzichte wan de totale beoordelingswarde van die selectie en de totale beoordelingswarde van de totale populatie. 


\section{Bijlage 23: Verdeling waardeoordelen zonder voorkeur en beoordelingswaarden}

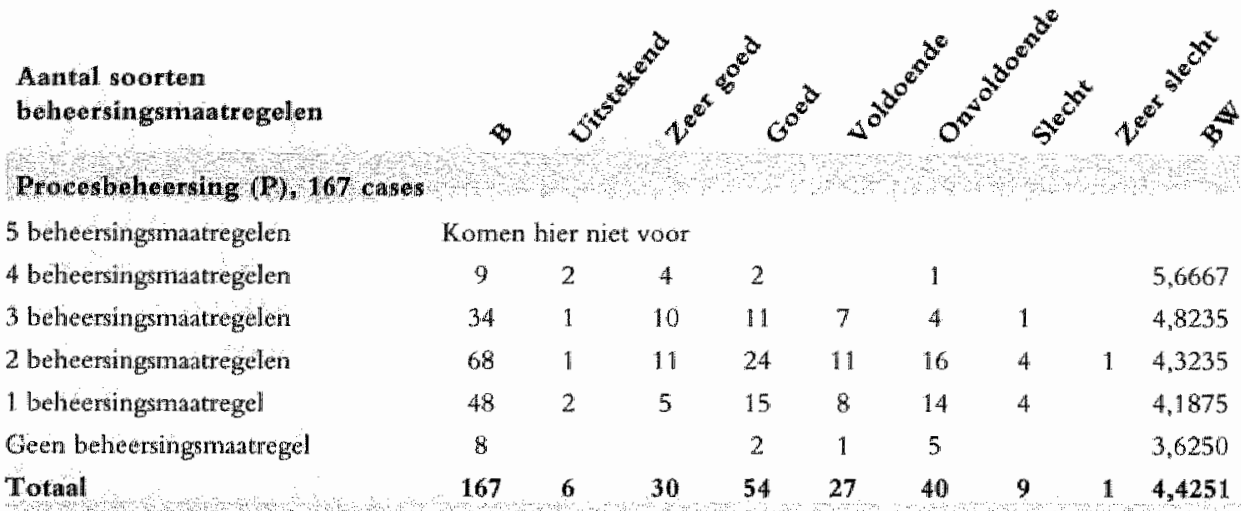

Financiele beheersing (P), 102 cases

5 beheersingsmatregelen

Komen hier net voor

4 belweersingsmatregeten

4. 1

3 belweersingsmatregelen

2 beheersingsinatregelen

1 beheersingsinaatregel

Geen beheersingsmatregel

$29 \quad 3$

$35 \quad 3$

$27 \quad 2 \quad 6$

7

Totaall 102

24

Organisatorisohe beheersing (O), 94 cases

5 beheersingsmatregelen

4 beheersingmatregelen

Komen hier niet voor

3 beheersingsmaatregelen

2 beheersingsmatregelen

1 beheersingsinaterel

3

3

$25 \quad 3 \quad 5$

$37 \quad 1$

23

61

1

5,0000

11: 52

5.1724

Geen behersingunatregel

94

Totanal.

Juformatiebehewing (1), 27 cases

5 bethersingmatregelen

4 beheersingamaatregelen

3 beheensingsmantregelen

2 betheersingsmatregelen

1 betreersingsinatregel

Geen behereringsmatregel

Totanal

27

Komen hier niet yoor

$\begin{array}{llllllll}2 & & 1 & & 1 & & & 5,0000 \\ 6 & & 1 & 2 & 1 & 2 & & 4,3333 \\ 12 & 3 & 2 & 2 & 4 & 1 & & 5,1667 \\ 7 & & & 2 & 2 & & 3 & 3,4286\end{array}$

4,6286

4,7037

3,8571

4,7647

$\begin{array}{llllll}3 & 4 & 6 & 8 & 3 & 3\end{array}$

4,5185 
Aantall soorten

beheersingsmaatregelen

Prestatiebeheersing (E), 112 cases

5 beheersingsmaatregelen

4 beheersingsmatregelen

3 beheersingsmatregelen

2 beheersingsmatregelen

1 beheersingsmatregel

Geen beheersingsmatregel

Total

Geen voorkeur nitgesproken, 38 cases

5 beheersingsmatregelen

4 beheersingsmatregelen

3 beheersingsmatregeler

2 beheersingsmatregeler

1 beheersingsmatrigel

Geen beheersingsmatregel

Totaal $\vartheta$
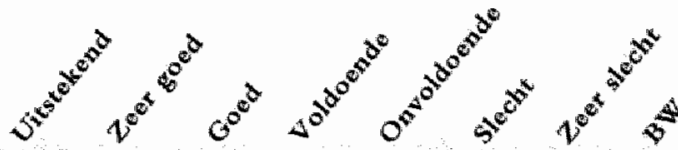

Komen bier niet yoor

\begin{tabular}{|c|c|c|c|c|c|c|c|}
\hline 7 & 3 & & 2 & & 1 & 1 & 5,1429 \\
\hline 21 & 1 & 7 & 8 & & 4 & 1 & 4,9048 \\
\hline 44 & 4 & 11 & 13 & 8 & 6 & 2 & 4,8409 \\
\hline 35 & 1 & 9 & 5 & 7 & 8 & 5 & 4,2286 \\
\hline 5 & & & 2 & 1 & 2 & & 4,0000 \\
\hline 112 & 9 & 27 & 30 & 16 & 21 & 9 & 4,6420 \\
\hline
\end{tabular}

Komen bier niet voor

\begin{tabular}{|c|c|c|c|c|c|c|c|}
\hline 9 & 1 & 4 & 3 & & 1 & & 5,4444 \\
\hline 12 & 1 & 3 & 4 & 2 & 1 & 1 & 4,8333 \\
\hline 9 & & 1 & 6 & 1 & & 1 & 4,6667 \\
\hline 8 & & 1 & 2 & $3=$ & 1 & 1 & 4,1250 \\
\hline
\end{tabular}

Procentuele verloop van de beoordelingswarden per subselecue "soort beheersmatregel zonder voorkeur" ten opzichte wan de totale beoordelings warde van die sejecte en de totale beoordelingswarde van de totale populatic. 


\section{Bijlage 24: MBTI indicatoren van 143 accountants volgens CAP'T}

IN TOTAAL

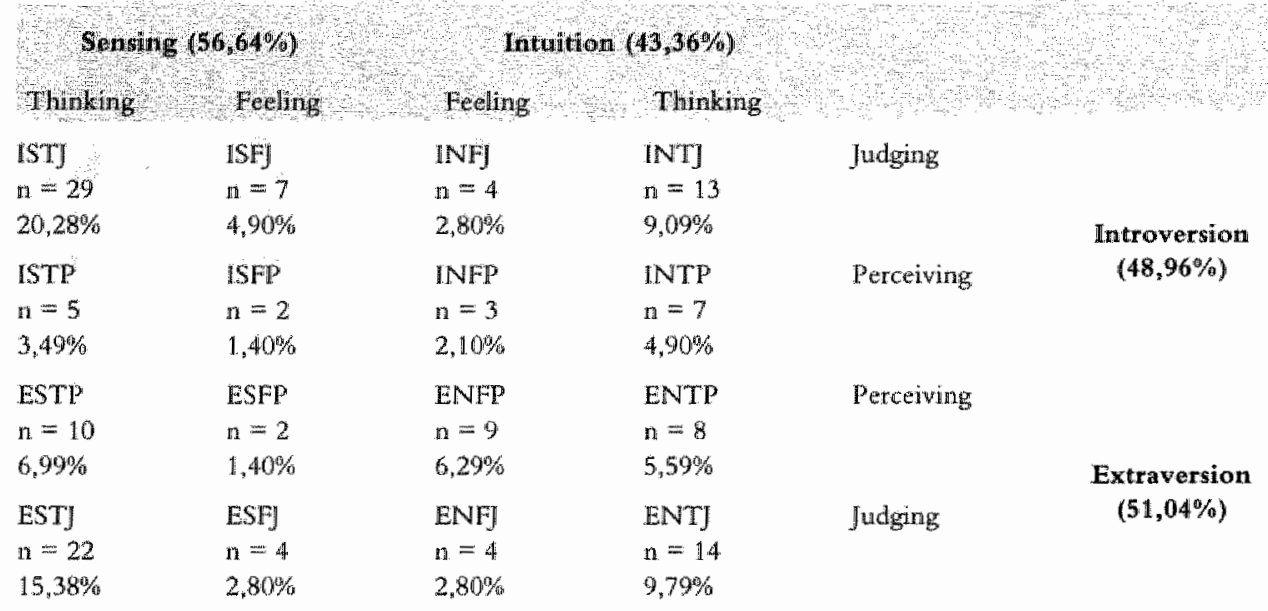

IN DETAIL

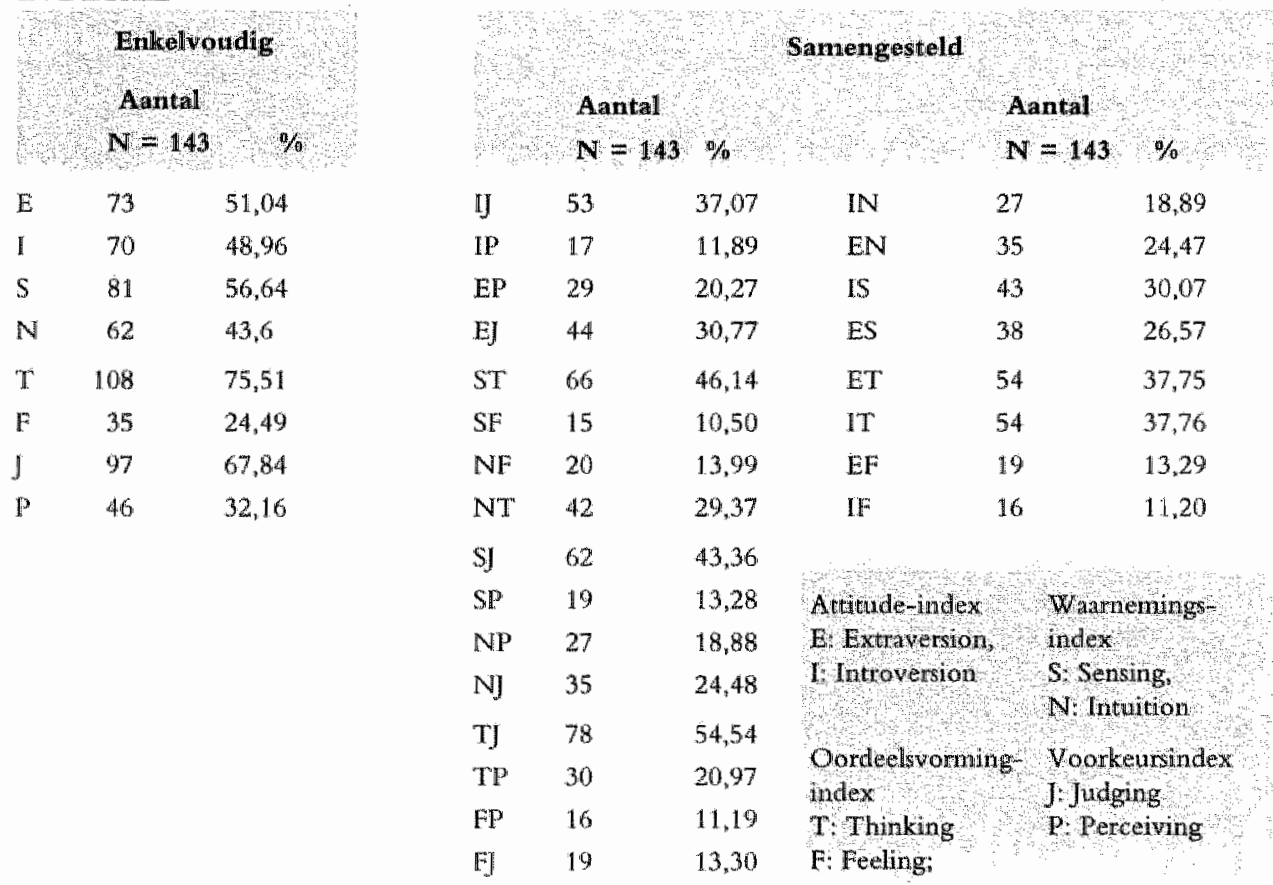


Onderstaand is per index aangegeven wat de betekenis is van ieder indicator is, warbij tevens is aangegeven met welk percentage deze indicator de accountants beschrijft.

\section{Attitude-index}

Extraversion types, waartoe $51,04 \%$ van de accountants behoren, werken het liefst interactief met mensen dan wel in activiteiten welke buiten de directe werkplek liggen en zijn gericht op mensen en objecten.

Introversion types, waartoe $48,96 \%$ van de accountants behoren, werken het liefst alleen en in situaties waar tijd en ruimte gegeven wordt aan concentratie en zijn gericht op concepten en ideeën.

\section{Waamemingsindex}

Sensing types, waartoe $56,64 \%$ van de accountants behoren, hebben een voorkeur voor werk dat aandacht vraagt voor detail en zorgvuldige waarneming van feiten en gebeurtenissen met behulp van de vijf zintuigen.

Intuition types, waartoe $43,36 \%$ van de accountants behoren, hebben een voorkeur voor werk dat aandacht vraagt voor het oplossen van nieuwe problemen.

\section{Oordeelsvormingindex}

Thinking types, waartoe $75,51 \%$ van de accountants behoren, prefereren het werk dat een logische volgorde in de verwerking vraagt zoals het werken met getallen en fysieke objecten waarbij het oordeelsvormingproces als onpersoonlijk en op logica is gebaseerd.

Feeling types, waartoe $24,49 \%$ van de accountants behoren, prefereren het werk waarbij service verleend wordt aan mensen binnen een harmonieuze en waarderingsvolle omgeving.

\section{Voorkeursindex}

Judging types, waartoe $67,84 \%$ van de accountants behoren, komen het best tot hun recht in werksituaties waarbij de nadruk ligt op de behoefte aan systematiek.

Perceiving types, waartoe $32,16 \%$ van de accountants behoren, komen het best tot hun recht in werksituaties waarbij de nadruk ligt op het kunnen omgaan met zich veranderende situaties, of waar het begrijpen van situaties belangrijker is dan het managen ervan. 


\section{Bijlage 25: MBTI indicatoren van 143 accountants en 89 consultants volgens CAPT}

IN TOTAAL

\begin{tabular}{|c|c|c|c|c|c|}
\hline $\begin{array}{l}\text { Sensing } \\
\text { Acc. } 56,64 \%\end{array}$ & Con. 39,31\% & $\begin{array}{l}\text { Intuition } \\
\text { Ace, } 43,36 \%\end{array}$ & Con: $60,69 \%$ & & \\
\hline Thinking & reeling & Feling & Thinking & & 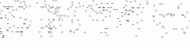 \\
\hline IST] & $\mathrm{ISFJ}$ & INF & INTJ & Judging & \\
\hline Acc:: $20,28 \%$ & Acc. $4,90 \%$ & Acc: $2,80 \%$ & Acc: $9,09 \%$ & & Introversion \\
\hline Con ..: $13,45 \%$ & Con: $4,49 \%$ & Con.: $6,74 \%$ & Conn.: $7,87 \%$ & & Acc.: $48,96 \%$ \\
\hline ISTP & ISFP & INFP & WNTP & Perceiving & Conn: $48,29 \%$ \\
\hline Acc: $3,49 \%$ & Acc.: $1.40 \%$ & $A c c:=2,10 \%$ & Ace: $4,90 \%$ & & \\
\hline Con.: $3,37 \%$ & Con: $2,25 \%$ & Con.: $7,87 \%$ & Con.: $2,25 \%$ & & \\
\hline ESTP & ESFP & ENFP & ENTP & Perceiving & \\
\hline Acc.: $6,99 \%$ & Acc.: $1,40 \%$ & Acc.: $6,29 \%$ & Acc. $5,59 \%$ & & Extraversion \\
\hline Con.: 0,00\% & Con $: 0,00 \%$ & Con.: $12,36 \%$ & Conn: $7,87 \%$ & & Acc. $51,04 \%$ \\
\hline ESTI & ESFJ & ENFJ & ENTJJ & Judging & Con.: $51,71 \%$ \\
\hline Acc.: $15,38 \%$ & Acc: $: 2,80 \%$ & Acc.: $2,80 \%$ & Acc: $9,79 \%$ & & \\
\hline Con: $11,26 \%$ & Con.: $4.49 \%$ & Con: $6,74 \%$ & Con.: $8,99 \%$ & & \\
\hline
\end{tabular}

IN DETAIL

Enkelvouditg in \%

Samengesteld in \%

\begin{tabular}{|c|c|c|c|c|c|c|c|c|}
\hline $\begin{array}{c}\text { Accountants } \\
N=143\end{array}$ & $\begin{array}{c}\text { Consultants } \\
\mathrm{N}=89\end{array}$ & 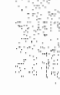 & $\begin{array}{c}\text { Accountants } \\
\mathrm{N}=143\end{array}$ & $\begin{aligned} & \text { Consultant } \\
& \mathrm{N}=89\end{aligned}$ & & $\begin{array}{l}\text { Accounte } \\
\mathrm{N}=14\end{array}$ & & $\begin{array}{c}\text { Consultants } \\
\mathrm{N}=89\end{array}$ \\
\hline 51,044 & 51,71 & II & 37,07 & 32,55 & $\mathbb{I N}$ & 1889 & & 24,73 \\
\hline 48,96 & 48,29 & IP & 11,89 & 15,74 & EN & 24,47 & & 35,96 \\
\hline 56,64 & 39,31 & $\mathbb{E P}$ & 20,27 & 20,23 & IS & 30,07 & & 23,56 \\
\hline 43,36 & 60,69 & EI & 30,77 & 31,48 & ES & 26,57 & & 15,75 \\
\hline 75,51 & 55,06 & $\mathrm{sT}$ & 46,114 & 28,08 & $\mathrm{ET}$ & 37,75 & & 28,12 \\
\hline 24,49 & 44,94 & $\mathrm{SF}$ & 10,50 & 11.23 & IT & 37,76 & & 26,94 \\
\hline 67,84 & 64,03 & $\mathrm{NF}$ & 13,99 & 33,71 & $\mathrm{EF}$ & 13,29 & & 23,59 \\
\hline 32,16 & 35,97 & $\mathrm{NT}$ & 29,37 & 26,98 & $\mathbb{I E}$ & 11,20 & & 21,35 \\
\hline & & $\mathrm{s}$ & 43,36 & 33,69 & & & & \\
\hline & & $\mathrm{SP}^{\mathrm{B}}$ & 13,28 & 5,62 & \multirow{3}{*}{\multicolumn{2}{|c|}{$\begin{array}{l}\text { Attitude-inder, } \\
\text { E. Extraversion } \\
\text { 1/ Introversion }\end{array}$}} & \multirow{2}{*}{\multicolumn{2}{|c|}{$\begin{array}{l}\text { Waarnenungs } \\
\text { index }\end{array}$}} \\
\hline & & $N P$ & 18,88 & 30,35 & & & & \\
\hline & & N) & 24.48 & 30,34 & & & \multirow{2}{*}{\multicolumn{2}{|c|}{$\begin{array}{l}\text { S. Sersing } \\
\text { N. Intuition }\end{array}$}} \\
\hline & & TJ & 54,54 & 41,57 & & & \\
\hline & & $\mathrm{TP}$ & 20.97 & 13.49 & \multirow{3}{*}{\multicolumn{2}{|c|}{$\begin{array}{l}\text { Oondeelsvorming } \\
\text { index, } \\
\text { T Thinking } \\
\text { F: Feeling }\end{array}$}} & \multirow{3}{*}{\multicolumn{2}{|c|}{$\begin{array}{l}\text { Voorkeursindex } \\
\text { J Judging } \\
\text { P. Percerving }\end{array}$}} \\
\hline & & $\mathrm{FP}$ & 11,19 & 22,48 & & & & \\
\hline & & $\mathrm{B}$ & 13,30 & 22,46 & & & & \\
\hline
\end{tabular}




\section{Bijlage 26: MBTI uitkomsten van 1181 accountants volgens diverse onderzoeken}

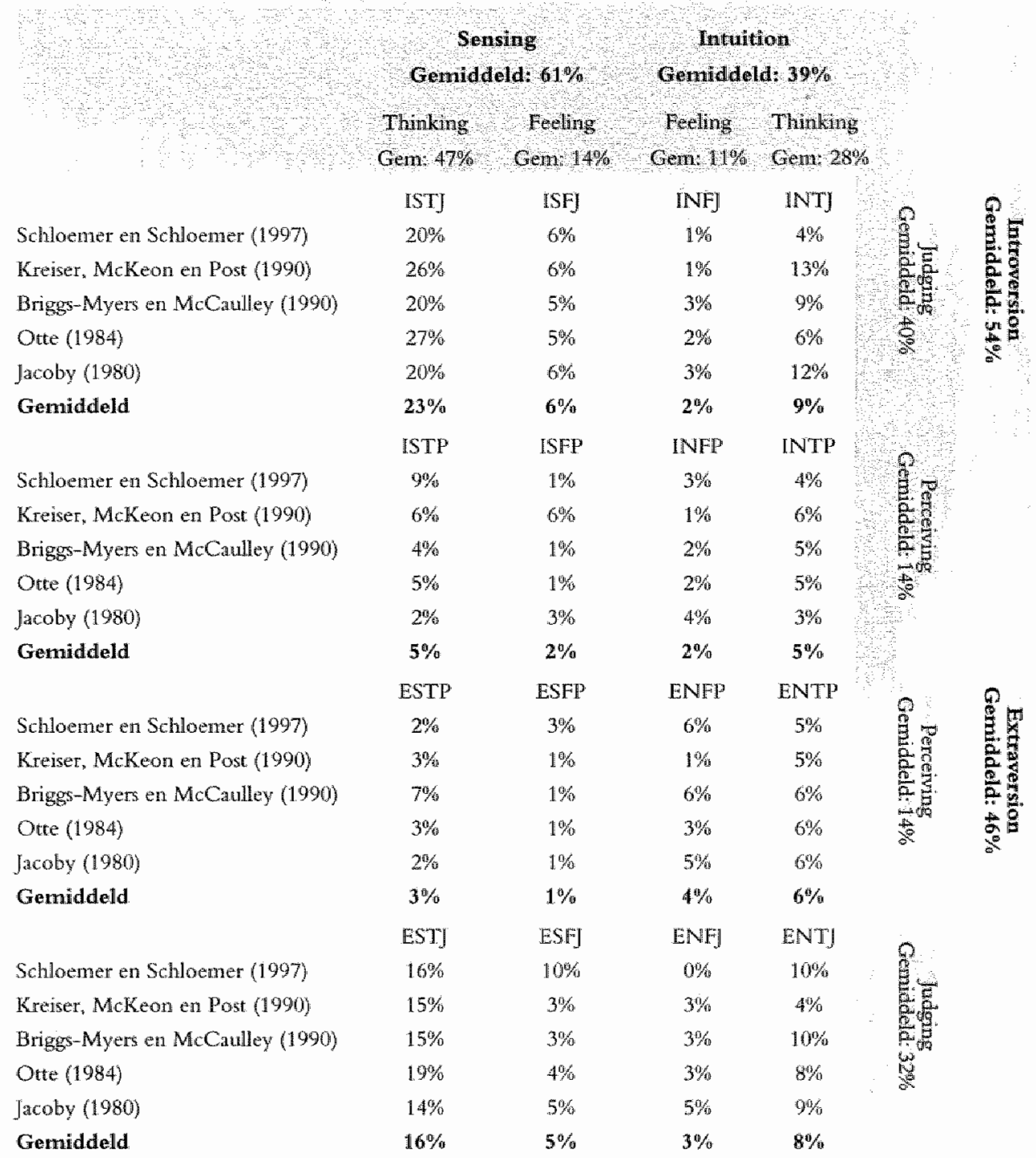




\section{Bijlage 27: MBTI indicatoren van 199 accountants volgens huidig onderzoek}

IN TOTAAL

\begin{tabular}{|c|c|c|c|c|c|}
\hline Thinking & reling & Feling & Thinking & & \multirow[b]{2}{*}{$\begin{array}{c}\text { Introversion } \\
\left(42,71^{10} \%\right)\end{array}$} \\
\hline $\begin{array}{l}\text { [ST] } \\
n=39 \\
19,60 \%\end{array}$ & $\begin{array}{l}\text { ISFJ } \\
n=6 \\
3.01 \%\end{array}$ & $\begin{array}{l}\text { INFJ } \\
n=1 \\
0,50 \%\end{array}$ & $\begin{array}{l}\text { INT] } \\
n=9 \\
4,52 \%\end{array}$ & Judging & \\
\hline $\begin{array}{l}\text { ISTP } \\
\mathrm{n}=13 \\
6,54 \%\end{array}$ & $\begin{array}{l}15 F P \\
n=6 \\
3,01 \%\end{array}$ & $\begin{array}{l}\text { INFP } \\
n=1 \\
0,50 \%\end{array}$ & $\begin{array}{l}\text { INTP } \\
\mathrm{n}=10 \\
5,03 \%\end{array}$ & Perceiving & \\
\hline $\begin{array}{l}\text { ESTP } \\
n=14 \\
7,04 \%\end{array}$ & $\begin{array}{l}\text { ESFP } \\
n=2 \\
1,01 \%\end{array}$ & $\begin{array}{l}\text { ENFP } \\
n=6 \\
3,01 \%\end{array}$ & $\begin{array}{l}\text { ENTP } \\
n=20 \\
10,05 \%\end{array}$ & Perceiving & $\begin{array}{l}\text { Extraversion } \\
(57,29 \%)\end{array}$ \\
\hline $\begin{array}{l}\text { EST] } \\
\mathrm{n}=42 \\
21,11 \%\end{array}$ & $\begin{array}{l}\text { ESFI } \\
n=6 \\
3,01 \%\end{array}$ & $\begin{array}{l}\mathrm{ENFJ} \\
\mathrm{n}=4 \\
2,01 \%\end{array}$ & $\begin{array}{l}\text { ENTJ } \\
\mathrm{n}=20 \\
10,05 \%\end{array}$ & Judging & \\
\hline
\end{tabular}

IN DETAIL

Enkelvoudig

\section{Aantal $\% \%$}

199

$\begin{array}{lrr}\mathrm{E} & 114 & 57,29 \\ \mathrm{I} & 85 & 42,71 \\ \mathrm{~S} & 128 & 64,33 \\ \mathrm{~N} & 71 & 35,67 \\ \mathrm{~T} & 128 & 83,94 \\ \mathrm{~F} & 71 & 16,06 \\ \mathrm{~J} & 127 & 63,81 \\ \mathrm{P} & 72 & 36,19\end{array}$

\begin{tabular}{|c|c|c|c|c|c|}
\hline & & & anengesteld & & \\
\hline & $\begin{array}{c}\text { Aantal } \\
199\end{array}$ & $\%$ & & $\begin{array}{c}\text { Aantal } \\
199\end{array}$ & $\%$ \\
\hline IJ & 55 & 27,643 & IN & 21 & 10,55 \\
\hline IP & 30 & 15,08 & EN & 50 & $25_{x} 12$ \\
\hline $\mathrm{EP}$ & 42 & 21,11 & $\mathbb{I S}$ & 64 & 32,16 \\
\hline $\mathbb{E J}$ & 72 & 36.18 & $\mathrm{ES}$ & 64 & 32,17 \\
\hline $\mathrm{ST}$ & 108 & 54,29 & ET & 96 & 48,25 \\
\hline $\mathrm{SF}$ & 20 & 10,04 & $r \mathrm{~T}$ & 71 & 35,69 \\
\hline NF & 12 & 6,02 & $\mathrm{EF}$ & 18 & 9,04 \\
\hline $\mathrm{NT}$ & 59 & 29,65 & $\mathbb{I F}^{2}$ & 14 & 7,02 \\
\hline S] & 93 & 46,73 & & & \\
\hline $\mathrm{SP}^{\mathrm{H}}$ & 35 & 17,60 & Attitud-1ndles & & sings- \\
\hline NP & 37 & 18,59 & E. Extrayersion & Ind & \\
\hline NJ & 34 & 17,08 & I Introversion & & \\
\hline T] & 110 & 55,28 & & & \\
\hline $\mathrm{TP}$ & 57 & 28,66 & $\begin{array}{l}\text { Oorde elsvor- } \\
\text { mingindex }\end{array}$ & & irsinidex \\
\hline $\mathrm{FP}$ & 15 & 7,53 & T) Thinking & & iving \\
\hline $\mathrm{FI}$ & 17 & 8,53 & Feeling & & \\
\hline
\end{tabular}




\section{Bijlage 28: MBTI indicatoren huidig onderzoek versus CAPT en overige onderzoeken}

IN TOTAAL

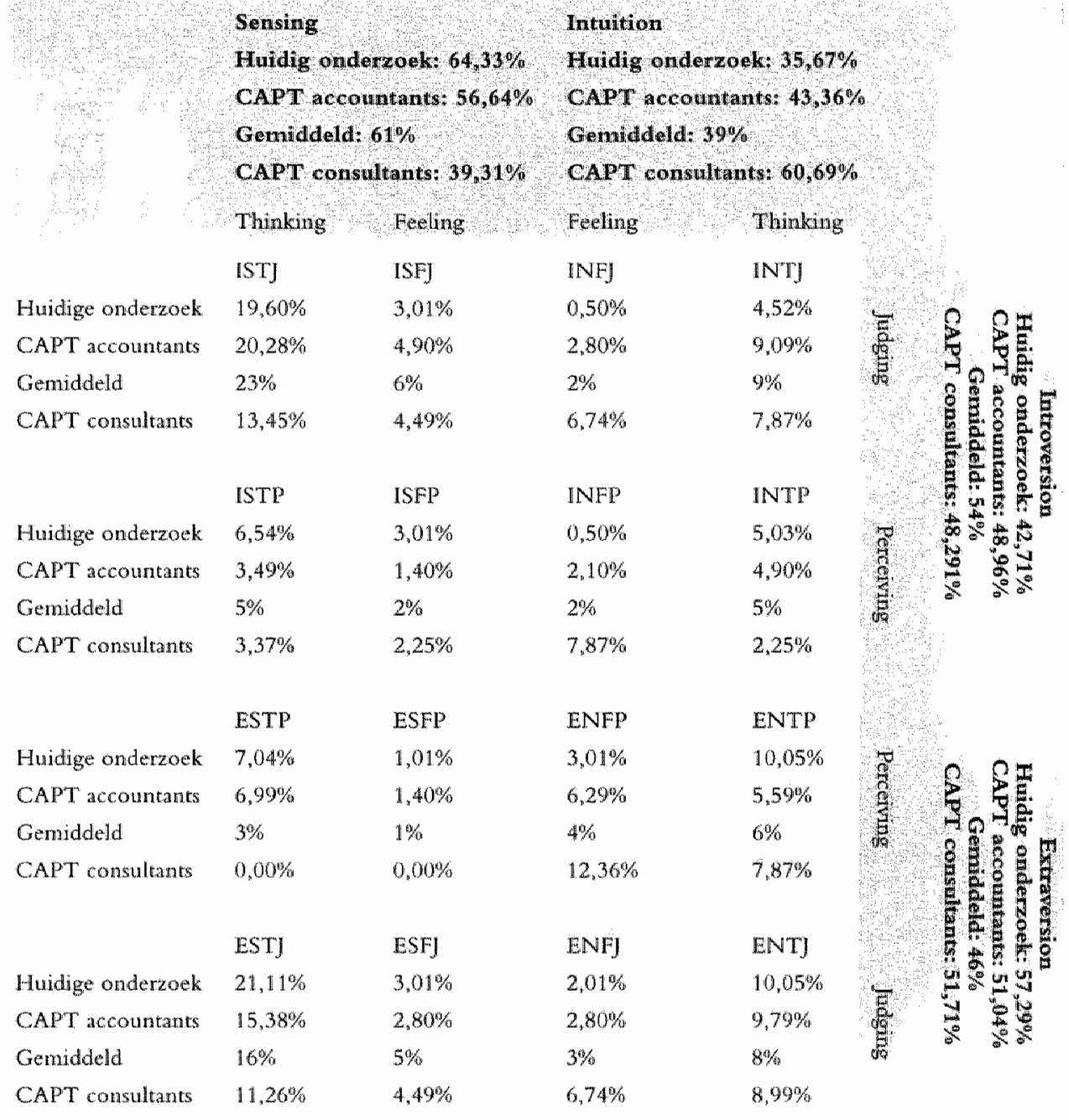


IN DETAIL

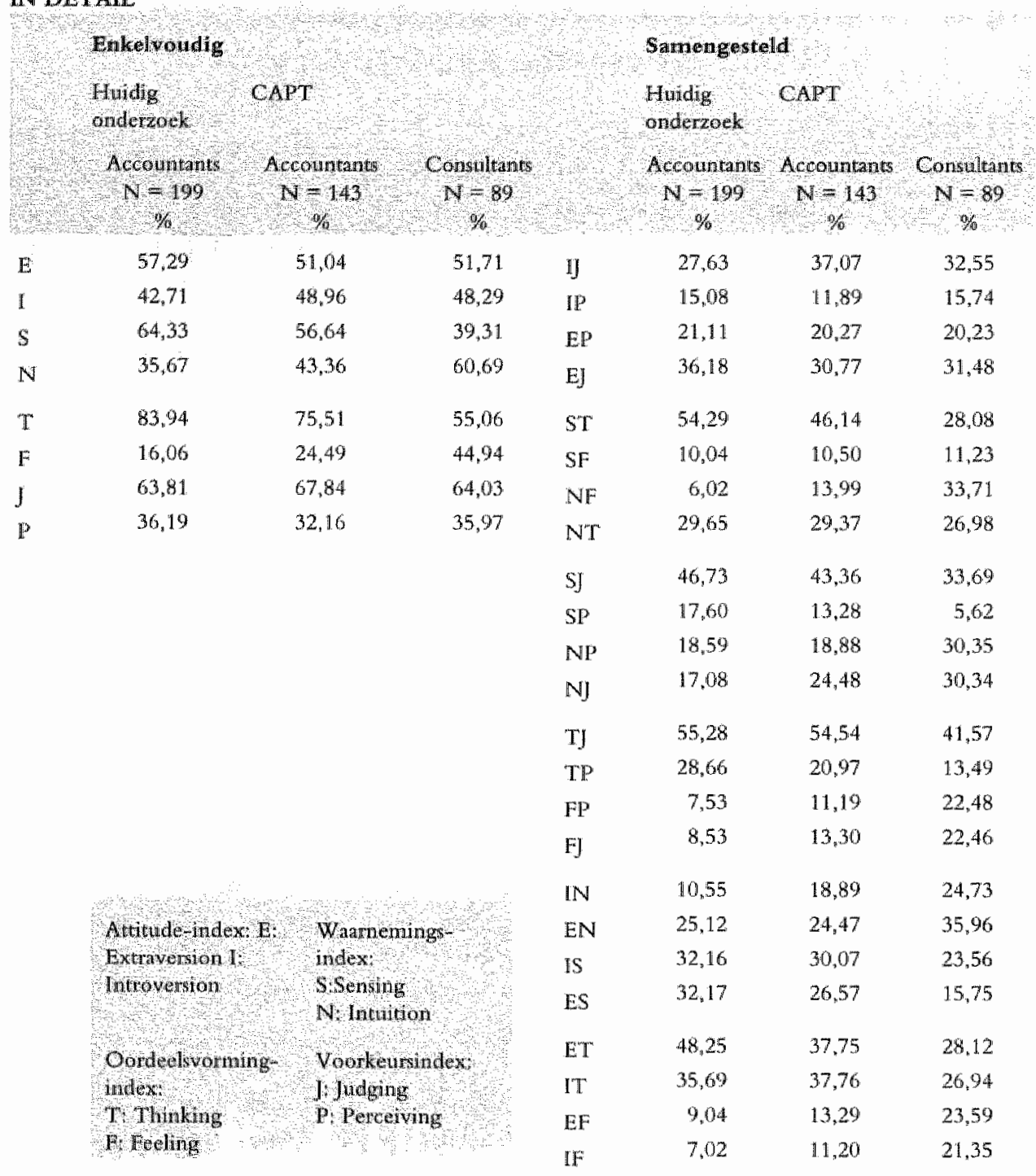




\section{Index figuren}

Figuur 1.1: The Antecedents and Consequences of Knowledge (bron: Libby 1995) . . . . . . . . . . . . . . . . . . . . . . . . . 13

Figuur 1.2: Op administratief-organisatorische processen toegepast model van Libby (naar: Libby 1995) . . . . . . . . . . . . . . . . . 14

Figuur 1.3: Invloed van voorkeur van accountant op waardeoordeel en consensus. . . . . . . . . . . . . . . . . . . . . . . . . . 29

Figuur 2.1: Categorisatie van soorten instructie (bron: Bonner en Walker [1994] en Bonner en Pennington [1991) . . . . . . . . . . . 44

Figuur 2.2: Knowledge matrix (bron: naar Bédard [1994] en Bonner en Pennington [1991]) . . . . . . . . . . . . . . . . 52

Figuur 2.3: Evaluatiecriteria bij het bepalen van professional judgment (bron: naar Solomon en Shields [1995] en Ashton [1983]) . . . . . 56

Figuur 2.4: Karakteristieken van de MBTI indicatoren. . . . . . . . . . . 59

Figuur 2.5: Betekenis van combinaties van waarnemings- en oordeelsvormingindex . . . . . . . . . . . . . . 61

Figuur 3.1: Verdeling accountants over waarnemings- en oordeelsvormingindex combinaties . . . . . . . . . . . . . . . . . . . . 80

Figuur 4.1: Data model . . . . . . . . . . . . . . . . . . 97

Figuur 4.2: Vragenlijsten ....................... 98

Figuur 4.3: Deelprocessen en procedures in het basisprocesmodel . . . . . . 104

Figuur 4.4: Deelprocessen en procedures in het verplichte minimumactiviteitenmodel ...................... 106

Figuur 4.5: Respons casusstellingen door accountants. . . . . . . . . . 108

Figuur 4.6: Responsoverzicht . . . . . . . . . . . . . . . . . . . 109

Figuur 4.7: Ligging en spreiding rangevariabelen . . . . . . . . . 109

Figuur 4.8: Overige beschrijvende variabelen $\ldots \ldots \ldots \ldots \ldots \ldots \ldots \ldots$

Figuur 4.9: Portefeuillevariabelen . . . . . . . . . . . . . . 111

Figuur 4.10: Casusstellingen, opgenomen beheersingsmaatregelen. . . . 112

Figuur 4.11: Aantal ontvangen beoordeelde casusstellingen (totaal 527) en Voorkompercentage $0 \%($ totaal 130) . . . . . . . . . . 113 
Figuur 4.12: Verdeling aantal gegeven verschillende waarderingen bij de 527 beoordelingen . . . . . . . . . . . . . . . . . . 115

Figuur 4.13: Frequentieverdeling gegeven waarderingen ........ 116 Figuur 4.14: Casusstellingen met uiterste oordeel 'Uitstekend' en 'Zeer slecht'

Figuur 4.15: Gegeven waarderingen in aantallen $\ldots \ldots \ldots \ldots \ldots \ldots 118$

Figuur 4.16: Frequentieverdeling gegeven waarderingen per demografische invalshoek ......................... 119

Fïguur 4.17: Procenturele afwijking beoordelingswaarde ten opzichte van totale beoordelingswaarde . . . . . . . . . . . . 120

Figutur 4.18: Spreiding waardeoordelen over castusstellingen met verschillend aantal soorten beheersingsmaatregelen . . . . . . . . . 122

Figuur 4.19: Beoordelingswaarden in totaal . . . . . . . . . . . . 122

Figuur 4.20: Procentuele verloop beoordellingswaarden in totaal . . . . . 122

Figuur 5.1: Hoogste consensuswaarden . . . . . . . . . . . . 131

Figuut 5.2: Procentuele verdeling van de consensuswaarden per casusstelling . . . . . . . . . . . . . . . 132

Figuur 5.3: Consensusindices bij een consensus meetpunt minimaal gelijk

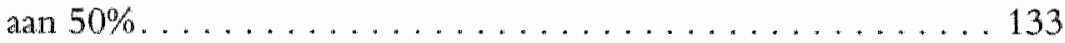

Figuur 5.4: ANOVA bij subselecties 'jaren werkervaring' . . . . . . . . 136

Figuur 5.5: Spearman correlatiecoëfficiënt bij beoordelingswaarde bij subselecties "jaren werkervaring" . . . . . . . . . . . 136

Figuur 5.6: ANOVA bij subselecties 'soort beheersingsmaatregel' . . . . . 140

Figuur 5.7: Spearman correlatiecoëfficiënt bij beoordelingswaarde bij subselecties "soort beheersingsmatregel". . . . . . . . . . . 140

Figuur 5.8: ANOVA bij subselecties "voorkompercentage' . . . . . . . . 143

Figuur 5.9: Spearman correlatiecoëfficiènt bij beoordelingswaarde bij subselecties 'voorkompercentage'. . . . . . . . . . . . . 143

Figuur 5.10: Procentuele verdeling van ranking van de voorkeur en de voorkeurswaarde. . . . . . . . . . . . . . . . 146

Figuur 5.11: Verdeling van de ranking van de voorkeur in aantal . . . . . 147

Figuur 5.12: ANOVA bij subselecties "soort beheersingsmaatregel op eerste dan wel tweede voorkeursplaats'. . . . . . . . . . . 148

Figuur 5.13: Spearman correlatiecoëfficiënt bij subselecties 'soort beheersingsmaatrege op eerste dan wel tweede voorkeursplaats'. 149

Figuur 5.14: Aantal accountants en casusstellingen per subselecties 'combinatie van waarnemingsindex en oordeelswormingindex' . . . . 151

Figuur 5.15: ANOVA bij subselecties 'combinatie van waarnemingsindex en oordeelsvormingindex'. . . . . . . . . . . . . . 153

Figuur 5.16: Spearman correlatiecoëfficiënt bij subselecties 'combinatie van waarnemingsindex en oordeelsvormingindex' . . . . . . . 153 
Figuur 5.17: Verdeling van de ambiguiteitwaarde $\ldots \ldots \ldots \ldots \ldots \ldots 155$

Figuur 5.18: Tolerantiewaarde per ervaringsjaar . . . . . . . . . . 156

Figuur 5.19: ANOVA bij subselecties 'ambiguiteitsgroep' . . . . . . . . . 157

Figuur 5.20: Spearman correlatiecoëfficiënt bij subselecties 'ambiguïteitsgroep" . . . . . . . . . . . . . . . . . 158

Figuur 5.21: Vergelijking beoordelingswaarde bij casusstellingen in relatie tot mate van weerspiegeling . . . . . . . . . . . . 164

Figuur 5.22: Vergeiijking beoordelingswaarde bij casusstellingen in relatie tot voorkeur. . . . . . . . . . . . . . . . . . . 164

Figuur 5.23: ANOVA bij subselecties 'mate van weerspiegeling' ... . . . . 165

Figuur 5.24: Interkwartielafstanden bij box-plot . . . . . . . . . . 166

Figutur 5.25: Verschillen tussen het huidige onderzoek, de CAPT onderzoeken en het gemiddelde. . . . . . . . . . . . 169

Figuur 5.26: Verschillen per enkelvoudige indicator tussen het huidige en het CAPT onderzoek accountants. . . . . . . . . . . . 169

Figuur 5.27: Verschillen per samenstel van indicatoren van het huidige en het CAPT onderzoek accountants. . . . . . . . . . 170

Figuur 6.1: Hypotheses, model van Libby en de oordelen. . . . . . . . 176

Figuur 6.2: Model van Libby, hypotheses en relaties . . . . . . . . . . . . 177

Figuur 6.3: Beantwoording onderzoeksvragen . . . . . . . . . . . 190

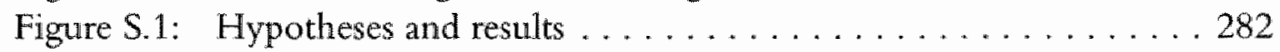

Figure S.2: Answers to research questions . . . . . . . . . 283 


\section{Summary}

\section{S.1. Survey objectives}

This thesis discusses the professional judgment applied by an auditor when reviewing internal control processes. In past decades, studies of auditors' professional judgment have regularly been carried out. The aim of this study is to contribute to international research.

Professional judgment can be viewed from two sides: firstly, from the perspective of the individual auditor and, secondly, from the perspective of the auditing profession. In the case of the individual auditor, we are dealing with the judgment of the professional, while in the case of the auditing profession; we are dealing with the judgment of the profession. It is not only the obvious differences that are important-i.e. the individual versus the group - a relationship also exists between these two perspectives. The quality of the professional opinion formed depends in general on a critical discussion between professional colleagues. While of course the judgment of a professional stems from the mind of that individual professional, the quality of that judgment, which is the subject of critical review by the public, is shaped by his fellow professionals and accumulated in the profession.

The need to understand this professional judgment is a response to society's demand for transparency in the process of forming an audit opinion, which in turn has been prompted in part by recent corporate failures and the discussion on Corporate Governance. On top of this, society can use the information to assess individual auditors and check the quality of the opinions they issue.

Understanding the professional judgment of auditors is equally important for both the auditing profession and the individual auditor. It can help the auditing profession to demonstrate its solid standing and, by implication, that an audit opinion, irrespective of the auditor performing the examination, will not be materially influenced by 
subjective considerations. And when forming his opinion, the individual auditor can be guided by the professional judgment applying within the auditing profession.

Gaining an understanding of the professional judgment of auditors may make it necessary to adapt the educationall curriculum for trainee auditors, in particular to focus more on the key ellements influencing an auditor's professional judgment when reviewing the internal control structure.

Many studies have been carried out in past decades into how auditors reach their opimions, often drawing on research in the field of behavioral sciences relating to decision-making theories and the manner in which people assimilate information. Using the results of these studies into the auditor's opinion-forming process, Libby [1995] developed a generic model based on two functional relationships:

- The quality of an audit opinion is a function of the ability and knowledge of the auditor;

- Knowledge is a function of the ability and experience of the auditor.

The model is therefore based on four variables: ability, experience, knowledge and quality of the audit opinion. These variables should be identified for each specific task. In this survey, the variables are identified as the elements relating to an auditor's review of a specific internal control process.

\section{S.2. The need for an internal control structure}

Regulation of the auditing profession, both nationally and internationally, took shape in the second half of the $20^{\text {th }}$ century. These regulations encompass an enormous range of aspects. When performing his audit examination, the auditor in the Netherlands is committed to observing the auditing standards issued by Koninklijk NIVRA, the Royal Dutch Institute of Registeraccountants [2003]. From the start of his examination, the auditor has to decide on the basis of his findings what subsequent work has to be performed in order to form a sound basis for his opinion. In the risk assessment used for this purpose it is essential that the estimate of the various risk components is as accurate as possible. This is expressly recognized in the applicable auditing standards, which prescribe the following: 'The auditor should obtain an understamding of the accounting and intemal control systews sufficient to plan the audit and develop an effective audit approach.' The more effective the internal control structure in preventing or detecting and resolving material errors in time, the lower the remaining risk that has to be evaluated as part of the audit approach.

The fact that the quality of the internal control structure and procedures impacts the efficiency of the audit has long been recognised, as described by Mock and Turner 
[1999] in their anthology. They refer back to the beginning of the $20^{\text {th }}$ century, when in 1917 Robert H. Montgomery wrote that if the auditor has satisfied himself that the system of intemal check is adequate, he will not atiempt to duplicate work which has been properly performed by someone else'. However, the importance of the internal control structure was not only voiced in 1917. The Sarbanes-Oxley Act that came into force in the US on 25 July 2002 also confirms the importance of 'an adequate internat contro! structure and procedures for financial reporting'.

The significance attached to the internal control structure is also reflected in the expert knowledge requirement imposed on auditors by the IFAC and the recent standard on assurance engagements. The Internal Control Structure is a key subject in the Netherlands, with students following the professional auditing studies, as well as forming a central element in the audit methodologies adopted internationally. Whille each individual auditor in the Netherlands has the same theoretical background, the practical application of this theory is shaped by the audit methodology used by the audit firm concerned and training on the job. Given the emphasis placed on the review of the internal control structure in the standards issued by the audit profession, these various audit methodologies should not differ significantly. Moreover, it can be assumed that the training on the job regarding the review of the internal control structure received by each auditor is also similar.

Accordingly, the internal control structure as a technical field is considered one of the components of the 'common body of knowledge' of the auditing profession.

\section{S.3. Previous research}

A number of theoretical ideas put forward in studies on professional judgment and on the cognitive styles of auditors have been considered. In the years from 1970 to 1990, research on professional judgment focused primarily on the technical aspects of the audit. After 1990, the emphasis shifted to the forming of the audit opinion and Libby [1995] developed his generic model. This model is used in this study to formulate a theoretical assertion on how the auditor reaches an opinion on the quality of a specific internal control process. The process selected for this purpose is the human resources process, which every auditor must review as part of the audit of financial statements.

Professional judgment, and by analogy the quality of the audit opinion based on Libby's model [1995], can be measured by means of effectiveness and efficiency criteria [Davis and Solomon, 1989]. The effectiveness criterion indicates how well an assigned procedure is carried out, while the efficiency criterion looks at the use of 
resources. Much research into auditors' professional judgment in recent years concentrated on effectiveness. This research employed six evaluation criteria, the most common being 'consensus'. Consensus is seen as an alternative criterion for 'accuracy' and is considered a fundamental basis for justifying an opinion, enabling reference to be made to similar opinions given by other professionals. Accordingly, in this study consensus is seen as a proxy for professional judgment.

A large number of studies were also carried out during that period into the cognitive style of auditors. Jung"s theory and the Myers-Briggs Type Indicator were used to categorize the personality characteristics of auditors: the practical completion of an impersonal analysis of observed facts on the basis of technical skills.

\section{S.4. Research questions and hypotheses}

Given the considerable attention devoted to the subject of the internal control structure, the auditor accumulates extensive knowledge in this area. The auditor will draw on this knowledge when forming an opinion on the quality of an internal control process. Uniformity in professional studies and training on the job should in practice lead to identical opinions for similar internal control situations, the so called professional judgment.

Three research questions have been formulated, directed at:

- The "consensus" between auditors" opinions; as a proxy for professional judgment;

- The 'self-insight' of the auditor; as a proxy for the type of internal control procedure that contributes most to the mental prototypical model used as a norm by the audit of internal control procedures;

- Changes in the auditor's personality characteristics.

Professional judgment is more than just the judgment of an individual professional; it represents all opinions given by the total group of individual professionals forming part of a specific profession. This is the view taken in this study, in which professional judgment is described as: the consensus in the opinions formed by individual accountants. The term "professional judgment" is further defined in the question: to what extent do individual auditors issue the same opinion when reviewing similar internal control processes? In other words, what is the degree of consensus in the opinions issued by the individual auditors? By measuring the consensus between these opinions, we can answer the following research question:

( $\mathrm{RQ1}$ ): When reviewing similar intemal control processes, do anditors reach the same opinion? 
In order to answer this first research question, seven hypotheses have been formulated:

- The consensus between the opinions in terms of the adequacy of the internal control processes $(\mathrm{H} 1)$;

- The influence of the number of years of professional audit experience on the consensus between the opinions ( $\mathrm{H} 2)$;

- The influence of the different types of internal control procedures on the consensus between the opinions ( $\mathrm{H} 3 \mathrm{a})$;

- The influence of experience with a certain situation on the consensus between the opinions (H3b);

- The preferences of auditors for internal control procedures $(\mathbb{H} 4)$;

- The influence of the cognitive style of the auditors on the consensus between the opinions (H5a);

- The influence of the auditors' degree of tolerance for ambiguity on the consensus between the opinions ( $\mathrm{H} 5 \mathrm{~b})$.

When designing the internal control structure, management makes a selection from a large number of possible accounting and internal control procedures. This selection is influenced not only by personal preference, but also by the nature of the company.

The auditor, too, develops his own preferred mix of accounting and internal control procedures. When reviewing internal control processes, the auditor systematically relies on his education, experience and instructions in this field. In this way, the auditor develops an understanding of the relative concept of importance and his preference for a particular mix of accounting and internal control procedures. This preference can then influence the auditor's opinion and therefore the consensus.

By classifying the auditors' reviews into various research groups, we can answer the following research question:

(RQ2): Does an auditor's preference for particular internal control procedures influence the consensus between opinions?

In order to answer the second research question, one hypothese have been formulated:

- The influence on the consensus between opinions of the presence of internal control procedures considered by the auditor to be the most important (H6).

Partly in response to public demand, the auditor is devoting increasingly more attention to understanding the operating and internal control processes. When auditing 
the financial statements, he aims to rely on the proper functioning of these processes and the related internal control procedures; and in terms of corporate governance he relies on the quality of these processes. In this way, the auditor becomes an expert in the field of operating and internal control processes.

Based on the results of psychological tests, we can answer the following research question:

(RQ3): Does the psychological profile of the auditors in this study differ from the psychological profile of auditors in other similar studies?

One hypothesis has been formulated for the purpose of answering this third research question:

- The influence of current developments in accountancy on the personality characteristics of the auditor $(\mathrm{H} 7)$.

\section{S.5. The approach}

Three different research tools were used in this study: questionnaires, case studies and psychological tests. The questionnaires, designed to gather demographic and background data, and the case study were developed specifically for this study. The psychological tests were performed using standard questionnaires, in use for many years, based on the Myers-Briggs Type Indicator and the Tolerance for Ambiguity test.

When selecting the internal control process, the aim was to use a process that all auditors would regard as routine and one that is considered separately and in depth during the professional auditing studies. This process has also been used in earlier studies into professional judgment and is one that can be seen in a consistent context: the human resources process. As there is staff employed at all audited companies, every auditor has to review the human resources process during his audit.

The case study is based on a general model. The case studies presented to the auditors took the form of one of 32 variations, based on different combinations of five types of internal control procedures.

This study can be typified as an explanatory comparative survey performed at a single point in time. This entails analyzing a large volume of data gathered from individual auditors at one particular point in time to try to understand the two concepts: professional judgment and personality characteristics. 
The following criteria were used for selecting the auditors included in the survey:

- Registered with Royal NIVRA as having successfully completed the Internal Control Structure study; and

- Working as a public auditor; and

- Working in the Netherlands.

A total of 784 auditors, representing $20 \%$ of the total population, were selected at random. In total, 199 auditors responded to the request to participate in the survey. Of this group, all 199 auditors took part in psychological tests; 187 anditors indicated their preference for a particular internal control procedure. 195 auditors assessed a total of 527 case studies, spread over the 32 variants. In each case, the auditor was asked to award a score on a seven-point scale from 'Excellent' to 'Very poor'.

Based on an initial analysis of the assessments of the case studies, it can be concluded that:

- At least three and at most six of the seven possible scores were awarded to each case study;

- For 23 of the 32 case studies, five or six different scores were awarded; this represents 367 of the 527 case study assessments;

- For 29 of the 32 case studies, scores of 'Very good', 'Good' and 'Sufficient' were given;

- At least one score of 'Good' was given for all case studies;

- $80 \%$ of all case study assessments was given a positive score;

- The highest score 'Excellent' was awarded to 19 of the 32 case studies; the lowest score 'Very poor' was only given on one case study.

\section{S.6. Conclusion to research questions}

Of the nine hypotheses (including the sub-hypotheses), a positive result was established for two of the sub-hypotheses relating to the type of internal control procedure ( $\mathrm{H} 3 \mathrm{a}$ and $\mathrm{H} 4)$. The type of internal control procedure included in an intemal control process did not influence the consensus between the auditors' opinions (H3a). In addition, auditors do not have preferences for internal control procedures (H.4).

No conclusive result was reached for the remaining (sub-) hypotheses. The results of the various assertions for each research question are set out in figure S.1.

The results of the separate assertions as set out in figure S.1, and in particular the diversity of opinions given, formed the basis for answering the research questions. 


\section{Hypothesit Resalt}

RQ1: consenstus between auditors' opinions

H1 There is consensis bewwet aditors opinions in serms of the adequacy of the Wo interrall concrol processes.

H2 An increase in the number of years of professional audic experience has a posi- No tive influence on the consensus berween auditors" opirions.

H3. Not the type of interna control procedure included in the internal control Yes process reviewed but the number of different types has influence on the consensus berween atuditors' opinions.

H3b Aciditors wh an equal level of expentence with a specific interral control No procedure will thave more consensus betweer their opinions.

H4 Auditors do not have preferences for internal control procedures Yes

H5a There will be more consensuses anong auditors belonging to the same MBTT No category.

$15 b$

There will be more consensus among auditors belongung to the same Toler- No ance for Ambiguty caregory.

RQ2: the auditor's 'self-insight"

H6

Auditors with an equal level of importance with respect to a specific internal No control procedure will have more consensuses between their opinions.

RQ3: changes in the auditor's personality characteristics

H7

Currert developments in accountancy have influenced the personality charac- No teristics of auditors.

Figure S.1: Hypotheses and results

The first research question (RQ1) could not be answered positively. The wide range of answers given meant that consensus between the auditors' opinions could not be proved.

The second research question (RQ2) could not be answered positively. It was shown that an auditor's preference for a set of internal control procedures had a positive influence on his opinion. However, the results did not show that this preference had an influence on the consensus between auditors' opinions.

The third research question (RQ3) could not be answered positively. Auditors seem to continue to fall into the same cognitive style category.

The answers to the research questions are set out in figure S.2. 


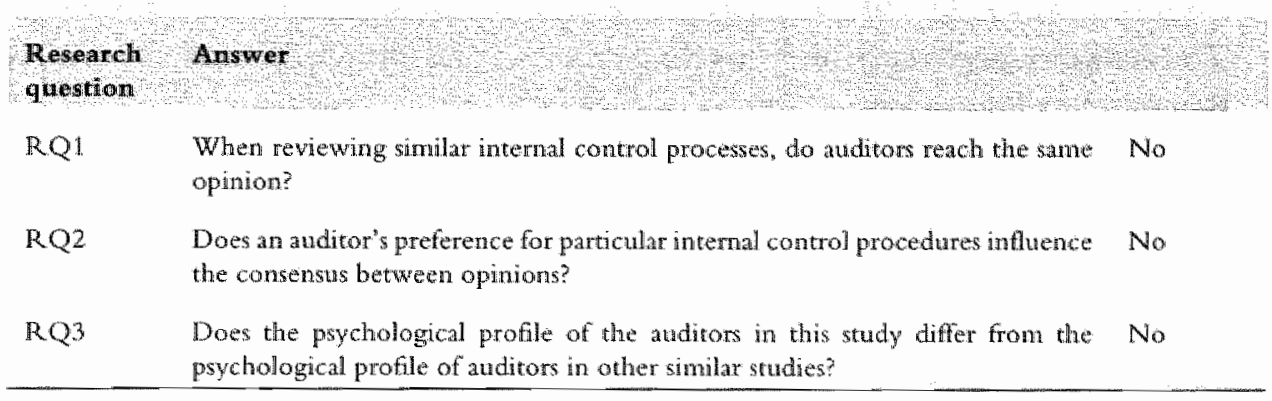

Figure S.2: Answers to research questions

Given the conclusion regarding the theoretical basis allowing the auditor to evolve into a professional, it is more appropriate to speak of the judgment of an individual professional than of professional judgment. This is not conducive to the intended transparency in the process of forming an audit opinion on the review of the control of operating processes. Moreover, the opportunity to develop and adopt an objective review framework geared towards the efficiency of the audit procedures of the individual auditor for auditing the financial statements has not been taken.

\section{S.7. Future research}

The auditing profession, under pressure from social developments and the demand for more transparency, will profit from demonstrating its professional judgment. This professional judgment can be evidenced by the consensus of auditors" opinions in similar situations. Moreover, if this professional judgment is translated into prototype models, the public will be able to validate the auditors' opinions against the standards formed by these models. The auditors can then increase the transparency of their decision-making by applying these standard models, thereby providing society with a greater understanding of the reasons underlying the opinions given.

To this end, future research should be carried out directed at:

- The influence of the audit profession on the development of procedural knowledge;

- The influence of an opinion on an operating process on subsequent audit procedures;

- The manner in which the theoretical components of the auditor"s study are translated into a practical approach to the problem;

- The extent to which partners of an audit firm are seen as role models for the more junior staff and the impact of this on their judgment and their decision-making; 
- The auditor's 'preference' for operating processes and knowledge domains which he considers important;

- The correlation between the degree of "preference' and the auditor's experience;

- Changes in the type of cognitive style during:

- Studies to complete the theoretical part of the professional education;

- The practical traineeship;

- Permanent education;

- The influence of new audit methodologies on cognitive style;

- Change flexibility measured as the time-span between the implementation of a major change in the audit approach and the actual change in the auditor's personality characteristics. 


\section{Curriculum Vitae}

J.P.J. (Hans) Verkruijsse RE RA is partner bij Ernst \& Young Accountants. In die hoedanigheid is hij fulltime verbonden aan het Directoraat Vaktechniek en verantwoordelijk voor de sectie Assurance Services. Tevens is hij Universitair Hoofddocent aan de Universiteit Maastricht alwaar hij doceert in de vakken bestuurlijke informatievoorziening en epd-auditing. Hij heeft diverse publicaties op zijn naam staan op het gebied van accountancy en edp-auditing.

Hij is onder meer voorzitter van de Commissie Controlevraagstukken en Richtlijnen van het Koninklijk NIVRA, voorzitter van de Raad van de Beroepsethiek van de NOREA, lid van de Education Committee van het International Federation of Accountants en lid van de Assurance Working Group van XBRL International. Hij participeert in ISAR/UNCTAD vergaderingen met betrekking tot onderwijs en corporate governance en was technical advisor bij de International Auditing and Assurance Standards Board van het IFAC.

J.P.J. (Hans) Verkruijsse RE RA is a partner at Ernst \& Young Accountants in the Netherlands where he is responsible for the Practice Performance Department section Assurance Services. He also holds a position as an associate professor in Accounting Information Systems, Business Process Analysis and Information System Auditing at the University Maastricht. Hans is qualified as Dutch CPA ("RegisterAccountant") and qualified as Information Systems Auditor ("Register Edp-auditor"). Hans has published many articles in the area of accountancy and edp-auditing.

In addition among others, Hans holds the following positions: as chairman of the Dutch Auditing and Assurance Standards Board of the Royal NIVRA, the Dutch Institute of CPA's; as chairman of the Ethical Committee of the NOREA, the Dutch Institute of Information Systems Auditors; as member of the Education Committee of the International Federation of Accountants and as member of the Assurance Working Group of XBRL International. He also participates in the ISAR/ UNCTAD meetings related to education and corporate governance and was a Technical Advisor of the International Auditing and Assurance Standards Board ofIFAC. 